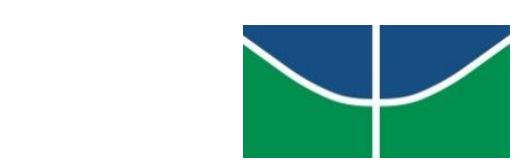

UNIVERSIDADE DE BRASÍLIA - UNB

INSTITUTO DE LETRAS - IL

DEPTO. DE LINGUÍSTICA, PORTUGUÊS E LÍNGUAS CLÁSSICAS - LIP PROGRAMA DE PÓS-GRADUAÇÃO EM LINGUÍSTICA - PPGL

ELEMENTOS FUNDAMENTAIS DA GRAMÁTICA LAKLÃNÕ 


\section{NAMBLÁ GAKRAN}

\section{ELEMENTOS FUNDAMENTAIS DA GRAMÁTICA LAKLÃNÕ}

Tese apresentada ao Curso de Doutorado em Linguística do Programa de Pós-Graduação em Linguística do Instituto de Letras da Universidade de Brasília, como requisito parcial à obtenção do título de Doutor em Linguística.

Orientadora: Profa. Dra. Ana Suelly Arruda Câmara Cabral. 


\title{
ELEMENTOS FUNDAMENTAIS DA GRAMÁTICA LAKLÃNÕ
}

\begin{abstract}
Esta tese foi julgada adequada à obtenção do título de Doutor em Linguística e aprovada em sua forma final pelo Curso de Doutorado em Linguística, do Programa de Pós-Graduação em Linguística do Instituto de Letras da Universidade de Brasília.
\end{abstract}

Brasília, 28 de maio de 2015

Dra. Ana Suelly Arruda Câmara Cabral, Dra. (Presidente)

Universidade de Brasília

\author{
Greg Urban, Dr. (Membro externo) \\ Arthur Hobson Quinn Professor of Anthropology, Interim Department Chair \\ University of Pennsylvania
}

Prof. Maxwell Miranda, Dr. (Membro externo)

Universidade Federal do Mato Grosso

Prof. Fábio Bonfim Duarte, Dr. (Membro externo)

Universidade Federal da Grande Dourados

Profa. Rozana Reigota Naves, Dra. (Membro interno)

Universidade de Brasília

Prof. Andérbio Márcio Silva Martins, Dr. (Suplente)

Universidade Federal da Grande Dourados 
Para Me chamam de 'indio'...

Porque não me chamár de 'Laklãnõ'?

Se quiser, pode me chamar de 'clã' do 'sol',

Mas se preferir, me chame de povo rápido, que conhece todos os cantos da terra.

E porque não gente do sol ou ligeiro?

Ou me chame de 'o que emergiu da água e da montanha'.

Ciência tenho das histórias vividas, do lançar das flechas, minha flecha não emperra.

Sei da lança toda a manha, da ponta sei como fere;

Posso errar pelas veredas, mas minhas fúrias não erram.

Sei as táticas do ataque, sei estratégias de guerrear;

Sozinho no meio do 'ẽn kuty', nunca, jamais me embrenho;

Jamais estalo um graveto, sem que os olhos nos pés eu não tenha; serpenteio meu corpo por

entre os rios e mangues, por entre águas e lamas, por entre chagas e danças.

Conheço a seiva das terras, dos bichos sei todas as manhas.

Enfrento as feras das matas, as conhecidas e as estramhas.

É... não adianta podar minhas folhas e tentar silenciar a minha história, pois somente

afogará as minhas crenças e, assim, reanimará minha raiz.

Não se seca raiz de quem tem sementes espalhadas pela terra para brotar.

Não se apaga dos nossos avós as ricas memórias;

Não se apara largas asas, porque o céu é liberdade e a fé é encontrar o 'Ãgglẽñe’ um dia.

Autor: Nanblá Gakran 


\section{AGRADECIMENTOS}

Um trabalho acadêmico é resultado de muitos esforços, aliados a incentivos, preocupações, apoio, sugestões, estímulos, conselhos e confiança de muitas pessoas. Dessa forma, eu quero agradecer às pessoas que, de uma forma ou outra, trilharam comigo esta minha jornada até aqui.

Inicialmente quero agradecer a Deus, pela graça, força, coragem e principalmente pela vida que Ele me deu até o dia de hoje, para assim poder escrever e registrar a língua materna do meu povo Xokleng/Laklãnõ, a qual Ele nós deu.

Da mesma forrma agradeço de coração à minha querida orientadora, professora Dr $^{\mathrm{a}}$ Ana Suelly Arruda Câmara Cabral, em fornecer-me ajuda, pelos ensinamentos através do crescente aperfeiçoamento de meu trabalho, paciência, serenidade, competência e amizade.

Em especial aos meus três queridos filhos, Kuzug, Txulin e Txulunh, por compreenderem a razão do por quê da minha ausência durante período tão longo. A minha conquista e, portanto deles também. Para minha querida mãe Conheco Namblá, quero expressar toda minha gratidão pela sua generosidade, carinho, compreensão, estímulo e exemplo. O meu carinho vai também para todos os meus irmãos, sobrinhos e para toda a família Gakran.

Ao meu querido e saudoso pai, Kuzung Gakran e aos meus inesquecíveis avós, Kãnhãhá e Nãg, que na sua simplicidade sempre me incentivaram para manter vivas as histórias dos nossos ancestrais e a língua materna, quando eram mais jovens. Seus ensinamentos vivem em minha memória e em meu coração.

Aos colegas de curso e do LALLI - 'Laboratório de Línguas e Literaturas Indígenas', pelo companheirismo e amizade. Em especial uma grande amiga e companheira, Suseile Andrade Sousa (Suzi) que sempre me ajudou em todos os aspectos, quando precisava.

Dos meus colegas, quero agradecer, em especial, ao Dr. Joaquin Paulo de Lima Kaxinawá e ao Dr. Aisanain Paltú Kamaiurá, que trilharam junto comigo a difícil caminhada em busca de um doutoramento. 
Ao casal Fabio Pereira Couto, Michela Ribeiro Barbosa e seu filho Arthur, que Deus colocou no meu caminho. Não tenho palavra para agradecer este casal, que sempre me ajudou em todos os aspectos, sempre que precisei deles.

Ao casal Mauro Luiz Carvalho e Vilma Benedito de Oliveira, amigos que Deus colocou no meu caminho, quando cheguei em Brasília e que também sempre me ajudou nas horas em que deles necessitei.

A minha grande amiga Kassilier Lopes (Socorro), que sempre me ajudou durante estes quatros anos em Brasília.

Ao grande amigo 'Kokama' 'Maurício Cordeiro de Souza', pela sua amizade e componherismo durante o tempo que compartilhamos moradia e estudos. Em especial ao grande amigo André Luís Arena Caetano, de Recife, que mesmo distante torceu pelo meu sucesso. Ao grande amigo Gabriel de Oliveira pela ajuda acadêmica sempre que precisei. Ao grande amigo Guaraim Liberato Jr., pelo seu apoio como pessoa em todos os sentidos, desde o início da minha caminhada, do vestibular ao ingresso na graduação até concluir o doutorado.

Agradeço ao grande amigo e colega, professor Dr. Ernesto Jacob Keim, pelo seu apoio como pessoa, pelo seu incentivo na minha caminhada no Mestrado e no Doutorado. Ao grande amigo, Dr. Othon Henry Leonardos pela sua amizade e apoio quando mais precisei. A todos os professores, docentes do curso, que trilharam junto comigo o caminho dos estudos.

Aos demais amigos e amigas, simpatizantes das causas indígenas, que acreditaram em mim, e que de um modo ou outro me apoiaram.

A todo o povo Xokleng/Laklãnõ pelo seu apoio direto e indireto e também pela confiança que depositada na minha pessoa. Em especial a todas as pessoas que contribuíram com as informações para que este trabalho pudesse se concretizar.

Também expresso aqui o meu agradecimento à CAPES - 'Coordenação de Aperfeiçoamento de Pessoal de Nível Superior', por depositar confiança na minha pessoa, fornecendo-me uma bolsa de estudos que garantiu a realização do meu doutoramento.

E por fim, quero agradecer a querida Joana Vangelista Mongelo, pelo companheirismo, constante apoio, sempre com uma palavra amiga nos momentos mais difíceis da minha caminhada.

A todos, o meu muito obrigado. 


\section{RESUMO}

A presente tese consiste em uma descrição de aspectos fundamentais da gramática Laklãnõ. Sua preocupação maior é a morfologia e a morfossintaxe da língua, embora apresente um breve estudo sobre a fonologia segmental. Trata-se de estudo pioneiro sobre as classes de palavras do Laklãnõ, focalizando todas as classes de palavras identificadas na língua, assim como tipos de predicados, tipos de orações, combinações de orações por coordenação e por subordinação. Um capítulo é dedicado ao sistema de alinhamento, intrinsecamente relacionado às expressões de aspecto. Descreve as expressões de aspecto e modalidade na língua, aborda a negação e os tipos de perguntas existentes. Oferece um foco especial à descrição de aspectos semânticos de palavras, particularmente, verbos. A presente tese associa uma descrição linguística à ideia de que a língua é um sistema, constituído de subsistemas dinamicamente interconectados, e funciona como uma ferramenta cultural fundamental para a comunicação humana (cf. SAPIR, 1949; JOURDAN \& EVERETT, 2008, 2012). Foram considerados os estudos linguísticos sobre o Laklãnõ por Wissemann (1968), Gakran (2005) e Urban (1985), assim como estudos sobre outras línguas Jê, como os de Miranda (2014), Silva (2003) e Ferreira (2001). As principais referências teóricas foram Guéntcheva (2011) sobre aspecto, Dixon (1994) e Comrie (1987) sobre alinhamento, Schachter (1985) e Vogel e Comrie (2000) sobre classes de palavras e Grinevald (2002) sobre classificadores.

Palavras-chave: Língua Laklãnõ. Família Jê meridional. Descrição gramatical. Classes de palavras. Sintaxe e morfossintaxe. Alinhamento. Aspecto e modalidade. 


\begin{abstract}
The present dissertation is a description of fundamental aspects of the Laklãnõ grammar. Its main concern is the morphology and the morphosyntax of the language, although it also presents a brief study of Laklãnõ segmental phonology. It is a pioneer study of Laklãnõ word classes, describing all word categories identified in the language, as well as types of predicates, clauses and combination of clauses either by coordination or by subordination. A whole chapter is dedicated to the alignment system of the language, which is intrinsically related to the expressions of aspect, which are also described, as well as modality, negation, and od questions. It focuses on the semantic aspects of words, especially of verbs and postpositions. This research associates a linguistic description to the idea that a language is a system constituted by subsystems intrinsically and dynamically interconnected, and it follows the idea that language is a cultural and fundamental tool to human communication (cf. SAPIR, 1949; JOURDAN \&EVERETT, 2008 e 2012). This dissertation considered previous linguistic studies on the Laklãnõ language by Wissemann (1968), Gakran (2005), Urban (1985), as well as studies on other Jê languages (cf. MIRANDA, 2014; SILVA, 2003; FERREIRA, 2001). Its main theoretical references are Guéntcheva (2011), on the study of Laklãnõ expressions of aspect, Dixon (1994), and Comrie (1987), on Laklãnõ alignment systems, Schachter (1985), Vogel and Comrie (2000), on word classes, and Grinevald (2002), on noun classifiers.
\end{abstract}

Keywords: Language Laklanõ. Southerly Ge family. Grammatical description. Word classes. Syntax and morphosyntax. Alignment. Aspect and modality. 


\section{LISTA DE FIGURAS}

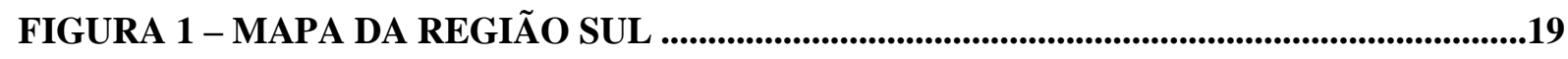

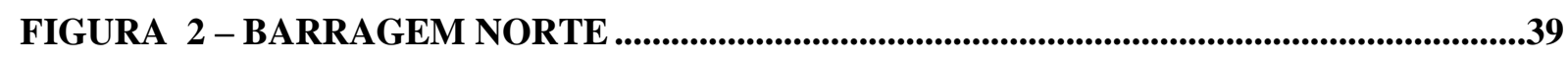

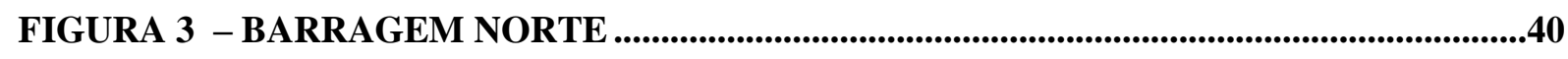

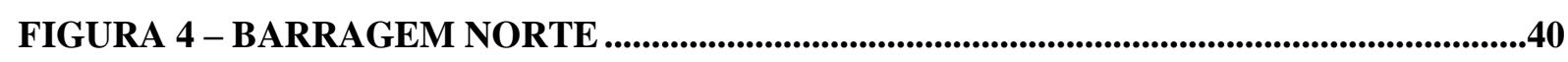

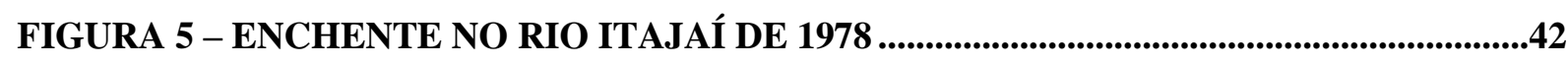

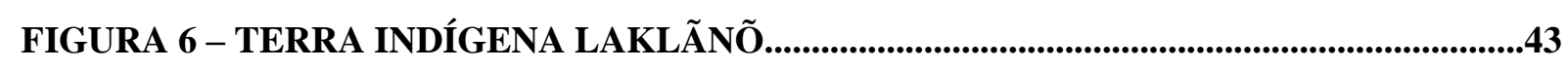


QUADRO 1 - DOS FONEMAS CONSONANTAIS...............................................................56

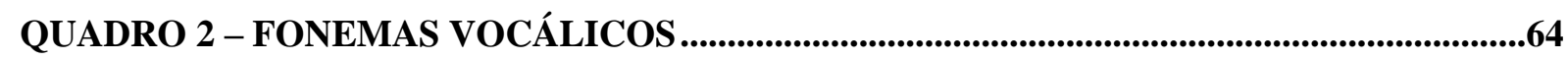

QUADRO 3 - CORRESPONDÊNCIAS DOS FONEMAS X GRAFEMAS - CONSOANTES..70

QUADRO 4 - CORRESPONDÊNCIAS DOS FONEMAS X GRAFEMAS - VOGAIS..............71

QUADRO 5 - PRONOMES DO CONJUNTO 2...................................................................74

QUADRO 6 - OS TRÊS ESTADOS DE EXISTÊNCIA DOS REFERENTES DOS NOMES.....98

QUADRO 7 - NOMES MASCULINOS E FEMININOS............................................................100

QUADRO 8 - VERBOS POSICIONAIS COM SUAS FORMAS SINGULARES E PLURAIS 155 QUADRO 9 - VERBOS TRANSITIVOS E UM CONJUNTO DE INTRANSITIVOS ...............156

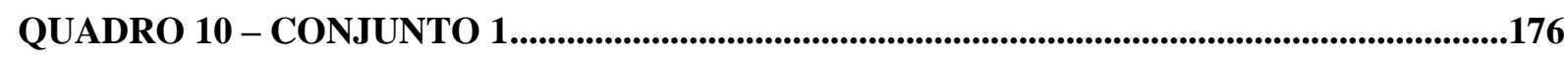

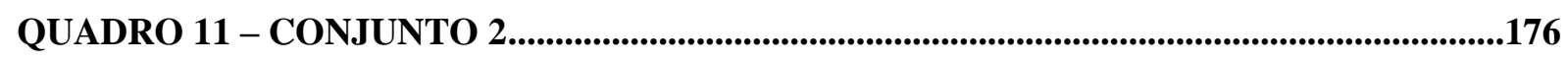

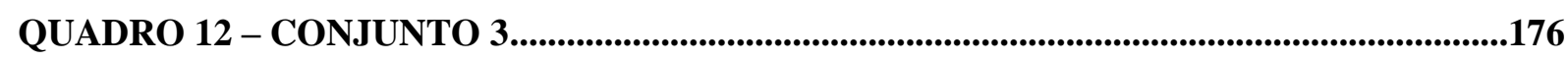

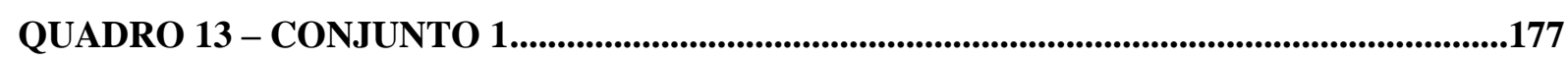

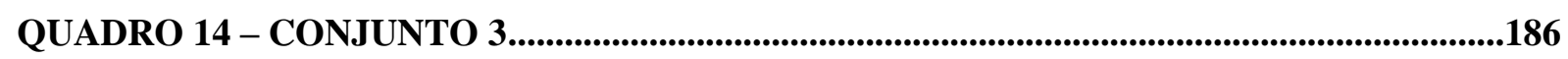

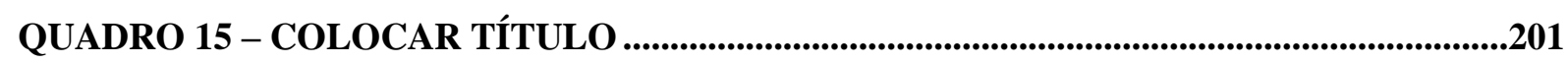


LISTA DE SIGLAS E ABREVIATURAS

\begin{tabular}{|c|c|c|}
\hline 1 & - & PRIMEIRA PESSOA DO SINGULAR \\
\hline 1P & - & PRIMEIRA PESSOA DO PLURAL \\
\hline 2 & - & PRIMEIRA PESSOA DO SINGULAR \\
\hline $2 \mathrm{P}$ & - & SEGUNDA PESSOA DO PLURAL \\
\hline $3 \mathrm{M}$ & - & 3 PESSOA DO SINGULAR \\
\hline $3 \mathrm{~F}$ & - & 3 PESSOA DO SINGULAR FEMININO \\
\hline $3 \mathrm{P}$ & - & 3 PESSOA DO PLURAL \\
\hline AUX.1 & - & VERBO AUXILIAR ESTAR EM PÉ \\
\hline AUX. 2 & - & VERBO AUXILIAR ESTAR SENTADO \\
\hline AUX.3 & - & VERBO AUXILIAR ESTAR DEITADO \\
\hline $\mathrm{CF}$ & - & CONJUNÇÃO CONECTIVA \\
\hline CONTR & - & CONTRÁRIO \\
\hline CORR & - & TERCEIRA EPSSOA CORREFERENCIAL \\
\hline DEM & - & DEMONSTRATIVO \\
\hline ENF & - & ENFÁTICO \\
\hline ESTAT & - & ASPECTO ESTATIVO \\
\hline ESPEC & - & ESPECIFICADOR \\
\hline $\mathrm{F}$ & - & FEMININO \\
\hline IMPERF & - & IMPERFECTIVO \\
\hline INTERR & - & INTERROGATICO \\
\hline M & - & MASCULINO \\
\hline MG & - & MARCA DE GÊNERO \\
\hline MS & - & MARCA DE SUJEITO \\
\hline NEG & - & NEGAÇÃO \\
\hline NOM & - & NOMINALIZADOR \\
\hline POSP & - & PosPOSIÇÃO \\
\hline PERF & - & ASPECTO PERFECTIVO \\
\hline PL & - & PluRAL \\
\hline PROGR & - & ASPECTO PROGRESSIVO \\
\hline PROSP & - & ASPECTO NOMINAL PROSPECTIVO \\
\hline
\end{tabular}


RELACIONAL

RETR - $\quad$ ASPECTO NOMINAL RETROSPECTIVO

SIMIL $\quad-\quad$ SIMILITIVO

TRANS - $\quad$ TRANSLATIVO 


\section{SUMÁRIO}

1. INTRODUÇÃO ..............................................................................................................................14

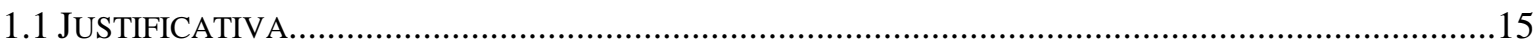

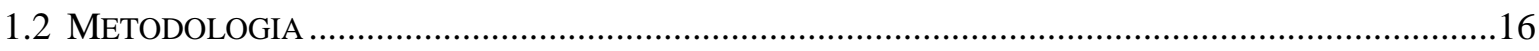

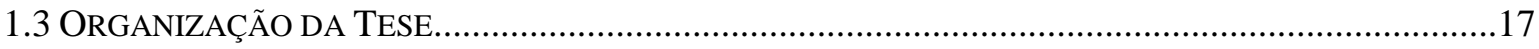

\section{CAPÍTULO I - UM POUCO DA HISTÓRIA DA SITUAÇÃO DOS POVOS INDÍGENAS NO}

BRASIL..........................................................................................................................................................18

1.1 PRELIMINARES ……………………………………………………………………....18

1.2 O POVO XOKLENG ……………………………………………………………………19

1.2.1 Território e Histórico dos Xokleng.........................................................................................19

1.2.2 História do nome Xokleng e seus sentidos .........................................................................23

1.2.3 Autodenominação atual .................................................................................................24

1.2.4 O meio ambiente e a espiritualidade na fala do laklãnõ/Xokleng .........................................26

1.2.4.1 O ritual de iniciação das crianças................................................................................26

1.2.4.2 Espaço e espiritualidade dos Laklãnõ/Xokleng.............................................................27

1.2.4.3 A relação com a natureza e a espiritualidade ...............................................................32

1.2.4.4 Elementos da geração, criação e transformação Laklãnõ em animais ............................34

1.3 HISTÓRIA DE CONTATO DOS LAKLÃNÕ/XOKLENG COM OS NÃO ÍNDIOS.........................................36

1.3.1 Localização da terra indígena do povo Laklãnõ/Xokleng e suas organização atual..............37

1.3.2 Mudanças históricas do povo Laklãnõ/Xokleng pela Barragem Norte ..................................39

1.4 HISTÓRIA DA EDUCAÇÃo ESCOLAR ENTRE OS LAKLÃNõ ………………………………………...4

1.4.1 Primeira escola entre o povo Laklãnõ/Xokleng................................................................46

1.4.2 Memória dos alunos da primeira escola entre os Xokleng, na década de 30.........................47

1.4.3 Educação escolar entre os Laklãnõ/Xokleng no período de 1990 até 2015 ..........................52

1.4.4 Preocupação do povo Laklãnõ para recuperar seus costumes ................................................53

CAPÍTULO II - FONEMAS E ORTOGRAFIA DA LÍNGUA LAKLÃNÕ/XOKLENG ...............55

2.PRELIMINARES...............................................................................................................55

2.2 OS FONEMAS VOCÁLICOS …………………………………………………………...64

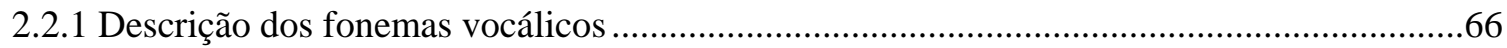

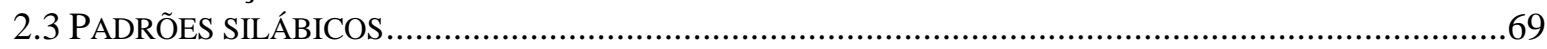

2.4 RESTRIÇÕES FONOTÁTICAS ……………………………………………………………....69

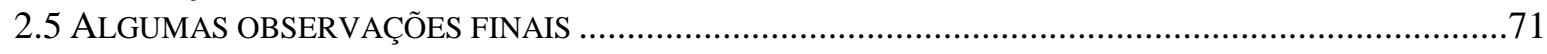

CAPÍTULO III - CLASSES DE PALAVRAS ..................................................................................72

3. PRELIMINARES...............................................................................................................72

3.1SUBSTANTIVOS, OU MAIS BEM PROPRIAMENTE NOMES …………………………………......72

3.1.1 Subclasses de nomes....................................................................................................73

3.2 OS SIGNIFICADOS LEXICAIS DOS NOMES RELATIVOS E ABSOLUTOS …………………………....73

3.2.1 Nomes relativos da subclasse 1 .................................................................................

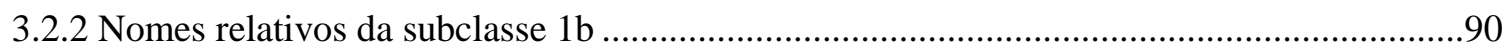

3.2.3 Nomes da subclasse 2 2..............................................................................................95

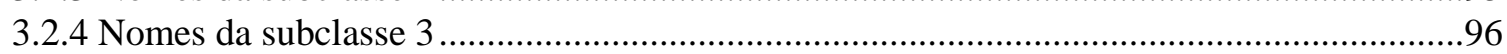

3.2.5 Estado de existência dos referentes dos nomes ..................................................................97

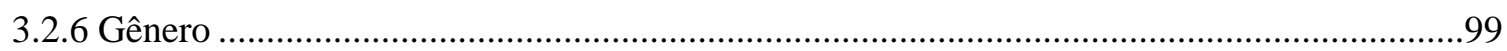

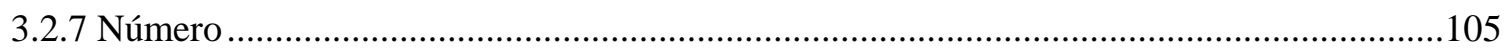

3.2.8 Nomes de quantidade ……………………………………………………………106

3.3.9 Demonstrativos ............................................................................................................107

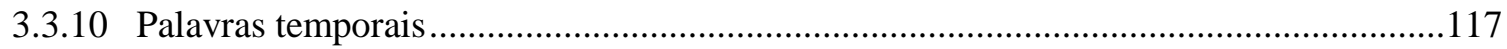




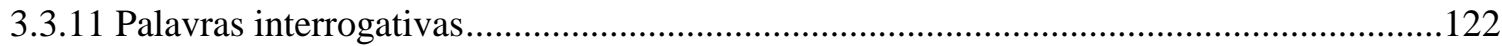

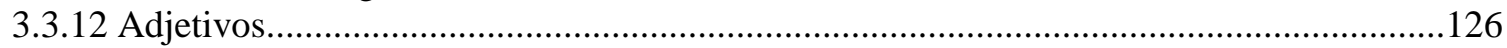

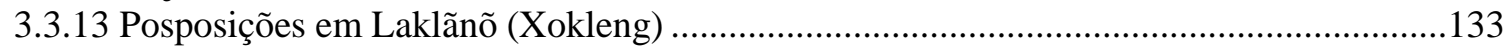

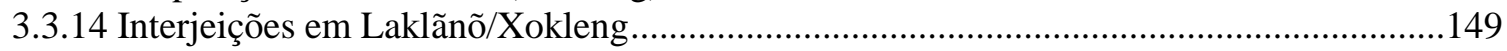

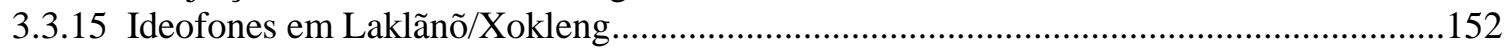

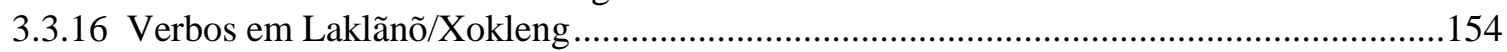

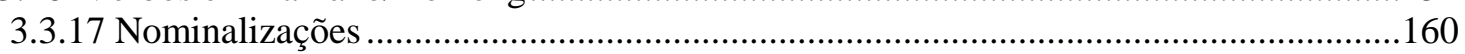

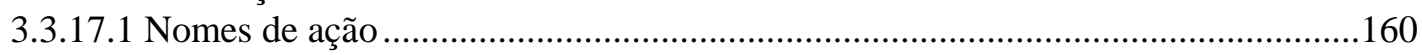

CAPÍTULO 4 - PREDICADOS EM LAKLÃNÕ/XOKLENG .................................................162

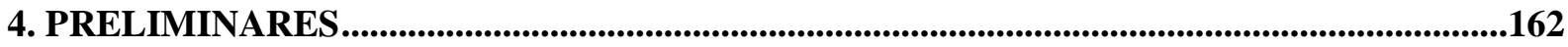

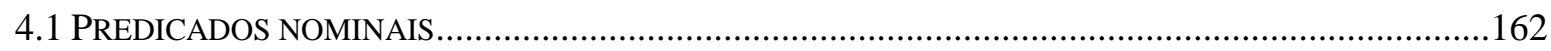

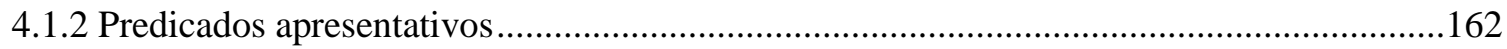

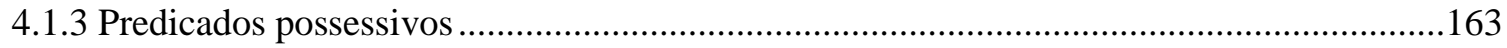

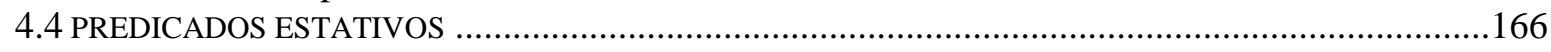

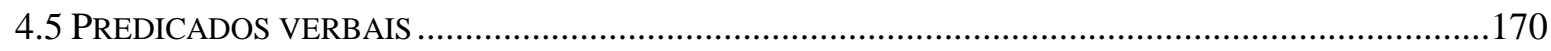

CAPÍTULO 5 - ALINHAMENTO EM LAKLÃNÕ .........................................................................175

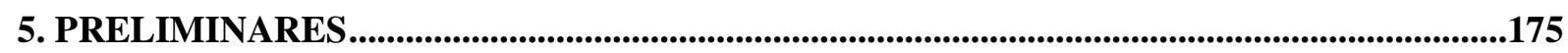

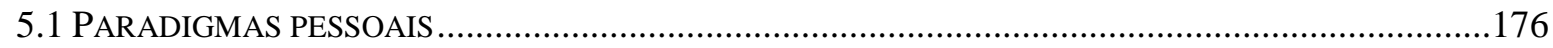

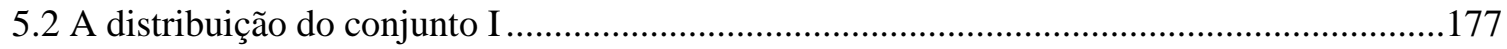

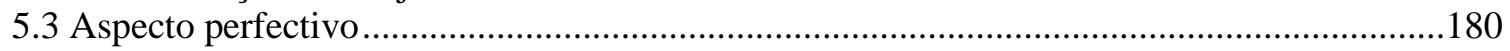

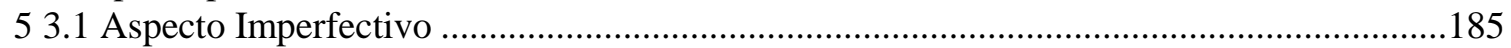

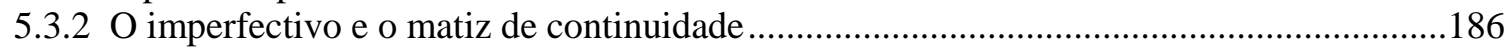

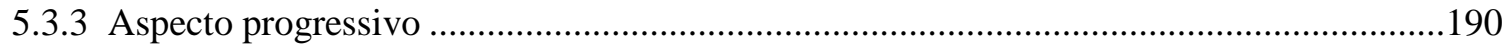

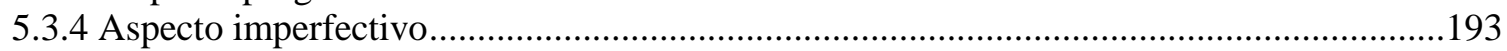

5.4 CONSTRUÇÕES COM O VERBO QUERER SEM ASPECTO NOMINAL …........................................197

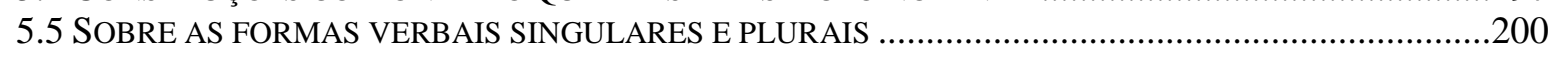

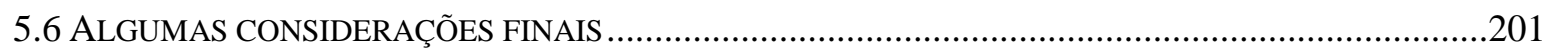

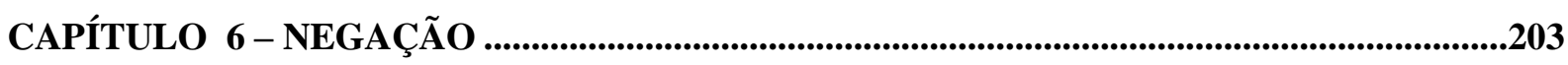

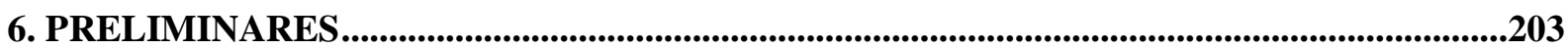

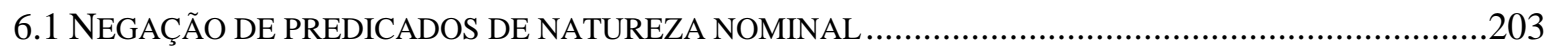

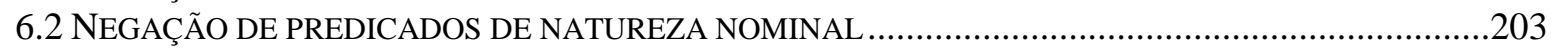

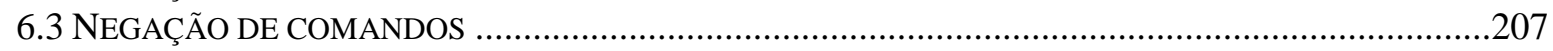

CAPÍTULO 7 - ORAÇÕES INTEROGATIVAS EM LAKLÃNÕ ...............................................210

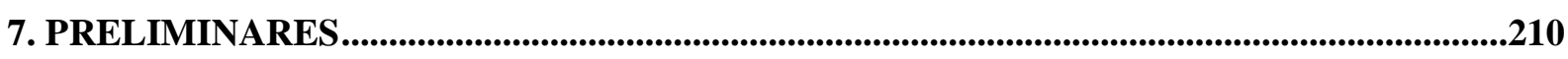

CAPÍTULO 8 - ORAÇÕES DE COMANDO .................................................................................222

CAPÍTULO 9 - CONSTRUÇÕES COMPARATIVAS ..........................................................226

CAPÍTULO 10 - COORDENACÃO E SUBORDINACÃO .....................................................2322

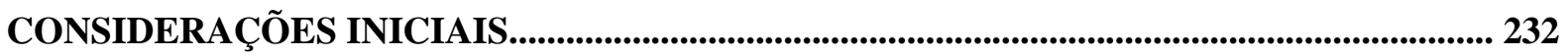

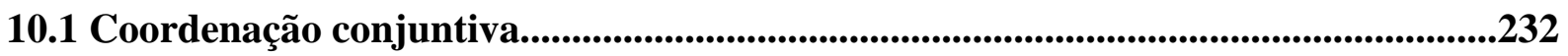

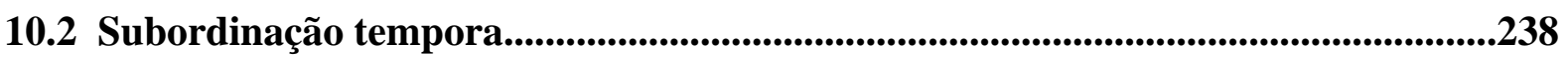

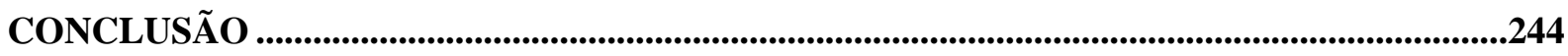

ANEXO 


\section{INTRODUÇÃO}

Esta tese descreve aspectos fundamentais da gramática do Laklãnõ, uma das duas línguas sobreviventes do subgrupo Jê Meridional, tronco Macro-Jê (cf. RODRIGUES, 1999), com foco especial nas classes de palavras, a partir de critérios morfológicos, semânticos e sintáticos que as distinguem, abordando na mesma medida também as estruturas das quais são núcleos, como os verbos, os nomes, as posposições e os adjetivos. Abordamos ainda os tipos de sintagmas, os tipos de oração, como estas se combinam, como são negadas, como se dá as perguntas sobre constituintes, e dedicamos um capítulo especial ao alinhamento e aspecto.

O autor da tese é falante nativo da língua Laklãnõ, mas além de sua intuição, os dados para este trabalho foram coletados junto ao seu povo. $\mathrm{O}$ autor não é, portanto, o único fornecedor de dados para a descrição que se fará adiante. Mas sim apenas uma das fontes, visto que este estudo se quer representativo da língua falada por um grupo indígena, das variações entre indivíduos por sexo, grupos de idade, especializações de cada um, enfim, da língua em sociedade, renovada a cada dia pela experiência dos seus falantes.

Vale ressaltar que na presente tese, embora tenhamos considerado o trabalho de mestrado realizado pelo autor, apresentamos uma análise diferenciada, em que a língua nativa e não o Português é a referência. Este estudo, portanto, é a primeira descrição linguística aprofundada do Laklãnõ, fundamentada em princípios de uma linguística antropológica, que toma a experiência cultural do povo Laklãnõ como referência para a interpretação das noções codificadas pela língua. Privilegiamos o estudo da gramática como conhecimento moldado no modo como os Laklãnõ veem o mundo e como nele interagem uns com os outros e com a natureza em que vivem e de onde tiram o seu sustento.

A presente tese associa uma descrição linguística à ideia de que a língua é um sistema, constituído de subsistemas dinamicamente interconectados, e funciona como uma ferramenta cultural fundamental para a comunicação humana (cf. SAPIR, 1949; JOURDAN \& EVERETT, 2008; 2012). Foram considerados os estudos linguísticos sobre o Laklãnõ por Wissemann (1968), Gakran (2005) e Urban (1985), assim como estudos sobre outras línguas Jê, como o de Cavalcante (1987a, 1987b, s.d.), Miranda (2014), Silva (2003) e Ferreira (2001), D’Angelis (1991, 2001). As principais referências teóricas foram Guéntcheva ( 1990, 2011, 2012) sobre aspecto, Dixon (1994) e Comrie (1987) sobre alinhamento, Schachter (1985) e Vogel e Comrie (2000) sobre classes de palavras, Grinevald (2002) sobre classificadores e Kaufman sobre questões de método. Os estudos de Rodrigues sobre o tronco 
Macro-Jê foram altamente importantes para a compreensão de características das línguas desse agrupamento genético (RODRIGUES, 1999, 2000a, 2000b, dentre outros).

Os estudos linguísticos da língua Xokleng foram iniciados na década de 1970, por Greg Urban, com o qual cooperei, ainda menino. Greg Urban aprendeu a língua Laklãnõ e pode falar com autoridade sobre a nossa organização social (1978), nossos discursos, nossos mitos (1986, 1989), e nossa própria língua (1985). Portanto, o objetivo principal dessa tese foi o de aprofundar os estudos gramaticais do Laklãnõ, já iniciados por Urban, apresentando uma descrição da fonologia segmental, das classes de palavras e de aspectos fundamentais da morfossintaxe, com foco especial na semântica que expressa com nitidez como os Laklãnõ veem, sentem e falam sobre si no mundo em que vivem, através de sua língua.

\subsection{JUSTIFICATIVA}

Os Laklãnõ foram contactados definitivamente em 22 de setembro de 1914. Cem anos depois do contato, a língua conta com raríssimos trabalhos linguísticos. Duas dissertações de mestrado, uma de autoria de Terezinha Bublitz, sobre a fonologia da língua, e outra de minha autoria sobre aspectos morfossintáticos da língua, além de dois artigos científicos, um de autoria de Gregor Urban (1985) sobre alinhamento e outro de Pinho (mimeografado) sobre alguns aspectos morfossintáticos em uma abordagem gerativa, com o qual colaborei com dados de minha língua, mas não com a elaboração do trabalho. Trata-se portanto de uma língua para qual estudos gramaticais e lexicográficos são fundamentais. E foi na minha prática de professor Laklãnõ, no dia a dia da sala de aula, que senti mais de perto a necessidade de organizar uma primeira gramática que servisse de base para os Laklãnõ desenvolverem estudos sobre sua língua nativa e que fosse também a base para a atualização da ortografia e para a elaboração de um dicionário e de outros materiais didáticos e paradidáticos. Mas também quería contribuir para os estudos linguísticos da língua Laklãnõ. Tudo isso me fez aprofundar os meus estudos, agora com a responsabilidade de produzir um estudo gramatical da língua com bases científicas, que resultasse em uma tese de doutorado. 


\subsection{METODOLOGIA}

A pesquisa desenvolveu-se primeiramente a partir da recolha de dados linguísticos junto aos mais velhos e, em seguida, junto a pessoas mais jovens e junto a adolescentes e crianças. Com esse procedimento, a ideia foi organizar um banco de dados que reunisse elementos representativos da fala da comunidade e que também fosse representativo da divisão que faz a língua Laklãnõ, ao refletir a distinção cultural de gênero biológico entre homem e mulher, macho e fêmea.

Foram realizadas entrevistas junto aos mais velhos sobre mitos, histórias vividas, e também junto a pessoas que já faleceram. Mas trabalhei também junto a pessoas mais jovens, gravando seus relatos sobre fatos da vida quotidiana e sobre conhecimentos específicos da cultura e sobre a natureza. Todas as entrevistas foram gravadas em sistema digital, transcritas e armazenadas no Banco de Dados de Línguas Indígenas do Laboratório de Línguas e Literaturas Indígenas da Universidade de Brasília.

A análise dos dados serviu-se de instrumentos de análise da linguística descritiva, como contraste semântico e de formas, distribuição complementar, e da noção de paradigmas, de excludência, entre outros. Procurou-se identificar os princípios que norteiam a gramática Laklãnõ e os padrões e regras que restringem a atualização da língua nos diferentes discursos proferidos no dia-a-dia das comunidades Laklãnõ. Os dados que serviram a esta tese encontram-se depositados no Banco de Dados Laklãnõ, que por sua vez está inserido no Banco de dados do Laboratório de Línguas e Literaturas Indígenas da Universidade de Brasília. 


\subsection{ORGANIZAÇÃO DA TESE}

A presente tese está assim organizada: uma introdução em que apresentamos a proposta de tese, uma justificativa, a metodologia empregada e a organização da tese; o capítulo I traz um pouco da história Laklãnõ, a luta por seu território, sua espiritualidade, sua relação com a natureza, os Laklànõ e os animais, a história do contato, a escola Laklãnõ e as perdas culturais; O capítulo 2 traz uma análise segmental dos fonemas do Laklãnõ, e algumas considerações sobre os padrões silábicos, fonotáticos e alguns processos fonológicos; o capítulo 3 trata das classes de palavras - substantivos, adjetivos, verbos, ineterjeições, ideofones, entre outras; o capítulo 4 descreve tipos de predicados em Laklãnõ; o capítulo 5 trata de alinhamento em Laklãnõ, partindo do estudo de Urban (1985) sobre as manifestações de ergatividade nessa língua, mas trata também de aspecto, estreitamente relacionado ao alinhamento da língua; no capítulo 6, mostro como se nega em Laklãnõ; no capítulo 7, trato de orações interrogativas; no capítulo 8, de construções comparativas e, no capítulo 9, de coordenação e subordinação. Esse capítulo é seguido de uma conclusão, a qual é, por sua vez, seguida das referências bibliográficas. Por último, apresento um texto em Laklãnõ, de autoria de Kanhaà Nanblá, meu avô. 


\section{CAPÍTULO I - UM POUCO DA HISTÓRIA DA SITUAÇÃO DOS POVOS INDÍGENAS NO BRASIL}

\subsection{PRELIMINARES}

O que se sabe sobre a situação contemporânea dos povos indígenas no Brasil é insuficiente. São informações dispersas e bastante heterogêneas quanto à sua origem, data e procedimentos de coleta de dados, sendo que muitas dessas informações são resultados de estimativas ou aproximações e não de contagem direta. Também não se têm muitas informações ou estimativas de desaldeados e povos isolados.

Ricardo (1995) fala que, apesar da dificuldade existente, estima-se que existam cerca de 270 mil indígenas no Brasil. Segundo o autor, a população tem aumentado gradativamente nos últimos 20 anos. Do ponto de vista demográfico, de acordo com o autor, a maior parte dos povos indígenas é formada por microsociedades que se apresentam à sociedade nacional com uma enorme sociodiversidade, sendo aproximadamente 206 etnias, falando mais de 170 idiomas. $\mathrm{O}$ autor acredita que é pouco perto do que existia, pois na época da invasão europeia, no século XVI, a população indígena era de 6 milhões de pessoas. Atualmente estes povos representam $0,2 \%$ da população existente no território nacional.

Rodrigues (2005) afirma que hoje são faladas no Brasil cerca de 180 línguas indígenas. Segundo o autor, este número refere-se somente às línguas das quais já há alguma documentação, ainda que mínima e, em princípio, um número bastante conservador, pois para o mesmo é possível que o número real esteja em torno de 200 línguas.

Apesar das dificuldades mencionadas anteriormente, no ano de 2010, o Instituto Brasileiro de Geografia e Estatística - IBGE - estimou que existem quase 900 mil indígenas, considerando que a população teve aumento gradativo nos últimos 10 anos. Assim, conforme o censo, estima-se que são aproximadamente 305 etnias, falando aproximadamente 274 idiomas. Assim a população indígena representa $0,4 \%$ da população existente no território nacional brasileiro. Conforme os dados acima, observa-se que nos últimos anos, apesar das pressões em todos os sentidos, a população indígena cresceu significativamente no território brasileiro. 


\subsection{O POVO XOKLENG}

De início, é importante esclarecer ao leitor sobre o uso dos termos Xokleng, e ao longo do trabalho falarei sobre a nova autodenominação Laklãnõ e seu valor enquanto denominação também da língua, da qual trata esta tese, falada pelo povo ao qual pertenço e que é a minha primeira língua.

\subsubsection{Território e Histórico dos Xokleng}

Os Xokleng, que também já foram conhecidos pelos não-índios por Botocudos, Botocudos do Sul ou Bugres ${ }^{1}$, já ocuparam vasta região do sul do Brasil, desde o centro do Paraná até o Nordeste do Rio Grande do Sul, incluindo quase todo o centro-leste do Estado de Santa Catarina (excetuando a orla marítima). (Ver o mapa).

\section{Figura 1 - Mapa da Região Sul}

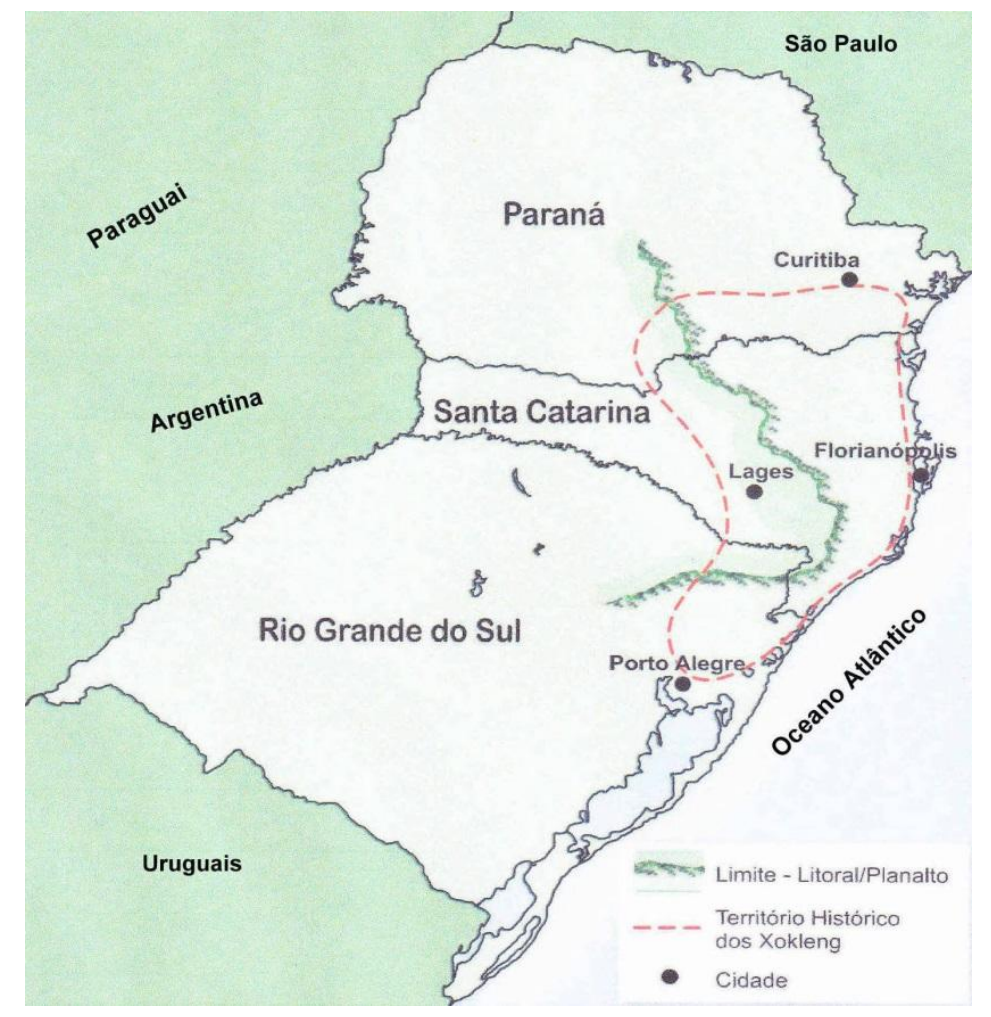

Fonte: Acervo pessoal de Nanblá Gakran

\footnotetext{
1 O termo "bugre" não é atribuído exclusivamente aos Xokléng. Trata-se de um termo depreciativo, significando "bárbaro", "pagão" e "não-civilizado", que é atribuído (ainda hoje) a populações indígenas no Sul do Brasil.
} 
Os primeiros registros, em documentação escrita, sobre a comunidade Xokleng, remetem às cartas de Jesuítas Espanhóis das Missões do Guairá, no início do século XVII². Entre outras coisas, faz-se referência nessas cartas à prática da cremação dos mortos. No final do século XVIII, a expedição portuguesa para "descoberta" dos campos de Guarapuava, no estado do Paraná, dirigida por Afonso Botelho de Sampaio e Souza, registrou em seu mapa daqueles campos, os aldeamentos indígenas que visitou, denominando seus moradores como “gentio Xaclan”. O avanço da colonização portuguesa, a princípio através da chamada "frente pastoril", foi aos poucos restringindo o território livre dessa sociedade indígena.

Na primeira década do século XIX, o príncipe regente português, Dom João VI, decretou, por meio da Carta Régia, "guerra justa" contra os Xokleng da região dos Campos de Lages, em Santa Catarina ${ }^{3}$. Duas décadas depois, por incentivo do governo imperial brasileiro, iniciam-se as investidas de colonização agrícola com recursos da introdução de imigrantes. As primeiras levas de colonos alemães começaram a entrar pelo ponto mais extremo sul do território Xokleng, no Rio Grande do Sul, por volta de 1830, ao mesmo tempo em que outros colonos alemães são igualmente localizados na região do Rio Negro, na divisa dos estados do Paraná e Santa Catarina, também em território Xokleng. Nesse tempo, dada a força da economia pastoril, os Xokleng já estavam impedidos de ocupar e, até mesmo, de penetrar boa parte dos seus territórios, em regiões de campos, indo aos poucos se refugiar nas serras da Mata Atlântica. Ali, foram alcançados pela penetração da frente agrícola colonizadora, tanto nas serras rio-grandenses como no território catarinense. Por volta de 1850 inicia-se o empreendimento colonizador norte-catarinense, como a introdução de famílias de agricultores europeus no Vale do Itajaí.

\footnotetext{
2 Pe. Montoya, em carta de 1630 (cf. D’Angelis \& Veiga 1996: 93-94).

3 A Carta Régia de 5 de Novembro de 1808, afirma: “... em todo o terreno que fica ao Oeste da estrada geral, desde a Villa da Faxina até a Villa das Lages, a maior parte das fazendas que estão na dita estrada, se vão despovoando, umas por terem os Índios Bugres morto os seus moradores, e outras com o temor que sejam igualmente vítimas e que até a mesma estrada chega a não ser vadeável (...) e constatando-me que os sobreditos campos e terrenos, regados por infinitos rios, são susceptíveis não só da cultura de trigos, cevadas milhos, e todas as plantas cereais e de pastos para gados, mas de linhos canhamos e de toda a qualidade de linho, assim como de muitas outras preciosas culturas, além de que se acham no mesmo território terras nitrogênio e muitas minas de metais preciosos e de outros não menos interessantes; sendo-me também igualmente presentes os louváveis frutos que têm resultado das providências dadas contra os botocudos, e fazendo-se cada dia mais evidente que não há meio algum de civilizar povos bárbaros, senão ligando-os a um escola severa, que por alguns anos os force a deixar e esquecer-se de sua natural rudeza (...) tendo se verificado na minha real presença a inutilidade de todos os meios humanos, pelos quais tenho mandado que se tente a sua civilização (...) sou servido por estes e outros justos motivos que ora fazem suspender os efeitos de humanidade que com eles tinham mandado praticar ordenar-vos: Em primeiro lugar, que logo desde o momento em que receberdes esta minha Carta Régia, deveis considerar como principiada a guerra contra estes bárbaros índios (...) e com a menor despesa possível da minha Real fazenda, perseguir os mesmos índios infestadores do meu território; procedendo a declarar que todo Miliciano ou qualquer morador que segurar algum destes Índios poderá considera-los por quinze anos como prisioneiros de guerra, destinando-os ao serviço que mais lhe convier..." (apud Moreira Neto 1972: 408- 409).
} 
O conflito entre os Xokleng e a invasão de seus territórios ganham, desde então, maior repercussão, seja pelo fato de envolver famílias de imigrantes e respectivos governos estrangeiros, seja pelo fato de haver, no país, um maior número de veículos de imprensa. Um terceiro fator, certamente, seria o fato de os Xokleng perceberem que se encontravam em seus últimos refúgios, sem alternativas a não ser o enfrentamento direto com os invasores, como forma de garantir seu espaço e território livre para sua sobrevivência. As comunidades Xokleng, nessa situação, foram cada vez mais encurraladas e perseguidas. Foram elas que sofreram, sobretudo em Santa Catarina, a prática (frequentemente acobertada ou até estimulada pelas autoridades locais) das expedições de "bugreiros", grupos armados especializados no extermínio de comunidades indígenas. Não é possível conhecer o número de indivíduos massacrados nesse longo período de invasão agressiva que se estendeu até a segunda década do século XX. Os Xokleng, que outrora exibiam grandes roças, às quais associavam as práticas de caça, pesca e coleta, foram reduzidos a comunidades de migrantes caçadores-coletores refugiados nas florestas e atormentados pelo temor das práticas dos "bugreiros". Assim, o antropólogo norte-americano Jules Henry descreveu-os, em um clássico estudo ${ }^{4}$, nos anos 30 do século XX, poucos anos após o estabelecimento de relações “amistosas" entre os Xokleng e os não-índios no Vale do Itajaí.

Em 1912, um primeiro grupo Xokleng aceitou relações amistosas com funcionários do Serviço de Proteção aos Índios (SPI) ${ }^{5}$, dirigidos por Fioravante Esperança, na região de Iratim, próxima a Palma (PR). Posteriormente, esse grupo desentendeu-se com o SPI e refugiou-se mais além, nas matas do rio dos Pardos, em Santa Catarina, sendo reencontrado anos depois por uma equipe do SPI dirigida por João Pereira Gomes (João “Serrano”).

Segundo Veiga (2004), os Xokleng, antes do contato oficial com a sociedade não indígena, além da caça e da coleta, praticavam a agricultura e também viviam da caça e da coleta do pinhão (fruto da araucária ou pinhão). De acordo com a autora, os Xokleng viviam em aldeias permanentes e ao longo do tempo, em função dos conflitos e das perseguições dos brancos tornaram-se migrantes, não mantendo mais acampamentos fixos e, desta forma, não mais cultivavam a terra. Isso é diferente do que Santos (1973) afirma, que os Xokleng são povos seminômades, sem justificar a razão. Este povo caçador e coletor refugiava-se nas

\footnotetext{
${ }^{4}$ HENRY, Jules. Jungle people. A Kaingáng tribe of the highland of brasil. New York: J. J. Augustin Publisher 1941 ( $2^{\mathrm{a}}$ ed.: New York: Vintage Books, 1964).

5 O SPI foi criado, em 1910, como agência federal oficial para as relações com as comunidades indígenas, como resultado de uma campanha nacional, liderada, sobretudo por grupos positivistas e tendo como um dos motivos a repercussão das constantes notícias divulgadas na imprensa do Rio de Janeiro e São Paulo sobre confrontos entre índios e brancos no Sul do país (em território Xokléng) e no estado de São Paulo (em território Kaingáng).
} 
florestas pelo medo das práticas dos bugreiros, que estavam exterminando-o. Da mesma forma, por desconhecimento, Cunha (2012) considerou que os Xokleng eram um povo 'nômade', dando a entender que, ao longo de toda a história, esse povo sempre foi um grupo de pessoas que nunca manteve residência fixa. Contudo, nos relatos que gravamos, entre os anos 1984 a 1985, os anciãos nos narraram que, no passado distante, além da caça e das coletas, praticavam a agricultura, plantavam milho e abóbora, mas também viviam da caça e da coleta do pinhão zág zy. Essa informações conferem com o que Veiga (2004) afirma em sua pesquisa.

Entre os Xokleng, a residência após o casamento era com os parentes da esposa. Isso não significava que o marido diminuía seus laços com a família extensa de origem, pois davam grande valor às lealdades paternas. Por outro lado, são muito reveladores os relatos que gravei na década de 1980. Existia entre os Xokleng poligamia, mas também casamento monogâmico, mas não existia poliandria, ou seja, união conjugal com mais de um homem. Greg Urban (1978) também afirmou que, além de casamento monogâmico, há a poligamia entre os Xokleng, diferentemente da afirmação de Jules Henry (1935) de que havia além de casamentos monogâmicos e poligamia, a poliandria e, ainda, casamentos entre pessoas do mesmo sexo. Com base nos relatos que gravei, nos anos 80, e como membro do povo Xokleng, discordo totalmente dessa informação de Henry (1935). Consideramos que essa informação não é verdadeira e é também distorcida e muito preconceituosa, pois viola a imagem histórica desta sociedade.

Os relatos, que gravei nos anos de 1980, apontam que os Xokleng eram um povo migrante, tinha seus hábitos alimentares já estabelecidos pelo local onde se encontrava durante o decorrer do ano. Assim, dividiam e organizavam seu tempo em dois períodos, lo 'verão' e kutxó 'inverno'. Passava-se o inverno kutxó no planalto catarinense e no período do verão lo desciam para o vale, em que se reuniam e construíam ranchos, em semicírculo, voltados para uma praça onde faziam os rituais, a preparação de iniciação, casamentos, ritos funerários e confraternizavam entre si em geral. Além disso, caçavam, planejavam ataques aos inimigos e também o novo encontro para o ano seguinte.

Quando o povo Xokleng migrava, tinha seus hábitos alimentares estabelecidos pelo local onde se encontrava, do planalto ao litoral e do litoral ao planalto, a cada ano. Isso era feito pela disponibilidade de alimentos, tendo o milho como principal alimento presente em todo tempo e o peixe no litoral, o pinhão com carne de caça nas serras. O milho e o pinhão eram armazenados num cesto e enterrados num banhado para mantê-los conservados por muito tempo devido à baixa temperatura. Para todos os tipos de festas, os alimentos eram 
preparados conforme a culinária tradicional e o 'mõg' era preparado com mel e xaxim para ser bebido em ocasiões especiais. Terminada a estação cerimonial no período do verão ló, a aldeia se desfazia e os grupos saíam para mais uma jornada no planalto no período do inverno kutxó, e assim se reencontravam novamente no verão seguinte para outra cerimônia já planejada no verão anterior.

\subsubsection{História do nome Xokleng e seus sentidos}

Segundo Santos (1973), o nome 'Xokleng', por meio do qual o povo é conhecido, tem provocado muitos debates, desde o primeiro momento de contato com a sociedade não indígena, ocorrido em 1914. Várias denominações foram dadas para este povo, ou seja, foram as mais variadas: bugres, Botocudos do sul, Aweikoma, Xokleng, Xokrén, Kaingáng de Santa Catarina e Aweikoma-Kaingáng. Estas últimas denominações foram dadas devido à proximidade linguístico-cultural existente entre os Xokleng e os Kaingáng ${ }^{6}$.

O antropólogo Jules Henry (1935), nas suas primeiras publicações sobre esse povo, apesar de denominá-los Kaingáng, admitiu que havia diferenças linguístico-culturais entre eles e os Kaingáng propriamente ditos. Segundo Urban (1985), os Xokleng no passado originaram-se dos Kaingáng e a separação destes se deu devido a fissões de suas patrimetades. Urban (1985) informa-nos que o termo Xokleng é muito genérico e não dá identidade ao povo.

De poucos pesquisadores que estudaram sobre o povo Xokleng, Silvio Coelho dos Santos, antropólogo brasileiro, foi o que mais trabalhos publicou a respeito da sociedade Xokleng. Segundo Santos (1973, p. 31), de muitas denominações que foram atribuídas a esse povo, prevaleceu o termo Xokleng, que acabou sendo incorporado ao povo como denominador de uma identidade externa e usado em suas lutas políticas junto à Fundação Nacional do Índio - FUNAI e aos meios de comunicação. A última comunidade remanescente desta sociedade, atualmente é habitante do vale do Itajaí em Santa Catarina.

\footnotetext{
${ }^{6}$ Segundo a determinação da Associação Brasileira de Antropologia, utiliza-se o nome das comunidades Indígenas sempre no singular.
} 


\subsubsection{Autodenominação atual}

Segundo Gakran (2005), o povo não reconhecia o termo Xokleng como sua autodenominação. Para a comunidade, o termo Xokleng é demarcador do olhar do colonizador sobre a comunidade e não desta como povo. Por essa razão o povo nunca se sentiu confortável com essa denominação. Segundo as pessoas da comunidade, que foram consultadas, o nome Xokleng foi dado por pesquisadores e não os identifica como povo devido ao seu significado não ser muito agradável e, por isso, o povo se sentia humilhado com essa denominação.

Num processo recente de recuperação das histórias e de suas origens, a comunidade iniciou uma discussão sobre redenominação, procurando resgatar aquele que considera o verdadeiro nome que os distingue e identifica enquanto povo. Assim, partindo daquele questionamento, em conjunto, os membros da comunidade buscaram reconstruir e redefinir a sua identidade, sobretudo, em conversa com os mais idosos, na tentativa de recuperar informações sobre as histórias e, portanto, redefinir a sua autodenominação. Na pesquisa mencionada, chegou-se a algumas conclusões sobre a etimologia do nome mais comum atribuído a eles, como xó ou txó 'paredão de pedra', 'rocha', 'gruta de pedra'; e kleng ou klẽ 'montanha'. Essa interpretação do nome vem de um fato que foi lembrado durante a pesquisa citada. De acordo com Gakran (2005), o pesquisador ${ }^{7}$ perguntou para seu parente como eles se protegiam da chuva e este respondeu dizendo que, em grande época de chuva, protegiam-se debaixo dos paredões de pedra.

$\mathrm{Na}$ pesquisa mencionada, chegou-se a outra interpretação sobre o mesmo nome: Xokleng ou txuklẽg 'aranha'. Outro pesquisador perguntou como eles faziam quando matavam um boi nas fazendas dos não-índios e o parente consultado, sobre o nome txuklẽg, respondeu que, quando matava um boi, eles o esquartejavam e um homem carregava tudo nas costas, numa mochila feita por eles, de taquara. Interpretando esta informação, os nomes foram comparados com o nome para aranha. Dessa forma, conclui-se que o nome Xokleng, de maneira equivocada ou preconceituosa, identificava o povo como homens da montanha ou homens que vivem debaixo de paredões de pedras ou povo da caverna, ou, finalmente, homens-aranhas.

É importante citar que, em uma das histórias que gravei com os sábios anciãos, entre 1983 a 1985, foi mencionado o nome laklãnõ. Segundo os sábios, os Xokleng eram

\footnotetext{
${ }^{7}$ De acordo com Gakran (2005), os informantes na época não sabiam o nome do pesquisador.
} 
conhecidos e chamados por outros grupos indígenas ou facções de Laklãnõ. Considerei importante falarmos sobre o porquê de outro grupo denominá-los com o termo de Laklãnõ. Segundo os relatos dos anciãos, que consultamos na década de 1980, quando o povo Xokleng formava uma família numerosa, ou seja, formando entre dez (10) ou mais famílias, estas não se entendiam mais com o restante do grupo, por entender que são uma ameaça para o restante do grupo e com isso, essas famílias se separaram e formaram outro grupo ou uma nova facção.

Com o passar do tempo, as famílias que se separam, retornaram para o grupo deixado para guerrear, tirando as mulheres para se casarem. Em uma dessas guerras, a outra facção armou uma cilada e matou um dos homens Xokleng. Para se vingar, o grupo de homens Xokleng foi atrás dessa outra facção para acabar com eles. Segundo o relato, quando este grupo alcançou a outra facção, era kutyg txi, próximo de meia noite, no local onde estavam acampados. Ao chegarem perto, viram que eram os que mataram um dos homens Xokleng. Cercaram todo o acampamento desse outro grupo, conforme as combinações, deram um sinal para dar início ao ataque. Ao ouvir o sinal, um dos líderes da outra facção falou para os demais grupos: 'Ouviram este barulho, estamos todos cercados; agora por causa de vocês, vou ser matado, porque mataram aquele homem. Estes Laklãnõ andam à noite, porque eles conhecem todos estes cantos e conhecem todos estes caminhos. Vocês acham que vão matar um deles e deixar por esquecidos? Segundo os anciãos, naquele instante o outro grupo Xokleng que estava ali próximo, ouviu a outra facção falar sobre eles. Depois de ouvir isso, atacaram e mataram vários homens do grupo e alguns fugiram.

Ao longo da história do povo, esse fato foi transmitido de geração a geração através da oralidade e, por essa razão, o termo Laklãnõ já era do conhecimento da comunidade, pois já se ouvia dos seus ancestrais. Passados mais de oitenta (80) anos de contato com a sociedade não indígena, a comunidade decidiu pesquisar sobre esse termo, pois queria uma nova autodenominação para si própria que os identificasse como povo. Nesse sentido, a própria comunidade tentou pesquisar juntos aos anciãos sobre o termo Laklãnõ. Nessa pesquisa, a própria comunidade chegou a um consenso de autodenominar-se "Laklãnõ", ou seja, 'povo que vive onde nasce o sol' ou 'gente do sol' ou ainda 'povo ligeiro'. Entretanto, do ponto de vista linguístico, sugere-se que a tradução literal mais apropriada seja próxima de "os que são descendentes do Sol” (ou, mais tecnicamente, do ponto de vista antropológico, "os do clã do Sol") Desse modo, o termo "Laklãnõ" vem ganhando espaço político, interno e externo, através do movimento de recuperação da língua materna, incluindo os registros das histórias antigas e o ensino bilíngue. Urban (1978) em suas pesquisas, no início dos anos 70, também 
reconheceu como "Rakranõ", considerando que esta "facção" foi contatada em 1914 na foz do Rio Platê, e observou que esse era o termo com o qual se autodesignavam ${ }^{9}$.

\subsubsection{O meio ambiente e a espiritualidade na fala do laklãnõ/Xokleng}

\subsubsection{O ritual de iniciação das crianças}

A maior festa dos Laklãnõ/Xokleng acontecia por ocasião da furação dos lábios dos meninos "glókózyn". Neste ritual, vários grupos se reuniam para comemorar com danças ãgglan e muita bebida feita à base de mel, água e xaxim e, depois de pronta, era chamada de $m \tilde{g}$. O povo considerava importante que, após os três a cinco anos de idade, os meninos tinham que ter botoques inseridos no lábio inferior e que isso fazia parte da tradição. Já as meninas, com a mesma idade, recebiam 'tatuagens' ou marcas na perna esquerda, abaixo da rótula.

Os padrinhos responsáveis pela perfuração labial e também pelas tatuagens eram os mesmos que enterravam o cordão umbilical da criança ao nascer. Esse ritual de enterrar cordão umbilical não era simplesmente de enterrar, mas sim tem todo um conjunto de procedimentos: moía algumas ervas medicinais e depois era passado pelo cordão umbilical e era enterrado próximo de uma planta que fosse forte e não quebrasse ou morresse fácil. Segundo a crença, a criança poderia crescer com saúde e ter uma vida longa. A pesso a enterrar o umbigo da criança, mais tarde, acompanharia o desenvolvimento e socialização dela até a fase adulta. Normalmente, os afilhados eram os incumbidos da cremação de seus padrinhos quando morriam.

Atualmente não há mais cerimônias de iniciação tradicional entre o povo Laklãnõ/Xokleng, nem para meninos e nem para meninas, apenas estão vivas em suas memórias.

\footnotetext{
8 Urban escreveu Raklanõ na escrita Kaingáng, mas a escrita correta na ortografia atual Xokléng pode ser Laklãnõ'.

9 Segundo Urban (1978: 346), este poderia ser contração de expressão ra ydn kra nõ ou la jul klãñ̃, povo do lugar que o sol levanta.
} 


\subsubsection{Espaço e espiritualidade dos Laklãnõ/Xokleng}

De acordo com os relatos dos anciãos que colaboraram com as informações para esta pesquisa, a mata nativa dos planaltos era de araucária e isso era fonte de alimento para os Laklãnõ/Xokleng durante todos os meses de inverno. Segundo os mesmos, havia grandes disputas com os Kaingáng e Guaraní. Esses povos eram denominados pelos Laklãnõ/Xokleng pelo nome de gógklózy tõ pléj ${ }^{10}$. A guerra com o último grupo era pelo seu espaço territorial, pelos pinhões e por toda a fauna do planalto e da orla marítima, ou seja, desde o estado de Rio Grande do Sul até estado do Paraná. Na guerra com os inimigos gógklózy tõ pléj, Laklãnõ/Xokleng usavam arcos, flechas, lanças e bordunas.

Os Laklãnõ/Xokleng, historicamente, eram religiosos ${ }^{11}$, ou seja, desde o passado remoto já acreditavam que na parte de cima (superior) fica o céu e no lado de baixo (inferior) fica a terra. Os mesmos acreditavam que no lado de cima, que é o céu, existem seres ãggaplẽg (espíritos) morando igual como ocorre na terra. Os Laklãnõ/Xokleng também acreditavam que há uma vida após a morte. Segundo suas crenças, a vida continua no lado de lá ${ }^{12}$ após a morte e eles continuam a praticar suas atividades que praticavam antes de seu falecimento.

Como quaisquer outros povos nativos, os Laklãnõ/Xokleng acreditavam em espíritos 'gyjun ${ }^{13}$, e 'kuplẽg ${ }^{14}$, que habitam entre as árvores, nas montanhas, nas cavernas ou no paredão de pedras, nas correntezas d'água, e nos ventos. Para este povo, todos os animais pequenos ou grandes têm espíritos e o encontro com gyjyn (espírito) poderia ser perigoso, mas também poderia ser bom se oferecesse uma ajuda em seu cotidiano. Acreditavam também que os animais tinham espírito que os controlavam e protegiam, permitindo ou não aos homens matá-los. Como foi citado anteriormente, os Laklãnõ, por ser um povo muito religioso, acreditava que existia um ser superior que está acima de nós, que é Ãgglẽnẽ

Iniciei minha pesquisa ainda jovem, em março de 1984 e a continuei até junho de 1985, registrando as histórias do povo Laklãnõ/Xokleng. Na época, a intenção inicial não era

\footnotetext{
${ }^{10}$ Em Laklãnõ a palavra gógklózy tõ pléj significa o seguinte: gógklózy $\rightarrow$ botoque, pléj $\rightarrow$ agulha $=$ botoque igual agulha; os que têm botoque fino, igual agulha.

${ }_{11}$ Para os Laklãnõ tudo era sagrado, acreditava-se na natureza, na existência de um ser supremo.

12 Informação das histórias e narrativas do povo Laklãnõ (Xokléng) que gravamos nos anos 80. Os anciãos que nos informaram eram considerados os mais sábios da comunidade na época, hoje já falecidos.

13 'gyjun' espírito familiar, espírito que dá poderes.

14 'kuplẽg' espírito dos mortos, almas.
} 
registrar em livro ou fazer uma análise linguística, mas documentá-las em fitas-cassete para preservação das histórias e cultura do povo ao qual pertenço. Esse trabalho permaneceu como meu acervo pessoal e apenas com a orientação dada por Urban sobre transcrição de dados. Assim transcrevi algumas histórias das fitas gravadas para a escrita Laklãnõ/Xokleng da forma como entendia. $\mathrm{Na}$ época da coleta das histórias, utilizei gravador simples, fita K7, e depois transcrevi a próprio punho tudo em caderno, sem imaginar que num futuro próximo este corpus serviria como o maior tesouro da história do povo Laklãnõ/Xokleng. Hoje é um grande tesouro, reconhecido pelo povo, pois todos os grandes narradores Laklãnõ, autores das histórias deste corpus, já faleceram. Da mesma forma, sem imaginar que num futuro próximo todo esse material serviria como material de leitura e também como base para a elaboração de uma gramática de referência da língua, como a presente tese de doutorado.

Em uma das histórias que gravei, narrada por anciões, a história fala que depois do contato em 1914, por volta de 1927, um pouco mais de dez anos de contato, um dos últimos e maiores kujá 'pajé', e nome Kámlẽn, antes de sua morte, falou para as pessoas que estavam junto dele, apontou com a mão para o céu, dizendo que o buraco ou porta do céu ficava ali naquela direção, "no sentido oeste". O mesmo afirmou que, por aquela porta estava subindo com um "Ser" com o nome "jun, juju ${ }^{15 "}$ para morar junto com ele no além (céu), e lá estaria intercedendo por eles e tudo o que eles precisavam era só pedir, que ele próprio os estaria ajudando. Diante da fala do kujá, Kámlẽn, observamos também que nas outras histórias gravadas também se afirma a versão de existir um céu e uma terra já desde os tempos dos nossos ancestrais, antes do contato com a sociedade não indígena.

Considera-se relevante destacar que, por volta de 1927, quando o grande kujá Kámlẽn falou isso antes de sua morte, o cristianismo não havia sido penetrado na Terra Indígena. Ou seja, o cristianismo foi implantado na comunidade Laklãnõ/Xokleng somente em 1948, ou seja, aproximadamente vinte anos depois. Nesse contexto, observa-se que o povo Laklãnõ/Xokleng acreditava e diferenciava a existência de um céu e uma terra. Também diante dessa fala do xamã Kámlẽn, observamos claramente que o povo acreditava que havia seres no céu como na terra, além da existência do espírito dos animais, bem como de um "Ser" superior que está acima de nós.

Reforçando esta mesma fala, em outra história que gravamos na mesma época, também afirma-se sobre a existência de um céu e uma terra, mas de outra forma. Observemos na íntegra a tradução de uma parte da história que gravei: '...no passado distante, havia um gavião igual a onça que comia as pessoas. Para comer o ser humano, a gavião-onça levava

15 Esta história, gravada pelos anciãos nos anos 80, e permanece ainda na íntegra. 
para o céu a pessoa. Raptava as pessoas e levava para o céu e lá comia com os demais outros gaviões... Um dia Kujánhkág e seu irmão Nãnbág foram caçar e a gavião-onça raptou Kujánhkág naquele dia. Seu irmão Nãnbág, passado um tempo, subiu atrás dele lá no céu para buscar seus ossos [...]. Mas antes deste acontecimento os dois iam caçar juntos, eles sempre falavam um para outro dizendo: 'se um dia um de nós for raptado pelo gavião-onça, aquele que ficar vai atrás buscar os ossos lá no céu e quando trouxer, colocar num lugar distante num cesto que depois de algum tempo, vai se transformar num homem e assim vai retornar novamente [...]. ${ }^{16}$

Segundo a história, alguns dias depois aconteceu o que os dois previam, o Kujánhkág de fato foi raptado pelo gavião-onça. Como seu irmão Nãnbág tinha contato com os espíritos de gavião, lembrou o que havia combinado com seu irmão e então pegou as penas e fez suas asas e o rabo. Depois de prontos, subiu até o céu para buscar os ossos do seu irmão, conforme haviam combinado. Mas, antes de subir, falou para seus parentes dizendo: '...Eu vou subir no céu buscar os ossos daquele homem que foi raptado pela gavião-onça! Quando eu subir para buscar, vocês me esperam aqui! Por ali fica o buraco (porta) do céu! Então vocês ficam de olho naquele buraco, vou entrar ali, para vocês me verem, fica de olho lá!

Ao falar isso para os parentes, ele apontava para o céu no sentido oeste como Kámlẽn, o maior pajé Laklãnõ/Xokleng que falou antes de sua morte, em 1927. Conforme a história, quando Nãnbág chegou ao céu, ele viu e teve contato com seres viventes do sexo masculino e feminino. De acordo com a história, há uma vida lá no além semelhante à vida aqui na terra, ou seja, há um céu e uma terra. Isso reforça nitidamente que a introdução do cristianismo na aldeia, veio para complementar a sua crença, que já existia ao longo de toda sua história desde o passado remoto até os tempos atuais. Pode-se ainda observar claramente na história relatada acima que a sociedade Laklãnõ/Xokleng, no passado distante, acreditava numa reencarnação após a morte.

Outra história, também gravada por mim na mesma época nos anos 80, complementa o que foi dito nas outras duas histórias citadas anteriormente, mas de forma diferente. Isso confirma que a crença e a espiritualidade do povo Laklãnõ/Xokleng era conforme seus costumes e suas tradições. Essas histórias deixam claro sobre a existência da continuação da vida após a morte.

Os Laklãnõ/Xokleng, acreditavam que poderiam adotar espíritos de crianças e colocá-los no ventre de sua mulher ou da filha, para que a criança pudesse renascer, se já fosse falecida. Na quarta história, que gravamos no ano de 1985, um dos maiores kujá 'pajé',

16 Observamo que o povo Laklãnõ/Xokléng acreditava, antigamente, numa reencarnação. 
Ulol, quando morria um filho ou um neto, buscava o espírito dessa pessoa, seja adulta ou criança, na outra dimensão onde estão as almas dos que se foram desta vida, trazia-as e colocava-as no ventre da mãe ou da filha e, assim, renascia o filho ou o neto novamente com as mesmas características físicas. Esses costumes e crenças estenderam-se até os anos 60 e com a imposição do cristianismo foram deixados de lado, mesmo que no fundo até os dias atuais ainda se acredita. Segundo essa história, no lugar onde ele buscava o espírito da pessoa falecida, havia lugar separado para as crianças e também para os adultos, e a vida no lado de lá após a morte continua. Essa versão reforça o que foi citado anteriormente de que o povo Laklãnõ/Xokleng acreditava numa reencarnação após a morte. O kujá 'pajé’ Ulol, segundo a história, por ter contatos com vários espíritos, ao ver a necessidade dos seus parentes, chamava os bichos de caça, como anta, porco-do-mato (queixada), caitetu, entre outros animais de caça, para os parentes matarem e comerem a carne.

No passado, entre os Laklãnõ/Xokleng, os mortos adultos eram cremados, conforme seus costumes, e seus restos mortais eram colocados em um cesto e enterrados. Já as crianças eram enterradas, pois acreditava-se que seu espírito retornaria ao ventre da mãe e renasceriam novamente. Para isso acontecer, os pais tinham que ir todos os dias no final da tarde ao lugar onde a criança foi enterrada para chamar seu espírito e, segundo essa crença, o espírito retornaria junto com os pais para casa e a mãe ficava grávida novamente; e a nova criança que nascia, recebia o nome do(a) já falecido(a). Atualmente, entre os Laklãnõ mais velhos, mantém-se ainda viva essa crença de que o espírito da criança, depois de morta, retorna para os pais mesmo que a igreja condene esta crença tradicional.

Sob esta imposição da igreja, grande parte das plantas medicinais utilizada no passado pelos kujá, para a cura de doenças corporais e as práticas de exorcismo tradicionais, foram deixadas de lado, e todos esses papéis foram ocupados por pastores evangélicos. Assim, mesmo fazendo orações, os Laklãnõ lembram das técnicas de cura utilizadas pelos antigos kujá no passado.

A respeito das histórias tradicionais contadas de geração a geração entre os Laklãnõ/Xokleng, que foram citadas, quero fazer um breve comentário sobre o meu ponto de vista como membro nativo desta sociedade. Desde o início da humanidade, acredita-se que existe outra vida após a morte. A morte é uma passagem da vida terrena para o outro lado da vida, para o convívio com os deuses. Sobre esta ideia de 'alma sobrevivente' após a morte, interpreto que tudo o que vemos no mundo são imitações das ideias perfeitas do mundo, que consiste em várias ideias sobre a mesma teologia, conforme suas representações nas variadas culturas e cada uma com suas crenças tradicionais, diferentes umas das outras. Sob este olhar, 
o que está no mundo é cópia daquele modelo que é interpretado de diferentes formas. Desse modo, interpreto o que considero adequado para cada cultura sobre a ideia da alma sobrevivente.

Para os cristãos, a alma do homem, após sua morte, vai para um lugar preparado chamada 'paraíso', para esperar o dia do juízo final, onde será julgada conforme suas obras aqui terrenas. Assim, uns ganharão a absolvição e outros a condenação eterna. Quase com a mesma interpretação, os católicos pregam que a alma do homem após sua morte fica num lugar chamado de 'purgatório', para se purificar e depois serem perdoados no dia do juízo final.

O filósofo Platão (428 a.C. - 347 a.C) acreditava que as almas migram de um corpo para outro após a morte; uma alma transmigra para vários corpos antes que o seu ciclo de perfeição chegue ao fim. Mas, conforme as suas obras, elas poderão ter uma punição de formas diferentes. Para Platão, as almas que tiverem praticado a virtude comum, não filosófica, poderão reencarnar em animais mansos e sociáveis ou em homens honestos e virtuosos. Para ele, as almas que cometeram crimes gravíssimos e irreparáveis, a punição é longa. De acordo com ele, por ter praticado a injustiça, passará pela dor e pelo sofrimento, tanto na terra como no mundo subterrâneo de Hades, que é o lugar para onde irão as almas após a morte.

Com o mesmo ponto de vista dos cristãos e do filósofo Platão, o povo Laklãnõ/Xokleng interpreta, desde o passado remoto até os dias atuais, sobre a vida terrena e sua alma após a morte, como podemos observar nas narrativas sobre esse tema. Para os Laklãnõ, nessa percepção, o homem é um ser de duas dimensões, composto de corpo e alma. Isto confirma o que Platão afirmava sobre a ideia de duas dimensões humanas. De acordo com os meus colaboradores anciãos, a história do kujá Ulol, citada anteriormente, afirma que há um lugar preparado para as almas daqueles que se foram dessa vida terrena e que nesse lugar todas as almas, tanto de adultos quanto de crianças, ficam esperando seus entes queridos que um dia encontrarão. Enquanto esperam seus entes queridos, eles continuam fazendo seus afazeres do dia a dia que faziam na vida terrena. Para os Laklãnõ/Xokleng, a vida continua no mesmo ritmo depois da morte. Isso significa que para eles a morte é uma passagem da vida terrena para uma vida nova.

Sobre esta ideia de alma sobrevivente, entendo que a ideia sobre a 'alma' ou vida após a morte, independente das etnias e crenças religiosas ou filosóficas, segue o mesmo raciocínio e com a mesma ideologia do que tem sido observado em outras sociedades com cosmologias distintas. 
Os Laklãnõ/Xokleng historicamente são um povo religioso ${ }^{17}$ que acredita e faz uma conexão entre um universo mortal e imortal, ou seja, o povo distingue dois universos, o superior e o inferior. Segundo essa crença, na parte superior há seres sobrenaturais semelhantes a seres humanos que moram lá, mas com vida imortal. Já na parte inferior, que é a terra, há os seres humanos mortais, de acordo com a diferenciação que os Laklãnõ/Xokleng faziam entre esses dois universos ${ }^{18}$.

\subsubsection{A relação com a natureza e a espiritualidade}

Nosso objetivo é trazer à luz e mostrar ao leitor o que estava por trás da cortina do tempo, a reciprocidade e o respeito que o povo Laklãnõ/Xokleng tem pela natureza e sua espiritualidade. Nesse sentido, a natureza é considerada como referência fundamental dessa sociedade.

Para os Laklãnõ/Xokleng, tudo na natureza demonstra ter fundamento religioso e espiritual. A relação deste povo com a natureza é permeada por sentimentos de que tudo é sagrado. Dessa forma, os bichos têm espíritos e, por isso, quando vão matar qualquer animal de caça para se alimentar, eles pedem permissão e perdão, explicando porque o animal está sendo morto, por necessidade de comer carne. De modo igual, para retirar mel de uma colmeia é pedido a permissão e perdão às abelhas, explicando para que o mel está sendo tirado. Por considerarem que as árvores também têm espíritos, elas não eram derrubadas, pois havia uma forma de manter elas em pé, subindo nela e furando diretamente no local onde está a abelheira sem precisar derrubá-la.

Conversar com a natureza, entre os Laklãnõ/Xokleng, não foi descrito apenas como algo restrito aos kujá 'pajé', que vivenciavam isto no passado e ainda vivem de acordo com esses valores. Antigamente, quando os Laklãnõ/Xokleng viviam no mato, tinham uma relação de afeto com a natureza, conversavam com ela para conseguirem o que precisavam. Em razão disso, não tinham medo das cobras e não precisavam matá-las, pois conversavam com elas para que não lhes picassem. Neste sentido, entre os Laklãnõ/Xokleng, a habilidade de comunicação com os seres da natureza é comum a qualquer indivíduo em suas atividades do cotidiano, como a caça e a agricultura. A comunicação com a natureza é possível, porque

\footnotetext{
${ }_{17}^{17}$ Para os Laklãnõ tudo era sagrado, acreditava-se na natureza, na existência de um ser supremo.

18 Informação do acervo pessoal gravado nos anos 80. Os colaboradores anciãos eram os mais velhos da comunidade e que hoje já são falecidos.
} 
segundo suas crenças e costumes, todos os elementos da natureza têm espírito, pois para os membros da sociedade este hábito faz parte do conhecimento popular.

Segundo os Laklãnõ/Xokleng, o ser da natureza, quer seja da flora ou da fauna, estabelece uma teia espiritual com as pessoas. Deve-se sempre respeitar aquele que está interligado espiritualmente com sua linhagem. Assim, os seres espirituais da natureza levam o nome de gyjun (espírito) e acima desses há um maior que comanda, designado de gyjun tõ gynhmõ nẽ (espírito que está acima) ou ãggklẽnẽ (alguém acima de nós). Este ser maior foi relacionado com o nome de Jesus, adaptando as crenças cristãs às crenças tradicionais Laklãnõ/Xokleng.

Além da conversação direta com os seres da natureza, há também tipos de animais que atribuíram e são determinados para diferentes tipos de manifestações, como ronco do bugio ou de pássaros que podem representar mudança de tempo ou a morte de alguém. De acordo com essa crença, há dois tipos de passarinhos que podem comunicar sorte ou azar. Estes pássaros são considerados sagrados até os dias hoje e ele não podem ser mortos. Essa espiritualidade atualmente é valorizada e estimulada para que isso não venha a se perder ao longo do tempo pela sociedade, restabelecendo um novo equilíbrio por meio do retorno aos costumes tradicionais de conexão com a natureza, permitindo que eles recriem sua identidade e cultura com base nos costumes ancestrais, apesar das transgressões e rupturas decorrentes do contato com a sociedade envolvente.

Pode-se perceber que a espiritualidade Laklãnõ/Xokleng e o seu conhecimento da natureza, descritos ao longo desse texto, é diferente da sociedade 'civilizada', o que se pode perceber e o que demonstra o convívio equilibrado desse povo com a natureza, por possuírem os valores culturais dos seus ancestrais com o respeito, o que é evidenciado principalmente na forma de extração de recursos naturais de que necessitam, por meio de pedidos de permissão à natureza.

Esses cuidados em relação à natureza, demonstrados por meio de um sentimento de afeto e de permissão para o seu uso, podem ser compreendidos no contexto da realidade tradicional, demonstrando um extremo sentimento de respeito e de integração com a natureza que, no caso em questão, sustenta um sentimento de pertencimento do povo Laklãnõ/Xokleng à natureza como um todo. No entanto, percebe-se, na descrição apresentada sobre a espiritualidade e a relação com a natureza deste povo, um considerável potencial para fundamentar programas de educação ambiental ao atrelar sentimentos de respeito à ancestralidade, ao mágico e a personificação da natureza, podendo assim aproximar os Laklãnõ/Xokleng a tal ponto dos ambientes que, em determinados momentos, a separação 
entre o ser-pessoa e o ser-natureza se torna um dualismo indissociável. Esse contexto pode gerar um sentimento de identidade com a natureza, podendo consolidar-se como um fator essencial em processos de desenvolvimento desse povo, no tocante ao meio ambiente, destacando-se atividades de Educação Ambiental.

Outro tema de destaque são os recursos vitais coletados nos mais distintos ambientes. Os conhecimentos do povo estão relacionados aos recursos naturais utilizados como parte da cultura Laklãnõ/Xokleng. Entre os recursos vitais, estão aqueles relacionados com a alimentação, principalmente, os ligados à caça. No passado, havia muitos animais disponíveis para caça. A carne de animais nativos era um alimento muito importante, pois a maior parte da alimentação era à base de carne. Atualmente houve uma drástica diminuição dos animais de caça no território Laklãnõ/Xokleng. Essa redução ocorreu devido à diminuição das áreas de florestas, causando uma mudança drástica tanto na vida quanto nos hábitos alimentares da sociedade. O povo, que era migrante no passado, atualmente está confinado em um pequeno espaço de um pouco mais de 14 mil hectares de terras. Para os Laklãnõ/Xokleng, as ervas medicinais são de fundamental importância para a manutenção cultural com a natureza, pois elas oferecem um tratamento natural nos tratamentos de doenças e processos de cura.

Embora os conhecimentos dos Laklãnõ/Xokleng relacionados com o meio ambiente tenham sofrido considerável perda após o contato com a sociedade não indígena, o uso de recursos naturais está ainda presente como parte da cultura e da memória coletiva dessa sociedade.

\subsubsection{Elementos da geração, criação e transformação Laklãnõ em animais}

De 1983 a 1985, iniciei minha pesquisa, conversando diretamente com os anciãos sobre as crenças, o respeito à natureza e o que os animais representavam na cultura Laklãnõ/Xokleng. Na conversa citada, falaram-me sobre dois grupos que constituíram o povo Laklãnõ/Xokleng; um saiu da montanha, que são os $k l e \tilde{d} o^{19}$, e outro que emergiu da água, os vãjêk $y^{20}$, tendo sido estes que criaram os animais.

Entendemos que uma cultura envolve todo um contexto, tanto nas narrativas orais, crenças, língua materna, modo de viver, de pensar e de interagir com a natureza e o meio ambiente de onde a sociedade tira seu sustento, bem como o modo de ver o mundo de acordo

\footnotetext{
${ }^{19}$ klẽdo $\rightarrow$ klẽ 'montanha', do/dol $\rightarrow$ 'buraco ou gruta' .

20 vãjêky $\rightarrow$ os que emergiram da água.
} 
com a sua especificidade, sua organização social e política. Isso torna rica a cultura e a identidade étnica de qualquer sociedade. A partir desses aspectos, retomo um tema mencionado anteriormente sobre o papel que os animais representam na cultura Laklãnõ/Xokleng. Em minha pesquisa com os anciãos, na década de 80, era muito revelador os relatos de que os animais e plantas são iguais aos seres humanos, que falavam e se comunicavam com eles, tendo até nomes de seres humanos. Um exemplo é a 'bromélia', o nome dela é ãmẽdó, nome feminino. Este nome está vivo e é atualmente é usado como nome pessoal.

Segundo os relatos desses anciãos, no passado, houve uma grande revolução entre seres humanos e entre os maus espíritos. Com medo de serem atacados e devorados por esses espíritos, muitos dos homens e mulheres Laklãnõ/Xokleng se transformaram em seres da natureza, como pedra, árvores e plantas (epífitas, capim e as rasteiras), animais (mamíferos, repteis, anfíbios, peixes, insetos, abelhas, larvas, minhocas, vermes, moluscos, lesmas, caracóis), outros se transformaram em aves. Os que se transformaram em gug 'bugio' foram roncando, fazendo hooo, hooo..., subindo nas árvores; aqueles que se transformaram em txe 'quati' foram fazendo txég... txég..., subindo nas árvores; o kójãl 'macaco' foi fazendo ké...ké...ké..., subindo na árvore, e o zazan 'tatu' cavou a terra e entrou debaixo dela.

Em meio a tanto barulho e correria, um casal com sua filha chamada Ãmẽdo foram correndo fugindo desses espíritos maus. A menina cansou e ficou para trás, e os pais foram correndo e viram que ela estava bem lá atrás; e seu pai gritou para ela e disse: - Amẽdo hã ta ki mã kó lake u ve kũ ló ãmẽ kũ nẽ venh (Ãmẽdo procura aí uma árvore boa e fica ali com as mãos enfiadas no tronco dela). Assim, transformou-se em bromélia.

De acordo com esse relato dos anciãos, a ãmẽdo 'bromélia' também é conhecida como $k u$. Segundo o relato, as raízes que crescem sobre as árvores e que descem do alto das árvores são os cabelos da Ãmẽdo e dela é extraída a casca para tecer o arco e flechas e o cipó é utilizado na fabricação de cestos para guardar os pertences pessoais.

Considero relevante citar os conhecimentos no modo como os Laklãnõ/Xokleng veem o mundo e como nele interagem uns com os outros e com a natureza em que vivem e de onde tiram o seu sustento. Nesse aspecto, destaco novamente que o povo Laklãnõ/Xokleng acredita que toda a natureza e o que nela existe tem espírito e com a qual se comunicam através de um gesto ou um código de acordo com sua crença. 


\subsection{HISTÓRIA DE CONTATO DOS LAKLÃNÕ/XOKLENG COM OS NÃO ÍNDIOS}

Atualmente, o povo Laklãnõ/Xokleng, do estado de Santa Catarina, não passa de mais de 2.000 mil pessoas, mas sua história tem mais de 4 mil. São um dos povos mais antigos do Brasil e também foi um dos mais massacrados. Habitantes dos planaltos no sul do Brasil, no fim do século XIX, sofreram genocídio pelos chamados bugreiros, pela ignorância e pela ideia do progresso. Poucos restaram das diversas aldeias e poucas terras para os remanescentes; dos hábitos migrantes ao cerceamento imposto, os ritos e as tradições sacrificados no massacre, e doenças desconhecidas pelos Laklãnõ/Xokleng causaram-lhes muitas perdas. Diante do massacre sofrido e pela rapidez da perda dos parentes, os Laklãnõ/Xokleng decidiram por si próprios fazer contato com os brancos, a fim de poder criar os filhos.

Em conversa com um dos sábios Laklãnõ, segundo ele, um dia conversando entre eles, falaram um para o outro dizendo: 'vamos um dia fazer contato amigável com os brancos, igual como fizeram os vákáplág ${ }^{21}$, e quando fizermos o contato, nos tornaremos amigos deles e vamos morar junto com eles!

De acordo com o ancião, apesar dessa ideia de fazer contato, sempre continuavam a guerrear com eles. Um dia, proibiram os demais Laklãnõ de guerrearem. Assim procuraram um meio de fazer um contato amigável com eles para se tornarem amigos deles. Observa-se que a intenção era ter a liberdade de poder criar os filhos, porque se não os brancos iriam acabar com o povo ${ }^{22}$. Mesmo fazendo este acordo, segundo os sábios Voble ${ }^{23}$ e Kóvi $^{24}$, foram lá para matar o Jãgál ${ }^{25}$ 'Eduardo'. Foram à casa do Katagãl' mas ele não estava lá; já tinha ido embora. Então pegaram todas as coisas que estavam na casa (roupas e alimentos) e levaram para seus acampamentos, na mata, para os demais parentes. Na manhã do dia 22 de setembro de 1914, foram à casa buscar um cachorro que tinha ficado. Veja que o contato com o homem branco foi por causa de um cachorro.

Passados 100 anos de contato, até hoje ainda a voz solitária dos sábios anciãos persiste em manter vivos os cantos dos seus ancestrais e o grito de resistência do povo, de

\footnotetext{
21 vákáplág, nome dado pelos Laklãnõ/Xokléng a outros grupos indígenas que são Kaingáng.

22 Observa-se que os próprios Laklãnõ/Xokléng tomaram essa decisão, de ter este contato pacífico com a sociedade não indígena; não foram influenciados por ninguém. Mas sim pelo fato de estarem presenciando o extermínio do seu povo. Mas de acordo com alguns historiadores o povo Laklãnõ (Xokléng) foi pegado a laço pelo primeiro chefe do SPI.

23 Voble: nome masculino Xokléng.

24 Kóvi: nome masculino Xokléng

25 Jãgál, um dos nomes dado pelos índios ao primeiro chefe, Eduardo de L. e Silva H.
} 
forma que sejam transmitidos para as novas gerações. Apesar de quase serem silenciadas, essas memórias ainda despertam nos mais jovens o interesse de querer ouvir as histórias dos seus antepassados. Hoje não se canta mais em volta da fogueira; a música que fortalece a língua, a cultura e o sentimento Laklãnõ/Xokleng está hoje sendo ensinada nas escolas, com alunos e professores em sala de aula. Não só a música e a cultura ganham força, mas também o povo tem adquirido consciência e autonomia ao realizar atividades que promovem os saberes tradicionais que fortalecem a cultura tradicional.

A história da etnia Laklãnõ/Xokleng ultrapassa as casas de alvenarias em que moram atualmente ou as roupas que vestem. Não andam mais nus pelas florestas de araucárias já devastadas. Os homens não usam mais os botoques nos lábios, as mulheres não usam mais as vestimentas tradicionais confeccionadas com fibra de ortiga. As mudanças na sociedade Laklãnõ/Xokleng veem tanto a aculturação quanto a dinamicidade da cultura humana. A dinâmica da preservação e das mudanças que os indígenas enfrentam, como os problemas da descaracterização de suas tradições, nada mais é que um movimento que capacita o povo ao diálogo. Como outros povos, os Laklãnõ/Xokleng decidem por si e lutam pelos seus direitos dentro e fora das aldeias. São pessoas que se reconhecem e são reconhecidas pelas especificidades de sua etnia, pela resistência e pelo fortalecimentos de sua cultura.

\subsubsection{Localização da terra indígena do povo Laklãnõ/Xokleng e suas organização atual}

O povo Laklãnõ/Xokleng, atualmente, encontra-se somente no estado de Santa Catarina, onde está a sua única área indígena. O território é reconhecido como Terra Indígena Laklãnõ e está localizado cerca de 260 km a noroeste de Florianópolis e a 100 km a oeste de Blumenau, na região do Alto Vale do Itajai; sendo que suas terras se distribuem por quatro municípios catarinenses: José Boiteux, Vítor Meireles, Doutor Pedrinho e Itaiópolis. Cerca de 70\% da Terra Indígena está dentro dos limites dos municípios de José Boiteux (sudeste da Reserva) e Doutor Pedrinho (norte da Reserva).

Os Laklãnõ/Xokleng vivem em oito aldeias: Sede, Pavão, Barragem, Palmeirinha, Figueira, Coqueiro, Bugio e Toldo. Todas as aldeias têm autonomia política e uma organização própria e tem um cacique e um vice-cacique. Há também um cacique presidente (geral), que representa e dá a unidade das comunidades perante as instituições com as quais estabelecem relações políticas. Estes líderes são escolhidos por voto direto, têm mandato de 
quatro anos e direito à reeleição. Se a comunidade estiver descontente com algum dos líderes, pode destituí-lo mediante um abaixo-assinado e também mediante uma prova concreta com desvio de bens 'patrimoniais' da comunidade e assim seu vice assume ou outra pessoa escolhida pela comunidade para concluir o mandato.

Atualmente, entre os Laklãnõ/Xokleng, a maioria dos filhos, depois de casar, continua morando com a família dele ou dela. Parte dos domicílios abriga famílias nucleares, e também moram próximos uns dos outros, formando micro-aldeias. Cada vila é denominada pelos nomes das famílias extensas que as constituem. Assim, irmãos, cunhados, noras e genros vivem próximos uns dos outros.

Mesmo com a influência dos costumes adquiridos dos não indígenas, a noção coletividade que havia no grupo ainda permanece viva na prática. Isso indica que os novos padrões de vida adquiridos pela influência da cultura da sociedade não indígena, ao longo dos cem anos de contato, não se descaracterizaram muito, considerando os costumes da sociedade Laklãnõ/Xokleng, diferentemente do que está acontecendo com a língua materna. 


\subsubsection{Mudanças históricas do povo Laklãnõ/Xokleng pela Barragem Norte}

Ao longo da história povo Laklãnõ/Xokleng, desde o contato com a sociedade não indígena ocorrido em 1914, a situação se agravou na década de 70, com a implantação de uma barragem para conter as cheias do médio vale do Itajaí. (Ver foto)

Figura 2 - Barragem Norte

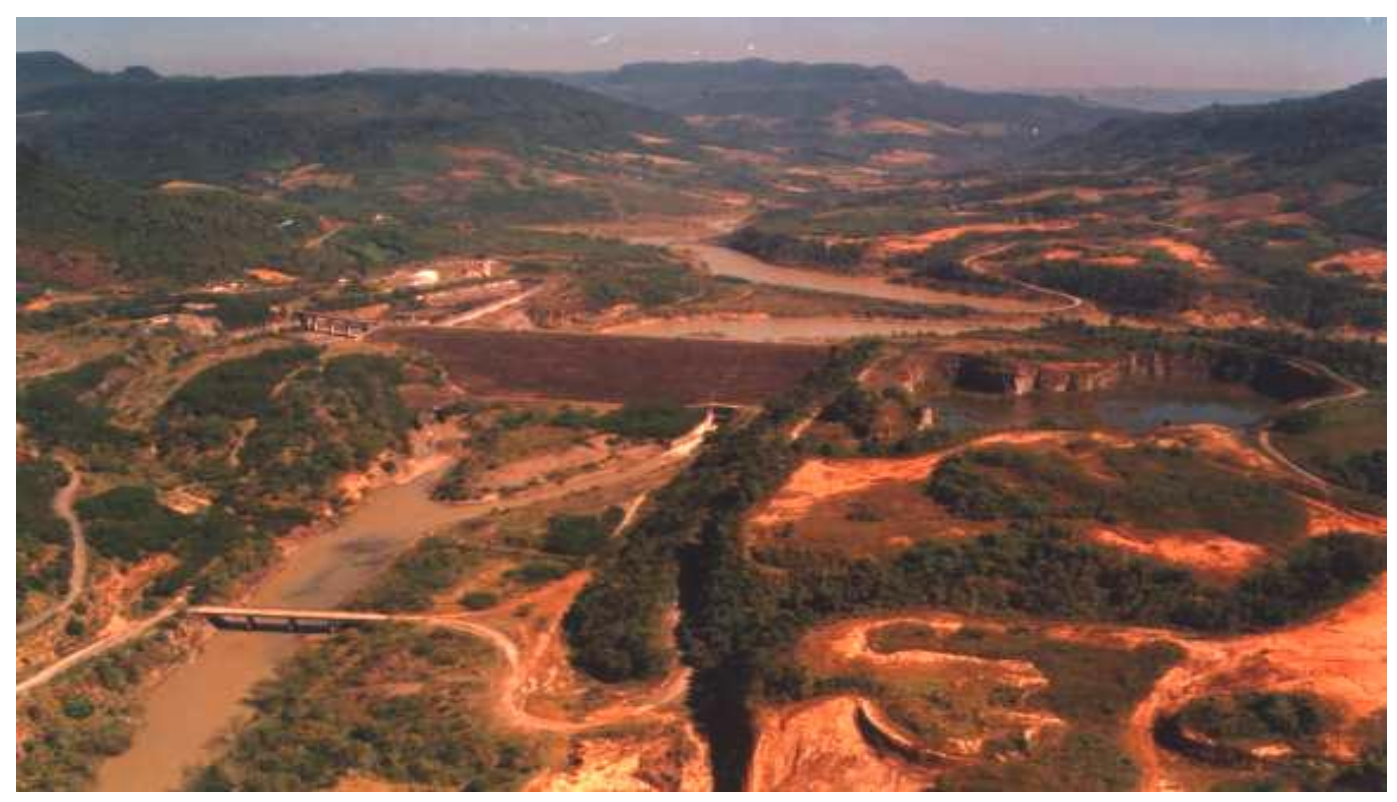

Fonte: arqiuivo pessoal de Nanblá Gakran

A Barragem Norte, como é conhecida, foi aprovada em 1974 pelo Presidente Ernesto Geisel, sendo que as obras iniciaram em 1976, sob a responsabilidade do extinto DNOS (Departamento Nacional de Obras e Saneamento). Praticamente dentro da Terra Indígena Laklãnõ, sua conclusão foi prevista para $1978^{26}$, sendo inaugurada simbolicamente em 1989 (pois não estava totalmente concluída).

\footnotetext{
${ }^{26}$ Devido a problemas técnicos e financeiros, sua conclusão nesse ano foi impossibilitada. Sendo que a primeira etapa foi concluída, em 1980, as obras ficaram paralisadas até 1983.
} 
Figura 3 - Barragem Norte

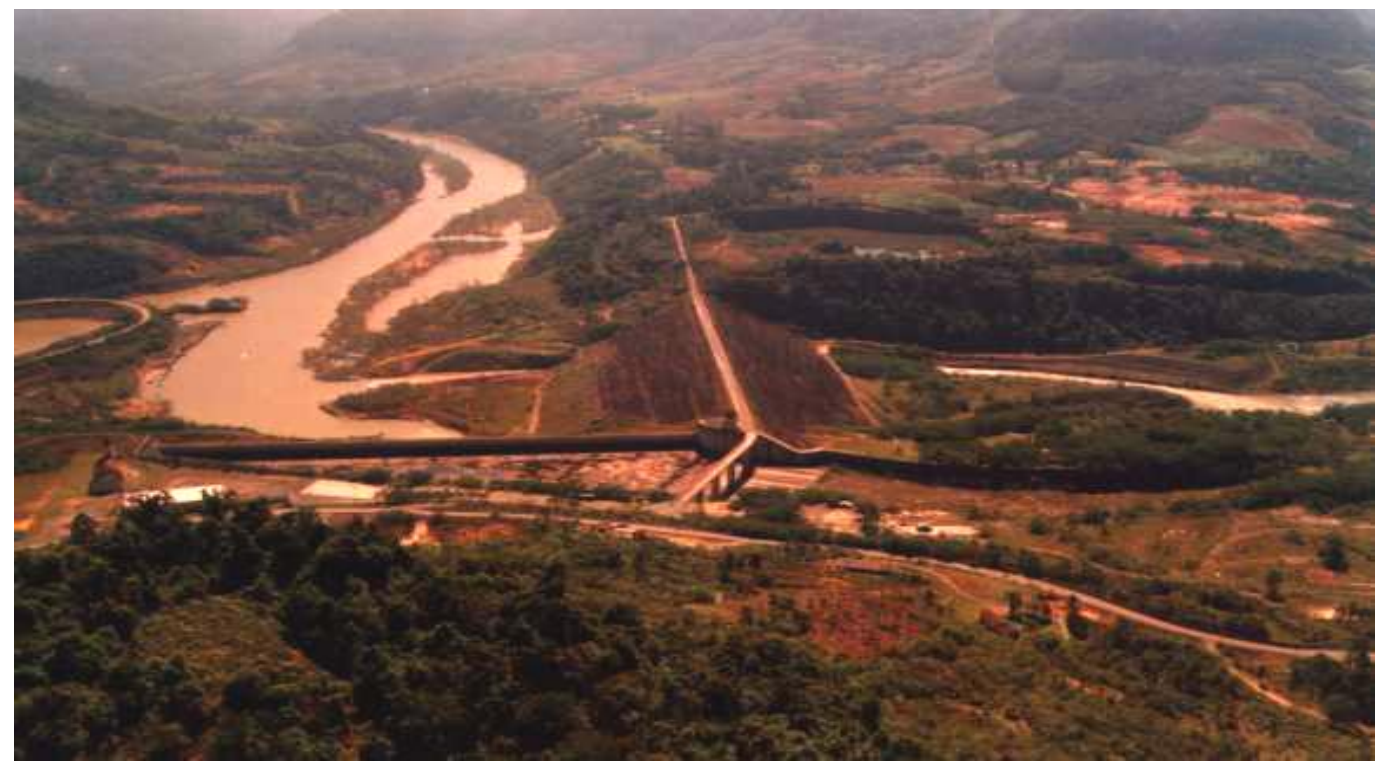

Fonte: arquivo pessoal de Nanblá Gakran

Os prejuízos econômicos, sociais e políticos causados pela construção da Barragem foram incalculáveis e acabaram levando os Laklãnõ a um empobrecimento progressivo. Com a construção da barragem e a vinda dos empregados houve um aumento significativo de casamento de não-índios com mulheres indígenas. Também com poucos recursos naturais, poucas terras agricultáveis, principalmente, por causa do relevo muito irregular e solo pedregoso, os Laklãnõ da Terra Indígena enfrentam dificuldades para tornar a área economicamente viável.

Figura 4 - Barragem Norte

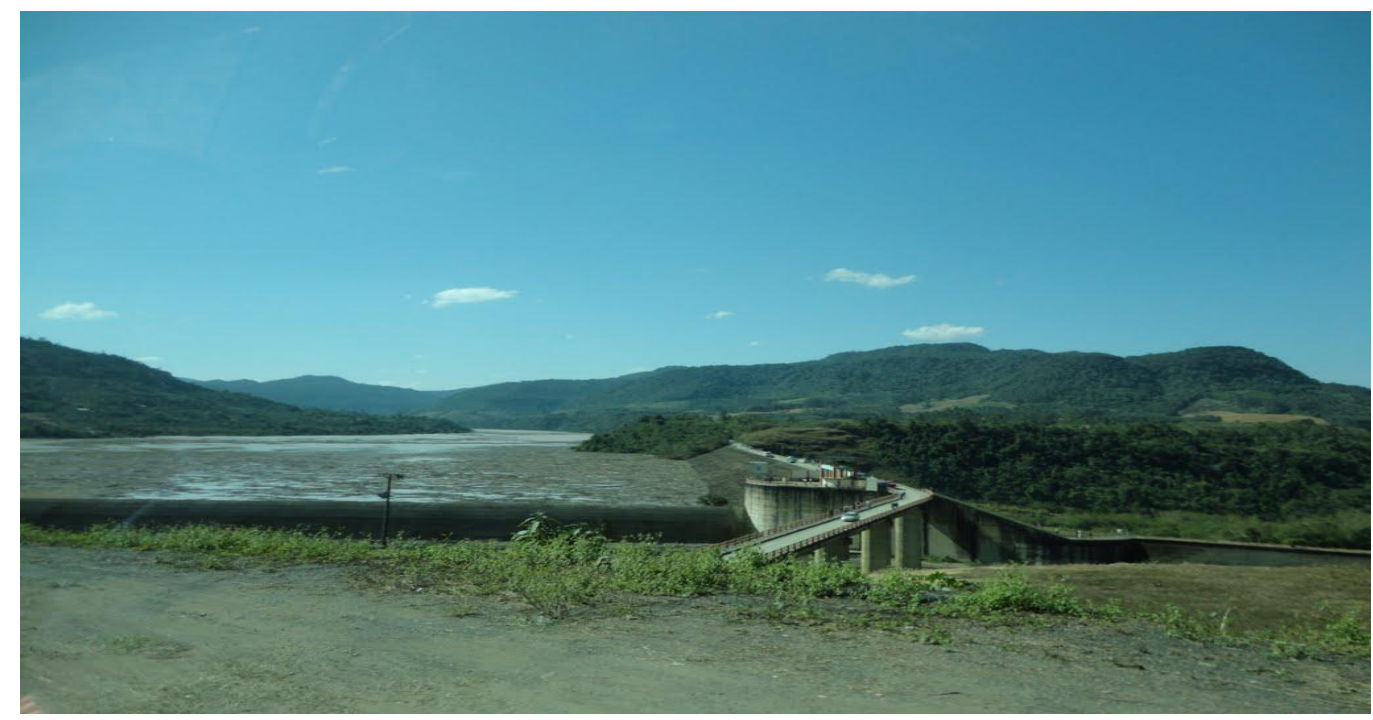

Fonte: arquivo pessoal de Nanblá Gakran 
Diante de inúmeras dificuldades, tem-se verificado, desde a década 1990, uma crescente migração de Laklãnõ para cidades próximas, deixando suas terras e indo morar em favelas nas cidade próximas, como Blumenau, Joinville, Itajaí, Rio do Sul, entre outras, submetendo-se à situação de carência total e desestruturando a comunidade. Com isso, foram deixando de falar sua língua materna e de praticar seus costumes, negando, assim, sua identidade nas condições de vergonha devido ao preconceito que sofrem.

Como mencionamos anteriormente, o contato intenso e até a dependência econômica em relação às outras culturas vêm forçando os Laklãnõ à adoção de padrões culturais externos. Nos anos 90, alguns de seus costumes foram deixados e, na época, muitos que não queriam mais se identificar como Laklãnõ/Xokleng, sentindo vergonha da sua condição e identidade. Isso significa que estavam passando por um processo dinâmico e imposto de fora. Tentaram adaptar-se a uma nova realidade étnica, mas não conseguiram, ou seja, são pessoas em crise de identidade étnico-cultural. Contudo, esse fato não significa que perderam sua identidade ou sua cultura, mas que estão sendo criados e recriados novos padrões de vida ao longo do tempo.

Em nome do progresso, a barragem foi construída sem pensar nas consequências que os Laklãnõ/Xokleng fossem sofrer e também adotando um modelo de civilização que priorizava o desenvolvimento econômico. Como proposta de expansão cada vez maior do modelo econômico, vários foram os projetos de desenvolvimento, os quais, além de outras classes minoritárias, acabaram afetando drasticamente o modo de viver da população indígena. Por falta de informação, os Laklãnõ/Xokleng não se opuseram inicialmente à construção da barragem, nem mesmo a FUNAI contestou, pois entendia que, como as terras pertenciam à União, poderiam dessa forma ser cedidas para outro órgão federal. Os Laklãnõ não tinham como saber da construção da barragem, porém a FUNAI deveria ter conhecimento que as terras que julgou ser da União foram tituladas a este povo em 1965, pelo governo de Santa Catarina.

A primeira catástrofe foi a enchente sofrida pelo povo, ocorrida no ano 1978, inundando as casas, roças, plantação de árvores frutíferas, pontes e estradas que pertenciam à comunidade, abrangendo cerca de 1.800 hectares de suas terras, sendo que estas eram as mais férteis e produtivas para o cultivo da agricultura da comunidade. Veja na foto a enchente: 
Figura 5 - Enchente no Rio Itajaí de 1978

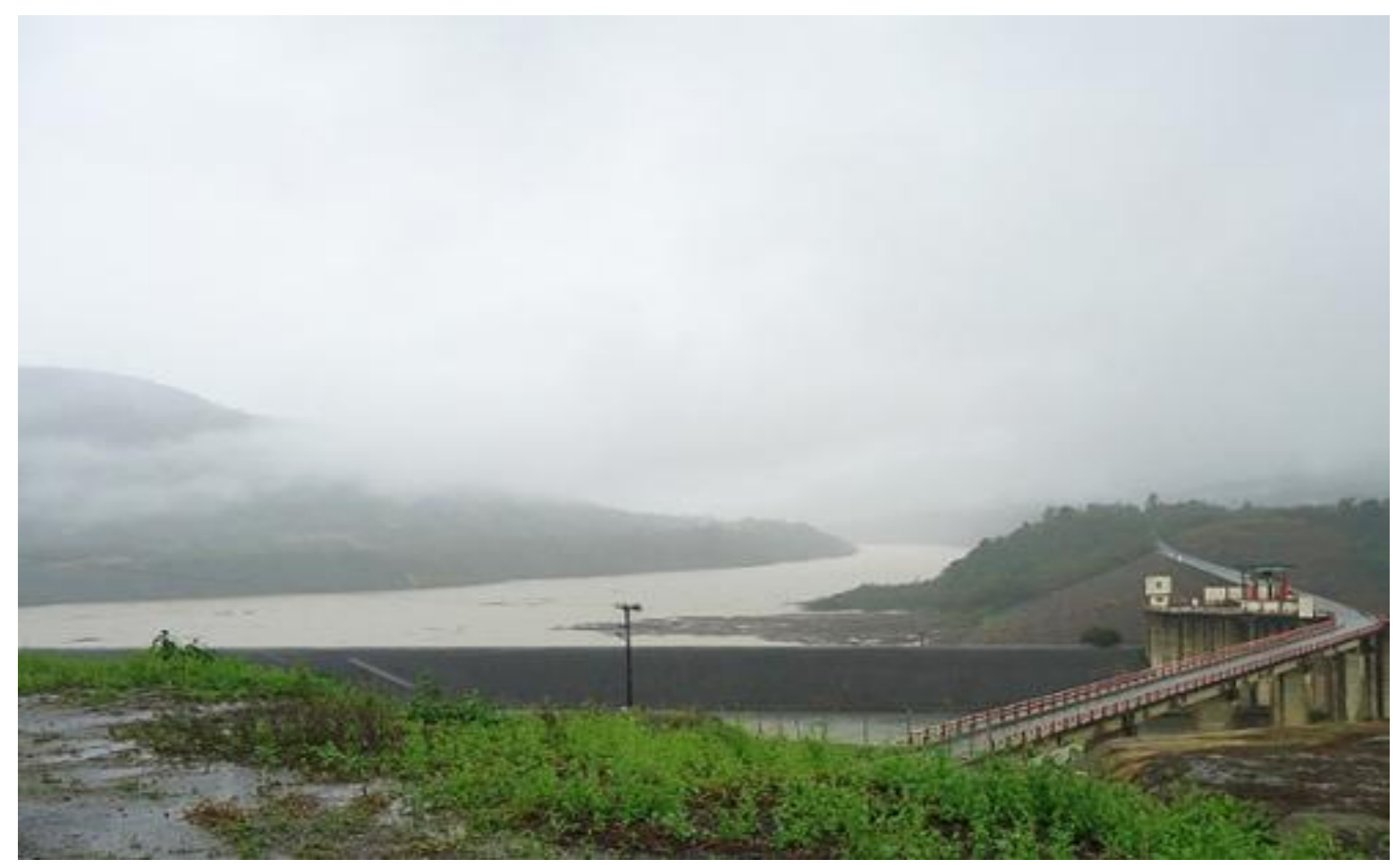

Fonte: arquivo pessoal de Nanblá Gakran

Cabe ressaltar que, com essa ação governamental, não apenas a população indígena e os colonos situados nas áreas próximas à barragem, mas também as populações regionais do Alto e Médio Vale do Itajaí, foram prejudicadas no âmbito econômico e social em decorrência das cheias. Diante dessa situação, não é o Estado que determina a sociedade, mas sim as relações que se dão na sociedade são as que determinam as ações do Estado. Na maioria das vezes, o Estado tende a responder aos interesses da classe economicamente dominante.

A construção da barragem implicou totalmente na impossibilidade do povo Laklãnõ/Xokleng continuar vivendo nas terras baixas e planas à beira do rio Itajaí do Norte, como era antes da construção da barragem. Veja na foto abaixo como fica a natureza depois da enchente na Terra Indígena Laklãnõ, nas partes baixas do rio. 
Figura 6 - Terra Indígena Laklãnõ

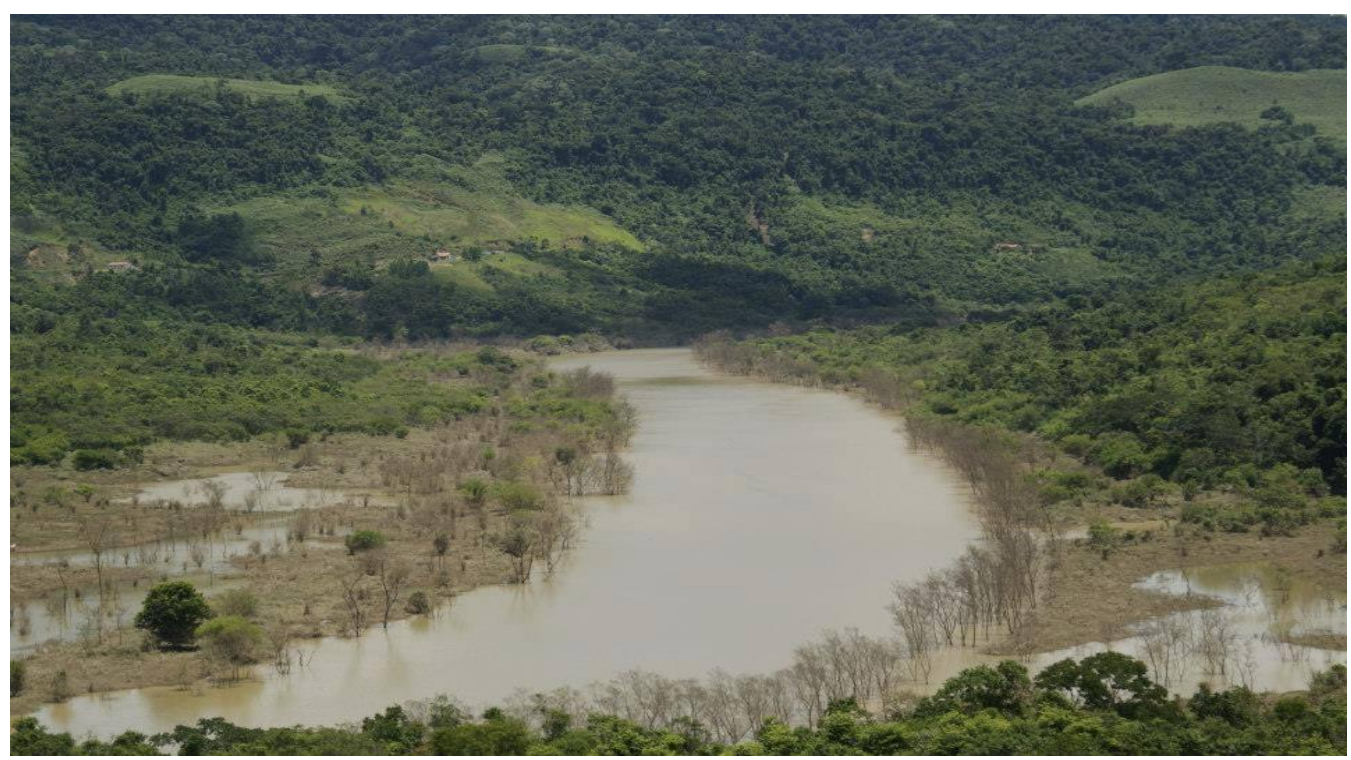

Fonte: arquivo pessoal de Nanblá Gakran

Como resultado desta destruição histórica, os Laklãnõ foram se deslocando para o alto dos morros, onde os espaços são limitados para ocupação humana e pouco férteis para o cultivo da agricultura.

Em relação à barragem, outro aspecto apontado como consequência foi o de que tal fato provocou a divisão da Terra Indígena em várias aldeias. Consequentemente, também alterou a estrutura política do povo, pois anteriormente a tal fato existia um único representante ou um cacique. Atualmente, cada aldeia tem seu representante por região devido a distância que os separa em todo o território Laklãnõ.

Muitos foram os prejuízos causados com a construção da barragem, na década de 1980. Os Laklãnõ, com apoio jurídico, de ONG’s, Universidades, entre outras instituições preocupadas com a situação, iniciaram a luta para assegurar a indenização das terras ocupadas pela barragem, mas que até agora não receberam ainda. Em 1986 receberam através da FUNAI uma única quantia como indenização ${ }^{27}$ das benfeitorias e árvores frutíferas.

Baseados em documentos e estudos feitos, constatamos que a barragem construída próxima a Terra dos Laklãnõ não foi a única, mas também outras foram construídas próximas a terras indígenas. Podemos tomar como exemplo, a construção da Usina Hidroelétrica de Tucuruí, em Tocantins, que, além da depredação da natureza, ameaçou os índios Parakanã,

27 Os Xokléng foram indenizados apenas pelos danos causados pelas enchentes, sendo que não foram indenizados pelas terras. 
pelo represamento das águas e consequente formação de um lago, e foi só em sua fase de conclusão que a FUNAI se preocupou com a sobrevivência dos mesmos.

Questionamo-nos se é coincidência que as barragens e grandes projetos que dispõem de grandes investimentos, sejam construídos próximos a terras indígenas, as quais, segundo a lei, pertencem à União e sobre qual é realmente a autonomia que os povos indígenas têm sobre 'suas terras'.

\subsection{HISTÓRIA DA EDUCAÇÃO ESCOLAR ENTRE OS LAKLÃNÕ}

A educação escolar indígena historicamente foi marcada pela visão assimilacionista que orientava as políticas indigenistas oficiais. Neste contexto, a educação escolar indígena no período colonial era promovida por religiosos. Esta prática prosseguiu desde a época do império, com a finalidade de catequisar e civilizar os indígenas. No entanto, a educação escolar indígena, por seu caráter diferenciado, foi entregue ao órgão oficial de proteção aos índios, do SPI - Serviço de Proteção aos Índios, criado em 1910. A intenção dessa 'escola' era pautada na aculturação e assimilação, voltada para a promoção do desaparecimento dos contingentes indígenas, através de sua incorporação à sociedade dominante.

Segundo Santos (1975), o SPI, a princípio, apreendeu esforços no sentido de atender os indígenas em seus pleitos, cumprindo importante função de conter o massacre que ocorria por conta de expansão colonialista, mas aos poucos perdeu sua estrutura, transformando-se em instrumento de submissão e cerceamento. Desta forma, em 1967 foi substituída pela então Fundação Nacional do Índio/FUNAI, criada durante o regime militar, que também direcionou sua atuação para a consecução dos objetivos integracionistas e desenvolvimentistas do Estado brasileiro. De acordo com o mesmo autor, a expansão sistemática de educação promovida por esse órgão se deu segundo os moldes da sociedade nacional envolvente e durante muito tempo não se fez qualquer avaliação crítica quanto às funções e possibilidades da educação formal para os indígenas. A partir da década de 70, surgiram organizações indigenistas não governamentais e com isso deu-se início à articulação e formação do movimento indígena organizado no Brasil, realizando discussões acerca dos direitos das populações indígenas e das diferenças do ensino bilíngue, que é a forma de respeitar o patrimônio cultural das comunidades indígenas (ESPEC 47, da Lei nº 6.001/1973 - Estatuto do Índio). Segundo Santos (1975), na prática, a educação bilíngue firma-se como tática para submissão indígena, garantindo os interesses do Estado brasileiro, tendo como parceria as missões religiosas que 
desempenharam papel decisivo na implantação de um modelo educacional que serviu de instrumento das políticas oficiais de integração.

Em 1988, como resultado de anos de luta e mobilização empreendidas pelos povos indígenas e organizações de apoio às causas indígenas, registra-se um avanço no entendimento sobre o papel da educação indígena, como a Constituição Federal, que reconhece aos povos indígenas o direito e as diferenças culturais. No artigo 231 da referida Constituição Federal, reconhece as populações indígenas, sua organização social, costumes, língua, crenças e tradições, assegurando também a estas comunidades o uso de suas línguas maternas e os processos próprios de aprendizagem (ESPEC 210), o que é reforçada pelo artigo 167, inciso $2^{\circ}$ da Constituição do Estado de Santa Catarina.

No estado de Santa Catarina, registra-se a expansão do sistema de escolarização em áreas indígenas a partir dos anos 60, sob a responsabilidade da FUNAI. A partir de 1994, intensificam se as discussões na SED - Secretaria Estadual de Educação - e inicia-se a estruturação do Núcleo de Educação Indígena (NEI), responsável por propor diretrizes educacionais e executar ações com a finalidade de efetivar uma proposta de educação que contemple os princípios da especificidade e diferenças, interculturalidade e bilinguismo. No entanto, atendendo à demanda de várias instituições e também das próprias comunidades indígenas, é oficializado o NEI em 1996, diretamente vinculado à diretoria de Ensino Fundamental.

A nova lei de Diretrizes de Base da Educação Nacional de 20 de dezembro de 1996 contempla a temática indígena nos currículos do Ensino Fundamental e Médio (ESPEC 26, inciso $4^{\circ}$ ), bem como a garantia da utilização da língua materna e dos processos próprios de aprendizagem nas comunidades indígenas.

Para tanto, atualmente, embora se registrem alguns avanços tanto no nível nacional quanto estadual, o que ainda ocorre é a transferência dos currículos oficiais, totalmente em português. Aos poucos, isso está fazendo com que a cultura e as línguas indígenas sejam sistematicamente silenciadas e desvalorizadas, até serem substituídas pela chamada língua e cultura nacional. Isso tem confrontado com os ideais de autonomia dos povos indígenas, que almejam uma educação escolar que esteja a favor dos seus interesses reais atuais e históricos. 


\subsubsection{Primeira escola entre o povo Laklãnõ/Xokleng}

No final dos anos 30, mais especificamente em 1938, foi implantada pela primeira vez uma escola que ensinou a língua portuguesa em uma comunidade Laklãnõ/Xokleng pela iniciativa dos próprios indígenas. A intenção deles era de uma escola que pudesse ensinar os jovens e as futuras gerações a ler e escrever. De início, o chefe do SPI, Eduardo de Lima e Silva Hoeran, não gostou da ideia, pois o mesmo já previa que, se os indígenas tivessem contato permanente com o ensino da língua portuguesa e se aprenderem a falar o português razoavelmente, recusaria sua própria língua materna. Mas diante de muitas insistências dos próprios indígenas, o chefe acabou aceitando a ideia. A partir daquela decisão e da aceitação do chefe, foi implantada a primeira escola para o povo Laklãnõ/Xokleng na própria Terra Indígena. Assim, o primeiro professor foi um polonês chamado Mieczyslaw Brzezinski que, na época, estava entre os Laklãnõ/Xokleng na aldeia. Como foi mencionado anteriormente, o chefe Eduardo não gostou da ideia, mas acabou aceitando. Segundo Santos (1997), ele não só apoiou como parecia vigiar a escola o tempo todo.

No início dos anos 40, os Laklãnõ/Xokleng construíram um novo prédio de escola, onde o próprio Mieczyslaw, mais conhecido pela comunidade como 'maestro', alfabetizou diversos indígenas na língua portuguesa. Santos (1975) afirma que a escolarização sistemática havia começado na década de 40, mas não existiam objetivos fixados ou discussões pelo órgão responsável, o SPI (Serviço de Proteção aos Índios), a respeito da educação formal entre os indígenas, apesar de que já se contabilizava pelo menos uma escola na reserva. Para Santos (1975), apesar do resultado desta escola ser quase nulo, ou seja, quase sem efeitos, ela continuava existindo na contabilização do órgão responsável. O autor ainda afirma que poucos índios alcançavam sucesso ao ser alfabetizados e, por outro lado, acabavam sendo usados para lecionarem, a fim de justificar que a educação escolar formal entre os indígenas estava dando resultado positivo.

Desde o início da escolarização dos Laklãnõ, vários professores voluntários atuaram na alfabetização de crianças e adultos. Ao longo da história da criação da escola entre os Laklãnõ, no ano de 1955, foi contratado o primeiro professor indígena, que se chamou Lino Nunc-Nfôonro, tendo trabalhado até o fim do ano de $1977^{28}$. Depois disso, vários professores não indígenas foram trabalhar na escola dos Laklãnõ.

\footnotetext{
28 Falecido em 12 de junho de 2001, é lembrado com saudades pela comunidade e por celebridades como Silvio Coelho dos Santos, que esteve presente em seu enterro. Informações prestadas por Genice Fiamoncini.
} 
A seguir, para justificar o que foi mencionado anteriormente referente à implantação da primeira escola entre o povo Laklãnõ/Xokleng, mostrarei parte das entrevistas coletadas dos próprios alunos dessa primeira escola e também o depoimento de um dos sobreviventes que participou da implantação da primeira escola e que o próprio conversou com o chefe do SPI a fim de convencê-lo para que a escola fosse implantada.

\subsubsection{Memória dos alunos da primeira escola entre os Xokleng, na década de 30}

Como foi dito, serão mostrados os relatos, na íntegra, coletados de pessoas que participaram desta iniciativa e de alunos da primeira escola, quando foi implantada em 1938. Por razão ética, não serão revelados os nomes dos entrevistados, mas serão usadas as letras como, por exemplo, "D" e "V" para facilitar a leitura. Na época da pesquisa, no ano de 2000, tivemos oportunidade de entrevistar " $\mathrm{D}$ ”, que foi uma das pessoas que participou ativamente desta iniciativa de implantação da primeira escola entre o povo Laklãnõ/Xokleng. Já "V”, era um dos primeiros alunos daquela escola no ano de 1938.

De acordo com o entrevistado em 1938, veio um polonês, foragido da guerra, passou pela Argentina, ficando lá por um tempo e depois veio para o Paraguai e de lá para o Brasil. Chegando ao Brasil, foi conversar com o diretor do SPI no Rio de Janeiro, na época, capital do Brasil, para pedir autorização para o chefe do SPI para conhecer a nova terra descoberta, que seria na época esta reserva indígena. O diretor do órgão autorizou Mieczyslaw Brzezinski a conhecer a terra, e o mesmo veio morar entre os Laklãnõ/Xokleng. Segundo "D”, quando o polonês Mieczyslaw chegou ao posto indígena e foi conversar com o chefe Eduardo, perguntou se poderia ficar ali com os indígenas, e o chefe acabou aceitando. O mesmo afirma que o polonês foi morar com os Laklãnõ/Xokleng e que andava com os mais velhos, caçava com eles e devido ao contato permanente, ele acabou aprendendo a falar a língua Laklãnõ. E eles também viam todo o jeito dele, porque andava junto com eles caçando pela mata. $\mathrm{O}$ mesmo afirma que ele era chamado pelos Laklãnõ com o nome de 'maestro'. Segundo o entrevistado, o 'maestro' falava com os livros grandes que tinha em seu poder e isso despertou um interesse de aprender a ler com ele e assim falar com os livros. "D" acha que o 'maestro' via a necessidade e a dificuldade deles de se comunicarem com os brancos, foi por isso que lhes mostrava os livro e os desenhos que tinha ali, despertando, assim, ainda mais o interesse deles. 
De acordo ainda com "D”, eles mesmos decidiram sozinhos implantar a nova escola, porque viam os brancos nas localidades vizinhas terem escola onde os filhos destes aprendiam a ler e a escrever. Então, um dia resolveram falar com o 'maestro' para pedir a ele para ensinar a ler e a escrever como os brancos. O mesmo ainda afirma que foram em quatro pessoas falar com o 'maestro' e que, ao chegarem lá, disseram para ele: '...nóis viemo aqui pedi pro senho ensina nóis aprende le e escreve como o senho faz, será que o senho faz isso?' “D” completa falando que o 'maestro' olhou para os quatros e balançou a cabeça e disse para eles: 'Eu faço, porque sou acostumado a fazer isso, lá na minha terra eu fazia isso com as pessoas grandes, se quiserem que eu dê aula para vocês, vão pedir licença para o chefe e ai, eu vou dar aula para vocês'. "D” relatou que depois que o 'maestro' aceitou a ideia, foram então falar com o chefe para pedir licença.

“D” completou dizendo que ele mesmo foi falar com o chefe Eduardo junto com mais três pessoas e quando os quatros chegaram à casa do chefe, ele perguntou: $O$ que vocês querem? Então o próprio “D” respondeu para ele: 'nois viemo aqui pra pedir pro senho que nóis queremo uma escola para os adultos e pra nossas crianças tamém'. Novamente o chefe perguntou. Quem falou isso para vocês? "D" respondeu novamente dizendo: 'Nóis que pensamo nisso, porque nóis tamo vendo os branco estão sabendo le e conversa bem e manda carta e nóis estamos vendo isso e nois vamo faze, por isso que viemo pedi licença, o senho resolva isso para nóis, porque precisamo te isso, pois temo muita criança, são bastante e nóis queremo que eles aprende le e falar, por isso que viemo pedi'.

De acordo com o "D", o chefe Eduardo ficou pensando até que disse: E vocês vão fazer uma casa para ser escola? "D” respondeu: não, nóis temo aquela casa, salão para dança, vamos usa aquele pra escola por enquanto, até que vamo faze uma escola'. O chefe perguntou novamente: Quem vai dar aula para vocês e quem vai pagar o trabalho desta pessoa? "D” falou para o chefe: 'nóis vamo pedi pro 'maetro' dar aula pra nóis, ele disse que não vai cobrar nada, vai da pra nóis de graça'. Diante de muita insistência o chefe acabou aceitando e disse para eles: Então poDEMfazer, diga para o maestro que ele pode dar aula para vocês, mas antes disso, pede para ele vir conversar comigo.

Segundo "D”, o chefe não gostou muito da ideia e, antes de autorizar, falou muito para eles sobre as futuras consequências e depois autorizou. Para " $D$ ", o chefe não queria que os índios aprendessem a ler e nem escrever, porque ele já previa o que iria acontecer quando os índios aprendessem a ler e a registrar o próprio nome, estariam negando sua identidade como índio. "D" ainda afirma que, depois que foi autorizado pelo chefe, voltaram novamente 
a falar com o 'maestro'. Disseram para ele que o chefe aceitara a ideia de fazer escola, mas antes de iniciar ele pedira para o 'maestro'ir lá conversar com ele.

De acordo com “D”, quando o 'maestro' falou sobre a aula com o chefe e ele perguntou: Quem vai pagar teu serviço? E depois não tem casa para você dar aula e não tem nem quadro, o que você vai fazer? Então o 'maestro' respondeu: Não vou cobrar nada do meu serviço, vou trabalhar por minha conta própria e também podemos usar aquela casa grande que é salão para fazer a escola e o quadro e os bancos eu vou fazer ou dar jeito. E o chefe Eduardo então respondeu: Então se é assim, você pode começar a aula.

Assim, conforme o relato de “D”, quando o 'maestro' voltou da casa do chefe, pediu para que todos, junto com ele, arrumassem a casa que era o salão e fazer os bancos; fez um quadro e arrumou cadernos e assim iniciou-se a aula. " $D$ " fala que o professor 'maestro' deu aula para os grandes e até para as crianças durante seis meses. Para os grandes, a aula era de madrugada, mais ou menos das 3 horas até às 7 horas da manhã, porque durante o dia, os adultos trabalhavam na roça. Em seguida, às 7 horas da manhã, começava a aula das crianças até o meio dia. Assim, iniciou-se a primeira escola entre os Laklãnõ/Xokleng.

Depois desse tempo, o 'maestro' retornou para sua terra e como o chefe do posto acabou gostando da iniciativa, não quis deixar a escola por muito tempo parada. Assim, chamou outro professor para dar aula no lugar do professor "maestro' para as crianças. "D" fala que já depois de ter iniciado as aulas com outro professor, o 'maestro' chegou de volta de sua terra. E vendo outro professor no seu lugar, o 'maestro' ficou muito triste e ficava cantando sozinho as músicas que ele mesmo fez e também cantava as cantigas do Xokleng que ele aprendeu com os mais velhos. Segundo "D", vendo que outro professor tomou seu lugar, o maestro se suicidou, enforcando-se na própria escola que ele mesmo fez com os índios. Fala-se que os Laklãnõ/Xokleng choraram durante uma semana a morte do professor 'maestro', porque ele era muito amigo deles e, segundo " $D$ ", ele foi a pessoa que trouxe luz para eles. De acordo com o relato de "D”, depois do professor 'maestro', vários outros professores foram lecionar, mas todos faziam um trabalho voluntário até que, em 1955, o primeiro professor indígena foi contratado pelo SPI.

Já o entrevistado "V", que foi um dos primeiros alunos, afirma que, na época, não havia merenda na escola para as crianças comerem. Ele complementou dizendo que os próprios índios plantavam milho, feijão, arroz e davam para os professores fazer como merenda para as crianças comerem. Também eles mesmos davam mel de abelha para as crianças comerem. "V" fala que os professores mandavam fazer farinha de milho no moinho 
para preparar a polenta para as crianças comerem com o feijão. O próprio professor também cozinhava o arroz para as crianças comerem como merenda.

"V" relata que o SPI e até mesmo a FUNAI nunca assumiram um compromisso com a escola para que pudessem melhorar suas condições. Os professores eram colocados na escola, mas nunca ninguém orientava para melhorar a atuação deles. Da mesma forma, fala-se que nunca fizeram reunião com os professores e que os mesmos davam aula por conta própria. "V" ainda completou sua fala dizendo que aquele índio que aprendia a ler e escrever um pouco, o chefe o colocava no lugar do professor para dar aula quando aquele professor faltava na escola. Segundo o entrevistado, agora é diferente porque atualmente se fazem reuniões para os professores planejarem como trabalhar.

"V" afirma também que o SPI e FUNAI, não fizeram escola, que a escola nunca teve prédio próprio; hoje as escolas têm prédio próprio. Conforme esse relato, os professores davam aula no salão, onde os índios faziam festa, como sala de aula. "V" ainda completou dizendo que o chefe Eduardo nunca se preocupou em fazer um prédio próprio para ser escola. Depois de algum tempo, os próprios índios fizeram um prédio novo para ser escola, onde o professor 'maestro' se enforcou. Uma das razões para o suicídio do professor 'maestro' foi que ele não recebia nada, passava fome e não pedia ajuda para ninguém, já que sua família morava na Polônia.

Do ponto de vista do entrevistado, o SPI não cuidava da escola, mas depois que passou para a FUNAI a escola melhorou um pouco e assim começou a vir material escolar e merenda, já que isso anteriormente não existia. No entender de "V", o que a educação escolar trouxe de bom para os Laklãnõ/Xokleng foi a aprendizagem da leitura e escrita para entender bem o português para defender seus direitos como índios.

Por outro lado "V" lamenta dizendo que: a escola fez o índio esquece de ser índio, quando aprendeu le e fala portugueis, pensou que ia ser igual o branco, assim foi deixando de fala sua língua, seu costume, e tamém tem vergonha de dize que é índio e começou pega costumes do branco, quando nasce fio, não fala mais seu idioma com ele, assim ensina fala o portugueis. Não respeita mais a orDEMdado pelo cacique, nem a justiça lá fora, no fim o índio não é mais índio e nem é igual ao branco, ele não é mais nada. O Chefe Eduardo já pensou nisso antes, por isso que ele não queria escola aqui dentro, mais nóis que pedimo, por isso ele aceitou. Eu acho que o índio deve ir pra escola e aprende le e escreve mas não precisa deixa de seu costume, as cantigas dos mais veio, o idioma.

Para "V", os jovens devem estudar, mas não evem deixar de lado os costumes dos seus antepassados. O mesmo completou dizendo que está muito preocupado com o que está 
acontecendo com os jovens e a comunidade, pois estào perdendo sua história: ' to vendo que tamo se acabando, os mais veios que sabia de toda nossa história já estão terminando, isso me preocupa muito, mas nunca tinha ninguém pra fazer este trabaio, de escreve nossa historia, porque se não vai acabar, vai termina nossa língua, não sei quem vai faze isso e assim ensina nossos fios na escola. Governo podia nóis ajuda e assim faze livro da nossa historia e da nossa língua, assim não vai terminar mais e vai continuar vivendo'.

É marcante nos depoimentos o fato de se atribuir quase exclusivamente à escola ser a única responsável pela perda dos costumes e das tradições, mas ao mesmo tempo os conhecimentos transmitidos os permitiram exigir seus direitos. No entanto, deu-nos a entender também que a leitura, a escrita e a matemática abriram as portas para o mundo externo. Diante dessas falas podemos perceber que a perda dos costumes e a desvalorização da própria cultura é a influência negativa que foi citada com mais ênfase desde a implantação da primeira escola entre os Laklãnõ/Xokleng. Mesmo levando em conta que a implantação da escola surgiu em comum acordo com os próprios indígenas, percebesse que há um arrependimento entre o povo pela decisão tomada na época, também dá a entender que a educação escolar desestruturou a identidade cultural étnico deste povo.

Da mesma forma percebemos também que há uma preocupação muito grande sobre a importância de ter aula no próprio idioma, para que a língua não venha a ser esquecida no futuro e também deixa-la registrada em livros. Do ponto de vista dos entrevistados, se continuar desta maneira, o índio ficará igual aos não indígenas e poderá perder seus direitos e suas terras. Notamos que a preocupação com o resgate da história e a revalorização dos costumes e da língua está presente no depoimento dos entrevistados. Para que isto venha acontecer, toda a comunidade juntamente com as lideranças devem articular-se junto aos governos, políticos e ONG's para conseguir um meio de registrar as histórias do povo Laklãnõ/Xokleng.

É importante frisar novamente que a decisão de construir uma escola foi dos próprios indígenas, influenciados pela presença do professor Mieczyslaw Brzezinski, do SPI. Isso indica que, a partir daquele momento, houve um contato permanente com a sociedade não indígena e a presença constante da educação escolar, desencadeando um processo acelerado de perda dos costumes e do idioma Laklãnõ. Em função da presença de instituição escolar, tal como ela é concebida na sociedade não indígena, em função do ensino de língua portuguesa, a cultura e a língua dos Laklãnõ foram desvalorizadas e substituídas pela chamada língua e cultura nacional, ou seja, deu-se início ao processo de perda de uma cultura milenar, que ao longo do tempo era transmitida de pai para filho. Quero destacar que a escola não é a única 
responsável pela desmotivação da comunidade e pela perda dos costumes, mas é uma das instituições que ao longo do tempo interferiu, fazendo o povo esquecer e deixar seus costumes de lado.

Um segundo fator foi a vinda do cristianismo para dentro da comunidade e também o contato permanente com a sociedade não indígena que as igrejas proporcionaram. E um terceiro fator também muito marcante e ainda presente é a influência da política de fora para dentro da comunidade, trazendo novas divisões e disputas internas. Isto significa que no passado, ao longo da história do pré-contato, havia muitas práticas voltadas à coletividade no grupo, as quais devido à influência da política têm sido pouco praticadas.

\subsubsection{Educação escolar entre os Laklãnõ/Xokleng no período de 1990 até 2015}

Ao longo da história da educação escolar entre os Laklãnõ, muitos foram os avanços conquistados, apesar de que nos últimos anos houve um descuido da parte do governo do Estado de Santa Catarina pela educação indígena. No início da década de 1990, a Terra Indígena Laklãnõ possuía oito escolas distribuídas em cinco aldeias, atendendo a um total de 142 alunos entre Xokleng, e alguns descendentes Kaingáng e Guaraní, todas com ensino fundamental de $1^{\mathrm{a}}$ a $4^{\mathrm{a}}$ séries. As escolas distribuíam-se da seguinte maneira: 3 escolas na Aldeia Sede (Escola Isolada Municipal Congroi Reschidn Mongono, Escola Isolada Indígena Duque de Caxias e Escola Isolada Municipal Voia Criri), 2 escolas na aldeia Bugio (Escola Isolada Jango Priprá e Escola Isolada Indígena Vanhecu Patté), 2 escolas na Aldeia Figueira (Escola Covi Patê e Escola Isolada Brasílio Priprá) e 1 escola na Aldeia Toldo (Escola Isolada Luiza Meirin Nfoonro).

Em 1994, foi implantado o ensino da língua materna Xokleng em cinco escolas, como experiência, ministrado pelo professor Nanblá Gakran. O professor era contratado pela Secretaria de Estado da Educação do Estado de Santa Catarina. Depois de dois anos foram contratados mais professores para lecionar a língua materna em outras escolas.

Depois de muita luta dos Laklãnõ por uma educação de qualidade para a comunidade, o governo do Estado de Santa Catarina, em 2003, elaborou em conjunto com a comunidade um projeto para construção de uma Escola com Ensino Fundamental e Médio para atender as especificidades desta comunidade. Depois do projeto pronto e aprovado foram iniciadas as obras da construção da escola. A escola foi concluída no primeiro semestre do ano de 2004 e foi dado o nome de Escola Indígena de Educação Básica Laklãnõ. As atividades foram iniciadas no segundo semestre do ano de 2004. Desse modo, seis escolas 
isoladas no interior da Terra Indígena foram nucleadas na nova escola (Escola Covi Patê, Escola Isolada Brasílio Priprá, Escola Isolada Municipal Congroi Reschidn Mongono, Escola Isolada Indígena Duque de Caxias, Escola Isolada Municipal Voia Criri e Escola Isolada Luiza Meirin Nfoonro) A Escola I.E.B. Laklãnõ está sendo mantida pela Secretaria de Estado da Educação de Santa Catarina.

Atualmente, os Laklãnõ têm uma escola onde os jovens concluem seus estudos de Ensino Médio na própria Terra Indígena, sem precisar sair da aldeia para estudar. A língua materna está sendo ensinada nessa escola desde a alfabetização até o Ensino Médio. Vários jovens que concluíram o ensino médio estão curando cursos superiores em universidade particulares próximas à Terra Indígena e outros cursando na Universidade Federal de Santa Catarina.

No ano de 2005, foi aprovado o Parecer 282, uma Resolução das Escolas Indígenas do Estado de Santa Catarina, para as três etnias existentes no estado: Guaraní, Kaingáng e Xokleng. Na região sul, Santa Catarina é o único estado que possui uma matriz curricular para todas as escolas indígenas existentes.

Todos os funcionários da Escola I.E.B. Laklãnõ são indígenas, desde os funcionários de serviços gerais até a Direção são índios da etnia Laklãnõ/Xokleng. A maioria dos professores possui Ensino Superior nas áreas específicas em que atuam, como Letras, História, Geografia, Matemática, Ciências Biológicas, Pedagogia e outros em Licenciatura Intercultural Indígena. Há um projeto para ser implantado um campus de uma Universidade particular dentro do território da Terra Indígena Laklãnõ.

Em 2010, na aldeia Bugio, a Escola Isolada Indígena Vanhecu Patté, foi ampliada para ser uma escola de Ensino Fundamental e Médio, devido à distância dos alunos indígenas, que têm que se deslocar para sair da aldeia para concluir os estudos, porque a aldeia é uma das mais distantes no interior da Terra Indígena. A escola passou a chamar-se Escola Indígena de Educação Básica Vanhecú Patté. Todos os funcionários da escola são indígenas e contratados pela Secretaria de Estado da Educação do Estado de Santa Catarina. A maioria dos professores tem formação nas áreas em que atuam. Nessa escola, a língua materna é ensinada desde a Educação Infantil até Ensino Médio.

\subsubsection{Preocupação do povo Laklãnõ para recuperar seus costumes}

No ano de 1994, iniciou-se uma preocupação muito grande da comunidade de tentar revitalizar seus costumes, língua, nomes, cantigas e crenças que ao longo do tempo estavam 
sendo deixados de lado, por exemplo, a recuperação da bebida do povo Laklãnõ, que deixou de ser consumida após o contato. A bebida era servida na cerimônia ou festas ãgglan de furação dos lábios e nas demais outras festas.

A recuperação dos costumes está sendo realizada com apoio dos anciãos e dos professores responsáveis pelo ensino nas escolas existentes na comunidade Laklãnõ, onde o conhecimento das tradições vem sendo transmitido às crianças de toda a Terra Indígena Laklãnõ. A preocupação da comunidade com o resgate das histórias, revalorização dos costumes e da língua está presente. Assim, um dos caminhos seria ensinar, na escola, a falar, escrever e ler na própria língua Laklãnõ, para que esta não seja esquecida. A outra forma é procurar registrar a língua e as histórias em livros, para a geração futura aprender e saber das histórias dos seus antepassados.

Nesse contexto, a partir dos fatos e eventos históricos que descrevemos aqui, queremos registrar que os novos conhecimentos transmitidos, principalmente pela escola, permitem aos Laklãnõ exigir seus direitos enquanto sociedade indígena brasileira. Assim, o domínio da leitura, escrita e matemática permitirá aos mesmos reivindicar seus direitos e a não se calarem diante das injustiças da sociedade majoritária. 


\section{CAPÍTULO II - FONEMAS E ORTOGRAFIA DA LÍNGUA LAKLÃNÕ/XOKLENG}

\section{PRELIMINARES}

Neste capítulo faço uma breve exposição dos fonemas da língua Laklãnõ e de suas realizações fonéticas, incluindo observações sobre alguns processos fonológicos, sobre os padrões silábicos da língua e suas restrições fonotáticas. Trata-se de uma análise básica e necessária, fundada em procedimentos de análise como contraste e distribuição complementar (cf. PIKE 1943, 1947), observando princípios como os de sonoridade e de organização de elementos sonoros em classes específicas. Esta análise é portanto básica, simples mas efetiva, e sem pretensões teóricas. Nossa análise difere em vários aspectos das análises de Wiesemann (1968) e de Bulbitz (1996), quanto aos seus resultados.

\subsection{Os fonemas consonantais}

A língua Laklãnõ/Xokleng possui 13 fonemas consonantais e quinze fonemas vocálicos. Os fonemas consonantais podem ser subdivididos, de acordo com o critério sonoridade, em duas séries, uma surda $/ \mathrm{p}, \mathrm{t}, \mathrm{t} f, \mathrm{k}, \mathrm{k}^{\mathrm{w}}, \mathrm{\partial}, \mathrm{h} / \mathrm{e}$ outra sonora $/ \mathrm{m}, \mathrm{n}, \mathrm{d}, \mathrm{y}, \mathrm{g}^{\mathrm{w}}, \mathrm{v}, \mathrm{j}$, 1/ . A realização fonética dos fonemas consonantais distingue sete pontos de articulação bilabial, labio-dental, interdental, alveolar, alveo-palatal, velar, glotal - e seis modos de articulação - oclusivo, africado, fricativo, nasal, flepe, lateral e aproximante. Apresentamos, em seguida, um quadro com os fomemas consonantais do Laklãnõ e os seus respectivos fones e alofones. 
Quadro 1-dos Fonemas Consonantais

\begin{tabular}{|c|c|c|c|c|c|c|c|}
\hline & Bilabial & Interd. & Labiod. & Alveolar & Alveo-pal. & Velar & Glotal \\
\hline Oclus. & $/ \mathrm{p} /[\mathrm{p}]$ & & & $/ \mathrm{t} /[\mathrm{t}]$ & & $\begin{array}{l}/ \mathrm{k} /[\mathrm{k}] \\
/ \mathrm{k}^{\mathrm{w}} /\left[\mathrm{k}^{\mathrm{w}}\right]\end{array}$ & /?/ [?] \\
\hline Afric. & & & & & $/ \mathrm{t} \int /[\mathrm{t} f]$ & & \\
\hline Fricat. & $\begin{array}{l}\mathrm{v} /[\mathrm{v}] \\
\sim[\mathrm{w}][\mathrm{m}]\end{array}$ & $\begin{array}{l}/ \text { / [ð], } \\
{[\theta],[\mathrm{z}]}\end{array}$ & & & & & $/ \mathrm{h} /[\mathrm{h}]$ \\
\hline Nasal & $/ \mathrm{m} /[\mathrm{m}]\left[{ }^{\mathrm{m}} \mathrm{b}\right]$ & & & $/ \mathrm{n} /[\mathrm{n}]\left[{ }^{\mathrm{n}} \mathrm{d}\right]$ & $/ \tilde{\mathrm{n}} /[\tilde{\mathrm{n}}][\mathrm{d} 3]$ & $\begin{array}{l}/ \mathrm{y} /[\mathrm{y}]\left[{ }^{\mathrm{y}} \mathrm{g}\right] \\
/ \mathrm{y}^{\mathrm{w}} /\left[\mathrm{y}^{\mathrm{w}}\right] \\
{\left[{ }^{\mathrm{p}} \mathrm{g}^{\mathrm{w}}\right]}\end{array}$ & \\
\hline Aproix. & & & & $/ 1 /[1] \sim[1]$ & $/ \mathrm{j} /[\mathrm{j}]$ & & \\
\hline
\end{tabular}

Apresentamos, em seguida, os pares mínimos que ilustram os contrastes entre fonemas consonantais, seguidos de uma descrição de cada um deles:

Pares mínimos que ilustram o contraste entre fonemas que compartilham propriedades fonéticas.

$/ \mathbf{p} / \mathbf{v s} . / \mathbf{m} /$

(1) $/ \mathrm{pa} / \mathrm{pa}]$ 'embrulhar algo'

(2) $/ \mathrm{ma} /[\mathrm{mba}]$ 'pegar/

$/ \mathbf{t} / \mathbf{v s .} / \mathbf{t} \mathbf{J} /$

(3) $/$ tə/ [tə] 'mulher'

(4) $/ \mathrm{t} \int \partial /\left[\mathrm{t} \int \partial\right]$ 'preto'

/k/ vs. /kw/

(5) $/ \mathrm{kan} /[\mathrm{kan}]$ 'cavar'

(6) $/ \mathrm{k}^{\mathrm{w}} \mathrm{an} /\left[\mathrm{k}^{\mathrm{w}} \mathrm{an}\right]$ 'violar memória de alguém'

/k/ vs. / / /

(7) $/ \mathrm{du} \mathrm{Pu} / \mathrm{du} \mathrm{Pu}]$ 'nome próprio feminino'

(8) /duku/ [duku] 'comer tudo'

$/ \mathbf{y} / \mathbf{v s .} / \mathbf{y}^{\mathbf{w}} /$ 
(9) / / $\varepsilon /$ [ $\mathrm{\eta g} \varepsilon]$ 'pegal pl.'

(10) $/ \mathrm{jan}^{\mathrm{w}} \varepsilon /\left[\mathrm{jayg}^{\mathrm{w}} \varepsilon\right.$ ] 'abelha mandassaia'

/ð/ vs. /n/

(11) / /õ/ [ðõ] 'chorar'

(12) /nõ/ [nõ] 'deitar'

/h/ vs. /t $\mathbf{f} /$

(13) /huj/ [huj] 'assviar'

(14) /t fuj/ [tfuj] 'colocar algo líquido em recipiente'

/k/ vs. /t $\mathbf{~} /$

(15) /kan/ [kan] 'cavar'

(16) $/ \mathrm{t}$ fan/ [t fan] 'pisar'

$/ \mathbf{t} \mathbf{j} /$ vs. /j/

(17) $/ \mathrm{t}$ fan/ [t fan] 'pisar'

(18) /jan/ [jan] 'cantar'

/l/ vs. /n/

(19) /lõ/ [10̃] 'quente'

(20) /nõ/ [nõ] 'estar espalhado pl.'

$/ \mathbf{t} /$ vs. /n/

(21) $/ \mathrm{t} \tilde{\varepsilon} /[\mathrm{t} \tilde{\varepsilon}]$ 'ir'

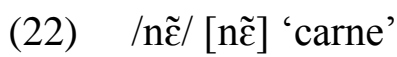

/n/ vs. /y/

(23) /tun/ [tun] 'rolar'

(24) /tup/ [tup] 'terminar'

/n/ vs. / /n/

(25) /nã/ [nã] 'forrar'

(26) /ñã/ [ñã] 'chupar mel' 
$/ \tilde{\mathbf{n}} / \mathbf{v s .} / \mathbf{t} \mathbf{j} /$

(27) /ñã/ [ñã] 'chupar mel'

(28) /t $\int \tilde{a} /[\mathrm{t} f \tilde{a}]$ 'esp. de gavião'

\subsubsection{Descrição dos fonemas consonantais}

Apresentamos em seguida uma descrição dos fonemas consonantais, com base nos traços que os distinguem uns dos outros.

Oclusivo bilabial surdo /p/

Exemplos:

$\begin{array}{llll}(29) & / \text { pupo/ } & \text { [pu'po] } & \text { 'sapo' } \\ (30) & / \text { pãn/ } & \text { [pãn] } & \text { 'pé' } \\ (31) & / \text { pli / } & \text { [pli] } & \text { 'samambaia' } \\ (32) & / \text { plã / } & \text { [plã] } & \text { 'cipó imbé' }\end{array}$

Oclusivo alveolar surdo /t/

Exemplos:

$\begin{array}{llll}\text { (33) } & / \text { tel/ } & \text { [tel] } & \text { 'morrer' } \\ \text { (34) } & / \text { tomã/ } & \text { [to'mã] } & \text { 'figado' } \\ (35) & / \text { tuton/ } & \text { [tu'ton] } & \text { 'borboleta' }\end{array}$

Oclusivo velar surdo /k/

Exemplos:

\begin{tabular}{|c|c|c|c|}
\hline (36) & /kot $\int \tilde{\varepsilon} \mathrm{n} /$ & [ko't tẽn] & 'rato' \\
\hline (37) & /kũm/ & [kũm] & 'carpir' \\
\hline & /koka/ & [ko'ka] & 'testa' \\
\hline & /klo/ & [klo] & 'brincar' \\
\hline
\end{tabular}

Oclusivo velar surdo labializado $/ \mathbf{k}^{\mathbf{w}} /$

Exemplos:

(40) /jak ${ }^{\mathrm{w} a}$ [ja' $\left.\mathrm{k}^{\mathrm{w}} \mathrm{a}\right] \quad$ 'nome do homem'

(41) $/ \mathrm{k}^{\mathrm{w}} \tilde{\varepsilon} \mathrm{n} \mathrm{k}^{\mathrm{w}} \tilde{\varepsilon} \mathrm{l} / \quad\left[\mathrm{k}^{\mathrm{w}} \tilde{\varepsilon} \mathrm{n}^{\mathrm{t}} \mathrm{k}^{\mathrm{w}} \tilde{\varepsilon} l^{\tilde{\varepsilon}}\right] \quad$ 'nome do pássaro' 
(42) $/ \mathrm{k}^{\mathrm{w}} \mathrm{an} / \quad\left[\mathrm{k}^{\mathrm{w}} \mathrm{an}\right] \quad$ 'violar memória de'

Oclusivo glotal surdo [?]

Exemplos:

$\begin{array}{llll}\text { (43) } & / \text { yuri } / & {[\text { ngu'Pi }]} & \text { 'jacu' } \\ \text { (44) } & / \text { nuPuy/ } & {\left[{ }^{n} \text { du'Puy }\right]} & \text { 'nome mulher' } \\ \text { (45) } & / \text { kaPuy/ } & \text { [ ka'Puy }] & \text { 'assustar' }\end{array}$

Oclusivo nasal bilabial /m/

Exemplos:

\begin{tabular}{|c|c|c|}
\hline /mẽy/ & 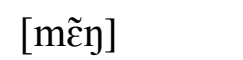 & 'onça' \\
\hline$/ \mathrm{me} /$ & {$\left[{ }^{\mathrm{m}} \mathrm{be}\right] \sim[\mathrm{be}]$} & 'mel' \\
\hline /kũm/ & [kũm] & 'carpir' \\
\hline$/ \mathrm{ma} /$ & {$\left[{ }^{\mathrm{m}} \mathrm{ba}\right] \sim[\mathrm{ba}]$} & 'jabuticaba' \\
\hline$/ \mathrm{men} /$ & {$[\mathrm{mb} \varepsilon \mathrm{n}] \sim[\mathrm{b} \varepsilon \mathrm{l}$} & ฤ] 'machado' \\
\hline
\end{tabular}

Oclusivo nasal alveolar $/ \mathbf{n} /$

Exemplos:

\begin{tabular}{|c|c|c|}
\hline (51) /ñ̃ $/$ & {$[\mathrm{n} \tilde{\varepsilon}]$} & 'carne' \\
\hline /põn/ & [põn] & 'cobra' \\
\hline /tun/ & [tun] & 'rolar' \\
\hline /no/ & {$[$ ndo $] \sim[$ ndo $]$} & 'flecha' \\
\hline /nõ/ & [nõ] & 'estar deitado' \\
\hline /nعyo/ & [ndeygo $] \sim[\mathrm{d} \varepsilon$ & عygo] 'pulga' \\
\hline
\end{tabular}

Oclusivo nasal alveopalatal / $\tilde{\mathbf{n}} /$

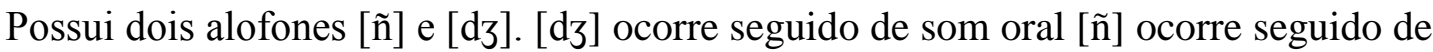
som nasal. Exemplos:

$\begin{array}{llll}\text { (57) } & / \tilde{\text { ñã }} & {[\tilde{\text { ñã }}} & \text { 'estar em pé' } \\ (58) & / \tilde{\text { ñu/ }} & {[\tilde{\text { ñu}}]} & \text { 'sabia coleira' } \\ (59) & / \tilde{\text { ñuñ }} & {[\text { dzuñ] }} & \text { pescoço' } \\ (60) & / \text { jin/ } & {[\text { dzin }]} & \text { 'costa' } \\ (61) & / \text { jun/ } & {[\text { dzun }]} & \text { 'minhoca' }\end{array}$


(62) $/ \mathrm{jin} / \quad$ [dzin] 'apagar'

Oclusivo nasal velar /y/

Exemplos:

$\begin{array}{llll}(63) & / \text { yel } / & {\left[{ }^{\text {g}} \text { gel }\right] \sim\left[{ }^{\text {g}} \text { gel }\right]} & \text { 'cheiro' } \\ (64) & / \text { ylẽy/ } & {[\text { yey }] \sim[\text { ylẽn }]} & \text { 'nadega, anus' } \\ (65) & / \text { ylã } / & {[\text { ylã }]} & \text { 'doce' } \\ (66) & / \text { yo/ } & {\left[{ }^{\text {ggo }}\right] \sim[\text { go }]} & \text { 'terra' } \\ (67) & / \text { yuy } / & {[\text { ygun }] \sim[\text { ggun }] \text { 'bugio' }}\end{array}$

Oclusivo velar nasal labializado $/ \mathbf{n}^{\mathrm{w} /}$

Exemplos:
(68) /nwin/ [ngwin] 'grito, choro de onça'
(69) $/ \mathrm{jay}^{\mathrm{w}} \varepsilon / \quad\left[\mathrm{ja}^{\prime \mathrm{p}} \mathrm{g}^{\mathrm{w}} \varepsilon\right] \quad$ 'abelha mandasaia'
(70) /vaywa [wa $\left.{ }^{\prime \mathrm{n}} \mathrm{g}^{\mathrm{w}} \mathrm{a}\right]$ 'tacuaraçu'
(71) /jonwĩn/ [jọ 'ĩn] 'dançar em círculos (sujeito plural)'

Africado alveopalatal surdo /t $\mathbf{f} /$

Exemplos:
(72) $/ \mathrm{t} \int \mathrm{i} /$
[ $\mathrm{t} f \mathrm{i}]$ 'velho'
(73) $/ \mathrm{t} \int \mathrm{a} /$
[t $\left.\int \mathrm{a}\right]$ 'pendurar (sujeito singular)'
(74) $/ \mathrm{t} \mathrm{\jmath} /$
[t $\left.\int \ni\right]$ 'preto'

Fricativo labiodental sonoro /v/

O fonema /v/ possui 3 alofones: [v] fricativa labiodental sonora, [m] aproximante labiodental sonora e [w], nasal labiodental. [m] e [w] estão em variação livre diante de fonema nasal, [v] ocorre nos demais ambientes. Exemplos:
(75) /van/
[van] [wan]
'taquara'
(76) /vaivuy/
[wajvuy] [majvuy] 'mexer-se'
(77) /vã/
[wã] $\sim[\mathrm{mã}]$
'aspecto continuativo-progressivo' 


\section{/ð/ Fricativo interdental sonoro}

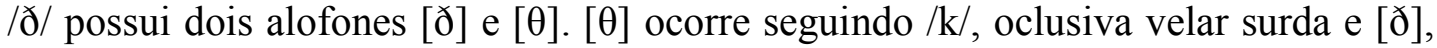
nos demais ambientes:

Exemplos:

\begin{tabular}{|c|c|c|c|}
\hline (78) & /ðaðan/ & [ða'ðan] & 'tatu' \\
\hline (79) & /ðо̃/ & [ðо̃] & 'chorar' \\
\hline (80) & /ðuðũ/ & [zu'ðũ] & 'arder' \\
\hline (81) & /kəkðعj/ & {$\left[\mathrm{k} \mathrm{k}^{\prime} \theta \varepsilon j \varepsilon\right]$} & 'morcego' \\
\hline (82) & /jakði/ & {$\left[\mathrm{jak}^{\prime} \theta \mathrm{i}\right]$} & 'antebraço' \\
\hline & /jakðẽn/ & [jak' $\theta$ ẽn] & 'espirar' \\
\hline
\end{tabular}

Fricativo glotal surdo /h/

Exemplos:

$\begin{array}{llll}\text { (84) } & \text { /hinvo/ } & \text { [hin'vo] } & \text { 'tatu do rabo mole' } \\ \text { (85) } & \text { /kuhũn/ } & {[\text { ku'hũn] }} & \text { 'vento' } \\ \text { (86) } & \text { /huj/ } & {[\text { huj] } \sim \text { [huji] }} & \text { 'assoviar ou assobiar' } \\ \text { (87) } & \text { /han/ } & {[\text { han }]} & \text { 'fazer' }\end{array}$

Aproximante lateral alveolar sonoro / /

Exemplos:

\begin{tabular}{|c|c|c|c|}
\hline (88) & $/ \mathrm{la} /$ & [la] & 'sol, dia' \\
\hline (89) & /laylu/ & [lay'lu] & ‘feijão' \\
\hline (90) & /lõ/ & [10̃] & 'quente' \\
\hline (91) & /mlã/ & [mlã] & 'cinza' \\
\hline (92) & $/ \mathrm{ylu} /$ & [ plũ] & 'tucano' \\
\hline (93) & /ləl/ & [lə'lə] & 'escrita' \\
\hline
\end{tabular}

Aproximante alveopalatal sonora /j/

O fonema /j/ possui um único fone [j].

Exemplos:
(94) $/ \mathrm{ja} /$
[ja]
'dente'
(95) /jã/
[jã]
'chupar mel' 

(96) $/ \mathrm{loj} /$
[loj]
'abrir'
(97) /vãjycj/
[wãj' $y \varepsilon j]$
'guerra'

\section{Alguns processos fonológicos}

As oclusivas nasais $/ \mathrm{m} /, / \mathrm{n} /, / \mathrm{y} /$ e $/ \mathrm{y}^{\mathrm{w}} /$ se tornam pós-oralizadas ou orais se seguidas de vogais orais, ocorrendo como nasais antes de silêncio.

$/ \mathrm{m} /, / \mathrm{n} /, / \mathrm{y} / \mathrm{e} / \mathrm{y}^{\mathrm{w}} /$ seguidas de vogais nasais:

Exemplos:

$\begin{array}{llll}(98) & / \mathrm{m} \tilde{\varepsilon} \mathrm{y} / & {[\mathrm{m} \tilde{\varepsilon} \mathrm{y}]} & \text { 'onça' } \\ (99) \quad / \mathrm{n} \tilde{\varepsilon} / & {[\mathrm{n} \tilde{\varepsilon}]} & \text { 'carne' } \\ (100) / \mathrm{ylãa} / & {[\mathrm{ylã}]} & \text { 'doce' } \\ (101) / \mathrm{kũm} / & {[\mathrm{kũm}]} & \text { 'carpir' }\end{array}$

$/ \mathrm{m} /, / \mathrm{n} /, / \mathrm{y} / \mathrm{e} / \mathrm{y}^{\mathrm{w}} /$ seguidas de vogais orais:

\begin{tabular}{|c|c|c|c|}
\hline (102) & $/ \mathrm{me} /$ & {$[\mathrm{mbe}] \sim[\mathrm{be}]$} & 'mel' \\
\hline (103) & $/ \mathrm{ma} /$ & {$[\mathrm{mba}] \sim[\mathrm{ba}]$} & 'jabuticaba' \\
\hline (104) & $/ \mathrm{m} \varepsilon \mathrm{y} /$ & {$[\mathrm{mbcy}] \sim[\mathrm{b} \varepsilon \mathrm{y}]$} & 'machado' \\
\hline (105) & /nعךo/ & {$\left[{ }^{\mathrm{n}} \mathrm{d} \varepsilon^{\mathrm{g}} \mathrm{g} \mathrm{g}\right] \sim\left[\mathrm{d} \varepsilon^{\mathrm{g}} \mathrm{g} \mathrm{g}\right]$} & 'pulga' \\
\hline (106) & /no/ & {$\left[{ }^{\mathrm{n}} \mathrm{do}\right] \sim\left[{ }^{\mathrm{n}} \mathrm{do}\right]$} & 'flecha' \\
\hline (107) & $/ \mathrm{nel} /$ & {$[$ ygel $] \sim[$ ygel $]$} & 'cheiro' \\
\hline (108) & /no/ & [ ggo] $\sim$ [ go] & 'terra' \\
\hline (109) & /jāwe/ & [ja'ngwe] & 'abelha mandasai a' \\
\hline (110) & /vaywa & {$\left[w^{\prime \prime} g^{w} a\right]$} & 'tacuaraçu' \\
\hline
\end{tabular}

O fonema $/ \mathrm{v} /$ muda para $[\mathrm{m}]$ ou para $[\mathrm{w}]$ seguido de fonema nasal na mesma palavra fonológica. Exemplos:
(111) /van/
[van]
'taquara'
(112) /vã/
[wã] [mã]
'aspecto continuativo-progressivo'
(113) /vajvuy/
[wajvuy] [majvuy] 'mexer-se'

O fonema /ð/ se torna menos sonoro quando precedido por /k/. Este processo assimilatório só ocorre em fronteira silábica. Exemplos: 

(114) /ðaðan/ [ða'ðan] 'tatu' $[\theta]$.

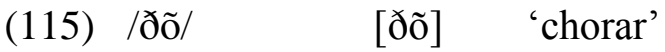
(116) /ðuðũ/ [zu'ðũ] 'arder'

Mas:
(117) $/ \mathrm{k} ə \mathrm{k} ð \varepsilon j / \quad\left[\mathrm{k}^{\prime} \mathrm{k}^{\prime} \theta \varepsilon j^{\varepsilon}\right]$ 'morcego'
(118) $/ \mathrm{jak} ð \mathrm{i} / \quad$ [jak' $\theta \mathrm{i}]$ 'antebraço'

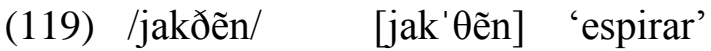

\section{Morfofonêmica}

$\mathrm{O}$ fonema $/ \mathrm{j} / \mathrm{e} / \tilde{\mathrm{n}} /$ mudam para $/ \mathrm{d} 3 /$ em fronteira de morfema, quando precedidos de fonema nasal. Exemplos:
(120) / $/ \tilde{j j j a / ~}$
[ع̃j'dza] 'meu dente'
(121) / ह̃jẽ̃̃a /
[थ̃j'ñẽ'ya] 'meu braço'

\section{Sandhi externo}

$/ \mathrm{k} /$ muda para $/ \mathrm{y} /$ quando precedido por $/ \mathrm{y} /$ :

ãy káki --> [ãy já'ki ]

1P pelo 'nosso pelo'

$\mathrm{Na}$ fala rápida os dois $/ \mathrm{y} / / \mathrm{y} /$ se fundem, $>/ \mathfrak{y} /$ :

ãy klẽg. [ãy'ylẽy]

1P nádegas 'nossas nádegas'

$/ \mathrm{t} /$ muda para $/ \mathrm{t} \mathrm{f} /$ quando precedido por $/ \mathrm{j} /$ :

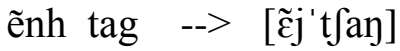

1 gordo 'minha gordura' 


\subsection{OS FONEMAS VOCÁLICOS}

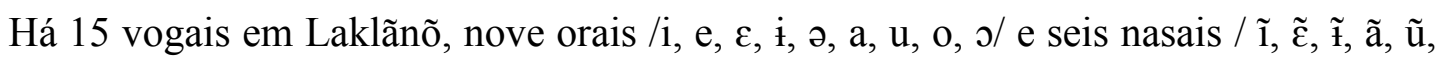
$\tilde{\jmath} /$, as quais contractam quando à altura - altas, médias, baixas -, quanto ao recuo e avanço da língua - anteriores, centrais e posteriores -, e quanto ao abaixamento e levantamento do véu palatino - nasais, orais. Apresentamos, em seguida, o quadro fonológico das vogais:

Quadro 2 - Fonemas Vocálicos

\begin{tabular}{|c|c|c|c|c|c|c|}
\hline & \multicolumn{2}{|c|}{ Anterior } & \multicolumn{2}{|c|}{ Central } & \multicolumn{2}{|c|}{ Poterior } \\
\hline & Oral & Nasal & Oral & Nasal & Oral & Nasal \\
\hline Alta & /i/ [i] ['] & $/ \tilde{1} /[\tilde{1}][\tilde{1}]$ & $/ \mathbf{i} /[\mathrm{i}]\left[{ }^{\mathrm{i}}\right]$ & $\tilde{\mid \mathbf{t}} / \tilde{\mathbf{t}} / \tilde{I} /$ & $/ \mathrm{u} /[\mathrm{u}]\left[^{\mathrm{u}}\right]$ & $/ \tilde{\mathrm{u}} /[\tilde{\mathrm{u}}]\left[{ }^{\mathrm{u}}\right]$ \\
\hline Média & $/ \mathrm{e} /[\mathrm{e}]\left[{ }^{\mathrm{e}}\right]$ & & $\left./ \mathrm{\partial} /[\mathrm{\partial}]{ }^{\mathrm{D}]}\right]$ & & $/ \mathrm{o} /[\mathrm{o}]\left[^{\circ}\right]$ & \\
\hline Baixa & $/ \varepsilon /[\varepsilon]\left[^{\varepsilon}\right]$ & $/ \tilde{\varepsilon} /[\tilde{\varepsilon}][\tilde{\varepsilon}]$ & $/ \mathrm{a} /[\mathrm{a}]\left[^{\mathrm{a}}\right]$ & $/ \tilde{a} /[\tilde{a}]\left[{ }^{\tilde{a}}\right]$ & $/ \mathrm{s} /[0]\left[^{0}\right]$ & $/ \tilde{\mathbf{\partial}} /[\tilde{\mathrm{o}}]\left[{ }^{\tilde{\partial}}\right]$ \\
\hline
\end{tabular}

Apresento, em seguida, os pares mínimos que ilustram os contrastes entre fonemas vocálicos, seguidos de uma descrição de cada um deles:

/i/ vs. /e/

$\begin{array}{lll}(122) / \text { tel/ } & {\left[\text { te'l }^{\mathrm{e}}\right]} & \text { 'morrer aos poucos' } \\ (123) / \text { till } & {\left[\mathrm{ti}^{\prime} \mathrm{l}^{\mathrm{i}}\right]} & \text { 'verruga' }\end{array}$

/e/ vs. / $/ \varepsilon$

$\begin{array}{lll}(124) / \text { tel/ } & {\left[\mathrm{te}^{\prime} \mathrm{l}^{\mathrm{e}}\right]} & \text { 'morrer aos poucos' } \\ \text { (125) } / \mathrm{k} \text { } & {[\mathrm{k \jmath} \text { 'ðej] }} & \text { 'flor' }\end{array}$

/e/ vs. /a/

(126) /ðəl/ [бə'lə] 'couro' 
(127) /ðel/ [ðe'le [ralado'

/a/ vs. /i/

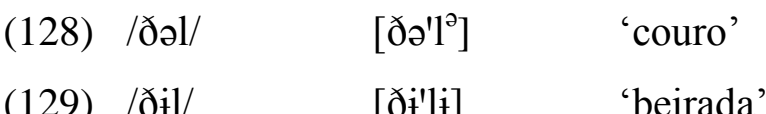

/i/ vs. /i/

(130) $/ \mathrm{ni} /$

[ $\left.{ }^{\mathrm{n}} \mathrm{di}\right] \quad$ 'rir'

(131) /nin/

[ndin] 'gota de algo'

/i/ vs. /u/

(132) /ni/

[ $\left.{ }^{\mathrm{n}} \mathrm{di}\right] \quad$ 'rir'

(133) /nuy/

[ $\left.{ }^{\mathrm{n}} \mathrm{dup}\right]$

'barriga'

/u/ vs. /o/

(134) /jul/

(135) /jol/

[ju'l' $\left.{ }^{\mathrm{u}}\right] \quad$ 'chegar'

[jo'lo] 'torto'

/o/ vs. /o/

(136) / jol/

$\left[\mathrm{jo}^{\prime} \mathrm{l}^{\mathrm{o}}\right]$

'torto'

(137) /jol/

[jo'lo]

'rasgado'

/o/ vs. /a/

(138) /jol/

$\left[\mathrm{jo}^{\prime} \mathrm{l}^{\mathrm{O}}\right]$

'torto'

(139) $/ \mathrm{j \jmath l} /$

$\left[j \partial^{\prime} 1^{2}\right]$

'torto'

/a/ vs. /a/

(140) /dal/

[da'la $\left.{ }^{\mathrm{a}}\right]$

'descer boiando'

(141) /dəl/

$\left[\mathrm{d} \partial^{\prime} \mathrm{l}^{\ominus}\right]$

'caroço'

(142) $/ \mathrm{t} \varepsilon \mathrm{n} /$

[ten]

'matar aos poucos'

(143) /tan/

[tan]

'contar'

/î/ vS. /ĩ/

(144) /nĩ/

[nĩ]

'estar' (sg.) 
(145) $/$ ñ̃t $\quad[$ ñ̃ $] \quad$ 'estar' (pl.)

(146) $/ \tilde{\mathrm{t}} /$ vs. $/ \tilde{\mathrm{u}} /$

(147) $/ \mathrm{n \tilde {t }} /$

[ñิ]

'estar' (pl.)

(148) /nũ/

[nũ]

'eu'

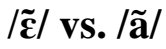

(149) /p $\tilde{\varepsilon} /$

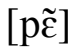

'lenha'

(150) /pãy/

[ãy]

'atirar'

/ã/ vs. / $/$

(151) /pãy/

[ãท]

'atirar'

(152) /põy/

[pว̃ท]

'remédio à base de carvão para cicratizar osso truncado'

$/ \tilde{\mathbf{i}} /$ VS. / $\tilde{\mathbf{a}} /$

$\begin{array}{llll}(153) / \text { ñ̃ } / & {[\text { ñ̃] }} & \text { 'estar' (pl.) } \\ (154) / \text { nã/ } & {[\text { nã] }} & \text { 'nós' }\end{array}$

\subsubsection{Descrição dos fonemas vocálicos}

Em seguida, descrevemos os fonemas vocálicos, tendo como referência os traços que os distinguem uns dos outros.

\section{Vogal anterior alta oral /i/}

\begin{tabular}{|c|c|c|c|}
\hline$(155)$ & /kanẽm/ & [ka'ñ̃m] & 'dentro' \\
\hline (156) & /kaði/ & [ka' $\mathrm{ki}]$ & 'comprido, deitado' \\
\hline (157) & / $\tilde{\varepsilon} \mathrm{jja} /$ & {$\left[\tilde{\varepsilon} j^{\prime} \mathrm{d} z \mathrm{a}\right]$} & 'meu dente' \\
\hline
\end{tabular}

\section{Vogal anterior media oral /e/}

$\begin{array}{lll}(158) / \text { tel/ } & {\left[\mathrm{te}^{\prime} \mathrm{l}^{\mathrm{e}}\right]} & \text { 'morrer aos poucos' } \\ (159) / \mathrm{bel} / & {\left[\mathrm{be}^{\prime} \mathrm{le}\right]} & \text { 'beirada' }\end{array}$


(160) $/ \mathrm{yel} / \quad$ [ $\left[{ }^{\mathrm{g} g e l}\right] \quad$ 'cheiro'

Vogal anterior baixa oral $/ \varepsilon /$

$\begin{array}{llll}(161) / \mathrm{t} \varepsilon \mathrm{j} / & {\left[\mathrm{t} \varepsilon^{\prime} \mathrm{j} \varepsilon\right]} & \text { 'comprido' } \\ (162) / \mathrm{\partial} \varepsilon \mathrm{j} / & {\left[\mathrm{\partial cj}^{\varepsilon}\right]} & \text { 'folha' } \\ (163) / \mathrm{d} \varepsilon \mathrm{t} \varepsilon \mathrm{j} / & {\left[\mathrm{d}^{\prime} \mathrm{t} \varepsilon \mathrm{j}^{\varepsilon}\right]} & \text { 'palmito' }\end{array}$

/i/ Vogal central alta oral

$\begin{array}{llll}(164) / \mathrm{vij} / & {\left[\mathrm{vit}^{\prime} \mathrm{j}\right]} & \text { 'espingarda' } \\ (165) / \mathrm{tidil} / & {\left[\mathrm{tì}^{\mathrm{i}} \mathrm{dili}\right]} & \text { 'macio' } \\ (166) / \mathrm{kil} / & {\left[\mathrm{kith}^{\prime} \mathrm{l}^{\mathrm{i}}\right]} & \text { 'gritar' }\end{array}$

Vogal central média oral /ə/

$\begin{array}{llll}(167) & / \text { ləl/ } & {\left[\mathrm{l}^{\prime} \mathrm{l}^{\curvearrowright}\right]} & \text { 'escrita' } \\ (168) & / \mathrm{j} ə \mathrm{l} / & {\left[\mathrm{jə} \mathrm{l}^{\curvearrowright}\right]} & \text { 'alça' } \\ (169) & / \text { /əl/ } & {\left[\partial^{\curvearrowright} \mathrm{l}^{\curvearrowright}\right]} & \text { 'couro' }\end{array}$

Vogal central baixa oral /a/

$\begin{array}{llll}(170) & / \mathrm{dal} / & {\left[\mathrm{da}^{\mathrm{a}} \mathrm{l}\right]} & \text { 'descer boiando' } \\ (171) & / \mathrm{gal} / & {\left[\mathrm{ga}^{\mathrm{a}} \mathrm{l}\right]} & \text { 'milho' } \\ (172) & \text { hal/ } & {\left[\mathrm{hall}^{\mathrm{a}}\right]} & \text { 'feito' }\end{array}$

Vogal posterior alta oral /u/

$\begin{array}{llll}(173) & / \text { ðul/ } & {\left[\mathrm{Ju}^{\prime} \mathrm{l}^{\mathrm{u}}\right]} & \text { 'azedo } \\ (174) & / \mathrm{tul} / & {[\mathrm{tu} / \mathrm{lu}]} & \text { 'rolado' } \\ (175) & / \mathrm{kul} / & {[\mathrm{ku} / \mathrm{lu}]} & \text { 'roupa' }\end{array}$


/jol/ $\quad\left[\mathrm{jo}^{\mathrm{O}} \mathrm{l}^{\mathrm{O}}\right] \quad$ 'torto'

/lov/ $\quad\left[\mathrm{lo}^{\prime} \mathrm{v}^{\mathrm{o}}\right] \quad$ 'furo'

/lol/ [lo' $\left.1^{\circ}\right]$ 'redondo'

Vogal posterior baixo oral /s/

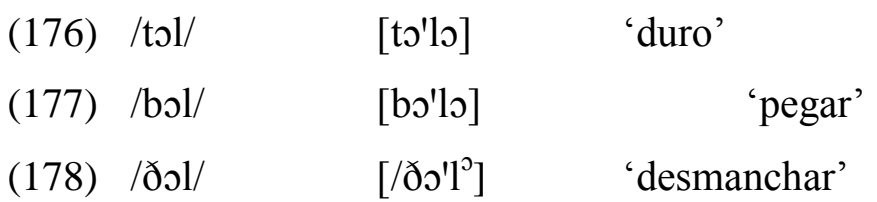

Vogal anterior alta nasal /ĩ/

$\begin{array}{lll}(179) / \text { nĩ/ } & {[\text { nĩ }]} & \text { 'estar' (sg.) } \\ (180) / \text { kotĩl/ } & {[\text { kotĩlĩ }]} & \text { 'lizo' }\end{array}$

Vogal anterior baixa nasal / $/ \tilde{\varepsilon} /$

$\begin{array}{llll}(181) / \mathrm{j} \tilde{\varepsilon} l / & {\left[\left.\mathrm{j} \tilde{\varepsilon}\right|^{\tilde{\varepsilon}}\right]} & \text { 'criança' } \\ (182) / \mathrm{j} \tilde{\varepsilon} \mathrm{l} / & {\left[\mathrm{\eta} \tilde{\varepsilon} l^{\tilde{\varepsilon}}\right]} & \text { 'cheiro' } \\ (183) / \mathrm{pl} \tilde{\varepsilon} \mathrm{l} / & {\left[\left.\mathrm{pl} \tilde{\varepsilon}\right|^{\tilde{\varepsilon}}\right]} & \text { 'avermelhado' }\end{array}$

Vogal central alta nasal / $/$ /

\begin{tabular}{|c|c|}
\hline (184) /ñ̃t & {$[\mathrm{n} \tilde{\mathrm{t}}]$} \\
\hline (185) / /niñ / & [ygก̃ $]$ \\
\hline (186) /pĩnpĩl/ & {$\left[\left.p \tilde{\operatorname{tn}}{ }^{\prime} p \tilde{\mathrm{q}}\right|^{\tilde{1}}\right]$} \\
\hline
\end{tabular}

/ã/ Vogal central baixa nasal

\begin{tabular}{|c|c|c|}
\hline (187) /plãl/ & [plã'lã $]$ & 'chorar \\
\hline ) /ðãl/ & [ðã' $\left.1^{\tilde{a}}\right]$ & 'pena da asa' \\
\hline (189) /vãl/ & [vã'l $\left.1^{a}\right]$ & 'ereto' \\
\hline
\end{tabular}




$\begin{array}{lll}\text { (190) } / \text { pũl/ } & \text { [pũ'lũ] } & \text { 'queimar' } \\ (191) / \text { bũj/ } & {[\text { bũ'jũ] }} & \text { 'desbarrancar' } \\ \text { (192) } / \text { /nũl/ } & {\left[\text { nũ'l }{ }^{\tilde{u}}\right]} & \text { 'dormir' }\end{array}$

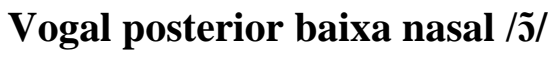

\begin{tabular}{|c|c|c|c|}
\hline (193) & /tõtõl/ & {$\left[\right.$ tõ tõ $\left.\left.\right|^{\tilde{D}}\right]$} & 'trovoada' \\
\hline (194) & /gõl/ & [gõ $\left.1^{\tilde{D}}\right]$ & 'derrubado' \\
\hline (195) & /tõlẽl/ & [tõ'lẽ $\left.\mathrm{l}^{\tilde{\mathrm{e}}}\right]$ & 'cuidar' \\
\hline
\end{tabular}

\subsection{PADRÕES SILÁBICOS}

A sílaba canônica em Laklãnõ é $\left(\left(C_{1}\right)\left(C_{2}\right) \mathrm{V}(C)\right)$.

Exemplos das possibilidádes silábicas são as seguintes:

\begin{tabular}{|c|c|c|c|}
\hline (196) & $\mathbf{V}$ & \multicolumn{2}{|c|}{ i 'não'; õ 'sim' } \\
\hline (197) & $\mathbf{C V}$ & $\mathrm{p} \tilde{\varepsilon}$ & 'lenha' \\
\hline (198) & $\mathrm{VC}$ & ẽn & 'casa', $\tilde{\varepsilon} \mathrm{j}$ 'eu' \\
\hline (199) & CVC & jin & 'costas' \\
\hline (200) & $\mathrm{CCV}$ & pli & 'samambaia' \\
\hline (201) & CCVC & klan & 'plantar' \\
\hline
\end{tabular}

\subsection{RESTRIÇÕES FONOTÁTICAS}

Grupos consonantais só são possíveis se $\mathrm{C}_{1}$ for $\mathrm{p}, \mathrm{k}, \mathrm{m}, \mathrm{y}$ e $\mathrm{C}_{2} \mathrm{l}$ :

$\mathrm{pl}$

(204)

$\mathrm{kl}$

(205)

$\mathrm{ml}$

j1 
Há uma proibição de encontros de consoantes homorgânicas, seja na mesma sílaba ou em fronteira silábica. Isso explica porque não há $t l$ nem $n l$ em Laklãnõ, entre outros encontros consonantais homorgânicos.

As consoantes que podem ocorrer em posição de margem direita de sílabas mediais são $k, m, n, y, j, 1$. Em sílaba final, apenas ocorrem m, n, y, j, l. Todas sonoras em todas as suas realizações.

Apresentamos em seguida as correspondências fonemas/grafemas, tendo em vista que os dados do Laklãnõ foram transcritos na escrita vigente, de forma que todos os Laklãnõ que dominam a leitura em sua língua nativa ler a descrição aqui apresentada.

QUADROS DEMONSTRATIVO DAS CORRESPONDENCIAS DOS FONEMAS X GRAFEMAS USADOS NA ESCRITA DOS DADOS LAKLÃNÕ NA PRESENTE TESE. CONSOANTES:

Quadro 3 - Correspondências dos fonemas x grafemas - consoantes

\begin{tabular}{|c|c|c|}
\hline & FONEMAS & LETRAS \\
\hline \multirow[t]{6}{*}{ Oclusivas e africadas } & $\mathrm{p}$ & $\mathrm{p}$ \\
\hline & $\mathrm{t}$ & $\mathrm{t}$ \\
\hline & $\mathrm{k}$ & $\mathrm{k}$ \\
\hline & $?$ & 1 \\
\hline & $\mathrm{k}^{\mathrm{w}}$ & $\mathrm{kw}$ \\
\hline & $\mathrm{t} \int$ & tx \\
\hline \multirow{3}{*}{ Fricativas } & $\mathrm{v}$ & $\mathrm{v}$ \\
\hline & д & $\mathrm{z}$ \\
\hline & $\mathrm{h}$ & $\mathrm{h}$ \\
\hline \multirow{3}{*}{ Nasais } & $\mathrm{m}$ & $\mathrm{m}$ \\
\hline & $\mathrm{n}$ & $\mathrm{n}$ \\
\hline & $\mathrm{n}$ & $\mathrm{d}$ \\
\hline \multirow[t]{2}{*}{ Aproximantes } & 1 & 1 \\
\hline & $\mathrm{j}$ & $\mathrm{j}$ \\
\hline
\end{tabular}


VOGAIS:

Quadro 4 - Correspondências dos fonemas x grafemas - vogais

\begin{tabular}{|c|c|c|}
\hline & Fonemas & Letras \\
\hline \multirow[t]{6}{*}{ Altas } & $\mathrm{i}$ & $\mathrm{i}$ \\
\hline & $\tilde{1}$ & $\tilde{1}$ \\
\hline & $\dot{\mathrm{i}}$ & $\mathrm{y}$ \\
\hline & $\tilde{\mathrm{t}}$ & $\tilde{y}$ \\
\hline & $\mathrm{u}$ & $\mathrm{u}$ \\
\hline & $\tilde{\mathrm{u}}$ & $\tilde{\mathrm{u}}$ \\
\hline \multirow{3}{*}{ Média } & $\mathrm{e}$ & $\mathrm{e}$ \\
\hline & ə & á \\
\hline & o & o \\
\hline \multirow{6}{*}{ Baixas } & $\varepsilon$ & é \\
\hline & $\tilde{\varepsilon}$ & $\tilde{\mathrm{e}}$ \\
\hline & $\mathrm{a}$ & $\mathrm{a}$ \\
\hline & $\tilde{a}$ & $\tilde{a}$ \\
\hline & 0 & ó \\
\hline & $\tilde{\mathbf{\jmath}}$ & $\tilde{\mathrm{o}}$ \\
\hline
\end{tabular}

\subsection{ALGUMAS OBSERVAÇÕES FINAIS}

O estudo aqui apresentado, embora breve, apresenta os fonemas do Laklãnõ atual. Uma análise mais detalhada da fonética da língua, inclusive em uma perspectiva acústica é necessária para que se tenham detalhes importantes da natureza dos sons que carcaterizam o Laklãnõ. É também necessário que se proceda a um inventário das variações fonéticas, considerando variáveis diastráticas e diagenéricas. A este respeito estamos desenvolendo um estudo que comporá o Atlas Sonoro das Línguas Indígenas do Brasil, coordenado pelo LALLI/UnB e pela UFPA. 


\section{CAPÍTULO III - CLASSES DE PALAVRAS}

\section{PRELIMINARES}

Neste capítulo descrevemos as classes de palavras da língua Laklãnõ. Coseriu (1972) sugere que um estudo dessa natureza pode, e às vezes deve partir de formas que, na realidade, constituem seu único objeto. Porém, enquanto ignore o significado, só pode comprovar esquemas e chamá-los, eventualmente, com nomes convencionais, por ex. , A, B, C, D....

Na definição das classes de palavras postuladas para a língua Laklãnõ damos atenção máxima ao significado de cada um dos seus elementos. As categorias verbais de substantivo, adjetivo, verbo e advérbio foram referências fundamentais nesse estudo, mas como observa Coseriu (1972 ) as categorias podem justificar a constituição de classes, porém não podem definir-se como classes.

Segundo Coseriu:

Podemos constituir a classe dos objetos triangulares, mas isso não significa definir a "triangularidade", que não é a classe desses objetos, senão, ao contrário, a razão pela qual se constitui a classe, posto que corresponde a um modo de ser dos objetos que nela se incluem. Analogamente, as categorias verbais correspondem a modos de ser das palavras. Porém a analogia vale somente até certo ponto, porque as palavras não são "coisas" senão "acontecimentos" e o caráter categorial delas não é algo fisicamente observável, senão uma função significativa e, como tal, somente pensável. Além disso, o caráter categorial não é um traço constante na mesma forma. Por tudo isso, as "classes" de palavras são necessariamente classes de palavras abstratas e sua extensão e índole dependem do sentido em que se haja realizado a abstração. Ao contrário, as categorias são partes oracionais, ou seja, que se dão concretamente como modos de ser das palavras no discurso, como funções semânticas.

Tivemos, assim, o cuidado de observar os significados das formas lexicais e de identificar as suas respectivas formas categoriais, assim como o modo de ser das palavras Laklãnõ no discurso.

\subsection{SUBSTANTIVOS, OU MAIS BEM PROPRIAMENTE NOMES}

Neste capítulo, tratamos das palavras que constituem a classe dos nomes em Laklãnõ. Pertencem a esta classe todas as palavras cujos referentes são [+ humano] ou [ humano], [+ feminino] ou [ - feminino] e, dos [- humanos], os que são [+ animado] ou [ - 
animado]. Nomes podem ser possuídos, sem mediador de posse, ou por meio de mediador de posse. Podem ainda ser atenuados e intensificados, e os seus respectivos referentes têm existência atual, retrospectiva ou prospectiva. Palavras que apresentam esses traços são, assim, as que descrevemos como pertencentes à classe dos nomes.

\subsubsection{Subclasses de nomes}

Iniciamos a descrição das características dos nomes pondo em relevo os traços relativo e absoluto. A classe dos nomes apresenta, dessa forma, três subclasses de elementos, fundadas na possibilidade de serem ou não núcleo em uma relação de determinação nominal, que, em Laklãnõ é uma relação de posse. Consequentemente, há que se distinguir um nome cujo referente é [+relativo, -absoluto], de um nome [-relativo, - absoluto], de um nome [+ absoluto, -relativo].

Um nome [+relativo, -absoluto] pode ser possuído diretamente, mas um nome [relativo e - absoluto] só pode ser possuído por meio de um mediador de posse; já um nome [+ absoluto e-relativo] nunca pode ser possuído.

\section{Nome [+ relativo, -absoluto]}

A classe dos nomes [+ relativo, - absoluto] possui duas subclasses, uma divisão parcialmente fundada em critério semântico. Os referentes das duas subclasses são partes de um todo, mas enquanto a subclasse 1a é constituída de elementos que se combinam com pronomes, a subclasse $1 \mathrm{~b}$ se combina apenas com um outro nome e, muitos deles, só se combinam com nomes cujos referentes são, por sua vez, parte do referente de outro nome, como veremos na seção 3.2.4.

\subsection{OS SIGNIFICADOS LEXICAIS DOS NOMES RELATIVOS E ABSOLUTOS}

Os nomes relativos são nomes de partes de um todo, como partes do corpo humano, partes do corpo de animais, partes de plantas, nomes que expressam relações de parentesco e nomes de sensações.

\subsubsection{Nomes relativos da subclasse 1}


Nomes relativos da subclasse 1 se combinam com um determinante. Esta subclasse apresenta uma cisão, fundada na distribuição de seus elementos. Há nomes que se combinam com um determinante, seja este nome ou pronome, mas há nomes que só combinam com outros nomes, restringindo a sua combinação com pronomes em processos metafóricos ou metonímicos. Para diferenciá-los em classes distintas, chamamos a primeira de subclasse 1a e a segunda de subclasse $1 b$.

Os pronomes que se combinam com nomes da subclasse 1a são os que marcam também o objeto de verbos transitivos e o sujeito de predicados que têm por núcleo um nome ou um adjetivo. Marcam também predicados verbais no aspecto progressivo, caso em que se combinam com a expressão $\tilde{e} t \int \tilde{o}$, na primeira pessoa, e tõ nas demais pessoas, como veremos no capítulo sobre alinhamento. Aqui nos restringimos a exemplificar a combinação desses pronomes com nomes relativos da subclasse 1a.

Quadro 5 - Pronomes do conjunto 2

\begin{tabular}{|l|l|l|l|l|}
\hline \multicolumn{3}{|c|}{ Singular } & \multicolumn{2}{c|}{ Plural } \\
\hline $1^{\mathrm{a}} \mathrm{P}$. & ẽnh & eu & ãg & nós \\
\hline $2 \mathrm{P}$. & $\mathrm{a}$ & tu & mẽ a & vocês \\
\hline $\begin{array}{r}3^{\text {a }} \mathrm{P} . \text { Masc. } \\
\text { Fem. }\end{array}$ & $\begin{array}{l}\mathrm{ti} \\
\text { zi }\end{array}$ & $\begin{array}{l}\text { ele } \\
\text { ela }\end{array}$ & óg & $\begin{array}{l}\text { eles } \\
\text { elas }\end{array}$ \\
\hline
\end{tabular}

Apresentamos, em seguida, os exemplos de nomes da classe 1a combinados com pronomes do conjunto 2 na função de possessivos. Os exemplos ilustram paradigmas de nomes de referentes de campos semânticos distintos combinados com esses pronomes:

Partes do corpo humano

'olho'

\begin{tabular}{|c|c|}
\hline $\begin{array}{l}\text { (206) ẽnh kónã } \\
1 \text { olho } \\
\text { 'meu olho' }\end{array}$ & $\begin{array}{l}\text { (207) ãg } \quad \text { gónã } \\
\text { 1P } \text { olho } \\
\text { 'nosso olho' }\end{array}$ \\
\hline $\begin{array}{l}\text { (208) a } \quad \text { kónã } \\
\text { 2P olho } \\
\text { 'seu olho/ olho de você' }\end{array}$ & $\begin{array}{l}\text { (209) mẽ a kónã } \\
\text { 2P olho } \\
\text { 'seus olhos/ olhos de vocês' }\end{array}$ \\
\hline $\begin{array}{l}\text { (210) ti kónã } \\
3 \mathrm{M} \text { olho } \\
\text { 'olho dele' }\end{array}$ & $\begin{array}{l}\text { (211) zi kónã } \\
\text { 3F olho } \\
\text { 'olho dela' }\end{array}$ \\
\hline
\end{tabular}




$$
\begin{gathered}
\text { (212) óg kónã } \\
\text { 3P olho } \\
\text { 'olho deles' }
\end{gathered}
$$

\begin{tabular}{|c|c|}
\hline $\begin{array}{c}\text { (213) ẽnh } \text { jẽgga } \\
1 \quad \text { mão } \\
\text { 'minha mão' }\end{array}$ & $\begin{array}{l}\text { (214) ãg nẽgga } \\
\text { 1P mão } \\
\text { 'nossa mão' }\end{array}$ \\
\hline $\begin{array}{c}\text { (215) a nẽgga } \\
2 \text { mão } \\
\text { 'sua mão }\end{array}$ & $\begin{array}{l}\text { (216) mẽ a nẽgga } \\
\text { 2P mão } \\
\text { 'mão de vocês' }\end{array}$ \\
\hline $\begin{array}{l}\text { (217) ti nẽgg a } \\
3 \mathrm{M} \text { mão } \\
\text { 'mão dele' } \\
\text { (218) óg nẽgga } \\
\text { 3P mão } \\
\text { 'mão deles' }\end{array}$ & $\begin{array}{c}\text { (219) zi } \text { nẽgg a } \\
3 \mathrm{~F} \text { mão } \\
\text { 'mão dela' }\end{array}$ \\
\hline
\end{tabular}

'mão'

\begin{tabular}{|c|c|}
\hline $\begin{array}{c}\text { (220) ẽnh pãn } \\
1 \text { pé } \\
\text { 'meu pé' }\end{array}$ & $\begin{array}{c}\text { (221) ãg pãn } \\
\text { 1P pé } \\
\text { 'nosso pé' }\end{array}$ \\
\hline $\begin{array}{c}\text { (222) a pãn } \\
2 \text { pé } \\
\text { 'seu pé' }\end{array}$ & $\begin{array}{l}\text { (223) mẽ a pãn } \\
\text { 2P pé } \\
\text { 'pé de vocês' }\end{array}$ \\
\hline $\begin{array}{l}\text { (224) ti pãn } \\
3 \mathrm{M} \text { pé } \\
\text { 'pé dele' }\end{array}$ & $\begin{array}{c}\text { (225) zi pãn. } \\
\text { 3F pé } \\
\text { 'pé dela' }\end{array}$ \\
\hline $\begin{array}{l}\text { (226) óg pãn } \\
\text { 3P pé } \\
\text { 'pé deles' }\end{array}$ & \\
\hline
\end{tabular}

\section{'pé'}


'boca'

\begin{tabular}{|c|c|}
\hline $\begin{array}{c}\text { (227) ẽnh jãnky } \\
1 \quad \text { boca } \\
\text { 'minha boca' }\end{array}$ & $\begin{array}{c}\text { (228) ãg jãnky } \\
\text { 'nossa boca' }\end{array}$ \\
\hline $\begin{array}{c}(229) \text { a jãnky } \quad \text { mẽ a jãnky } \\
\text { 'sua boca' }\end{array}$ & 'boca de vocês' \\
3M boca & (232) zi jãnky \\
'boca dele' & 'boca dela' \\
\hline (233) óg jãnky & \\
3P boca & \\
'boca deles' & \\
\hline
\end{tabular}

'nariz'

\begin{tabular}{|c|c|}
\hline $\begin{array}{l}\text { (234) ẽnh nẽjã. } \\
1 \text { nariz } \\
\text { 'meu nariz' }\end{array}$ & $\begin{array}{l}\text { (235) ãg nẽjã } \\
\text { 1P nariz } \\
\text { 'nosso nariz' }\end{array}$ \\
\hline $\begin{array}{c}\text { (236) a } \quad \text { nẽjã } \\
2 \text { nariz } \\
\text { 'seu nariz' }\end{array}$ & $\begin{array}{l}\text { (237) mẽ a nẽjã } \\
\text { 2P nariz } \\
\text { 'nariz de vocês' }\end{array}$ \\
\hline $\begin{array}{c}\text { (238) ti } \quad \text { nẽjã } \\
3 \mathrm{M} \text { nariz } \\
\text { 'nariz dele' }\end{array}$ & $\begin{array}{l}\text { (239) zi } \quad \text { nẽjã } \\
\text { 3F } \quad \text { nariz } \\
\text { 'nariz } \\
\text { dela' }\end{array}$ \\
\hline $\begin{array}{l}\text { (240) óg nẽjã } \\
\text { 3P nariz } \\
\text { 'nariz deles' }\end{array}$ & \\
\hline
\end{tabular}

'pelo'

\begin{tabular}{|c|c|}
\hline $\begin{array}{l}\text { (241) ẽnh kágki } \\
1 \text { pelo } \\
\text { 'meu pelo' }\end{array}$ & $\begin{array}{c}\text { (242) ãg gágki } \\
\text { 1P pelo } \\
\text { 'nosso pelo' }\end{array}$ \\
\hline $\begin{array}{cl}\text { (243) a } & \text { kágki } \\
2 & \text { pelo }\end{array}$ & $\begin{array}{l}\text { (244) mẽ a kágki } \\
\text { 2P pelo }\end{array}$ \\
\hline
\end{tabular}




\begin{tabular}{|c|c|}
\hline 'teu pelo' & 'pelo de vocês' \\
\hline $\begin{array}{c}\text { (245) ti } \text { kágki } \\
3 \mathrm{M} \text { pelo } \\
\text { 'pelo dele' }\end{array}$ & $\begin{array}{l}\text { (246) 41. zi kágki } \\
\text { 3F pelo } \\
\text { 'pelo dela' }\end{array}$ \\
\hline $\begin{array}{l}\text { (247) óg kágki } \\
\text { 3P pelo } \\
\text { 'pelo deles' }\end{array}$ & \\
\hline
\end{tabular}

'sola do pé'

\begin{tabular}{|c|c|}
\hline $\begin{array}{l}\text { (248) ẽnh pãn ka } \\
1 \text { pé sola } \\
\text { 'sola do meu pé' }\end{array}$ & $\begin{array}{l}\text { (249) ãg pãn ka } \\
\text { 1P pé sola } \\
\text { 'sola do nosso pé' }\end{array}$ \\
\hline $\begin{array}{l}\text { (250) a pãn ka } \\
2 \text { pé sola } \\
\text { 'sola do teu pé' }\end{array}$ & $\begin{array}{l}\text { (251) mẽ a pãn ka } \\
2 \mathrm{P} \text { pé sola } \\
\text { 'sola do pé deles' }\end{array}$ \\
\hline $\begin{array}{l}\text { (252) ti pãn ka } \\
3 \mathrm{M} \text { pé sola } \\
\text { 'sola do pé dele' }\end{array}$ & $\begin{array}{l}\text { (253) zi pãn ka } \\
\text { 3F pé sola } \\
\text { 'sola do pé dela' }\end{array}$ \\
\hline $\begin{array}{l}\text { (254) óg pãn ka } \\
\text { 3P pé sola } \\
\text { 'sola do pé deles' }\end{array}$ & \\
\hline
\end{tabular}

'nádegas'

\begin{tabular}{|c|c|}
\hline $\begin{array}{c}\text { (255) ẽnh glẽg } \\
1 \quad \text { nádega } \\
\text { 'minha nádega' }\end{array}$ & $\begin{array}{c}\text { (256) ãg glẽg. } \\
1 \mathrm{P} \text { nádegas } \\
\text { 'nossas nádegas' }\end{array}$ \\
\hline $\begin{array}{c}\text { (257) a glẽg } \quad \text { nádega } \\
\text { 'sua nádega' }\end{array}$ & mẽ a glẽg nádegas \\
& 'nádegas de vocês' \\
\hline
\end{tabular}




\begin{tabular}{|c|c|}
\hline $\begin{array}{c}\text { (259) ti glẽg } \\
\text { 3M nádega }\end{array}$ & 3F nádega \\
‘nádega dele' & 'nádega dela' \\
\hline (261) óg glẽg & \\
3P nádega & \\
'nádega deles' & \\
\hline
\end{tabular}

'estômago'

\begin{tabular}{|c|c|}
\hline $\begin{array}{l}\text { (262) ẽnh djug bág } \\
1 \text { estômago ADV } \\
\text { 'meu estômago' }\end{array}$ & $\begin{array}{c}\text { (263) ãg dug bág } \\
\text { 1P estômago ADV } \\
\text { 'nosso estômago' }\end{array}$ \\
\hline 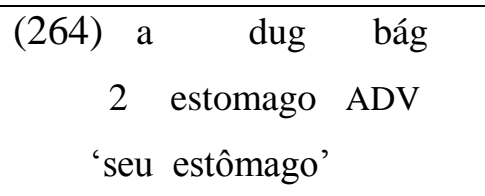 & $\begin{array}{l}\text { (265) mẽ a dug bág } \\
\text { 2P estômago ADV } \\
\text { 'estômago de vocês' }\end{array}$ \\
\hline $\begin{array}{cccc}\text { (266) } & \text { ti } & \text { dug } & \text { bág } \\
3 \mathrm{M} & \text { estômago } & \text { ADV } \\
\text { 'estômago dele' } & \end{array}$ & $\begin{array}{c}\text { (267) zi dug bág } \\
\text { 3F estômago ADV } \\
\text { 'estômago dela' }\end{array}$ \\
\hline $\begin{array}{l}\text { (268) óg dug bág } \\
\text { 3P estomago ADVB } \\
\text { 'estômago deles' }\end{array}$ & \\
\hline
\end{tabular}

'vagina'

\begin{tabular}{|c|c|}
\hline $\begin{array}{l}\text { (269) ẽnh } \mathrm{zu} \\
1 \quad \text { vagina } \\
\text { 'minha vagina' }\end{array}$ & 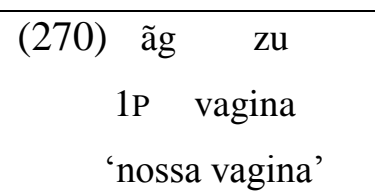 \\
\hline $\begin{array}{cr}\text { (271) a } & \mathrm{zu} \\
2 & \text { vagina } \\
& \text { 'sua vagina' }\end{array}$ & $\begin{array}{l}\text { (272) mẽ a } \mathrm{zu} \\
2 \mathrm{P} \quad \text { vagina } \\
\text { 'vagina de vocês' }\end{array}$ \\
\hline
\end{tabular}

'sangue'

\begin{tabular}{|c|c|}
\hline $\begin{array}{c}\text { (273) ẽnh kávénh } \\
1 \quad \text { sangue } \\
\text { 'meu sangue' }\end{array}$ & $\begin{array}{c}\text { (274) ãg gávénh } \\
1 \mathrm{P} \quad \text { sangue }\end{array}$ \\
\hline$(275)$ a kasso sangue' \\
\hline
\end{tabular}




\begin{tabular}{|c|c|}
\hline $\begin{array}{c}2 \\
\text { sangue }\end{array}$ & \multicolumn{2}{|c|}{$\begin{array}{c}\text { sangue } \\
\text { 'sangue de vocês' }\end{array}$} \\
\hline (277) ti kangue' $\quad$ kávénh & $(278)$ zi kávénh \\
$3 \mathrm{M}$ sangue & $3 \mathrm{~F} \quad$ sangue \\
'sangue dele' & 'sangue dela' \\
\hline (279) óg kávénh $\quad$ sangue & \\
'sangue deles' & \\
\hline
\end{tabular}

'gordura'

\begin{tabular}{|c|c|}
\hline $\begin{array}{l}\text { (280) ẽnh txag. } \\
1 \text { gordura } \\
\text { 'minha gordura' }\end{array}$ & 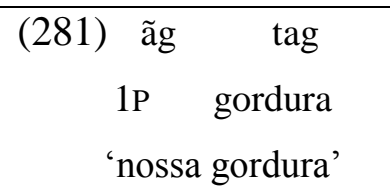 \\
\hline $\begin{array}{l}\text { (282) } 81 . \text { a tag } \\
2 \text { gordura } \\
\text { 'sua gordura' }\end{array}$ & $\begin{array}{l}\text { (283) mẽ a tag } \\
\text { 2P gordura } \\
\text { 'gordura de vocês' }\end{array}$ \\
\hline $\begin{array}{l}\text { (284) } \text { ti } \quad \text { tag } \\
3 \mathrm{M} \text { gordura } \\
\text { 'gordura dele' }\end{array}$ & $\begin{array}{ccc}(285) & \mathrm{zi} & \text { tag } \\
\text { 3F } & \text { gordura } \\
\text { 'gordura dela' }\end{array}$ \\
\hline $\begin{array}{l}\text { (286) óg tag. } \\
\text { 3P gordura } \\
\text { 'gordura deles' }\end{array}$ & \\
\hline
\end{tabular}

klẽ 'cabeça'

\begin{tabular}{|c|c|}
\hline $\begin{array}{l}\text { (287) ẽnh klẽ } \\
1 \quad \text { cabeça } \\
\text { 'minha cabeça' }\end{array}$ & $\begin{array}{l}\text { (288) ãg glẽ } \\
\text { 1P cabeça } \\
\text { 'nossa cabeça' }\end{array}$ \\
\hline $\begin{array}{c}\text { (289) a } \quad \text { klẽ } \\
2 \text { cabeça } \\
\text { 'sua cabeça' }\end{array}$ & $\begin{array}{l}\text { (290) mẽ a klẽ } \\
\text { 2P cabeça } \\
\text { 'cabeça de vocês' }\end{array}$ \\
\hline $\begin{array}{l}\text { (291) ti } \quad \text { klẽ } \\
3 \mathrm{M} \quad \text { cabeça } \\
\text { 'cabeça dele' }\end{array}$ & $\begin{array}{c}\text { (292) zi } \quad \text { klẽ } \\
\text { 3F } \quad \text { cabeça } \\
\text { 'cabeça dela' }\end{array}$ \\
\hline $\begin{array}{l}\text { (293) óg klẽ } \\
\text { 3P cabeça } \\
\text { 'cabeça deles' }\end{array}$ & \\
\hline
\end{tabular}


'bico/dente'

\begin{tabular}{|c|c|}
\hline $\begin{array}{c}\text { (294) ẽnh ja } \\
1 \quad \text { dente } \\
\text { 'meu dente' }\end{array}$ & $\begin{array}{l}\text { (295) ãg dja } \\
\text { 1P dente } \\
\text { 'nosso dente' }\end{array}$ \\
\hline $\begin{array}{c}\text { (296) } \text { a } \quad \text { ja } \\
2 \quad \text { dente } \\
\text { 'seu dente' }\end{array}$ & $\begin{array}{l}\text { (297) mẽ a ja } \\
\text { 2P dente } \\
\text { 'dente de vocês' }\end{array}$ \\
\hline $\begin{array}{c}\text { (298) ti ja } \\
3 \mathrm{M} \text { dente } \\
\text { 'dente dele' }\end{array}$ & $\begin{array}{c}\text { (299) zi } r \quad \text { ja } \\
\text { 3F dente } \\
\text { 'dente dela' }\end{array}$ \\
\hline $\begin{array}{rr}\text { (300) óg } & \text { dja } \\
3 \mathrm{P} & \text { dente } \\
\text { 'dente deles' }\end{array}$ & \\
\hline
\end{tabular}

'pena'

\begin{tabular}{|c|c|}
\hline $\begin{array}{c}\text { (301) ẽnh kágki } \\
1 \text { pelo } \\
\text { 'meu pelo' }\end{array}$ & $\begin{array}{c}\text { (302) ãg gágki } \\
\text { 1P pelo } \\
\text { 'nosso pelo' }\end{array}$ \\
\hline $\begin{array}{c}\text { (303) a kágki } \\
2 \text { pelo } \\
\text { 'seu pelo' }\end{array}$ & $\begin{array}{l}\text { (304) mẽ a kágki } \\
\text { 2P pelo } \\
\text { 'pelo de vocês' }\end{array}$ \\
\hline $\begin{array}{c}\text { (305) ti kágki } \\
3 \mathrm{M} \text { pelo } \\
\text { 'pelo dele' }\end{array}$ & $\begin{array}{c}\text { (306) zi kágki } \\
\text { 3F pelo } \\
\text { 'pelo dela' }\end{array}$ \\
\hline $\begin{array}{c}\text { (307) óg kágki } \\
\text { 3P pelo } \\
\text { 'pelo deles' }\end{array}$ & \\
\hline
\end{tabular}


'fígado'

\begin{tabular}{|c|c|}
\hline $\begin{array}{l}\text { (308) ẽnh tomã } \\
1 \quad \text { fígado } \\
\text { 'meu fígado' }\end{array}$ & $\begin{array}{l}\text { (309) ãg tomã } \\
\text { 1P fígado } \\
\text { 'nosso fígado' }\end{array}$ \\
\hline 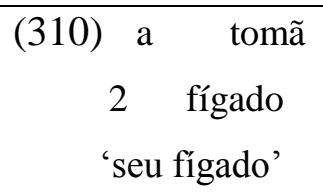 & $\begin{array}{l}\text { (311) mẽ a tomã } \\
\text { 2P fígado } \\
\text { 'fígado de vocês' }\end{array}$ \\
\hline $\begin{array}{r}\text { (312) ti tomã } \\
3 \mathrm{M} \text { fígado } \\
\text { 'fígado dele' }\end{array}$ & $\begin{array}{l}\text { (313) zi tomã } \\
\text { 3F fígado } \\
\text { 'fígado dela' }\end{array}$ \\
\hline $\begin{array}{l}\text { (314) óg tomã } \\
\text { 3P fígado } \\
\text { 'fígado deles' }\end{array}$ & \\
\hline
\end{tabular}

'coração'

\begin{tabular}{|c|c|}
\hline $\begin{array}{l}\text { (315) ẽnh } \text { ze } \\
1 \quad \text { coração } \\
\text { 'meu coração' }\end{array}$ & $\begin{array}{l}\text { (316) } \text { ãg } \quad \text { ze } \\
\text { 1P } \quad \text { coração } \\
\text { 'nosso coração' }\end{array}$ \\
\hline $\begin{array}{cc}\text { (317) } & \text { a } \\
2 & \text { ze } \\
2 & \text { coração } \\
\text { 'seu coração' }\end{array}$ & $\begin{array}{l}\text { (318) ẽ a } \quad \text { ze } \\
\text { 2P } \quad \text { coração } \\
\text { 'coração de você'’ }\end{array}$ \\
\hline $\begin{array}{l}\text { (319) ti } c \text { ze } \\
3 \mathrm{M} \text { coração } \\
\text { 'coração dele' }\end{array}$ & $\begin{array}{l}\text { (320) } \text { zi } \\
\text { 3F } \\
\text { zeração } \\
\text { 'coração dela' }\end{array}$ \\
\hline $\begin{array}{l}\text { (321) óg ze } \\
\text { 3P coração } \\
\text { 'coração deles' }\end{array}$ & \\
\hline
\end{tabular}


'pescoço'

\begin{tabular}{|c|c|}
\hline $\begin{array}{l}\text { (322) ẽnh djunh } \\
1 \quad \text { pescoço } \\
\text { 'meu pescoço' }\end{array}$ & 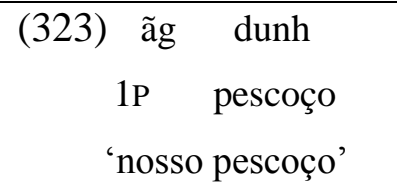 \\
\hline 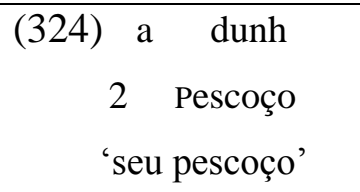 & $\begin{array}{l}\text { (325) mẽ a dunh } \\
\text { 2P pescoço } \\
\text { 'pescoço de vocês' }\end{array}$ \\
\hline 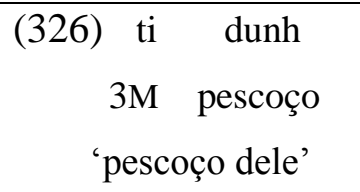 & $\begin{array}{l}\text { (327) zi } \text { dunh } \\
\text { 3F } \text { pescoço } \\
\text { 'pescoço dela' }\end{array}$ \\
\hline $\begin{array}{ccc}\text { (328) } & \text { óg } & \text { dunh } \\
\text { 3P } & \text { pescoço } \\
& \text { 'pescoço deles' }\end{array}$ & \\
\hline
\end{tabular}

'orelha'

\begin{tabular}{|c|c|}
\hline $\begin{array}{l}\text { (329) ẽnh nẽgglãg } \\
1 \quad \text { orelha } \\
\text { 'minha orelha' }\end{array}$ & $\begin{array}{c}\text { (330) ãg nẽgglãg } \\
\text { 1P orelha } \\
\text { 'nossa orelha' }\end{array}$ \\
\hline $\begin{array}{l}\text { (331) a nẽgglãg } \\
2 \text { orelha } \\
\text { 'sua orelha' }\end{array}$ & $\begin{array}{l}\text { (332) mẽ a nẽgglãg } \\
\text { 2P orelha } \\
\text { 'orelha de vocês' }\end{array}$ \\
\hline $\begin{array}{l}\text { (333) ti nẽgglãg } \\
3 \mathrm{M} \text { orelha } \\
\text { 'orelha dele' }\end{array}$ & $\begin{array}{c}\text { (334) zi nẽgglãg } \\
3 \mathrm{~F} \text { orelha } \\
\text { 'orelha dela' }\end{array}$ \\
\hline $\begin{array}{c}\text { (335) óg nẽgglãg } \\
\text { 3P orelha } \\
\text { 'orelha deles' }\end{array}$ & \\
\hline
\end{tabular}

Como mencionamos anteriormente, alguns nomes de partes só se combinam com pronomes de primeira e segunda pessoa quando usados metaforicamente, como é o caso de by 'rabo', que nessa situação significa frigideira, em que by 'rabo' corresponde ao cabo da frigideira, ou seja, a parte representa o todo, como nos processos metonímicos. 
'rabo'

\begin{tabular}{|c|c|}
\hline $\begin{array}{c}\text { (336) ẽnh by } \\
1 \quad \text { rabo } \\
\text { 'meu rabo' }\end{array}$ & 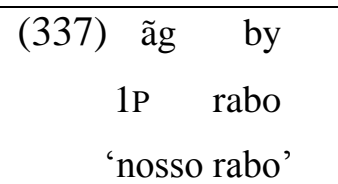 \\
\hline 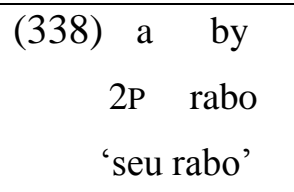 & $\begin{array}{l}\text { (339) mẽ a by } \\
2 \mathrm{P} \text { rabo } \\
\text { 'rabo de vocês' }\end{array}$ \\
\hline 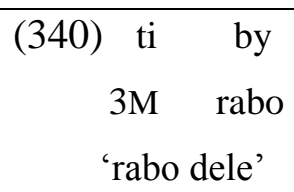 & $\begin{array}{c}\text { (341) } \mathrm{zi} \text { by } \\
\text { 3F rabo } \\
\text { 'rabo dela' }\end{array}$ \\
\hline $\begin{array}{c}\text { (342) óg by } \\
\text { 3P rabo } \\
\text { 'rabo deles' }\end{array}$ & \\
\hline
\end{tabular}

'rabo'

\begin{tabular}{|c|c|}
\hline $\begin{array}{c}\text { (343) kónhjãl by } \\
\text { macaco rabo } \\
\text { 'rabo do macaco' }\end{array}$ & $\begin{array}{c}\text { (344) } \\
\text { pagklo by } \\
\text { 'rabo do peixe' }\end{array}$ \\
\hline $\begin{array}{c}\text { (345) zazan by } \\
\text { tatu rabo } \\
\text { 'rabo do tatu' }\end{array}$ & $\begin{array}{c}(346) \text { txe by } \\
\text { coati rabo } \\
\text { 'rabo do coati' }\end{array}$ \\
\hline $\begin{array}{c}\text { (347) kanhpãglẽ by } \\
\text { lagarto rabo } \\
\text { 'rabo do lagarto' }\end{array}$ & 'rabo do cobra rabo \\
\hline gug by & \\
bugiu rabo & \\
'rabo do bugiu' & \\
\hline
\end{tabular}

'arco'

\begin{tabular}{|c|c|}
\hline $\begin{array}{r}\text { (350) } \text { ẽnh do } \\
1 \quad \operatorname{arco} \\
\text { 'meu arco' }\end{array}$ & 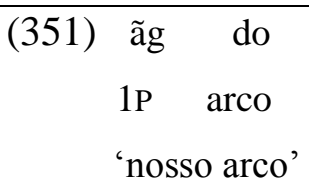 \\
\hline
\end{tabular}




\begin{tabular}{|c|c|}
\hline 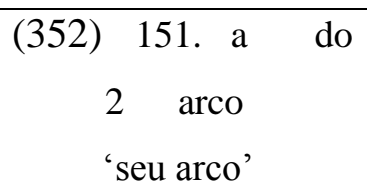 & $\begin{array}{l}\text { (353) mẽ a do } \\
\text { 2P arco } \\
\text { 'arco de vocês' }\end{array}$ \\
\hline 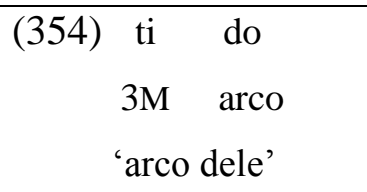 & $\begin{array}{rrr}(355) & \text { zi } & \text { do } \\
3 \mathrm{~F} & \text { arco } \\
\text { 'arco dela' }\end{array}$ \\
\hline 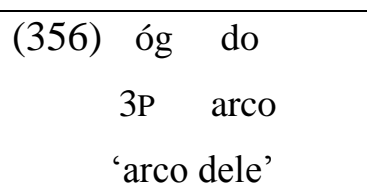 & \\
\hline
\end{tabular}

'cesto'

\begin{tabular}{|c|c|}
\hline $\begin{array}{l}\text { (357) ẽnh kãj } \\
1 \quad \text { cesto } \\
\text { 'meu cesto' }\end{array}$ & $\begin{array}{l}\text { (358) } \text { ãg } \quad \text { kãj } \\
\text { 1P } \quad \text { cesto } \\
\text { 'nosso cesto' }\end{array}$ \\
\hline $\begin{array}{c}\text { (359) a } \quad \text { kãj } \\
2 \text { cesto } \\
\text { 'seu cesto' }\end{array}$ & $\begin{array}{l}\text { (360) mẽ a kãj } \\
\text { 2P cesto } \\
\text { 'seus cestos/ cesto de vocês' }\end{array}$ \\
\hline $\begin{array}{l}\text { (361) ti } \quad \text { kãj } \\
3 \mathrm{M} \text { cesto } \\
\text { 'cesto dele' }\end{array}$ & $\begin{array}{l}\text { (362) } \\
\text { zi }\end{array}$ \\
\hline $\begin{array}{l}\text { (363) óg kãj } \\
\text { 3P cesto } \\
\text { 'cesto deles' }\end{array}$ & \\
\hline
\end{tabular}

'ralador'

\begin{tabular}{|c|c|}
\hline $\begin{array}{c}\text { (364) ẽnh togto loglov } \\
1 \mathrm{P} \quad \text { lata muitos.furos }\end{array}$ & $\begin{array}{c}\text { (365) ãg togto loglov } \\
1 \mathrm{P} \quad \text { lata muitos.furos } \\
\text { 'meu ralador' }\end{array}$ \\
\hline $\begin{array}{c}\text { (366) a togto loglov ralador' } \\
2 \text { lata muitos.furos }\end{array}$ \\
'seu ralador' & mẽ a togto loglov \\
'ralador de vocês'
\end{tabular}




\begin{tabular}{|l|l|}
\hline 3P lata muitos.furos & \\
'ralador deles' & \\
\hline
\end{tabular}

'pilão'

\begin{tabular}{|c|c|}
\hline $\begin{array}{c}\text { (371) ẽnh kléj } \\
1 \quad \text { pilão } \\
\text { 'meu pilão' }\end{array}$ & $\begin{array}{l}\text { (372) ãg kléj } \\
\text { 1P pilão } \\
\text { 'nosso pilão' }\end{array}$ \\
\hline $\begin{array}{c}\text { (373) a kléj } \\
2 \text { pilão } \\
\text { 'seu pilão' }\end{array}$ & $\begin{array}{l}\text { (374) mẽ a kléj } \\
\text { 2P pilão } \\
\text { 'pilão de vocês' }\end{array}$ \\
\hline $\begin{array}{l}\text { (375) ti kléj } \\
3 \mathrm{M} \text { pilão } \\
\text { 'pilão dele' }\end{array}$ & $\begin{array}{c}\text { (376) zi } \quad \text { kléj } \\
\text { 3F pilão } \\
\text { 'pilão dela' }\end{array}$ \\
\hline $\begin{array}{c}\text { (377) óg } \quad \text { kléj } \\
\text { 3P pilão } \\
\text { 'pilão deles' }\end{array}$ & \\
\hline
\end{tabular}

'mão de pilão'

\begin{tabular}{|c|c|}
\hline $\begin{array}{l}\text { (378) ẽnh } \quad \text { kló } \\
1 \text { mão de pilão } \\
\text { 'minha mão de pilão' }\end{array}$ & $\begin{array}{l}\text { (379) ãg } \quad \text { kló } \\
\text { 1P mão de pilão' } \\
\text { 'nossa mão de pilão' }\end{array}$ \\
\hline $\begin{array}{l}\text { (380) a } \\
2 \text { mão de pilão } \\
\text { 'sua mão de pilão' }\end{array}$ & $\begin{array}{l}\text { (381) mẽ a kló } \\
\text { 2P mão de pilão } \\
\text { 'mão de pilão de vocês' }\end{array}$ \\
\hline $\begin{array}{l}\text { (382) ti } \quad \text { kló } \\
3 \mathrm{M} \text { mão de pilão } \\
\text { 'mão de pilão dele' }\end{array}$ & $\begin{array}{l}\text { (383) zi } \quad \text { kló } \\
\text { 3F mão de pilão } \\
\text { 'mão de pilão dela' }\end{array}$ \\
\hline $\begin{array}{l}\text { (384) óg kló } \\
\text { 3ão de pilão } \\
\text { 'mão de pilão deles' }\end{array}$ & \\
\hline
\end{tabular}


'colar'

\begin{tabular}{|c|c|}
\hline $\begin{array}{c}\text { (385) ẽnh zãnkó } \\
1 \quad \text { colar } \\
\text { 'meu colar' }\end{array}$ & $\begin{array}{c}\text { (386) ãg zãnkó } \\
\text { 1P colar } \\
\text { 'nosso colar' }\end{array}$ \\
\hline $\begin{array}{l}\text { (387) } 185 . \text { a } \text { zãnkó } \\
2 \text { colar } \\
\text { 'seu colar' }\end{array}$ & $\begin{array}{l}\text { (388) mẽ a zãnkó } \\
\text { 2P colar } \\
\text { 'colar de vocês' }\end{array}$ \\
\hline $\begin{array}{c}\text { (389) ti zãnkó } \\
\text { 3P colar } \\
\text { 'colar dele' }\end{array}$ & $\begin{array}{c}\text { (390) zi zãnkó } \\
\text { 3F colar } \\
\text { 'colar dela' }\end{array}$ \\
\hline $\begin{array}{c}\text { (391) óg zãnkó } \\
\text { 3P colar } \\
\text { 'colar deles' }\end{array}$ & \\
\hline
\end{tabular}

'capacete'

\begin{tabular}{|c|c|}
\hline $\begin{array}{l}\text { (392) ẽnh klẽ pũdél } \\
1 \text { cabeça capacete } \\
\text { 'meu capacete' }\end{array}$ & $\begin{array}{c}\text { (393) ãg glẽ pũdél } \\
\text { 1P cabeça capacete } \\
\text { 'nosso capacete' }\end{array}$ \\
\hline $\begin{array}{l}\text { (394) a klẽ pũdél } \\
2 \text { cabeça capacete } \\
\text { 'seu capacete' }\end{array}$ & $\begin{array}{l}\text { (395) mẽ a klẽ pũdél } \\
\text { 2P cabeça capacete } \\
\text { 'capacete de vocês' }\end{array}$ \\
\hline $\begin{array}{l}\text { (396) ti klẽ pũdél } \\
\text { 3M cabeça capacete } \\
\text { 'capacete dele' }\end{array}$ & $\begin{array}{l}\text { (397) zi klẽ pũdél } \\
\text { 3F cabeça capacete } \\
\text { 'capacete dela' }\end{array}$ \\
\hline $\begin{array}{c}\text { (398) óg klẽ pũdél } \\
\text { 3P cabeça capacete } \\
\text { 'capacete deles' }\end{array}$ & \\
\hline
\end{tabular}

'tanga'

\begin{tabular}{|c|c|}
\hline $\begin{array}{l}\text { (399) ẽnh vãzẽzẽ } \\
1 \quad \text { tanga } \\
\text { 'minha tanga' }\end{array}$ & $\begin{array}{c}\text { (400) ãg vãzẽzẽ } \\
\text { 1P tanga } \\
\text { 'nossa tanga' }\end{array}$ \\
\hline
\end{tabular}




\begin{tabular}{|c|c|}
\hline \begin{tabular}{|c|} 
(401) a vãzẽzẽ \\
$2 \quad$ tanga
\end{tabular} & $\begin{array}{c}\text { (402) mẽ a vãzẽzẽ } \\
\text { 'P tanga } \\
\text { 'tanga de vocês' }\end{array}$ \\
(403) ti vãzãzẽ & $(404)$ zi vãzẽzẽ \\
'tanga dele' & 3F tanga \\
'tanga dela' \\
305 tanga vãzẽzẽ & \\
'tanga deles' & \\
\hline
\end{tabular}

'mãe'

\begin{tabular}{|c|c|}
\hline $\begin{array}{l}\text { (406) ẽnh jõ zi } \\
1 \text { mãe } \mathrm{MG} \\
\text { 'minha mãe' }\end{array}$ & $\begin{array}{c}\text { (407) } \text { ãg jõ } \quad \text { zi } \\
\text { 1P mãe } \quad \text { MG } \\
\text { 'nossa mãe' }\end{array}$ \\
\hline 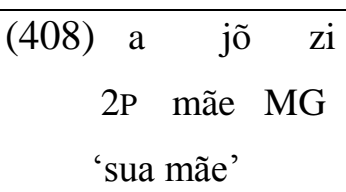 & $\begin{array}{l}\text { (409) mẽ a jõ zi } \\
\text { 2Pp mãe MG } \\
\text { 'mãe de vocês' }\end{array}$ \\
\hline 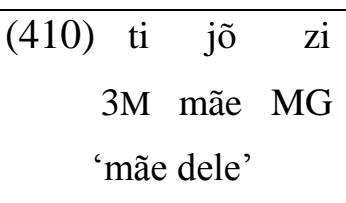 & 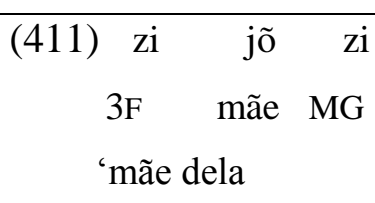 \\
\hline $\begin{array}{l}\text { (412) óg jõ zi } \\
\text { 3P mãe MG } \\
\text { 'mãe deles' }\end{array}$ & \\
\hline
\end{tabular}

'pai'

\begin{tabular}{|c|c|}
\hline $\begin{array}{c}\text { (413) } \text { ẽnh jug } \\
1 \quad \text { pai } \\
\text { 'meus pai' }\end{array}$ & $\begin{array}{c}\text { (414) } \text { ãg } \quad \text { jug } \\
\text { 1P pai } \\
\text { 'nosso pai' }\end{array}$ \\
\hline $\begin{array}{c}\text { (415) a } \quad \text { jug } \\
2 \quad \text { pai } \\
\text { 'seu pai' }\end{array}$ & $\begin{array}{l}\text { (416) mẽ a jug } \\
\text { 2P pai } \\
\text { 'pai de vocês' }\end{array}$ \\
\hline
\end{tabular}




\begin{tabular}{|c|c|}
\hline $\begin{array}{c}\text { (417) ti jug } \\
3 \mathrm{M} \text { pai }\end{array}$ & $\begin{array}{c}\text { (418) } \text { zi jug } \\
\text { 'pai dele' }\end{array}$ \\
'pai dela' \\
(419) óg jug pai & \\
'pai deles' & \\
\hline
\end{tabular}

'filho (mulher ou homem falando)'

\begin{tabular}{|c|c|}
\hline $\begin{array}{r}\text { (420) } \\
\text { ẽnh } \quad \text { ji } \\
1 \quad \text { filho } \\
\text { 'meu filho' }\end{array}$ & $\begin{array}{crr}\text { (421) } & \text { ãg } & \text { ji } \\
\text { 1P } & \text { filho } \\
& \text { 'nosso pai' }\end{array}$ \\
\hline 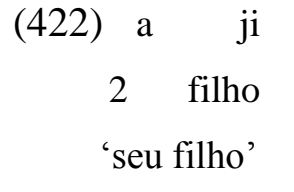 & $\begin{array}{l}\text { (423) mẽ a } \mathrm{ji} \\
2 \mathrm{P} \text { filho } \\
\text { 'pais de vocês' }\end{array}$ \\
\hline $\begin{array}{l}\text { (424) } \mathrm{ti} \quad \mathrm{ji} \\
3 \mathrm{M} \quad \text { filho } \\
\text { 'filho dele }\end{array}$ & $\begin{array}{l}\text { (425) } \text { zi } \quad \text { ji } \\
\text { 3F filho } \\
\text { 'filho dela' }\end{array}$ \\
\hline $\begin{array}{l}\text { (426) óg ji } \\
\text { 3P filho } \\
\text { 'filho deles' }\end{array}$ & \\
\hline
\end{tabular}

'filha (mulher ou homem falando)'

\begin{tabular}{|c|c|}
\hline $\begin{array}{l}\text { (427) ẽnh ji zi } \\
1 \text { filho } \mathrm{MG} \\
\text { 'minha filha' }\end{array}$ & $\begin{array}{c}\text { (428) ãg ji zi } \\
\text { 1P filho MG } \\
\text { 'nossa filha' }\end{array}$ \\
\hline 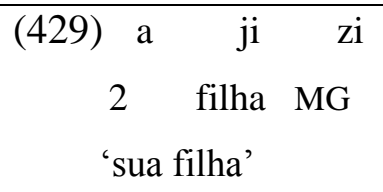 & $\begin{array}{l}\text { (430) mẽ a ji zi } \\
\text { 2P filho MG } \\
\text { 'filha de vocês' }\end{array}$ \\
\hline $\begin{array}{lrr}\text { (431) } & \text { ti } \text { ji } & \mathrm{zi} \\
3 \mathrm{M} \text { filho } & \mathrm{MG} \\
\text { 'filha dele' } & \end{array}$ & 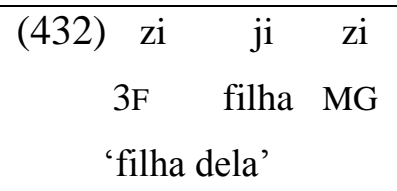 \\
\hline
\end{tabular}




\begin{tabular}{|l|l|}
\hline (433) óg ji zi & \\
3P filho MG & \\
'filha deles' & \\
\hline
\end{tabular}

Exemplos de nomes da subclasse $1 \mathrm{~b}$ combinados com outros nomes, ou seja, construções em que o determinante é um nome e o determinado outro nome:

(434) Kãggunh jãnky

nom. masc. boca

'boca de Kãggunh'

(435) Ãmẽdo zi jãnky

nom. fem. MGboc a'

'boca de Âmẽdo'

(436) kójãl klẽ

macaco cabeça

'cabeça de macaco'

(437) zazan by

tatu rabo

'rabo do tatu'

(438) kugklũ tõ kuhol

panela TRANS argila

'panela de argila'

(439) jug nũgjẽn

pai irmão

'irmão do meu pai' 


\subsubsection{Nomes relativos da subclasse $1 b$}

Nomes relativos da subclasse $1 \mathrm{~b}$ nunca se combinam com pronomes, porque são partes de outras partes do corpo de humanos ou de animais. Estes são nomes como: by 'rabo', glu, klu 'unha', zéj 'dedo', glóg 'articulação', kágki 'cabelo, pena'.

Alguns exemplos contextualizados desses nomes são:

(440) a jãlã kágki

2 axila pelo/cabelo

'pelo de sua axila'

(441) ti jãlã kágki

$3 \mathrm{M}$ axila pelo/cabelo

'pelo da axila dele'

(442) zi jãlã kágki

3F axila pelo/cabelo

'pelo da axila dela'

(443) ãg jãlã kágki

1P axila pelo/cabelo

'pelo de nossa axila'

(444) mẽ a jãlã kágki

2P axila pelo/cabelo

'pelo da axila de vocês'

(445) óg jãlã kágki

3P axila pelo/cabelo

'pelo da axila deles' 
(446) ẽnh kónã jukig

1 olho cílios

'meu cílios'

(447) ẽnh klẽ kágki

1 cabeça cabelo/pelo

'meu cabelo'

(448) a klẽ kágki

2 cabeça cabelo/pelo

'seu cabelo/ cabelo de sua cabeça'

(449) ti klẽ kágki

3M cabeça cabelo/pelo

'cabelo dele'

(450) zi klẽ kágki

3F cabeça cabelo/pelo

'cabelo dela'

(451) ãg klẽ kágki

1P cabeça cabelo/pelo

'nosso cabelo'

(452) mẽ a klẽ kágki

2P cabeça cabelo/pelo

'cabelo de vocês'

(453) óg klẽ kágki

3P cabeça cabelo/pelo

'cabelo deles' 
(454) ẽnh jẽgga zéj

1 mão dedo

'dedo de minha mão'

(455) a nẽgga zéj
2 mão dedo
'dedo de sua mão'

(456) ti nẽgga zéj

3M mão dedo

'dedo da mão dele'

(457) zi nẽgga zéj

3F mão dedo

'dedo da mão dela'

(458) ãg nẽgga zéj

1P mão dedo

'dedo da nossa mão'

(459) mẽ a nẽgga zéj

2P mão dedo

'dedo da mão de vocês'

(460) óg nẽgga zéj

3P mão dedo/folha

'dedo da mão deles'

'unha da mão'

(461) ẽnh jẽgga klẽnhglu

1 mão unha

'unha de minha mão' 
(462) a nẽgga klẽnhglu

2 mão unha

'unha de sua mão'

(463) ti nẽgga klẽnhglu

3P mão unha

'unha da mão dele'

(464) zi nẽgga klẽnhglu

3F mão unha

'unha da mão dela'

(465) ãg nẽgga klẽnhglu

1P mão unha

'unha da nossa mão'

(466) mẽ a nẽgga klẽnhgl

2P mão unha

'unha da mão de vocês'

(467) óg nẽgga klẽnhglu

3PP mão unha

'unha da mão deles'

'unha do pé'

(468) ẽnh pãn klẽnhglu

1 pé unha

'minha unha do pé'

(469) a pãn klẽnhglu

2 pé unha

'sua unha do pé' 
(470) ti pãn klẽnhglu

$3 \mathrm{M}$ pé unha

'unha do pé dele'

(471) zi pãn klẽnhglu

$3 \mathrm{~F}$ pé unha

'unha do pé dela'

(472) ãg pãn klẽnhglu

2P pé unha

'unha de nossos pés'

(473) mẽ a pãn klẽnhglu

2P pé unha

'unha dos pés de vocês'

(474) óg pãn klẽnhglu

3P pé unha

'unha dos pés deles'

'cílios'

(475) ẽnh kónã jugkig

1 olho cílios

'meus cílios/ silos do meu olho'

(476) a kónã jugkig

2 olho cílios

'seus cílios/ cílios do seu olho'

(477) ti kónã jugkig

3M olho cílios

'cílios dele/ cílios do olho dele' 
(478) zi kónã jugkig

3F olho cílios

'cílios dela/ cílio do olho dela'

\subsubsection{Nomes da subclasse 2}

Os nomes da subclasse 2, como já explicamos anteriormente, são [- relativo, + absoluto]. Distinguem-se dos demais nomes, pois podem entrar em uma relação de posse possuídos por meio de um nome classificador genérico. Há em Laklãnõ um só nome classificador genérico mãg, equivalente a xerimbabo, que serve de mediador de determinação nominal de nomes de animais. Exemplos desse tipo de construção são os seguintes:

Exemplos com mãg

(479) ẽn mãg tõ katxol

1 criação TRANS cachorro

'meu xerimbabo cachorro'

(480) ẽnh mãg tõ glun

1 xerimbabo TRANS gato 'meu xerimbabo gato'

(481) ẽnh mãg tõ kójãl

1 xerimbabo TRANS macaco

'meu xerimbabo macaco'

(482) ẽnh mãg tõ txãggõnh

1 xerimbabo TRANS passarinho

'meu xerimbabo pássaro' 
(483) ẽnh mãg tõ txe
1 xerimbabo TRANS quati
'meu xerimbabo quati'

(484) ẽnh mãg tõ kugkév

1 xerimbabo TRANS galinha

'meu xerimbabo galinha'

(485) ẽnh mãg tõ ugby

1 xerimbabo TRANS porco

'meu xerimbabo porco'

(486) ẽnh mãg tõ kãvãlu

1 xerimbabo TRANS cavalo'

'meu xerimbabo cavalo'

(487) ẽnh mãg tõ nẽkóbág

1 xerimbabo TRANS boi

'meu xerimbabo boi'

Nesse tipo de construção, o núcleo é seguido do morfema genitivo tõ, que, por sua vez, é seguido do nome que especifica o animal de criação. Já o nome do animal é usado com uma função atributiva.

Consideramos o nome mãg um nome classificador de todos os animais que podem exercer a função de xerimbabo do homem.

\subsubsection{Nomes da subclasse 3}

Nomes da subclasse 3 são nomes de sensações, cujos referentes são [- relativo, + absoluto].

Em Laklãnõ não se pode dizer "meu frio" porque é considerado um fenômeno da natureza que apenas causa sensação a alguém, de forma que se alguém sente frio, diz-se que 
há frio com respeito a alguém. Assim as construções envolvendo palavras como 'frio' são do tipo 'existe frio' com respeito a algo ou alguém, como mostram os seguintes exemplos:

(488) ẽnh jõ kutxó kó

1 POSP frio exist

'existe frio para mim' ('eu estou com frio’)

(489) a mõ kutxó vã

2 POSP frio ESTAT

'existe frio com respeito a você'('você está sentindo frio')

(490) ti mõ kutxó vã

$3 \mathrm{P}$ POSP frio ESTAT

'existe frio com respeito a ele' ('ele está sentindo frio')

(491) zi mõ kutxó vã

3F POSP frio ESTAT

'existe frio com respeito a ela' / ela está sentindo frio'

(492) ẽnh jõ laglẽl kó

1 POSP calor exist

'eu estou com calor/existe calor com respeito a mim'

\subsubsection{Estado de existência dos referentes dos nomes}

Seguindo Rodrigues (2001) e Rodrigues e Cabral (2012) sobre o estado de existência de referentes de nomes em línguas Tupí, consideramos que também em Laklãnõ os nomes são marcados pelo estado de existência dos seus respectivos referentes: estado atual, estado retrospectivo e estado prospectivo. $\mathrm{O}$ estado atual é aquele em que a existência do referente está atualizada, tem existência em um momento dado. Este é o estado não marcado. O retrospectivo é o estado em que o referente já não existe, sendo marcado por jó. Finalmente, o estado prospectivo é aquele em que se projeta a existência de um referente, marcando-o o nome com ke. Os exemplos seguintes ilustram os três estados de existência dos referentes dos nomes. 
Quadro 6 - Os três estados de existência dos referentes dos nomes.

\begin{tabular}{|l|l|l|l|}
\hline Atual & Retrospectivo & Prospectivo & Nome \\
\hline ẽn & ẽn jó & ẽn ke & 'casa' \\
\hline jópõ & jópõ jó & jópõ ke & 'roça' \\
\hline ãmẽn & ãmẽn jó & ãmẽn ke & 'caminho' \\
\hline ulé & ulé jó & ulé ke & 'lagoa' \\
\hline blo & blo jó & blónh ke & 'banhar' \\
\hline kute & kute jó & kute ke & 'mato' \\
\hline kãj & kãj jó & kãj ke & 'cesto' \\
\hline vyj & vyj jó & vyj ke & 'arco' \\
\hline kózy & kózy jó & kózy ke & 'pedra' \\
\hline bég & bég jó & bég ke & 'machado' \\
\hline kul & kul jó & kul ke & 'roupa' \\
\hline kãgkénh & kãgkénh jó & kãgkénh ke & 'canoa' \\
\hline klãgdja & klãgdja jó & klãgdja ke & 'faca' \\
\hline do & do jó & do ke & 'flecha' \\
\hline kugklũ & kugklũ jó & kugklũ ke & 'panela' \\
\hline kãnhglẽ & kãnhglẽ jó & kãnhglẽ ke & 'foice' \\
\hline kutyg & kutyg jó & kutyg ke & 'noite' \\
\hline kutxó & kutxó jó & kutxó ke & 'frio' \\
\hline kájo & kájo jó & kájo ke & 'magro' \\
\hline txá & kózéj jó & txá ke & 'flor' \\
\hline kupli & kupli ke & kózéj ke \\
\hline kózéj & lõnhlõj ke & \\
\hline lõnhlõj jó & & \\
\hline
\end{tabular}

Salientamos que as marcas de estado de existência ocorrem antes da marca de gênero:

(493) glun tõ tá lá txá jó zi vã GATO TRANS fêmea pintado preto RETR MG ESTAT 'ex-gato fêmea pintado preto'

(494) kálõ tõ tá katxin txá jó zi vã cutia TRANS fêmea pequeno preto retrosp MG ESTAT 
'ex-cutia preta pequena'

(495) katxove tõ tá lá jó zi vã graxaim TRANS fêmea pintado RETR MG ESTAT 'ex-cachorra do mato pintada'

(496) kãvãlu tõ tá kupli katxin jó zi vã cavalo TRANS fêmea branco pequeno RETR MG ESTAT 'ex-cavalo branco pequeno'

(497) katxol tõ tá txá kájo pãn téj jó zi vã cachorro TRANS fêmea preto magro pé comprido RETR MG ESTAT 'ex-cachorra preto magro perna comprida'

(498) glun tõ tá lá txá ke zi vã gato TRANS fêmea pintado preto POSP MG ESTAT 'ex-gato pintado preto'

(499) kálõ tõ tá katxin txá ke zi vã cutia TRANS fêmea pequeno preto PROSP MG ESTAT 'ex-cutia preta pequena'

(500) katxove tõ tá lá ke zi vã graxaim TRANS fêmea pintado PROSP MG ESTAT 'ex-cachorra do mato pintado'

(501) kavãlu tõ tá kupli katxin ke zi vã cavalo TRANS fêmea branco pequeno PROSP MG ESTAT 'ex-égua branca pequeno'

(502) katxol tõ tá txá kájo pãn téj ke zi vã cachorro TRANS fêmea preto magro pé comprido PROSP MG ESTAT 'ex-cachorro preto magro perna comprida'

\subsubsection{Gênero}


$\mathrm{Na}$ língua Laklãnõ, a distinção de gênero masculino e feminino é muito importante. Essa distinção existe lexicalmente nos próprios nomes de pessoas, que se dividem em masculinos e femininos. Os homens não podem receber nomes femininos, nem as mulheres nomes masculinos. Listamos a seguir alguns nomes masculinos e femininos do Laklãnõ:

Quadro 7 - Nomes masculinos e femininos

\begin{tabular}{|c|c|}
\hline Nome Masculino & Nome Feminino \\
\hline Kãggunh & Ãmẽdo zi \\
\hline Zágpopẽ & Tálé zi \\
\hline Mõgkónã & Nũgtẽg zi \\
\hline Zẽzẽ & Gávẽn zi \\
\hline Kagdan & Vãnká zi \\
\hline Pazi & Vãkla zi \\
\hline Tucun & Txulunh zi \\
\hline Dil & Kógta zi \\
\hline Váia & Kulé zi \\
\hline Kapil & Zágtxo zi \\
\hline Zetxa & Van zi \\
\hline Juplu & Du' ug zi \\
\hline Vãnhla & Vãnhómẽ zi \\
\hline Kóvi & Kudin zi \\
\hline
\end{tabular}

De um modo geral, nomes, próprios ou não, se possuem referentes humanos, sendo seus respectivos referentes masculinos, não são marcados, mas os nomes com referentes femininos recebem a marca $z i$. Esta marcacão só é feita em nomes de referentes [+ animado].

A marca de gênero feminino corresponde, por sua vez, à forma da $3^{\mathrm{a}}$ pessoa do gênero feminino.

Em seguida, exemplificamos a ocorrência de marca de gênero feminino: 
(503) ãmẽdo zi vũ kutã MŨ

nom. fem. MG ms cair PERF

'ãmẽdo caiu'

(504) lag zi vũ blo jã

nom. fem. MG ms banho AUX.1

'lag está tomando banho'

(505) kógté zi kutã vã

nom. fem. MG cair ESTAT

'kógta está caindo'

(506) kulé zi vũ lanhlanh nẽ

nom. fem. MG MS trabalha AUX.2

'kula está trabalhando sentada'

(507) telé zi vũ tẽ tẽ

nom. fem. MG MS ir IMPERF

'tálé vai embora'

No que diz respeito aos animais, os nomes que os designam só recebem a marca $z i$ se estiverem combinados com a palavra para fêmea. Comparem-se os exemplos seguintes:

(508) ẽnh mãg tõ ugby tõ kónhgág vũ ty mũ 1P criação TRANS porco TRANS macho MS morrer PERF 'minha criação porco macho morreu'

(509) ẽnh mãg tõ ugby tõ tá zi vũ kóggó jã 1 criação TRANS porco TRANS fêmea MG MS doente AUX.1 'minha criação porco fêmea ela está doente' 
(510) a mãg tõ ugby tõ kónhgág vũ tag jã

2 criação TRANS porco TRANS macho MS gordo AUX.1

'sua criação porco macho está morrendo'

(511) a mãg tõ ugby tõ tá zi vũ ty mũ

2 criação TRANS porco TRANS fêmea MG MS morrer PERF 'sua criação porco fêmea morreu’

(512) ti mãg tõ ugby tõ kónhgág vũ txá jã 3M criação TRANS porco TRANS macho MS preto AUX.1 'criação dele porco macho é preta'

(513) ti mãg tõ ugby tõ tá zi vũ kóggó jã 3M criação TRANS porco TRANS fêmea MG MS doente AUX.1 'criação dele porco fêmea está doente'

(514) zi mãg tõ ugby tõ kónhgág vũ kutã MŨ 3F criação TRANS porco TRANS macho MS cair PERF 'criação dela porco macho caiu'

(515) zi mãg tõ ugby tõ tá zi vũ ty MŨ 3F criação TRANS porco TRANS fêmea MG MS morrer PERF 'criação dela porco fêmea ela morreu'

(516) ẽnh mãg tõ glun tõ kónhgág vũ bág nẽ 1 criação TRANS gato TRANS macho MS ADV AUX.2 'minha criação gato macho é grande'

(517) ẽnh mãg tõ glun tõ tá zi vũ kájo nẽ 1 criação TRANS gato TRANS fêmea MG MS magro AUX.2 'minha criação gato fêmea ela é magra' 
(518) a mãg tõ glun tõ tá zi vũ kóggó nẽ

2 criação TRANS gato TRANS fêmea MG MS doente AUX.2

'sua criação gato fêmea ela está doente'

(519) ti mãg tõ glun tõ tá zi vũ bág nẽ 3M criação TRANS gato TRANS fêmea MG MS grande AUX.2 'criação dele gato fêmea ela é grande'

(520) zi mãg tõ glun tõ tá zi vũ ty mũ 3F criação TRANS gato TRANS fêmea MG MS morrer PERF 'criação dela gato fêmea ela morreu'

(521) ẽnh mãg tõ ugby tõ kónhgág vũ txá jã 1 criação TRANS porco TRANS macho MS preto AUX.1 'minha criação porco macho é preto'

(522) a mãg tõ ugby tõ kónhgág vũ dén ko jã 2 criação TRANS porco TRANS macho MS algo comer AUX.1 'sua criação porco macho está comendo'

(523) ti mãg tõ ugby tõ kónhgág vũ kutã MŨ 3M criação TRANS porco TRANS macho MS cair PERF 'criação dele porco macho caiu'

(524) zi mãg tõ ugby tõ kónhgág vũ kupli jã 3F criação TRANS porco TRANS macho MS branco AUX.1 'criação dela porco macho é branco'

(525) ãg mãg tõ ugby tõ kónhgág vũ pãn téj jã 1P criação TRANS porco TRANS macho MS pé comprido AUX.1 'nosso criação porco macho é comprido' 
(526) mẽ a mãg tõ ugby tõ kónhgág vũ kutxug jã' 2P criação TRANS porco TRANS macho MS vermelho AUX.1 'criação de vocês porco macho é vermelho'

(527) óg mãg tõ ugby tõ kónhgág vũ kabág nõdẽ 3P criação TRANS porco TRANS macho MS bastante AUX.1 (pl.) 'criação deles porco macho são bastante'

(528) glun tõ tá zi vũ klã nẽ gato TRANS fêmea MG MS prenha AUX.1

'a gata fêmea está prenha'

(529) glun tõ kónhgág vũ lá nẽ gato TRANS macho MS pintada AUX.2

'gato macho é pintado'

(530) gug tõ tá zi vũ txá nẽ bugio TRANS fêmea MG MS preto AUX.2 'a gata fêmea é preta'

(531) glun tõ kónhgág vũ lãg MŨ gato TRANS macho MS pular PERF 'gato macho pulou'

(532) kabe tõ tá zi vũ katxin jã veado TRANS fêmea MG MS pequeno AUX.1 'a veada fêmea é pequena'

(533) kabe tõ kónhgág vũ kájo jã veado TRANS macho MS magro AUX.1 'veado macho ele é magro' 
(534) kálõ tõ tá zi vũ bág nẽ cutia TRANS fêmea MG MS grande AUX.2

'a cutia fêmea ela é grande'

(535) katxol tõ tá zi vũ tag jã cachorro TRANS femea MG MS gorda AUX.1

'a cachorra femea ela é gorda'

(536) zujin tõ tá zi vũ lãg MŨ ouriço TRANS fêmea MG MS pular PERF 'a ouriço femea ela pulou'

(537) klẽdjunh tõ tá zi vũ gal ko nẽ capivara TRANS femea MG MS milho comer AUX.2 'a capivara femea ela está comeu milho'

(538) ujol tõ tá zi vũ nẽ kũ nẽ anta TRANS femea MG MS estar $\mathrm{Cj}$ AUX.2 'a anta femea ela está sentada'

(539) zazan tõ tá zi vũ ty mũ tatu TRANS femea MG MS morre PERF 'a tatu femea ela morreu'

(540) txe tõ tá zi vũ lá nẽ quati TRANS femea 3F MS pintada AUX.2 'a quati fêmea ela é pintada'

\subsubsection{Número}

Há duas formas de expressar número em Laklãnõ: acrescentando ó $\boldsymbol{g}$ ao nomes cujos referentes são [+ humanos], e acrescentando kabág a nomes com referentes [- humanos]. 


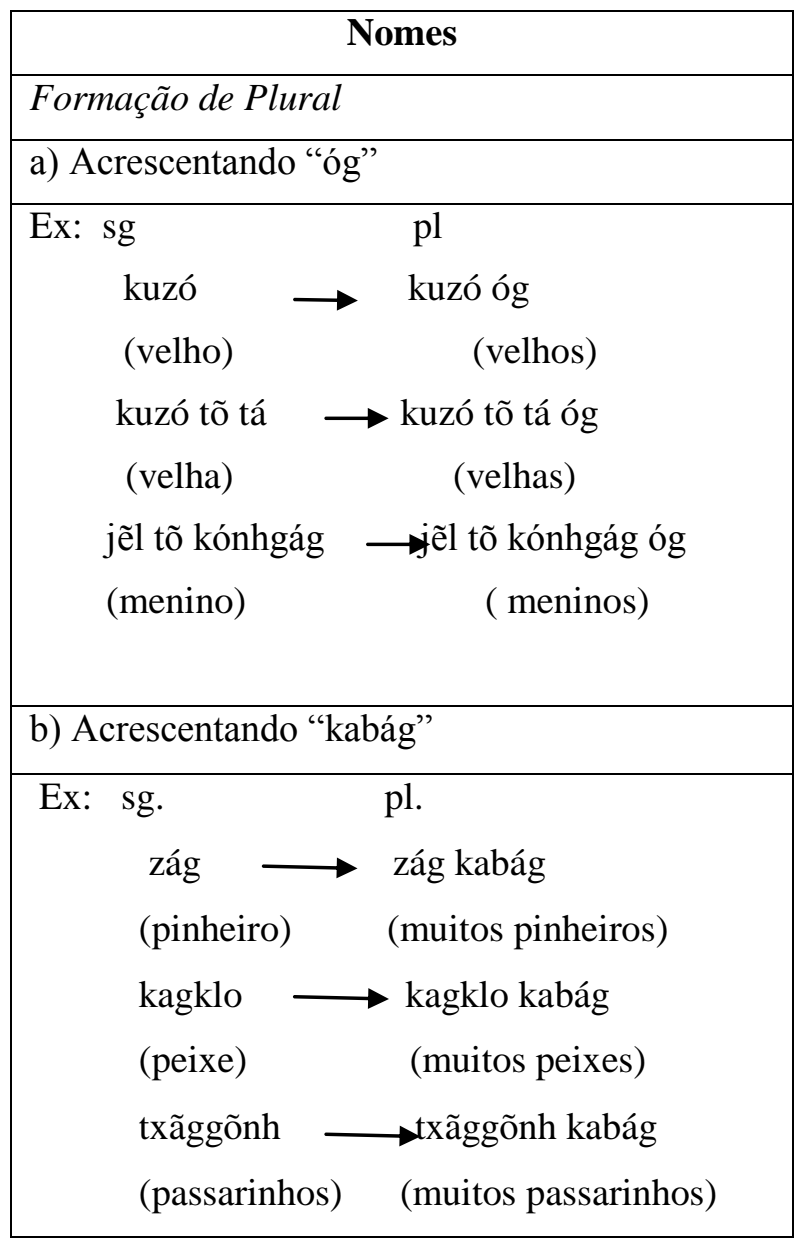

\subsubsection{Nomes de quantidade}

Dentre os nomes de quantidade estão os nomes que correspondem a palavras numerais do português, por exemplo.
(541) pil
'sozinho'
(542) légle
'gêmeo'
(543) légle to pil 'gêmeo e um'
(544) légle to halike 'gêmeo com igual'
(545) tag tũ 'porção pequena'
(546) zõm
'porção grande'

Como pode ser visto, esses nomes são equivalentes a conceitos de numerais em Português, embora não sejam verdadeiramente numerais: 
(547) pil 'sozinho' $=$ um

(548) légle 'gêmeo' = dois

(549) légle to pil 'gêmeo e um' = três

(550) légle to halike 'gêmeo com igual' = quatro

(551) tag tugtũ 'porção pequena' = porção pequena

(552) zõm 'porção grande' = porção grande

Esses nomes quantificadores seguem os nomes núcleo, como em:

(553) Gẽl pil - 'um menino' ou 'menino sozinho'

(554) ẽnh pil nũ jã - ' 'eu só eu estou'

(555) jẽl légle - 'gêmeo'

(556) jẽl kónhgág légle - ' 'gêmeos meninos machos'

\subsubsection{Demonstrativos}

Há três demonstrativos em Laklãnõ, os quais contrastam em termos de distância do elemento indicado e de sua visibilidade com relação ao centro dêitico, que é o falante:

\begin{tabular}{|c|c|c|}
\hline + perto do falante, + visível & - perto do falante, + visível & $\begin{array}{l}\text { - perto do falante, +/ - } \\
\text { visível, entre outros }\end{array}$ \\
\hline tóg & hã ta & ũ ta \\
\hline
\end{tabular}

Os demonstrativos, quando ocorrem modificando uma expressão nominal, seguem imediatamente o núcleo, ou o atributo destes:

tóg

(557) kózy tóg vũ tapél nẽ

pedra DEM MS chato AUX.2

'esta pedra é chata' 
(558) kul txá tóg vũ u nẽ roupa preta DEM MS bonito AUX.2

'esta roupa preta é bonita'

(559) glun tõ tá tóg zi vũ tag nẽ gato TRANS femea DEM MG MS gordo AUX.

'esta gata femea está gorda'

Outros exemplos com tóg

(560) ugby tóg vũ tag jã

porco DEM MS gordo AUX.1

'este porco é gordo'

(561) ẽn tóg vũ u tavẽ jã

casa DEM MS bonito INTENS AUX.1

'esta casa é muito bonit a'

(562) dén kónã tóg vũ kugklé nẽ

algo fruta DEM MS podre AUX.2

'esta fruta é podre'

(563) katxol tóg vũ kujel jã

cachorro DEM MS fome AUX.1

'este cachorro está com fome'

(564) klãdja tóg vũ $u$ nõ

faca DEM MS bonita AUX.2

'esta faca é bonita'

(565) ujol tóg vũ kájo jã

anta DEM MS magro AUX.1

'esta anta é magra' 
(566) gug tóg vũ tag nẽ

bugio DEM MS gordo AUX.2

'este bugio é gordo'

(567) goj tóg vũ tõdig tẽ

água dem MS fundo IMPERF

'este rio é fundo'

\section{$h \tilde{a}$ ta}

(568) kul txá hã ta vũ u nẽ

roupa preto DEM MS bonito AUX.2

'aquela roupa era bonita'

(569) kózy hã ta vũ tapel nẽ

pedra DEM MS chato AUX.2

'aquela pedra era bonita'

(570) ugby hã ta vũ tag jã

porco DEM MS gordo AUX.1

'aquele porco era gordo'

(571) ẽn hã ta vũ u tavẽ jã

casa DEM MS bonito INTENS AUX.1

'aquela casa era muito bonita'

(572) glun tõ tá hã ta zi vũ tag nẽ

gato TRANS femea DEM MG MS gordo AUX.2

'aquela gata femea era gorda'

(573) dén kónã hã ta vũ kugklé nẽ

algo fruta DEM MS podre AUX.2 
'aquela fruta era podre'

(574) katxol hã ta vũ kujel jã

cachorro DEM MS fome AUX.

'aquele cachorro estava com fome'

(575) klãdja hã ta vũ u nõ

faca DEM MS bonito AUX.2

'aquela faca era bonito'

(576) ujol hã ta vũ kájo jã

anta DEM MS magro AUX.

'aquela anta era gorda'

(577) gug hã ta vũ tag nẽ

bugio DEM MS gordo AUX.2

'aquele bugio era gordo'

(578) ẽn hã ta vũ pũl mũ

casa dem MS queimar PERF

'aquela casa queimou'

\section{$\tilde{u} t a$}

(579) kónhgág ũ ta vũ ty mũ

homem DEM MS morrer PERF

'aquele outro homem morreu'

(580) ũ ta vũ ko nõ

dem MS comer AUX.2

'aquela outra está comendo/aquele ouro está comendo deitado'

(581) kónhgág ũ ta ta vũ zi blé dén ko mũ homem DEM 3P MS 3F POSP algo comer PERF 'aquele outro homem comeu algo com ela' 
(582) jẽl ũ ta vũ ẽ jug blé dén kónã ko nẽ criança DEM MS próp. pai POSP algo olho comer AUX.2 'aquela criança está comendo fruta com seu pai'

(583) zug ũ ta vũ katẽ branco dem MS vir 'aquele branco está vindo'

(584) kul txá ũ ta vũ u nẽ roupa preto DEM MS bonito AUX.2 'aquela roupa preta é bonita'

(585) kózy ũ ta vũ tapel nẽ pedra DEM MS chato AUX.2 'aquela pedra é chata'

(586) ugby ũ ta vũ tag jã porco DEM MS gordo AUX.1 'aquele porco é gordo'

(587) katxol ũ ta vũ kujel jã cachorro DEM MS fome AUX.1 'aquele cachorro está magro'

(588) klãdja ũ ta vũ u nõ faca DEM MS bonito AUX.1 'aquela faca é bonita'

(589) ujol ũ ta vũ kájo jã. anta DEM MS magro AUX.1 'aquele anta está magra' 
(590) gug ũ ta vũ tag nẽ

bugio DEM MS gordo AUX.2

‘aquele buio está gordo'

(591) ugby ũ ta vũ tag jã

porco DEM MS gordo AUX.1

'aquele outro porsco está gordo'

(592) tá ũ ta zi vũ blo jé tẽ mũ

mulherDEM $3 \mathrm{~F}$ MS banhar POSP ir PERF

'aquela outra mulher foi para se banhar'

(593) kálũ ũ ta vũ goj ki kutã kũ ki ty mũ branco DEM MS água POSP cair $\mathrm{Cj}$ POSP morre PERF

'aquela outro rapaz caiu na água e morreu'

Em Laklãnõ, como ocorre em Português, nomes modificados por demonstrativos podem ser determinantes de posposições, mas diferentemente do Português, os demonstrativos Laklãnõ se mantêm unidades sintáticas independentes.

\section{Locativo}

(594) ulé tóg ki ta kutã kũ ty mũ

lagoa DEM POSP $3 \mathrm{M}$ cair $\mathrm{Cj}$ morrer PERF

'ele caiu nesta lagoa e morreu'

(595) kózy hã ta klãm ta põn bág vég mũ pedra DEM POSP $3 \mathrm{M}$ cobra grande ver PERF 'embaixo daquele pedra ele viu uma cobra grande'

(596) klẽ hã ta klãm ta kójãl pénũg mũ montanha DEM POSP $3 \mathrm{M}$ macaco atirar PERF 'embaixo daquele montanha ele atirou no macaco' 
(597) kugklũ hã ta ki zi laglu dénh ke vã

panela DEM POSP $3 \mathrm{~F}$ feijão cozinhar POSP PERF

'naquela panela ela vai cozinhar feijão'

(598) ẽn tóg ban ta dén kágglan kánãtẽ

casa DEM POSP $3 \mathrm{M}$ algo plantar andando

'em volta desta casa ele está plantando algo'

Exemplos de demonstrativos suplentes de expressões nominais em funções sintáticas distintas:

Sujeito

tóg

(599) tóg vũ blaj mũ

denon MS quebrar PERF

'este quebrou'

(600) 1. tóg tá ti katẽg vã

DEM POSP $3 \mathrm{M}$ vir ESTAT

'este está vindo de lá'

(601) tóg klãm ta nẽ

DEM embaixo $3 \mathrm{M} \quad$ AUX.2

'este está embaixo deste’

(602) tóg ki ta vũ kutã mũ

DEM POSP $3 \mathrm{M}$ MS cair PERF

'este caiu aqui'

(603) tóg vũ ko tẽ

DEM MS comer IMPERF

'este vai comer' 
(604) tóg vũ ko nẽ

denon MS trabalhar AUX.2

'este está comendo/este está comendo sentado'

(605) tóg vũ kutã tẽ

DEM MS cair IMPERF

'este vai cair'

(606) tóg kutã vã

DEM cair ESTAT

'este está caindo'

(607) tóg vũ kájo jã

DEM MS magro AUX.1

'este é magro'

(608) tóg vũ kutã mũ

DEM MS cair PERF

'este caiu'

hã ta

(609) hã ta ti tũ vã

$\begin{array}{lll}\text { DEM } & 3 \mathrm{P} \text { dele ESTAT }\end{array}$

'aquele é dele'

(610) hã ta vũ ko mũ

DEM MS comer PERF

'aquela outro comeu'

(611) hã ta vũ ko jã

DEM MS comer AUX.1

'aquele está comendo' 
(612) hã ta vũ ko tẽ

DEM MS comer IMPERF

'aquele vai comer'

(613) hã ta vũ kutã tẽ

DEM MS cair IMPERF

'aquele vai cair'

(614) hã ta vũ kutã mũ

DEM MS cair PERF

'aquele caiu'

(615) hã ta vũ kutã jã

DEM MS cair AUX.1

'aquele está caindo/aquele está caindo em pé'

$\tilde{u} t a$

(616) ũ ta vũ kutã tẽ

DEM MS cair IMPERF

'aquele outro vai cair'

(617) ũ ta vũ kutã vã

DEM MS cair ESTAT

'aquele outro está caindo'

(618) ũ ta vũ kutã mũ

DEM MS cair PERF

'aqule outro caiu'

(619) ũ ta vũ ko tẽ

DEM MS comer IMPERF

'aquele outro vai comer' 
(620) ũ ta vũ ko mũ

DEM MS comer PERF

'aquele outro comeu'

\begin{tabular}{|c|c|c|c|}
\hline (621) & ũ ta & ti & tũ \\
\hline & DEM & $3 \mathrm{P}$ & dele \\
\hline
\end{tabular}

'aquele outro é dele'

Objeto direto

(622) ũ ta bag ta mũ

DEM pegar $3 \mathrm{M}$ PERF

'aquele outro ele pegou'

(623) ũ ta zag zi mũ

DEM lavar $3 \mathrm{~F}$ PERF

'ela lavou outro'

Função oblíqua

(624) tóg ló kamũ

DEM POSP vir

'vem por aqui'

(625) tóg mõ jẽl vũ klãgnẽ nẽm mũ

DEM POSP criançaMS carne dar PERF

'para este (cachoro) a criança deu carne'

(626) hã ta ki zi kutã mũ

DEM POSP $3 \mathrm{~F}$ cair PERF

'naquele lugar ela caiu' 
(627) hã ta ló ta tẽ mũ

DEM POSP $3 \mathrm{P}$ ir PERF

'ele foi por lá/ele foi por ai'

Demonstrativos em função pronominal não se combinam com marca de gênero feminino. Esta marca sinaliza o gênero do referente apenas em sintagmas nominais que têm por núcleo um nome. E quando um nome é modificado por um demonstrativo, a marca de gênero feminino segue o demonstrativo.

(628) tá ũ ta zi vũ blo jã

mulherDEM $\quad 3 F \quad$ MS banhar AUX.1

'aquela outra mulher foi se banhar'

(629) tá ũ ta zi blé ta dén kupég mũ

mulherDEM $3 \mathrm{~F}$ POSP $3 \mathrm{M}$ algo lavar PERF

'aquela outra mulher está lavando algo com ele'

(630) tá hã ta zi vũ ẽn ban pun kánãtẽ

mulherDEM $3 \mathrm{~F} \quad \mathrm{MS}$ casa POSP varrer andando

'aquela mulher está varendo ao redor da casa'

\subsubsection{Palavras temporais}

Há, em Laklãnõ, sete palavras temporais todas formadas a partir de nomes e de demonstrativos: vãha 'agora' e vãtxỹ 'antigamente', la ũ tá 'ontem', la ũ ta tá 'antes de ontem' e kulagh $\tilde{u}$ 'amanhã', hã ta-ka, naquela vez, naquele tempo', e kól kũ 'depois'. Exemplos com palavras temporais são dados a seguir.

vãha

(631) ẽnh ji vũ vãha tavig tẽ

1 filho MS agora chegar IMPERF

'meu filho vai chegar aqui agora (ou aqui a pouco)' 
$\boldsymbol{v} \tilde{\boldsymbol{a}} \boldsymbol{t} \tilde{\boldsymbol{y}} k a$

vãtxỹ combina-se com a posposição $k a$ 'inessivo estático e singular', resultando em vãtx $\tilde{y} k a$ 'naquele tempo'. Da mesma forma o dêitico hã ta pode se combinar com a mesma posposição, hã ta, para expressar 'naquele tempo'

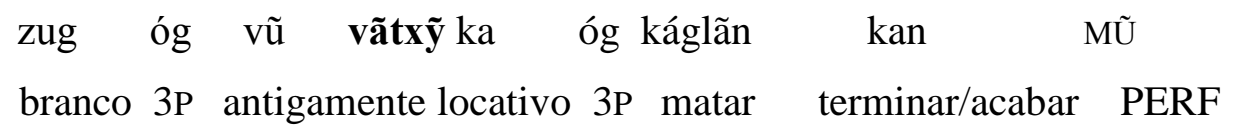
'antigamente os brancos mataram todos'

(633) vãtxỹ ka te ka gó tóg te tõ ãg tũ nẽ jó vã antigamente ESPEC POSP terra DEM ESPEC TRANS 1P seu está RETR ESTAT 'antigamente esta terra era nossa'

(634) vãtxỹ-ka jug te óg tõ gó tóg te ban jó vã antigamente pai ESPEC 3P TRANS terra este ESPEC pegar RETR ESTAT 'há muito tempo meus ancestrais adquiriram esta terra'

(635) ẽnh ja nũ vãtxỹ ka jõ blé kugklũ kághan gégke MŨ 1 ENF MS antigamente mãe POSP panela fazer (pl) HAB PERF ' antigamente eu ajudava minha vó fazer panela de barro'

\section{hã ta-ka}

(636) ãg jóklég mũ mũ hã ta-ka ti vãzol jó vã

$1 \mathrm{P}$ caçar ir ir naquele tempo 3M perder RETROP ESTAT 'naquela vez que fomos caçar ele se perdeu'

(637) zug óg jul mũ hã ta-ka ta tẽ MŨ branco 3P chegar ir naquela tempo 3M ir PERF 'naquele vez que os brancos chegaram ele foi embora' 
(638) kãggunh ty mũ hã ta-ka ta tavig MŨ

nom.masc morrer ir naquela tempo 3M chegar PERF

'naquele dia que kãggunh morreu ele chegou'

(639) jug tavig mũ hã ta-ka ta ẽnh jé klágnẽ bó katẽ MŨ pai chegar ir naquele tempo 3P 1 POSP carne trazer vir PERF

'naquela vez que meu veio ele trouxe carne para mim'

vãtxỹ pode se combinar com a partícula tave 'intensivo' para indicar um passado mais que distante.

$v \tilde{a} t x \tilde{y} \operatorname{tave\tilde {~ka}}$

(640) tó vũ vãtxỹ tavẽ ka kutã bág MŨ

chuva MS há.muito.tempo cair ADV PERF

' choveu bastante há muito tempo atrás'

A idéia de ontem é expressa pela combinação do nome la 'sol' modificado pelo dêitico $\tilde{u}>$ la $\tilde{u}$, por sua vez marcada pela posposição tá 'locativo difuso', significando 'pelo outro sol'.

\section{la $\tilde{u}$ tá}

(641) tó vũ la ũ tá kutã bág mũ chuva MS ontem cair ADV PERF

'ontem choveu bastante'

(642) jug vũ la ũ tá brasília ló tẽ mũ pai MS ontem brasília POSP ir PERF

'ontem meu pai foi para brasíli a'

(643) zug óg vũ jẽl óg mõ la ũ tá kul vin mũ branco 3PP MS criança 3P POSP ontem roupa dar PERF 'ontem os branco deram roupa para as crianças' 
(644) jug vũ lá ũ tá kóggó ban mũ pai MS ontem doente de novo PERF

'ontem meu pai ficou doente de novo'

(645) ẽnh ja nũ la ũ tá ugby bág tanh mũ 1 ENF MS ontem porco ADV matar PERF 'ontem matei um porco grande'

(646) Dil vũ la ũ tá détéj klég mũ nom. masc MS ontem palmito cortar PERF 'ontem dil cortou palmito'

la ũ ũ ta tá - 'antes de ontem'. Esta expressão é formada por la ũ $+\tilde{u}+$ ta + tá, literalmente 'por esse outro outro dia'

(647) la ũ $\tilde{\mathrm{u}}$ ta tá ta tavig mũ sol OUTRO OUTRO $3 \mathrm{M}$ POSP $3 \mathrm{M}$ chegar PERF 'antes de ontem ele chegou'

(648) la ũ ũ ta tá óg jul mũ sol OUTRO OUTRO 3M POSP 3P chegar (pl.) PERF 'antes de ontem eles chegaram'

(649) la un un ta tá zi tõ ti ve jó vã sol OUTRO OUTRO $3 \mathrm{M}$ POSP MG TRANS $3 \mathrm{M}$ ver RETR ESTAT 'antes de ontem que ela viu ele'

(650) la ũ un ta ta ta ti ve jó vã sol OUTRO OUTRO $3 \mathrm{P}$ POSP $3 \mathrm{P}$ 3P ver RETR ESTAT 'antes de ontem que ele viu ele'

(651) la ũ ù ta tá ta ty mũ sol OUTRO OUTRO $3 \mathrm{M}$ POSP $3 \mathrm{M}$ morrer PERF 
'antes de ontem que ele morreu'

kól kũ - 'depois'

(652) kól kũ nũ ló tẽ tẽ

depois $\mathrm{Cj} \quad 1 \mathrm{P} \quad$ POSP ir IMPERF

'depois eu vou entrar'

(653) kól kũ ta ló la tẽ depois $\mathrm{Cj} \quad 3 \mathrm{M} \quad$ POSP entrar IMPERF

'depois ele vai entrar lá'

(654) kól kũ nã ko tẽ

depois $\mathrm{Cj} \quad 1 \mathrm{P} \quad$ comer IMPERF

'depois iremos comer'

(655) kól kũ zi tõ ló tẽ-g ke vã

depois $\mathrm{Cj} \quad 3 \mathrm{~F} \quad$ TRANS POSP ir-NOM retr ESTAT

'depois ela vai lá'

(656) kól kũ ti tõ ti ve jó vã

$\begin{array}{lllll}\text { depois } \mathrm{Cj} & 3 \mathrm{M} & \mathrm{TRANS} & 3 \mathrm{M} & \text { ver RETR ESTAT }\end{array}$

'depois que ele viu ele'

kulag ban - 'depois de amanhã'

(657) kulag ban kũ ta tavig tẽ

$\begin{array}{lllll}\text { amanhã de novo } & \mathrm{Cj} & 3 \mathrm{M} & \text { chegar } & \text { IMPERF }\end{array}$

'depois de amanhã ele chegará'

(658) kulag ban kũ ta ló tẽ tẽ amanhã de novo $\mathrm{Cj} 3 \mathrm{M} \quad$ POSP ir IMPERF

'depois da manhã ele vai lá' 
(659) kulag ban kũ nã lanhlanh tẽ amanhã de novo $\mathrm{Cj}$ 1P trabalhar IMPERF

'depois da manhã iremos trabalhar'

(660) kulag ban kũ zi kul kágzag tẽ amanhã de novo $\mathrm{Cj} \quad 3 \mathrm{~F}$ roupa lavar IMPERF

'depois da manhã ela vai lavar roupa'

\begin{tabular}{|c|c|c|c|c|}
\hline (661) kulag & ban & $\mathrm{ku}$ & nũ & blo \\
\hline amanhã & de novo & $\mathrm{Cj}$ & 1 & banhar \\
\hline
\end{tabular}

'depois da manhã eu vou tomar banho'

\section{Partícula temporal}

Há em Laklãnõ uma única partícula temporal, ũtógli, formada originalmente do dêitico ũ, combinado com tógli, mas hoje inanalizável.

(662) zug óg vũ ũtógli jul tẽ branco 3P MS hoje chegar IMPERF 'os brancos vão chegar hoje'

\subsubsection{Palavras interrogativas}

Há duas palavras interrogativas em Laklãnõ, $\tilde{u}$ 'quem, alguém'e de 'o que'.

(663) ũ óg nũ vũ kamũ? quem 3P interr. MS vir 'quem está vindo?

(664) $\tilde{\mathrm{u}}$ nũ ki kajã?

ESPEC ind. interr. POSP chegando

'quem está chegando?' 
(665) de han ta mũ?

o.que fazer $3 \mathrm{M} \quad \mathrm{PERF}$

'o que foi que ele fez?'

(666) de kójam ta ẽn kuty te tá mũ?

o.que comprar 3M casa escuro/cheio ESPEC POSP PERF

'o que ele comprou na cidade?'

(667) de óg kléj te ki han gégke mũ?

o.que 3P pilão ESPEC POSP fazer HAB PERF

'o que eles fazem no pilão?'

Em Laklãnõ, o demonstrativo hã é base da formação das expressões temporais 'quando', 'lugar em que', 'lugar para onde', 'lugar de onde', 'com que', como mostram os seguintes exemplos:

'quando'

(668) hã ló ke ló a ji te pó mũ? interr. POSP POSP POSP 2 filho(a) ESPEC nascer PERF 'quando seu filho nasceu?'

'onde'

(669) hã ka a nũgjẽn te nẽ?

interr. POSP 2 irmão ESPEC IMPERF

'onde mora seu irmão?'

'aonde'

(670) hã ló a tẽ-g nũ vã?

interr. POSP 2 ir-NOM 1 ESTAT

'aonde você vai indo? para onde você está indo?' 
'de onde'

(671) hã tá a katẽ-g nũ vã?

interr. POSP 2 vir-NOM 1 ESTAT

'de onde você está vindo?'

(672) hã tá a jug te katẽ-g nũ vã?

interr. POSP 2 pai ESPEC vir-NOM 1 ESTAT

'de onde veio o seu pai?'

'por meio de que'

(673) hã ló ke ló mã ẽn kuty ló tẽ jé? interr. POSP PROSP POSP $2 \mathrm{P}$ casa escuro/cheio POSP ESPEC dat.2 'como você vai para a cidade?'

'como'

(674) hã like kũ mã kãj te han gégke MŨ interr. POSP $\mathrm{Cj} 2 \mathrm{P}$ balaio/cesto ESPEC fazer HAB PERF 'como você faz o cesto?'

(675) hã like kũ katxol te ty mũ? interr. POSP $\mathrm{Cj}$ cachorro ESPEC morrer PERF 'como o cachorro morreu?'

'de onde'

(676) hã tá a katẽ-g nũ vã?

interr. POSP 2 vir-NOM 1 ESTAT

'de onde você está vindo ?' 
(677) hã ló ke ló kuzó te a mõ gal te vin mũ? interr. POSP PROSP POSP velho ESPEC 2 POSP milho Espec ar PERF 'quando é que o velho te deu o milho para você?'

(678) hã ki kuzó te a mõ gal vin mũ ? interr. POSP velho ESPEC 2P POSP milho dar PERF 'a onde o velho lhe deu o milho para você?'

A palavra interrogativa $d e$, combinada com a posposição jé, expressa a razão, o porquê, a causa e a finaliade:

(679) de jé mã ẽnh jé kyl mũ?

o.que POSP 21 POSP chamar PERF

'qual a razão de você me chamar?'

(680) de jé a txul nũ vã?

o.que POSP 2 querer 1 ESTAT

'o que você quer?'

(681) de jé mã jug te jé kyl mũ? o.que POSP 2P pai ESPEC POSP chamar PERF 'porque você chamou meu pai?'

(682) de jẽ mã plãl nẽ? o.que POSP 2P chorar estar 'por que você está chorando?'

(683) de jé óg kamũ nũ vã? o.que fazer $3 \mathrm{P}$ vir $1 \quad$ ESTAT 'por que eles vieram?' 
A pergunta sobre instrumento também se faz a partir da palavra interrogativa de, mas combinando-a com a posposição tõ 'instrumentivo'

(684) de tõ ta ugby te tanh jé?
interr trans $3 \mathrm{M}$ porco ESPEC matar POSP
'com o que ele vai mattar o porco?'

$\begin{array}{lllllll}\text { (685) } & \text { de } \quad \text { tõ } & \text { nũ } & \text { mẽ } & \text { gẽg } & \text { jẽ? } \\ \text { interr trans } & 1 \quad \text { por tudo } & \text { esfregar } & \text { POSP } \\ \text { 'com oque vou passar?' } & & \end{array}$

(686) de tõ ta gó te kag jé?
interr trans 3M terra ESPEC cavar POSP
'com que ele cavou a terra?'

\subsubsection{Adjetivos}

Nesta tese, descrevemos uma classe de adjetivos para a língua Xokleng, considerando suas propriedades gramaticais. Diferentemente dos nomes, os adjetivos não funcionam como núcleo de sintagmas nominais e como núcleo de predicados nominais. Há, porém, palavras como a palavra para velho que funcionam tanto como núcleos de sintagmas nominais como funcionam como atributos de nomes.

Enquanto atributos, adjetivos seguem o núcleo do sintagma nominal, e um mesmo núcleo nominal pode ser modificado por mais de um adjetivo, como veremos em seguida. Adjetivos não funcionam como complemento de Posposições e quando são núcleos de predicados vêm necessariamente combinados com marcas aspectuais continuativas, progressivas e imperfectivas.

Segundo Dixon (1994, p.15), “em um grande número de línguas, um adjetivo tem a possibilidade de constituir um sintagma nominal inteiro, sem nenhum nome (embora o núcleo nome esteja implícito e elipsado sob certas condições discursivas)". Entretanto, em Laklãnõ adjetivos só ocorrem em função de atributo ou de núcleo de predicados estativos.

Apresentamos em seguida, exemplos de adjetivos, organizados por categorias semânticas, em função de atributo.

Exemplos de adjetivos que expressam cores 
(687) ẽn kupli

'casa branca'

(688) kul kutxug

'roupa vermelha'

(689) txãggõnh tánh

'pássaro verde/azul'

(690) mẽg txá

'onça preta'

(691) kul lul

'roupa cinza'

(692) kó zej kutxũg

flor rosa/lilás

(693) kónhka tánh

'arvore verde'

(694) gal bu tanh

'espiga de milho verde'

(695) kó tanh

'madeira verde'

(696) klẽ kágki txá

'cabelo preto'

(697) kózej kutxũg

'flor rosa/lilás' 
(698) mẽg txá

'onça preta'

(699) kul lul

'roupa cinza'

(700) txãggõnh txá

'passarinho preto'

(701) ẽnh kul kutxũg

'minha roupa rosa/lilás'

(702) kabe kutxũg

'veado pardo'

Exemplos de adjetivos que expressam dimensões:

(703) kó bág

'árvore grande'

$\begin{array}{lll}\text { (704) kó } & \text { katxin } \\ & \text { 'arvore } & \text { pequena' }\end{array}$

(705) kó zutin

arvore baixa

$\begin{array}{lll}\text { (706) kó } & \text { téj } \\ \text { 'arvore comprida' }\end{array}$

(707) ẽn bág

'casa grande'

(708) ẽn katxin 
'casa pequena'

(709) põn tõ jym ke

'cobra sinuosa'

(710) dén tapél

'superfície redonda'

(711) ulé tõdig

'lagoa profunda'

(712) ãmẽn jondjol

'caminho sinuoso'

Exemplos de adjetivos que expressam consistência e textura:

(713) gal tadaj

'milho mole'

(714) gal tól

'milho duro'

(715) kózy kózaj

'pedra áspera'

(716) kózy kódél

'pedra lisa'

(717) lõnhlõj tydyl

'areia macia'

(718) kávénh kutũ

'sangue espesso'

(719) goj zapli 
'água transparente'

Exemplos de adjetivos que expressam idade:

\section{tag - novo}

$\begin{array}{ll}\text { (720) tá } \quad \text { tag } \\ \text { 'mulher } & \text { nova' }\end{array}$

Exemplos de adjetivos que expressam valores e propensões:

(721) téj nũ jã

alto/comprido 1 AUX. 1

'eu sou alt a'

(722) ta vũ zutin jã

3P MS baixo/curto AUX.1

'ele é baixinho'

(723) kupli mã jã

branco 2 AUX.1

'você é claro'

Diferentemente dos nomes, adjetivos não funcionam como argumento, apenas como atributos e como núcleos de predicados essivos e estativos. Nesta função requerem um dos auxiliares $v \tilde{a}, n e, j \tilde{a}, n \tilde{\text { ou }} t e$, o que depende da natureza do sujeito, se classificado como deitado/comprido nõ ' 'sentado'/‘arredondado'/‘cheio' ne, 'em movimento contínuo/estendido, contínuo’ tẽe, ‘em.pé/inclinado jã , ou se é um predicado de natureza possessiva (wã).

Finalmente, observamos que, em Laklãnõ, um nome pode ser modificado por mais de um adjetivo, às vezes até cinco, como mostram os exemplos seguintes:
(724) a vãnhkágze vã
2 contente/feliz ESTAT 
'você é alegre'

(725) ti vãnhkágze vã

$3 \mathrm{M}$ contente/feliz ESTAT

'ele é alegre'

(726) zi vãnhkágze vã

3F CONTente/feliz ESTAT

'ela é alegre'

(727) ãg vãnhkágze vã

1P contente/feliz ESTAT

'nós somos alegres'

(728) mẽ a vãnhkágze vã

2P contente/feliz ESTAT

'vocês são felizes'

(729) óg vãnhkágze vã

$3 \mathrm{P}$ contente/feliz ESTAT

'eles são felizes'

(730) kózy hã ta vũ bág nẽ

pedra DEM MS grande AUX.2

'aquela pedra é grande'

(731) péhov hã ta vũ txá nẽ

$\begin{array}{llll}\text { abobora } & \text { DEM } & \text { MS maduro }\end{array}$

'aquela abóbora está madura'

(732) glun tõ tá ũ ta zi vũ tag nẽ

gato TRANS femea DEM MG MS gordo AUX.2

'aquela gata femea é gorda'

(733) dén kónã ũ ta vũ kugklé nẽ 
Algo fruta DEM MS podre AUX.2

'quela fruta está podre'

(734) goj ũ ta vũ zãkly jã

água DEM MS sujo AUX.1

'aquela outra água é suja'

(735) ẽn ũ ta vũ $u$ tavẽ jã.

casa DEM MS bonito ADV AUX.1

'aquela casa é muito bonita'

(736) jẽl hã ta vũ $u \quad$ jã

criança DEM MS bonito AUX.1

'aquela criança é bonita'

(737) kó hã ta vũ téj jã

árvore DEM MS POSP AUX.1

'aquela árvore é alta'

(738) põn hã ta vũ u nõ

cobra DEM MS bonito AUX.1

'aquela cobra é bonita'

\subsubsection{Posposições em Laklãnõ (Xokleng)}

O Laklãnõ possui um rico conjunto de Posposições, em que são fundamentais os traços +/- movimento, +/-plural, +/- distante, +/- animado, +/- localidade. A descrição de cada posposição acompanhada de exemplos é apresentada a seguir.

ban 'sem movimento e ao redor de objetos em geral'

(739) ẽn te ban kajãg vũ tẽ casa ESPEC POSP cerca MS IMPERF 
'em redor da casa tem cerca'

(740) kózy ban óg nõdẽ

pedra POSP 3P AUX.1,2P (pl.)

'eles estão ao redor da pedra (sem movimento)'

(741) zi ban óg nõdẽ

3F POSP 3P AUX. 1, 2P (pl.)

'ele estão ao redor dela (sem movimento)'

Em todos os exemplos acima o que está ao redor é algo ou alguém em situação estática, como a cerca do primeiro exemplo, que está disposta ao redor da casa, mas sem movimento.

pégjẽn 'ao redor de algo, em movimento'

Diferentemente de ban, a partícula pégjẽn requer que o referente de seu complemento esteja em movimento, em situação de dinamicidade.

(742) jẽl óg vũ ẽn pégjẽn nõdẽ criança 3P MS casa POSP AUX. 1,2 (pl.)

As crianças estão ao redor da casa (em movimento, brincando, pulando, dançando, entre outros)'

(743) le vu ẽn te pégjẽn tẽ capim MS casa ESPEC POSP IMPERF 'tem capim ao redor da casa (em movimento, crescendo e balançando pela ação do vento, mas também com distribuição desordenada)'

(744) zug óg vũ goj te pégjẽn nõdẽ branco 3P MS água ESPEC POSP AUX. 1, 2P (pl.) 'os brancos estão ao redor da água (em atividade)'

blé 'associativo.1'

Essa partícula locativa expressa associação interativa e dinâmica' 
(745) jug vũ ẽnh blé tẽ MŨ

pai MS 1 POSP ir PERF

'meu pai foi junto comigo'

(746) Ãmẽdo zi vũ óg blé katẽ

nom. fem. MG MS 3P POSP vir

'a Ãmẽdo está vindo com eles'

(747) jẽl vũ zug te blé tẽ

criança MS branco ESPEC POSP IMPERF

'a criança está indo junto com o branco'

dun 'associativo.2'

A partícula dun denota uma associação dinâmica, mas com distância temporal.

(748) ti klã óg vũ ti dun mũ MŨ

3P filho 3P MS 3P POSP ir PERF

'os filhos dele foram atrás dele'

(749) 50. zi nõ zi vũ zi dun tẽ MŨ

3F mãe MG MS 3F POSP ir PERF

'a mãe dela foi atrás dela'

Embora o primeiro e o último exemplos contenham verbos de movimento, a associação estabelecida se dá associada à distância temporal.

(750) kãggunh vũ ẽ jug dun tẽ MŨ

nom. masc. MS CORR pai POSP ir PERF

'kãggunh foi atrás do pai dele'

(751) jẽl óg vũ ẽ jug du mũ MŨ

criança 3P MS CORR pai POSP ir PERF

'as crianças foram atrás do pai dele' 
(752) ẽnh txõ ẽnh ji du tẽg vã

1 TRANS 1 filho POSP ir ESTAT

'eu estou indo atrás do meu filhos'

$d u \quad$ 'associativo 3'

A partícula $d u$ aplica-se a complementos cujos referentes são singulares e inanimados.

(753) ẽnh do vũ kó du jã

1 arco MS árvore POSP AUX.1

'minha flecha está junto à arvore'

la 'proximativo'

(754) ẽn te la ta tavig mũ

casa ESPEC POSP 3P chgar PERF

'ele chegou perto da casa'

(755) 26. ãmẽn te la ta tavi kũ nẽ caminho ESPEC POSP 3P chegar $\mathrm{Cj}$ AUX.2

'ele chegou e está próximo a estrada'

(756) 27. tá tag zi vũ ẽnh la nẽ kũ nẽ mulher nova $3 \mathrm{~F} \quad$ MS 1 POSP estar $\mathrm{Cj} \quad$ AUX.2 'uma mulher nova está próxima'

$k a \quad$ 'inessivo estático e singular'

(757) ẽnh mãg vũ ẽn ka ka nẽ 1 criação MS casa dentro POSP AUX.2 'minha criação está dentro de casa'

(758) ti ji vũ kãkénh ka ka nẽ 3M filho MS cano dentro POSP AUX.2 
'o filho dele está dentro da canoa'

jug vũ ẽn ka tá jã.

pai MS casa POSP POSP AUX.1

'meu pai está lá dentro da casa'

ki 'inessivo dinâmico e/ou plural'

Em princípio, $k i$ expressa a noção de inessivo plural, mas seu complemento pode ser um nome com referente singular, entretanto, sujeito de um evento ou processo dinâmico.

Assim, $k i$ não pode ter como complemento uma expressão nominal de referente singular e estático como 'ele está na água (parado)'

(759) jẽl tõ goj ki kutã vã

criaça TRANS água POSP cair ESTAT

'a criança que está caindo na água'

(760) 17. ulé ki zi kutâ MŨ

lagoa POSP $3 \mathrm{~F}$ cair PERF

'ela caiu na lagoa'

(761) kuzó vũ txó ki kutã MŨ

velho MS perau POSP cair PERF

'o velho caiu no perau'

klãm 'em baixo de algo ou alguém'

(762) põn vũ ẽn klãm nẽ

cobra MS casa POSP AUX.2

'há uma cobra debaixo da casa'

(763) jẽl óg vũ kó klãm nõdẽ

criança 3P MS árvore POSP AUX.1, 2P (pl.)

'as crianças estão debaixo da árvore' 
(764) katxol vũ kózy klãm nẽ

cachorro MS pedra POSP AUX.2

'cachorro está debaixo da pedra'

klẽ 'em cima de algo ou alguém'

(765) 28. txãggõnh vũ ẽn klẽ nẽ pássaro MS casa POSP AUX.2

'pássaro está em cima da casa'

(766) põn vũ kózy klẽ nẽ

cobra MS pedra POSP AUX.2

'a cobra está em cima da pedra'

(767) ugby vũ ãmẽn klẽ jã.

porco MS caminho/Estrada POSP AUX.1

'tem um porco em cima da estrada'

jy 'atrás de'

(768) mẽg te vũ kó te jy nẽ

onça ESPEC MS arvore ESPEC POSP AUX.2

'a onça está atrás da arvore'

(769) jẽl vũ ẽn te jy jã.

criança MS casa ESPEC POSP AUX.1

'a criança está atrás da casa'

(770) ujol vũ kózy te jy nẽ

anta MS pedra ESPEC POSP AUX.2

'a anta está atrás da pedra' 
jo 'por'

(771) ẽ jug jo ti nẽ vã

CORR pai POSP 3M estar ESTAT

'ele está esperando por seu pai'

(772) ẽnh txõ ẽnh ji jo jãg vã 1 TRANS 1 filho POSP estar ESTAT

'eu estou esperando pelo meu filho'

(773) jẽl tõ ẽ jug jo zãmũ nẽ vã criança TRANS CORR pai POSP esperar estar ESTAT 'a criança está esperando seu pai'

like 'similar a'

(774) a kul vũ ẽnh kul like nẽ 2P roupa MS 1P roupa POSP AUX.2 'sua roupa é parecida com a minha roupa'

(775) 32. ẽnh ji vũ ẽnh like jã 1 filho MS 1 POSP AUX.1 'meu filho é parecido comigo'

(776) 33. ti klãgdja vũ ẽnh txũ like nõ 3M faca MS 1 meu POSP AUX.2 'a faca dele é parecida com a minha'

ló 'diretivo.1'

O diretivo.1 implica um deslocamento na direção de um lugar distante.

(777) jug vũ goj ló tẽ MŨ

Pai MS água POSP ir PERF 
'meu pai foi para o rio'

(778) 35. ẽnh ji vũ Brasília ló tẽ MŨ

1 filho MS nom. lugar POSP ir PERF

'meu filho foi para Brasília'

to 'diretivo.2'

O diretivo.2 corresponde a um deslocamento em direção um lugar próximo.

(779) jug vũ gal to tẽ MŨ

pai MS milho POSP ir PERF

'meu pai foi no milho'

(780) Kãggunh vũ ẽ ji to katẽ

nom. masc. MS CORR filho POSP vir

'Kãggunh veio no filho dele'

(781) jẽl óg vũ ẽ jug to kamũ MŨ

criança 3P MS CORR pai POSP vir PERF

'as crianças vieram no seu pai'

jé 'dativo dinâmico'

(782) zug vũ jug jé kul bó katẽ MŨ

branco MS pai POSP roupa pegar vir PERF

'o branco trouxe roupa para meu pai'

(783) ti ji vũ ẽ jug jé gal gég tẽ MŨ

3P filho MS CORR pai POSP milho pega(pl.) ir PERF

'o filho dele trouxe milho para seu pai'

(784) ẽnh ji jé nũ laglu bó katẽ

1 filho POSP 1 feijão pegar vir

'eu trouxe milho para meu filho' 
(785) de mã kuzó jébó katẽ?

Interr 2 velho POSP carrgar vir

'o que você trouxe para o velho?

mõ 'dativo estático'

(786) jug vũ ẽ mãg mõ péhov nẽm MŨ

pai MS CORR criação POSP abobora dar PERF

'meu pai deu abóbora para sua criação'

(787) ta vũ ẽ jug mõ laglu blé gal vin MŨ

3M MS CORR pai POSP feijão POSP milho dar PERF

'ele deu feijão com milho para seu pai'

(788) ẽnh ja ẽ txõ vãnh mõ kul ban vã

1 ENF CORR TRANS próp POSP roupa pegar ESTAT

'eu mesmo peguei essa roupa pra mim'

tá 'locativo difuso'

Esta partícula locativa engloba em seu significado o de locativo difuso e de ablativo, como mostram os seguintes exemplos:

tà 'locativo difuso/ablativo'

(789) goj jógtanh tá óg ãgglag nõdẽ água outro lado POSP 3PP festejar AUX.1,2P (pl.)

'pelo rio eles estão festejando', 'do outro lado do rio eles estão festejando'

(790) Kãggunh vũ kute te tá jã

nom. masc MS mato ESPEC POSP aux.1

'kãggunh está lá no mato' 
$\begin{array}{lllll}\text { (791) ẽn } & \text { kuty tá } & \text { ti } & \text { katẽg } & \text { vã } \\ \text { casa } & \text { escuro POSP } & 3 \mathrm{P} & \text { vir } & \text { ESTAT } \\ \text { 'ele veio da cidade' } & & & \end{array}$

(792) jug tõ brasília tá katẽg vã

pai trans nom.lugar POSP vir ESTAT

'meu pai está vindo de Brasília'

(793) zug óg vũ goj tá kaMŨ

brancos 3P MS água POSP vir

'os brancos estão vindo da água'

(794) ẽn ki nũ kutãdẽ MŨ

casa POSP 1P sair PERF

'eu saí de casa'

$\begin{array}{llllllll}\text { (795) } & \text { jõ } & \text { zi } & \text { vu } & \text { goj } & \text { ka } & \text { kutãdẽ } & \text { mũ } \\ \text { mãe } & \text { MG } & \text { MS } & \text { agua } & \text { POSP } & \text { sair } & \text { PERF } \\ \text { 'minha mãe saiu da água' } & & & \end{array}$

(796) kute tá nã kapó MŨ

mato POSP 1P sair(pl.) PERF

'nós saímos do mato'

tõ 'translativo'.

A semântica da posposição tõ se aproxima do morfema translativo do Russo. Engloba os significados de atributivo, translativo e instrumentivo, como mostram os seguintes exemplos: 
'instrumentivo'

(797) de tõ mã kó te gõn jé?

Interr TRANS 2 árvore ESPEC derrubar POSP

'com que você vai derrubar a árvore?

(798) de tõ nũ kózy te pum jé?

Interr TRANS 1 pedra espec partir POSP

'com que vou partir o pão?'

O complemento sintático de uma posposição pode ser omitido quando constituir informação velha. Nesse caso são marcadas pelo prefixo relacional - $\emptyset$. Exemplos desse uso de Posposições são os seguintes:

ban 'sem movimento e ao redor de objetos em geral'

(799) Ø-ban kajãg gũ tẽ

R-POSPcerca $\mathrm{Cj}$ IMPERF

'tem cerca/está cercado'

(800) Ø-ban óg nõdẽ

R-POSP 3P AUX.1,2P(pl.)

'eles estão ao redor'

pégjẽn 'ao redor de algo, em movimento’

(801) jẽl óg vũ $\quad$-pégjẽn nõdẽ

criança3P MS R-POSP AUX.1,2P(pl.)

'as crianças estão ao redor' 
jy 'atrás de'

$\begin{array}{llllll}\text { (802) mẽg te } & \text { vũ } & \text { te } & \emptyset \text {-jy nẽ } & \\ \text { onça ESPEC } & \text { MS } & \text { ESPEC } & \text { R-POSP } & \text { AUX.2 } \\ \text { 'a onça está atrás' } & & & \end{array}$

(803) jẽl vũ $\quad$ v-jy $\quad$ jã

criança MS R-POSP AUX.1

'a criança está atrás ‘

$\mathrm{ka}$ 'inessivo'

(804) ẽnh mãg vũ $\emptyset$-ka $\quad$ ka nẽ

1 criação MS R-dentro POSP AUX.2

'minha criação está dentro'

(805) ti ji vũ $\mathrm{ka} \quad \emptyset$-ka nẽ

$3 \mathrm{M}$ filho MS R-dentro POSP AUX.2

'o filho dele está dentro'

$k i$ 'inessivo dinâmico'

(806) jẽl tõ $\quad$-ki kutã vã

criançagen R-POSP cair ESTAT

'é a criança que está caindo na'

(807) $\emptyset$-ki zi kutã mũ

R-POSP 3F cair PERF

'ela caiu na'

klãm 'em baixo de algo de ou alguém' 


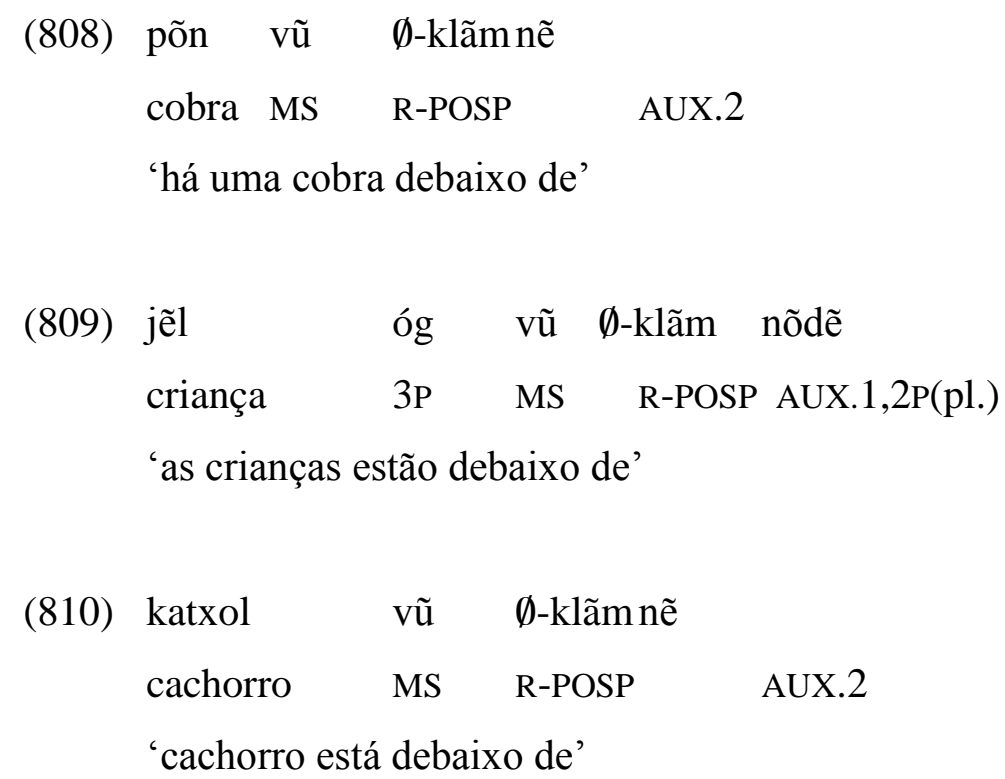

(813) zi nõ zi vũ $\emptyset$-dun tẽ mũ 3F mãe MG MS R-POSP ir PERF 'a mãe dela foi atrás'

$d u \quad$ 'associativo.3'

(814) kãggunh vũ $\emptyset$-du tẽ mũ nom masc MS R-POSP ir PERF

'kãggunh foi atraz de' 
(815) jẽl óg vũ $\emptyset$-du mũ mũ criança3PP MS R-POSP ir PERF

'as crianças foram atraz de'

la 'próximativo'

(816) la ta tavig mũ

R-POSP 3P chegar PERF

'ele chegou perto'

(817) la ta tavi kũ nẽ

R-POSP 3M chegar $\mathrm{Cj}$ AUX.

'ele chegou e está próximo de'

Klẽ 'em cima de algo ou alguém'

(818) txãggõnh vũ klẽ nẽ $\begin{array}{llll}\text { pássaro } & \text { MS } & \text { R-POSP } & \text { AUX.2 }\end{array}$

'pássaro está em cima de'

(819) põn vũ klẽ nẽ

$\begin{array}{lll}\text { cobra } & \text { MS } & \text { R-POSP }\end{array}$

'a cobra está em cima de'

like 'similar a'

(820) a kul vũ like nẽ

2 roupa MS R-POSP AUX.2

'sua roupa é parecida com'

ló 'diretivo.1' 
(821) jug vũ goj ló tẽ mũ

pai MS rio R-POSP ir PERF

'meu pai foi para o rio'

(822) ẽnh ji vũ ló tẽ mũ

1 filho MS R-POSP ir PERF

'meu filho foi para'

to 'diretivo.2'

(823) jug vũ to tẽ mũ

pai MS R-POSP ir PERF

'meu foi buscar'

(824) zug vũ jé kul bó katẽ mũ

branco MS R-POSProupa pegar vir PERF

'o branco trouxe roupa para'

$m \tilde{~} \quad$ 'dativo estático'

(825) jug vũ mõ péhov nẽm mũ

pai MS R-POSP abobora dar PERF

'meu pai deu abobora para'

tá 'locativo difuso’

(826) jógtanh tá óg ãgglag nõdẽ outro lado R-POSP $3 \mathrm{P} \quad$ festejar $\quad$ AUX.1,2P(pl)

'pelo outro lado eles estão festejando'

(827) Kãggunh vũ tá jã

nom masc MS R-POSP AUX.1

'Kãggunh está lá no mato' 


\section{Mais sobre o dativo dinâmicojé}

A Posposição jé ocorre nas perguntas com de 'o que' na função de objeto direto.

(828) de ko mã jé?

Interr comer 2 POSP

'o que você quer comer?'

O esquema da sentença em 1 e de todas as sentenças interrogativas com de na função de objeto direto é [[de Vt] [S jé]]. Outros exemplos são:

(829) de han mã jé?

interr. fazer 2 POSP

'o que você quer fazer?'

(830) de kojam mã jé?

interr. comprar 2 POSP

'o que você vai comprar?'

(831) de mã ẽnh jõ nẽm jé?

interr $2 \quad 1 \quad$ POSP dar POSP

'o que você trouxe para mim?'

(832) de han zi jé?

interr fazer $3 \mathrm{~F} \quad$ POSP

o que ela vai fazer?

(833) de tõ mã kó te gõn jé?

interr TRANS 2 árvore ESPEC derrubar POSP

'com que você vai derrubar a árvore?'

(834) de tõ nũ kózy te pum jé?

Interr TRANS 1 pedra ESPEC partir POSP

'com que vou partir o pão?' 
Sentenças interrogativas com o objeto direto expresso também têm a mesma estrutura.
(835) do ũ kághan jé?
flecha outro fazer (pl.) 2 POSP
'você vai fazer algumas flechas?'
(836) de tõ nũ kózy te pum jé?
interr TRANS 1 pedra espec partir POSP
com que vou partir o pão?

As posposições do Laklãnõ mostram como a cultura Laklãnõ concebe a localização dos seres no espaço - dinâmico/estático, singular/plural/, animado/inanimado, embrenhante/não embrenhante.

\subsubsection{Interjeições em Laklãnõ/Xokleng}

As interjeições são expressões de sentimentos, estados emotivos ou físicos dos falantes. Em Laklãnõ identificamos as seguintes interjeições:

$a ́$ 'expressão de dor'

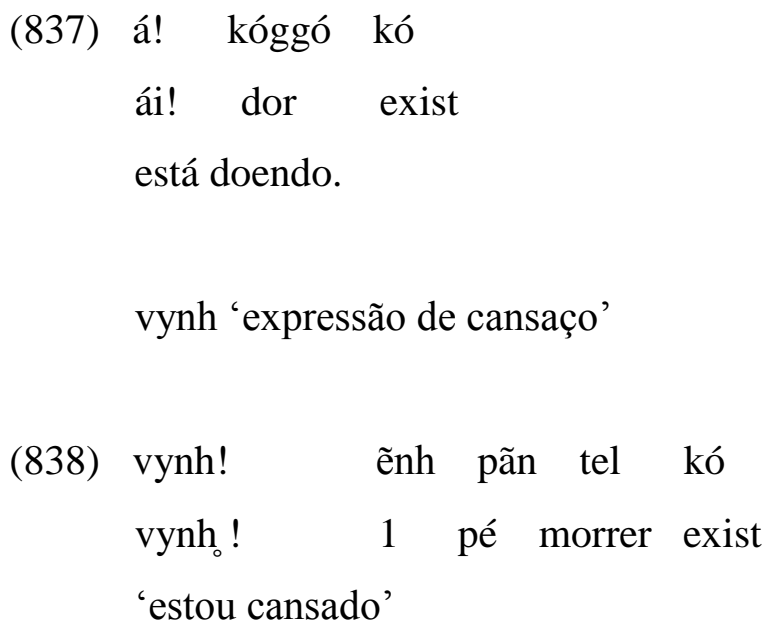


(839) janh janh! hãli ti tõ ke nũ vã? susto 3M TRANS PROSP 1 ESTAT

'o que está acontecendo com ele?

unh 'Expressão de impotência' 
(840) unh!

ẽnh kónã ki kutyg tẽ MŨ

sensação.de.impotência 1 olho POSP escurecer ir PERF

'escureceu minha vista'

(841) unh!

pénh ke nũ MŨ

‘éxprssão.de.cansaço arcar POSP 1 PERF

'estou cansado/ estou arcado'

vynh! 'expressão de desconhecimento com inquietude'

(842) vynh! hãli nũ ke jé?

desconhecimento 1 POSP POSP?

'o que vou fazer?'

unh! 'surpresa com susto'

(843) unh! de nũ vã?

desconhecimento INTERR 1 ESTAT

'o que é isso?

txé! 'expressão de curiosidde'

(844) txé! $\tilde{u}$ nũ vã?

surpresa QUEM 1 ESTAT?

'quem é?'

henh! 'expressão de surpresa assustadora'

(845) henh ke! de pivé?

supresa assustadora o.que será

'o que será?'

hólé! 'expressão de respeito' 
(846) Kãggunh vũ tõ vãgdjó hólé jã.

nom.mas. MS TRANS chefe/autoridade Express. AUX.1

'Kãggunh é o chefe/ Kãggunh é uma autoridade'

Como revelam os exemplos acima, as interjeições ocupam o primeiro lugar na sentença.

\subsubsection{Ideofones em Laklãnõ/Xokleng}

Há em Laklãnõ uma classe de palavras constituída de elementos que associam ideias a sons que as simbolizam. São os ideofones, que em Laklãnõ simbolizam os sons associados a processos e eventos, como os sons produzidos por animais, sons produzidos por fenômenos da natureza, entre outros. Reunimos aqui alguns ideofones que ilustram a classe.

Os ideofones em Laklãnõ ocorrem preferencialmente antes dos verbos núcleos das orações.

(847) tó togtov vũ tẽ jã.

chuva express. MS ir AUX.1

'está trovejando'

(848) txãggõnh te vũ hooo ke tẽ MŨ

pássaro ESPEC MS ideo.som de passarinho PROSP ir PERF

'o passarinho foi fazendo hooo'

(849) juggug te mã mõ hooo ke katẽ

pai ESPEC 2 POSP imitação PROSP vir

'o gavião vinha fazendo hooo'

(850) mẽg vũ gwin gwin ke MŨ

onça MS ideo.rosnar.de.onça PROSP PERF 
'a onça fez gwin gwuin'

(851) mẽg te mã mõ gwa gwa ke katẽ onça ESPEC ouvir POSP ideof.rosar.de.onça PROSP vir 'a onça vinha fazendo gwa, gwa'

(852) ujol vũ mã mõ ynh, ynh ke tẽ jã anta MS ouvir POSP ideof.som.de anta PROSP ir AUX.1 'a anta estava gritando fazendo ynh ynh'

(853) põn vũ mã mõ lululu ke nõ cobra MS ouvir POSP ideof.som de cobra PROSP AUX.3 'a cobra estava fazendo lululu'

(854) tó kutã te mã mõ dag dag ke tẽ jã. chuva cair ESPEC ouvir POSP ideo.do.cair.de.chuva PROSP ir AUX.1 'o cair da chuva está fazendo dag dag'

(855) mã mõ ta lanh ge katẽ ouvir POSP $3 \mathrm{M}$ ideof PROSP vir 'ele vinha fazendo lanh'

(856) ti zãnkó te klyg klyg ge MŨ 3P colar ESPEC ideof.de som.de.colar PROSP PERF 'o colar dele fez klyg klyg'

(857) mã mõ dén ũ vũ gwé gwé ke katẽ ouvir POSP algo OUTRO MS ideo.de.som PROSP vir 'alguma coisa vinha fazendo gwé gw'.

$$
\begin{aligned}
& \text { ug kale te mã mõ klõg } \quad \text { ge tẽ jã } \\
& \text { porco do mato descer ESPEC ouvir POSP ideof.de.som } \\
& \text { 'orOSP ir }
\end{aligned}
$$


$(859)$

kãgkénh te mã $\emptyset$ - mõ klõg ge katéle

canoa ESPEC ouvir R-POSP ideof.de.som.de.caanoa PROSP descer

'a canoa vinha descendo fazendo klõg'

(860) txe te mã $\emptyset$-mõ txég ke tẽ MŨ

quati ESPEC ouvir R-POSP ideof.de som.de quati PROSP ir PERF

'o quati foi fazendo txég'

(861) Pazi vũ kó klẽ tẽ tẽ tẽ me mã mõ jã

nom. masc MS árvore encima ideof.de.som.de pazi PROSP ouvir POSP AUX.1

'o Pazi estava fazendo te tẽ tẽ encima da árvore'

\subsubsection{Verbos em Laklãnõ/Xokleng}

Os verbos distinguem-se das demais classes de palavras por exprimirem processos, por não constituírem núcleo de sintagma nominal, como os nomes, e por não funcionarem como atributos de nomes. Constituem as únicas classes de palavras que podem se combinar com os dois conjuntos de formas pronominais, diferentemente dos nomes e das Posposições, que se combinam exclusivamente com pronomes da série 2.

Há verbos transitivos e verbos intransitivos, os primeiros pedem um objeto direto e os segundos não pedem objeto direto.

Uma característica dos verbos do Laklãnõ é a de distinguir formas singulares e plurais de acordo com o número do sujeito ou agente, sendo o verbo intransitivo, e de acordo o número do paciente, caso o verbo seja transitivo.

Há, porém, uma distinção que julgamos ser necessária de explicar, antes de ilustrarmos as formas singulares e plurais dos temas verbais. Trata-se da distinção entre verbos intransitivos que contribuem com noções aspectuais e verbos intransitivos que não contribuem com noções aspectuais nas predicações. Os verbos que contribuem com noções aspectuais são os verbos posicionais e de movimento. Os posicionais marcam a posição e/ou a forma física do sujeito, quando o predicado é intransitivo e do objeto quando o predicado é transitivo. 
Os verbos posicionais funcionam como classificadores de seus argumentos obedecendo a um alinhamento absolutivo.

Apresentados no quadro seguinte, os verbos posicionais com suas formas singulares e plurais:

Quadro 8 - verbos posicionais com suas formas singulares e plurais

\begin{tabular}{|l|l|l|l|}
\hline & Posição & Singular & Plural \\
\hline Verbos Posicionais & estar sentado & nẽ & jãgnẽ \\
\hline & estar deitado & nõ & jãgnõ \\
\hline & estar pendurado & txó & jãgdjó \\
\hline & estar em posição indefinida & nĩ & nỹ \\
\hline & $\begin{array}{l}\text { estar em posição indefinida, mas } \\
\text { espalhado }\end{array}$ & & nõ \\
\hline & estar em pé & jã & kójã \\
\hline
\end{tabular}

É importante considerar que as formas de plural dos verbos 'estar sentado', 'estar deitado' e 'estar pendurado' possuem o formativo jãg.

Outro fato interessante é o de que o verbo 'estar em posição indefinida', distingue duas formas de plural. Uma delas expressa um simples plural, a outra um plural complexo, pois quem está em posição indefinida, está também espalhado. E isso naturalmente só pode ocorrer no plural. A alternância das formas do verbo 'estar em forma definida reside apenas em contraste vocálico.

O sistema classificatório que se manifesta por meio de verbos posicionais é complexo, classifica os animais e os objetos de acordo com a experiência cognitiva dos seus respectivos referentes, mas quanto aos seres humanos essa classificação éstá relacionada à posição atual do referente do sujeito, por exemplo. Mas quando se trata de certas qualidades e processos, a clasificação também depende da experiência Laklãnõ. Exemplos de verbos posicionais abundam nesta tese e uma descrição específica desse fenômeno encontra-se em preparação por Nanblá e Cabral.

Um outro fato a ser observado são as formas dos verbos 'ir', 'vir', 'aproximar-se' e ‘entrar'. O verbo 'ir' tem as fomas tẽ para o singular e mũ para o plural. Já o verbo vir é formado da combinação de um primitivo $k a$ com tẽ para o singular, katẽ , e mũ para o plrual, kamũ

\begin{tabular}{|l|l|l|l|}
\hline & ir & tẽ & mũ \\
\hline & vir & katẽ & kamũ \\
\hline
\end{tabular}


Outros verbos têm etimologicamente o formativo ka, como 'aproximar-se' e entrar.

\begin{tabular}{|l|l|l|l|}
\hline & aproximar-se & katã & kajã \\
\hline & entrar (genérico) & ki la & kige \\
\hline $\begin{array}{l}\text { entrar em direção a algo ou } \\
\text { alguém oposta ao falante }\end{array}$ & ló la & kãge \\
\hline entrar em direção ao falante & ló kala & kãge \\
\hline
\end{tabular}

O verbo la combina-se com as Posposições ló, ki e ka, para formas de 'entrar' em que a direção é marcada, uma indicando que o entrar vai na direção do centro dêitico, o falante, ló kola, e outra que o entrar é em direção oposta ao centro dêitico ló la.

O verbo 'entrar', por exemplo, tem três formas singular e plural, uma delas corrresponde a entrar na direção oposta ao centro dêitico que é o falante; já a outra forma, com $k a$ significa entrar em algo em que se encontra o falante e na direção do falante.

Há um conjunto de verbos transitivos e um conjunto de intransitivos que formam seu plural adicionando à base verbal singular o formativo kág:

Quadro 9 - verbos transitivos e um conjunto de intransitivos

\begin{tabular}{|c|c|c|}
\hline \multirow{2}{*}{} & \multicolumn{2}{|c|}{ raiz } \\
\cline { 2 - 3 } & singular & plural \\
\hline cozinhar & dej, dénh & kágdej \\
\hline comprar & kójav, kójam & kágdjav, kágdjam \\
\hline terminar & kól, kan & kágkól \\
\hline plantar & klél, klan & kágklél \\
\hline fazer & hal, han & kágtxan \\
\hline pisar & txal, txan & kágza, kágzag \\
\hline lavar S. & za, zag & káplag \\
\hline morder.S & pló, pla, plag & kágtxe, kágtxég \\
\hline prender & txe, txég & kágzy \\
\hline trançar & zy & \\
\hline
\end{tabular}




\begin{tabular}{|c|c|c|}
\hline Verbos intransitivos & & \\
\hline boiar & dal, dan & kágdal, kágdan \\
\hline morrer & tel & kágtel \\
\hline sarar & lẽl & káglẽ \\
\hline
\end{tabular}

Outros verbos formam seu plural acrescentando à base o morfema mẽ:

\begin{tabular}{|l|l|l|}
\hline pendurar & txó, txag & $\begin{array}{l}\text { mẽ zãgdján, zãgdjó, } \\
\text { zágdjág }\end{array}$ \\
\hline misturar & zãjó, zãja & mẽ zãgdjó \\
\hline roçar & kule & mẽ kulé, kulég \\
\hline enterrar & de & mẽ kágde, dég \\
\hline peneirar & gle, glég & mẽ glé \\
\hline debulhar & ble, blég & mẽ blé \\
\hline colher & kle, klég & mẽ klé \\
\hline perguntar & zévãnkle, zévãnklé & mẽ zévãnkle \\
\hline ver.S & ve, vég & mẽ vé, mẽ ve \\
\hline ralar & ze, zég & mẽ zé \\
\hline por em pé & zãg & mẽ kógzãg \\
\hline torcer & kunhpã, kunhpãl & mẽ kunhpãn, kunhpãg \\
\hline amarrar & tugzẽn, tugzẽl & mẽ tugzẽn, tugzẽ \\
\hline enrolar cabelo & glẽ, glẽg & mẽ glẽn \\
\hline moquear & jagtxun, jagtxul & mẽ jagtxul, jagtxun \\
\hline juntar (grãos) & zaklun, zãklul & mẽ zagklun \\
\hline destruir & nẽkukén, nẽkukel, nẽkukég & mẽ nẽgkukel, nẽkugkég \\
\hline raspar & pankén, pankel & mẽ pankel, pãnkég \\
\hline dividir no meio & kupó, kupag & mẽ kupa, kupó \\
\hline descascar & kágza, kágzól & mẽ kágzan, kágzag \\
\hline arrancar S. & nũ, nũnh & mẽ nũ, nũg \\
\hline limpar & kágkũ, kágkunh, gól, ba, ban, bag & mẽ kágkũ, kágkũg gég \\
\hline rir & dy & mẽ dy, dyg \\
\hline rasgar & zãjól, zãnẽjól & mẽ zãnẽgdja, zãnẽgdjól \\
\hline segurar S. & ge \\
\hline segurar P. & mẽ & \\
\hline
\end{tabular}




\begin{tabular}{|l|l|l|}
\hline torrar & tutol, tutun & mẽ tutun \\
\hline contar história & kabel, kabén & mẽ kabel \\
\hline varrer & plul, plun & mẽ plun \\
\hline afastar-se & láló & mẽ láló \\
\hline
\end{tabular}

Outros verbos:

\begin{tabular}{|l|l|l|}
\hline arrebentar & tónh & tágtónh \\
\hline apagar & djyl & txyndjyl \\
\hline furar & lum & luglum \\
\hline estourar & tum & tugtum \\
\hline dormir & nũl & jãgnũl \\
\hline quebrar ovo, osso & gam & kugam \\
\hline queimar & pũl & kápũl \\
\hline alisar & kulynh & kuglynh \\
\hline comer & ko, ku & ko \\
\hline dizer & tan & kabén \\
\hline bater & lãn & lãg \\
\hline ensinar & jópalag & jógpalag \\
\hline roubar & péju & pigju \\
\hline
\end{tabular}

Verbo transitivos e intransitivos podem ser causativizados pelo morfema causativo g. O alomorfe $-g$ ocorre em temas terminados por vogal. Quando segue outras consoantes funde-se com estas, prevalecendo a nasalidade do morfema causativo e o ponto de articulação da consoante precedente. Assim, temas terminados em vogal mudam para $m$ quando causativisados, temas terminados em $l$ mudam para $n$. E quando o tema termina em consoante nasal, prevalece o ponto de articulação desta. Finalmente, temas terminados em $j$, quando causativizados mudam para $n h$.

$$
\operatorname{vogal}+\mathrm{g}
$$

\begin{tabular}{|l|l|l|l|l|}
\hline glossa & $\begin{array}{l}\text { forma } \\
\text { singular }\end{array}$ & f.sing.causativisada & forma plural & $\begin{array}{l}\text { forma plural } \\
\text { causativizada }\end{array}$ \\
\hline dividir & kaly & kaly-g & kalygly & kalygly-g \\
\hline
\end{tabular}




\begin{tabular}{|l|l|l|l|l|}
\hline embrulhar & pa & pa-g & kápa & kapa-g \\
\hline acertar & zãnã & zãnã-g & zãnã & zãnã-g \\
\hline agarrar & kagmẽ & kagmẽ-g & kugmẽ & kugmẽ-g \\
\hline
\end{tabular}

$\mathrm{v}>\mathrm{m}$

\begin{tabular}{|l|l|l|l|l|}
\hline estourar & tov & tum & tugtov & tugtum \\
\hline cortar & kyv & kym & kykyv, & kykym \\
\hline dar & nẽv & nẽm & vin & vin \\
\hline
\end{tabular}

$1>n$

\begin{tabular}{|l|l|l|l|l|}
\hline derrubar & gõl & gõn & gõngõl & gõngõn \\
\hline abrir & blil & blin & blinblil & blinblin \\
\hline jogar fora & zol & zun & lẽ & lẽnh \\
\hline
\end{tabular}

$\mathrm{j}>\mathrm{nh}$

\begin{tabular}{|l|l|l|l|l|}
\hline quebrar & bláj & blónh & blánhbláj & blánhblónh \\
\hline
\end{tabular}

teminam em $\mathrm{m}$

\begin{tabular}{|l|l|l|l|l|}
\hline furar & lum & luglum & lum & luglum \\
\hline estourar & tum & tugtum & tum & tugtum \\
\hline furar & lum & luglum & lum & luglum \\
\hline
\end{tabular}

Há um conjunto de verbos que se comporta de forma diferente. Terminam em vogal, mas sua forma causativizada recebe um $n$ e não um $g$ esperado. Estes verbos possuem uma forma plural terminada por $g$, mas a forma causativizada apresenta $n$. Exemplos desses verbos são os seguintes:

\begin{tabular}{|l|l|l|l|l|}
\hline cavar & ka & kan & mẽ kag & mẽ kan \\
\hline festejar & ãgla & ãglan & mẽ ãgglan & mẽ ãgglag \\
\hline beber & kagkla & kágklan & mẽ kagkló & mẽ kagklag \\
\hline
\end{tabular}




$\mathrm{za}$

za

zan

mẽ za

mẽ zag

\subsubsection{Nominalizações}

Verbos transitivos e intransitivos combinam-se com o sufixo -jo " nominalizador de circunstância para formar nomes de instrumentos, de lugares, de realização de eventos e processos, e de resultados de ação e de processos.

\section{Instrumento}

kan 'cavar' + -jo 'nom de circunstância' = kanjo 'cavador'

plun 'vassoura'+ -jo 'nom de circunstância'= plunjo 'limpador'

gala ze 'milho ralar'+ -jo $=$ 'ralador de milho'

lugar

blo 'banhar' + -jo = blojo 'lugar de banhar'

Resultado de uma ação ou processo

txãggõnh káglan 'passarinho matar' + -jo = matança de passarinho'

\subsubsection{Nomes de ação}

Temas verbais combindos com o nominalizador de ação $-\mathrm{g}$, -n, seguindo vogal e $-\emptyset$ seguindo consoante, resultam em nomes de ação frequentes em construções no aspecto continuativo e em outras situações.

(862) vãtxỹ-ka jug te óg tõ gó tóg te ba-n jó vã antigamente pai ESPEC 3P TRANS terra este ESPEC pegar-NOM RETR ESTAT 'há muito tempo, meus ancestrais adquiriram esta terra'

(863) ẽnh ja nũ vãtxỹ ka jõ blé kugklũ kághan gég ke MŨ 1 ENF MS antigamente mãe POSP panela fazer (pl) habitual PERF 'antigamente eu ajudava minha vó a fazer panela de barro' 
(864) ãg jóklég mũ mũ hã ta ka ti vãzol jó vã

1P caçar ir ir naquele tempo $3 \mathrm{M}$ perder RETR ESTAT 'naquela vez que fomos caçar ele se perdeu'

(865) détéj to ti tẽ-g ke vã palmito POSP $3 \mathrm{M}$ ir-NOM PROSP ESTAT 'ele vai buscar palmito' 


\section{CAPÍTULO 4 - PREDICADOS EM LAKLÃNÕ/XOKLENG}

\section{PRELIMINARES}

Em Laklãnõ há dois tipos principais de predicados, os de natureza nominal e os de natureza verbal. Essa distinção está relacionada ao típo de núcleo, se nome, adjetivo ou verbo, mas também ao aspecto ou relação de dependência entre orações, à negação, entre outros. Neste capítulo descrevemos os tipos básicos de predicados nominais e verbais.

\subsection{PREDICADOS NOMINAIS}

Os predicados nominais são dos seguintes tipos: apresentativos, possessivos, essivos, existenciais e estativos. Predicados nominais apresentativos, possessivos, essivos inclusivos e atributivos, e existenciais têm por núcleo um nome, e os estativos têm por núcleo um adjetivo.

\subsubsection{Predicados apresentativos}

(866) ẽnh ẽn vã

1 casa ESTAT

'é minha casa'

(867) tóg te ẽnh ji vã

DEM ESPEC 1 filho ESTAT

'este é meu filho'

(868) kagkénh hã ta ẽnh txũ vã

canoa DEM 1 TRANS ESTAT

'aquela é minha canoa' 
(869) ẽnh jópõ vã

1 roça ESTAT

'é minha roça'

(870) kugklũ te zi tũ vã

panela ESPEC 3F dela ESTAT

'é panela dela'

Esses predicados nominais servem para apresentar nomes no discurso, por isso alguns os chamam de 'apresentativos'.

\subsubsection{Predicados possessivos}

Há um outro tipo de predicado nominal que chamamos possessivos, mas na realidade, são construções em que o sujeito é uma costrução possessiva, marcada por vũu, que focaliza constituintes sobre os quais tratam as predicações. Nesta tese chamaremos de marca de sujeito (MS), mas pretende-se aprimorá-la futuramente.

(871) ẽnh ẽn vũ jã.

1 casa MS AUX.1

'eu tenho casa'

(872) ẽnh pãn pa vã

1 pé enrrolado/coberto ESTAT

'é meu sapato sapato'

Um outro tipo de predicado de natureza nominal são os essivos inclusivos que incluem o sujeito em uma classe. O sintagma nominal que equivale ao sujeito vem marcado pela posposição tõ 'translativo'.

$\begin{array}{lllll}\text { (873) } & \text { ti } & \text { tõ } & \text { pa'i } & \text { vã } \\ & 3 \mathrm{M} & \text { TRANS } & \text { chefe/autoridade } & \text { ESTAT }\end{array}$ 
'ele é cacique'

(874) ẽnh txõ kujá vã

1 TRANS pajé ESTAT

'eu sou pajé'

Predicados existenciais têm por núcleo nomes como 'frio' e 'quentura'. O que em línguas como o Português seria um sujeito, em Laklãnõ é um dativo.

(875) ẽnh jõ ta laglẽl tẽ

1 POSP 3P calor/sol IMPERF

'há calor para mim'

(876) ẽnh jõ ta kutxó tẽ

1 POSP 3P frio IMPERF

'é frio para mim'

Predicados essivos atributivos têm como núcleo um adjetivo:

(877) téj nũ jã.

alto/comprido $1 \quad$ AUX.1

'eu sou alto'

(878) ta vũ zutin jã.

3M MS baixo/curto AUX.1

'ele é baixinho'

(879) kupli mã jã

branco 2 AUX.1

'você é claro'

(880) ãmẽdo zi vũ kuzó jã

nom. fem. MG MS velho AUX.1

'ãmẽdo é velha' 
(881) tá tag zi vũ tag jã

mulher nova MG MS gorda AUX.1

'mulher nova ela é gorda'

(882) tá tag zi vũ zutin jã

mulher nova MG MS baixa AUX.1

'a mulher nova ela é baixinha'

(883) ẽnh ja nũ téj jã

1 ENF 1 alto AUX.1

'eu sou alto ou eu tenho altura'

(884) a ha mã téj jã.

2 ENF 2 alto AUX.1

'você mesmo é alto'

(885) ta vũ téj jã.

3M MS alto AUX.1

'ele é alto'

(886) zi vũ téj jã.

3F MS alto AUX.1

'Pela é alta'

(887) ãg ha nã téj nõdẽ

1P ENF 1P alto AUX.1

'nós mesmos somos altos'

(888) mẽ a ha mã téj nõdẽ

2P ENF 2 alto AUX.1,2P

'vocês mesmos são altos' 
(889) óg vũ téj nõdẽ

3P MS alto AUX.1,2P

'eles são altos'

\subsection{PREDICADOS ESTATIVOS}

Predicados estativos denotam estado de existência relativo ao sujeito. O sujeito é marcado por $v \tilde{u}$, se terceira pessoa, e a predicação vem marcada por um auxiliar: tẽ'imperfectivo', ou um verbo posicional.

(890) kózej vũ ẽn te ban kabág tẽ

flor MS casa ESPEC POSP ADV IMPERF

'as flores estão ao redor da casa'

(891) kute vũ ẽn te ban tẽ mato MS casa ESPEC POSP IMPERF

'o mato esta ao redor da casa'

(892) jug vũ kãgkénh ka nẽ

pai MS canoa POSP AUX.2

'meu pai está dentro da canoa'

(893) urby te vũ ulé ka nẽ

porco ESPEC MS lagoa/banhado POSP AUX.2

'o porco está na lagoa'

(894) ẽnh ji vũ zãnka ka jã.

1 filho MS porta/janela POSP AUX.1

'meu filho está na porta/janela'

(895) goj vũ ẽn te klãm tẽ água MS casa ESPEC POSP IMPERF

'tem água por baixo da casa' 
(896) põn vũ kózy klãm nẽ

cobra MS pedra POSP AUX.2

'a cobra está debaixo da pedra'

(897) glun vũ kul klãm nẽ

gato MS roupa POSP AUX.2

'o gato está debaixo da roupa'

(898) ẽn te ban kajãg vũ tẽ

casa ESPEC POSP cerca MS IMPERF

'a cerca está ao redor da casa'

(899) kózy te ẽn te la kabág tẽ

pedra ESPEC casa ESPEC POSP ADV IMPERF

'tem bastante pedra perto da casa'

(900) kãvãlu vũ ẽn te jy zán kũ jã

cavalo MS casa ESPEC POSP amarrar Cj AUX.1

'tem um cavalo amarrado na frente da casa'

(901) kózéj vũ ẽn te jy tẽ

mato/folha MS casa ESPEC POSP IMPERF

'tem mato na frente da casa'

(902) kó vũ kãggunh te jy jã

arvore MS nome masc. ESPEC POSP AUX.1

'tem uma madeira na frente do kãggunh'

(903) ẽn te ki óg kabág nõdẽ

casa ESPEC POSP 3P ADV AUX.1,2P

'na casa tinha bastante gente' 
(904) ẽnh ji vũ kózy klẽ nẽ

1 filho MS pedra POSP AUX.2

'meu filho está encima da pedra'

(905) txãggõnh vũ ẽn klẽ jã.

pássaro MS casa POSP AUX.1

'passarinho está em cima da casa'

(906) ẽn te la ta kutã MŨ

casa ESPEC POSP $3 \mathrm{M}$ cair PERF

'ele caiu perto de casas'

(907) mẽg vũ ẽn te la kyl jã

onça MS casa ESPEC POSP gritar/uivar AUX.1

'a onça está gritando/uivando perto de cas a'

(908) ti ji te vũ ti like tũ jã

3M filho ESPEC MS 3M POSP NEG AUX.1

'o filho dele não é parecido com ele'

(909) katxol tóg vũ ẽnh mãg like jã.

cachorro DEM MS 1 criação POSP AUX.1

'este cachorro é parecido com o meu xerimbabo'

(910) glun tóg vũ a mãg like nẽ

gato DEM MS 2 criação POSP AUX.2

'este gato é parecido com o seu xerimbabo'

(911) goj tá ta kyl jã.

água POSP 3M gritar AUX.1

'ele está gritando lá no rio' 
Há ainda outro tipo de predicado estativo que exprime um estado de dor, por exemplo. Neste caso o aspecto é o continuativo:

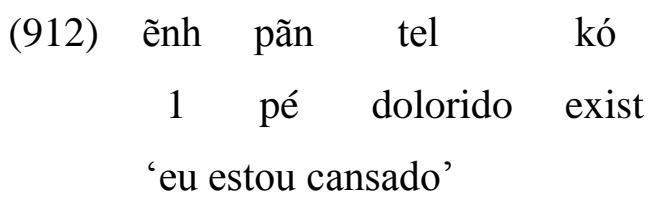

(913) a pãn tel vã

2 pé morrer/dolorido ESTAT

'você está cansado'

(914) ti pãn tel vã

$3 \mathrm{M}$ pé morrer ESTAT

' ele está cansado'

(915) zi pãn tel vã

3F pé morrer/ dolorido ESTAT

'ela está cansado'

(916) ãg pãn tel vã

1P pé morrer/ dolorido ESTAT

'nós estamos cansados'

(917) mẽ a pãn tel vã

2P pé morrer/ dolorido ESTAT

'vocês estão cansados'

(918) óg pãn tel vã

3P pé morrer/ dolorido ESTAT

'eles estão cansados'

Todos os predicados arrolados acima têm seus respectivos sujeitos marcados pela série pessoal 2. 


\subsection{PREDICADOS VERBAIS}

Predicados verbais são de dois tipos, transitivos e intransitivos, mas no aspecto continuativo são nominalizados e passam a ter as mesmas marcas pessoais que ocorrem com nmes e posposições. Assim, os sujeitos de predicados verbais são maracdos pela série 1,nominativa, mas se no aspecto continuativo, são marcados pela série 2. Predicados intransitivos têm o verbo em penúltima posição da sentença, seguidos pelas marcas de aspecto.

Exemplos contendo predicados intransitivos:

(919) gug vũ kó te ló taply mũ bugio MS arvore ESPEC POSP subir PERF 'o bugio subiu na árvore'

(920) ti ji vũ ẽn te ló lá MŨ $3 \mathrm{M}$ Filho MS casa ESPEC POSP entrar PERF 'filho dele entrou na casa'

(921) ẽn te pégjẽn ta tẽ MŨ casa ESPEC POSP 3M ESPEC PERF 'ele entrou ao redor da casa'

(922) kózy te pégjẽn nũ tẽ tẽ pedra ESPEC POSP 1P ir IMPERF 'eu vou entrar ao redor da pedra'

(923) goj te pégjẽn nũ katẽ MŨ água ESPEC POSP 1 mato PERF 'eu entrei ao redor da água/banhado'

(924) goj ki ta kutã MŨ 
água POSP $3 \mathrm{M}$ cair PERF

'ele caiu na água'

(925) mẽg vũ ti klẽ lãg MŨ

onça MS 3M POSP pular PERF

'a onça pulou por cima dele'

(926) zug

óg to ta tẽ MŨ

branco/estrangeiro $3 \mathrm{P}$ POSP $3 \mathrm{P}$ ir $\mathrm{PERF}$

'ele foi lá nos brancos'

(927) gal to ta ũ géj tẽ MŨ

milho POSP 3M OUTRO pegar/buscar ir PERF

'ele foi buscar um pouco de milho'

Predicados verbais intransitivos em orações que não possuem complementos circunstanciais podem ocupar a primeira posição da sentença, seguidos do sujeito e do auxiliar:

(928) jan nũ jã

cantar $\quad 1 \quad$ AUX.1

'eu canto/ eu estou cantando'

(929) jan mã jã

cantar $\quad 2 \quad$ AUX.1

'você canta/você está cantando'

(930) jan ta jã

cantar $3 \mathrm{M} \quad$ AUX.1

'ele canta/ele está cantando'

Predicados verbais transitivos vêm precedidos pelos seus respectivos objetos e seguidos de marcas aspectuais: 
(931) jug jé nũ kul kójam MŨ pai POSP 1 roupa comprar PERF 'comprei roupa para meu pai'

(932) ẽnh ji jé nũ kãnhglẽ vag MŨ 1P filho POSP 1 foice pegar PERF 'eu peguei foice para meu filho'

(933) ta vũ ẽ nõ zi jé klágnẽ bag MŨ 3M MS CORR mãe MG POSP carne pegar PERF 'ele trouxe/pegou carne para sua mãe'

(934) ti mõ ta kagklo vin mũ 3M POSP 3M peixe dar PERF 'ele deu peixe para ele'

(935) ta vũ $\tilde{e}$ mãg mõ goj nẽm mũ 3M MS CORR criação POSP água dar PERF 'ele deu água para seu xerimbabo/criação'

(936) kãggunh vũ ẽ jug mõ kãnhglẽ jig MŨ nome masc MS CORR pai POSP foice dar PERF 'kãggunh a deu para seu pai'

(937) kãggunh vũ ẽ ji blé pẽ géj tẽ MŨ nome masc. MS CORR filho POSP lenha/fogo pegar ir PERF 'kãggunh foi buscar lenha com seu filho'

(938) ẽnh jópõ tá nũ zazan vég MŨ 1 roça POSP 1 tatu ver PERF 'lá na minha roça eu vi um tatu' 
(939) ẽnh mãg vũ ti du tẽ MŨ

1 criação MS 3M POSP ir PERF

'o meu xerimbabo foi atrás dele'

(940) ãmẽdo zi vũ ti du tẽ MŨ

nome fem MG TRANS 3M POSP ir PERF

'ãmẽdo foi atrás dele'

(941) ẽ jug dun óg mũnh ke vã

CORR pai POSP 3P ir POSP ESTAT

'ele vão atrás do pai deles'

(942) ũn tõ pẽ péju mũ te vég tũ nũ mũ aquele TRANS lenha roubar PERF ESPEC ver neg 1 PERF eu não vi aquele que roubou a lenh a'

(943) ũn tõ katagãl javag mũ te óg kute te tá kamũ̃ mũ auqele TRANS nom.masc atirar PERF ESPEC 3P mato ESPEC POSP vir PERF os que atiraram em katagãl vieram da mat a'

(944) kózy ũ ban kũ ta tõ kó tóg ki pénũg mũ pedra OUTRO pegar CJ 3M TRANS árvore DEM POSP atirar PERF 'ele pegou uma pedra e atirou na árvore'

Os exemplos seguintes têm seus núcleos nominalizados, marcados pelos aspectos nominais prospectivo $k e$ e retrospectivo jó, razão pela qual os predicados combinam-se com o aspecto continuativo $v \tilde{a}$, caso em que o sujeito é marcado com $t i$ da série 2.

(945) ti blé óg kamũnh ke vã

$3 \mathrm{M}$ POSP $3 \mathrm{P}$ vir PROSP ESTAT

'eles vão vir com ele' 
(946) zi tõ kul zó jó vã

3F TRANS roupa lavar RETR ESTAT

'ela lavou roupa/ a roupa foi lavada por ela'

Em orações afirmativas a forma do sujeito dos verbos que fazem a distinção identifica um evento em andamento.

(947) ẽ txõ kó tóg kym vã

CORR TRANS árvore DEM cortar ESTAT

'é esta árvore que eu estou cortando'. 


\section{CAPÍTULO 5 - ALINHAMENTO EM LAKLÃNÕ}

\section{PRELIMINARES}

Neste capítulo tratamos da distribuição dos pronomes do Laklãnõ, com foco nos condicionamentos de sua distribuição. A nossa análise foi desenvolvida principalmente à luz dos estudos sobre alinhamento de Dixon (1994) e de Comrie (1981), mas respeitando a importante contribuição de Urban sobre alinhamento e tópicos relacionados em Laklãnõ.

Nenhum estudo sobre a gramática Laklãnõ pode ser feito sem por em relevo a fundamental contribuição de Greg Urban (1985) para a compreensão de princípios e parâmetros que norteiam a organização interna dessa língua. Os estudos de Urban são também um marco nos estudos sobre a morfossintaxe das línguas Jê, tanto sincronicamente quanto diacronicamente, como mostramos em Cabral, Gakran, Miranda, Martins e Silva (em preparação). ${ }^{29}$ Urban, fundado em seu refinado conhecimento da língua Laklãnõ, argumenta que esta língua apresenta um padrão complexo de ergatividade cindida, contrastando um padrão ergativo/acusativo que se manifesta formalmente em dois domínios:

(a) na marcação de caso em sintagmas nominais, incluindo a escolha de pronome e de partícula posposicional;

(b) na concordância de número no verbo.

Para Urban, duas variáveis condicionam o primeiro tipo de cisão, predicação estativa versus predicação ativa na oração principal e (2) a distinção entre oração principal e oração subordinada. O segundo tipo de cisão é condicionado pela distinção entre verbo e marca aspectual.

Os resultados do presente estudo, como veremos adiante, evidenciam que fatores de naturezas distintas atuam na distribuição dos nomes ou das marcas de pessoa em função argumentiva, embora o fator principal seja o aspecto.

\footnotetext{
${ }^{29}$ Trata-se de uma estudo histórico-comparativo sobre alinhamento na família Jê, fundado em dados de primeira mão coletados pelos autores deste estudo, junto a falantes da maioria das línguas que constituem a família Jê. O estudo associa-se a outros estudos desenvolvidos no âmbito do Projeto DESCRIÇÃO E COMPARAÇÃO HISTÓRICA DE LÍNGUAS DO TRONCO TUPÍ, na medida em que o tema em pauta é crucial para os estudos comparativos Jê e Tupí na perspectiva de que estes constituem um agrupamento genético.
} 
Neste capítulo, tratamos primeiramente da distribuição dos pronomes, e, em seguida, dos nomes, em função argumental.

\subsection{PARADIGMAS PESSOAIS}

Nesta seção descrevemos os paradigmas pessoais do Laklãnõ ilustrando as suas respectivas distribuições, já identificando e tecendo considerações sobre os fatores que condicionam o alinhamento desses paradigmas com os diferentes tipos de predicados.

Há em Laklãnõ três "paradigmas" pessoais, que aqui chamados de conjuntos pessoais.

Quadro 10 - Conjunto 1

\begin{tabular}{|c|c|c|c|c|}
\hline \multicolumn{3}{|c|}{ Singular } & \multicolumn{2}{|c|}{ Plural } \\
\hline $1^{\mathrm{a}} \mathrm{p}$ & nũ & $\mathrm{eu}$ & ãg & nós \\
\hline $2 \mathrm{P}$. & mã (ha) & tu & mã mẽ & vocês \\
\hline $\begin{array}{c}3^{\text {a }} \text { p. masc. } \\
\text { fem. }\end{array}$ & $\begin{array}{l}\mathrm{ta} \\
\mathrm{zi}\end{array}$ & $\begin{array}{l}\text { ele } \\
\text { ela }\end{array}$ & óg & $\begin{array}{l}\text { eles } \\
\text { elas }\end{array}$ \\
\hline $3^{\mathrm{a}} \mathrm{p}$. correferencial & & & $\tilde{\varepsilon}$ & \\
\hline
\end{tabular}

Quadro 11 - Conjunto 2

\begin{tabular}{|c|c|c|c|c|}
\hline \multicolumn{3}{|c|}{ Singular } & \multicolumn{2}{|c|}{ Plural } \\
\hline $1^{\mathrm{a}} \mathrm{p}$ & ẽnh & eu & ãg & nós \\
\hline 2P. & $\mathrm{a}$ & tu & mẽ a & vocês \\
\hline $\begin{array}{c}3^{\mathrm{a}} \text { p. masc. } \\
\text { fem. }\end{array}$ & $\begin{array}{l}\text { ti } \\
\text { zi }\end{array}$ & $\begin{array}{l}\text { ele } \\
\text { ela }\end{array}$ & óg & $\begin{array}{l}\text { eles } \\
\text { elas }\end{array}$ \\
\hline
\end{tabular}

Quadro 12 - Conjunto 3

\begin{tabular}{|c|c|}
\hline Singular & Plural \\
\hline
\end{tabular}




\begin{tabular}{|c|c|c|c|c|}
\hline $1^{\mathrm{a}} \mathrm{p}$ & ẽnh ja & $\mathrm{eu}$ & ãg ha & nós \\
\hline 2P. & a ha & tu & mẽ a ha & vocês \\
\hline $\begin{array}{c}3^{\mathrm{a}} \text { p. masc. } \\
\text { fem. }\end{array}$ & $\begin{array}{l}\text { ti vũ } \\
\text { zi vũ }\end{array}$ & $\begin{array}{l}\text { ele } \\
\text { ela }\end{array}$ & óg ha & $\begin{array}{l}\text { eles } \\
\text { elas }\end{array}$ \\
\hline
\end{tabular}

\subsection{A distribuição do conjunto I}

O conjunto 1 ocorre como sujeito de predicados intransitivos e transitivos, podendo os intransitivos terem por núcleo um verbo ou um nome, mas quando estes são marcados pelos aspectos perfectivo, imperfectivo e progressivo.

Quadro 13 - Conjunto 1

\begin{tabular}{|c|c|c|}
\hline \multicolumn{3}{|c|}{ Conjunto 1 } \\
\hline \multicolumn{2}{|c|}{ Sujeito } \\
\hline transitivo & intransitivo & predicados nominais \\
\hline \multicolumn{3}{|c|}{ aspectos perfectivo, imperfectivo e progressivo } \\
\hline \multicolumn{2}{|c|}{ Alinhamento nominativo } \\
\hline
\end{tabular}

\section{Predicados intransitivos}

Como vimos no capítulo 4, os predicados intransitivos podem ser verbais ou nominais. Os verbais têm como núcleo um verbo em sua forma finita, que é uma forma não derivada. trata-se do tema verbal básico, e o predicado de que é núcleo corresponde a um processo, um evento ou estado. Os predicados nominais têm como núcleo um nome, um verbo nominalizado ou um adjetivo.

\section{Predicado intransitivo, no aspecto progressivo}

Chamamos de aspecto progressivo, o aspecto que marca um processo verbal como estando em pleno desenvolvimento, e um estado em plena realização ou existência, tendo sido 
iniciado antes do momento da fala e podendo não ter um término definido, configurando-se em um intervalo, como o esquematizado em seguida:

O aspecto progressivo é expresso por meio de verbos posicionais (ver Capítulo 3, seção, 3.3.17, Verbos em Laklãnõ/Xokleng) e as marcas pessoais que se combinam com esse tipo de construção são as marcas do conjunto 1:

Evento em pleno desenvolvimento:

(948) jan nũ jã.

cantar 1 AUX.1

'eu canto/ eu estou cantando'

(949) jan mã jã.

cantar 2 AUX.1

'você canta/você está cantando'

(950) jan ta jã.

cantar $3 \mathrm{M} \quad$ AUX.1

'ele canta/ele está cantando'

(951) jan zi jã.

cantar $3 \mathrm{~F} \quad$ AUX.1

'ela canta/ela está cantando'

(952) jan nã nõdẽ

cantar 1P AUX.1,2P

'nós cantamos/nós estamos cantando'

(953) jan mã mẽ nãdẽ

cantar $2 \mathrm{P} \quad$ AUX.1,2P 
'vocês cantam/vocês estão cantando'

(954) jan óg nõdẽ

cantar 3P AUX.1,2P

'eles cantam/eles estão cantando'

Nessas construções, a posição de foco é ocupada pelo núcleo do predicado. Essa informação é importante porque o elemento que ocupa a posição de foco é determinante para a ocorrência ou não do conjunto 1 como sujeito.

Processo em desenvolvimento:

(955) mõg vũ pe kũ nõ

mõng MS diluir $\mathrm{Cj}$ AUX.3

'o mõg está diluindo'

(956) klángne nũ gla nẽ

carne MS assar AUX.2

'a carne está assando'

Estado que equivale a uma propriedade inerente:

(957) a ha mã téj jã

2 ENF 2P alto AUX.1

'você mesmo é alto'

(958) ta vũ téj jã

$3 \mathrm{M}$ MS alto AUX.1

'ele é alto'

01. zi vũ téj jã

3F MS alto AUX.1

'ela é alta' 


\subsection{Aspecto perfectivo}

$\mathrm{O}$ aspecto perfectivo corresponde a um evento ou processo que se encontra concluído, mas nada é dito sobre o fato de que foi esgotado ou não, apenas realizado.

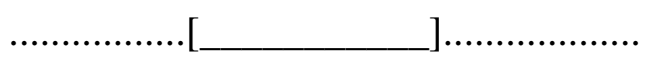

Nesse aspecto, o núcleo verbal se combina com o conjunto 1.

$\begin{array}{llll}\text { (959) } & \text { jan } & \text { nũ } & \text { MŨ } \\ & \text { cantar } & 1 & \text { PERF } \\ & \text { 'eu cantei/eu cantei' }\end{array}$

(960) jan mã MŨ

cantar 2 PERF

'você cantou/ você cantou'

(961) jan ta MŨ

cantar 3M PERF

'ele cantou/ele cantou'

(962) jan zi MŨ

cantar 3F PERF

'ela cantou/ela cantou'

(963) jan nã MŨ

cantar 1 PERF

'nós cantamos/nós já cantamos'

(964) jan mã mẽ MŨ

cantar 2P PERF

'vocês cantaram/vocês já cantaram' 
(965) jan óg MŨ

cantar 3P PERF

'eles cantaram/eles já cantaram'

Quando um pronome enfático, que é do conjunto 3, é expresso, este atrai o sujeito, que é do conjunto1, para a segunda posição, precedendo assim o núcleo verbal:

(966) ẽnh jã nũ kutã MŨ

1 ENF 1 cair PERF

'eu mesmo caí/ eu caí'

(967) a ha mã kutã MŨ

2 ENF 2 cair PERF

'você caiu/ você mesmo caiu.

Na terceira pessoa, o sujeito vem em primeira posição nesse aspecto.

(968) ta vũ kutã MŨ

$3 \mathrm{M}$ MS cair PERF

'ele caiu'

(969) zi vũ kutã MŨ

3F MS cair PERF

'ela caiu'

(970) ãg ha nã vál MŨ

1P ENF 1 cair (pl) PERF

'nós caímos/ nós mesmos caimos'

(971) mẽ mã vál MŨ

2P cair $(\mathrm{pl}) \quad$ PERF

'vocês caíram/ vocês mesmos caíram' 
(972) óg vũ vál MŨ

3P MS cair (pl) PERF

'eles caíram'

Vejamos exemplos com os verbos dormir:

(973) ẽnh jã nũ nũl mũ

1 ENF 1 dormir PERF

'eu dormi/ eu mesmo dormi'

(974) a ha mã nũl mũ

2 ENF 2 dormir PERF

'você dormiu/ você mesmo dormiu'

(975) ta vũ nũl mũ

3M MS dormir PERF

'ele dormiu'

(976) zi vũ nũl mũ

3F MS dormir PERF

'ela dormiu'

(977) ãg ha nã jãgnũl MŨ

1P ENF 1P dormir (pl.) PERF

'nós dormimos/ nós mesmos dormimos'

(978) mẽ mã jãgnũl MŨ

2P dormir (pl) PERF

'vocês dormiram/ vocês mesmos dormiram'

(979) óg vũ jãgnũl MŨ

3P MS dormir (pl) PERF

'eles dormiram' 
Independentemente do fato do verbo ser de movimento ou não, o padrão é o mesmo, como mostram os exemplos com o verbo chegar:

(980) ẽnh jã nũ tavig MŨ

1 ENF 1 chegar PERF

'eu cheguei'

(981) a ha mã tavig MŨ

2 ENF 2 chegar PERF

'você chegou/ você mesmo chegou'

(982) ta vũ tavig MŨ

3M MS chegar PERF

'ele chegou'

(983) zi vũ tavig MŨ

3F MS chegar PERF

'ela chegou'

Formas no plural:

(984) ãg ha nã jul MŨ

1P ENF 1P chegar (pl) PERF

'nós chegamos/ no mesmos chegamos'

(985) mẽ mã jul MŨ

2P chegar (pl.) PERF

'vocês chegaram/ vocês mesmos chegaram'

(986) óg vũ jul MŨ

3P MS jul PERF

'eles chegaram' 


\section{3.1 Aspecto Imperfectivo}

O imperfectivo ocorre com núcleo de predicados verbais, nominais ou adjetivais, mas nestes casos, em contextos bem específicos. O tẽ marca uma predicação como inacabada, cujo término não esta delimitado. Trata-se de um processo verbal que pode nem mesmo ter iniciado, mas estar apenas previsto. A imperfectividade tem um matiz de continuidade, de algo que se estende. Essa ideia é também presente quando o predicado tem por núcleo um nome ou um adjetivo.

$(987)$

$\begin{array}{lcc}\text { jan } & \text { nũ } & \text { tẽ } \\ \text { cantar } & 1 & \text { IMPERF }\end{array}$

'eu vou cantar/eu irei cantar'

(988) jan mã tẽ

cantar 2 IMPERF

'você vai cantar/você irá cantar'

(989) jan ta tẽ

cantar 3M IMPERF

'ele vai cantar/ele irá cantar'

(990) jan $\quad$ zi $\quad$ tẽ
cantar $3 F \quad$ IMPERF
'ela vai cantar/ela irá cantar'

Embora a tradução em Português desses exemplos corresponda ao futuro, em Laklãnõ não se trata de tempo, mas de um processo que se iniciou ou que foi projetado, mas cuja realização não foi concluída. 


\subsubsection{O imperfectivo e o matiz de continuidade}

(991) jan nã tẽ

cantar 1P IMPERF

'nós cantamos/nós estamos cantando'

(992) jan mã mẽ tẽ

cantar 2P IMPERF

'vocês cantam/vocês vão cantar'

(993) jan óg tẽ

cantar 3P IMPERF

'eles cantam/eles estão cantando'

(994) kózej vũ ẽn te ban kabág tẽ

Flor MS casa ESPEC POSP ADV IMPERF

'as flores estão ao redor da casa'

(995) kute vũ ẽn te ban tẽ

Mato MS casa ESPEC POSP IMPERF

'o mato esta ao redor da casa'

Quadro 14 - Conjunto 3

\begin{tabular}{|c|c|c|c|c|}
\hline \multicolumn{4}{|c|}{ Singular } & Plural \\
\hline $1^{\text {a }} \mathrm{P}$. & ẽnh ja & eu & ãg ha & nós \\
\hline $2 \mathrm{P}$. & a ha & tu & mẽ a ha & vocês \\
\hline $3^{\text {a P. Masc. }}$ & ti vũ & ele & óg ha & $\begin{array}{l}\text { eles } \\
\text { elas }\end{array}$ \\
Fem. & zi vũ & ela & & \\
\hline
\end{tabular}


Embora a partícula ha marque nomes para enfatizá-los, consideramos que eles já integram o paradigma pronominal 3, por ocorrer com regularidade não apenas em construções enfáticas, mas em construções em que são argumento em combinação com Posposições. $\mathrm{O}$ Conjunto 3 ocorre como sujeito de predicados no aspecto estativo:

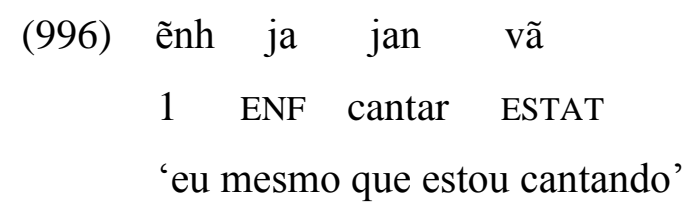

(997) a ha jan vã

2 ENF cantar ESTAT

'você mesmo está cantando'

(998) ti ha jan vã

$3 \mathrm{M}$ ENF cantar ESTAT

'ele mesmo está cantando'

(999) zi ha jan vã

3F ENF cantar ESTAT

'ela mesma vai cantar'

(1000) ãg ha jan vã

1P ENF cantar ESTAT

'nós mesmo estamos cantando'

(1001) mẽ a ha jan vã

2P ENF cantar ESTAT

'vocês mesmos estão cantando'

(1002) óg ha jan vã

3P ENF cantar ESTAT

eles mesmos estão cantando. 


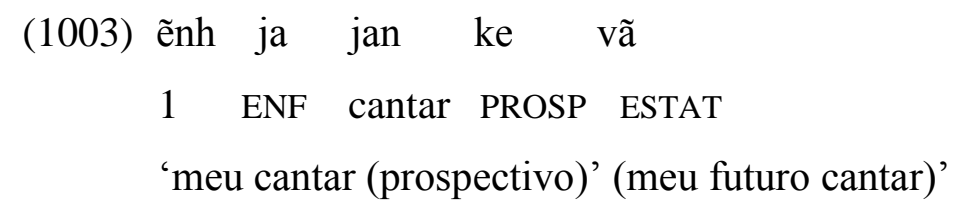

(1004) a ha jan ke vã

2 ENF cantar PROSP ESTAT

'é você que vai cantar'

(1005) ti ha jan ke vã

3M ENF cantar PROSP ESTAT

'ele mesmo vai cantar'

(1006) zi ha jan ke vã

3F ENF cantar PROSP ESTAT

'ela mesma vai cantar'

(1007) ãg ha jan ke vã

1P ENF cantar PROSP ESTAT

'nós mesmo iremos cantar'

(1008) mẽ a ha jan ke vã

2P ENF cantar PROSP ESTAT

'vocês mesmo irão cantar'

(1009) óg ha jan ke vã

3P ENF cantar PROSP ESTAT

'eles mesmos vão cantar'

Em construções comparativas, o elemento comparado é codificado pelo conjunto 3, no aspecto progressivo:

(1010) ẽnh já nũ jug like jã.

1 ENF 1 pai POSP AUX.1

'eu sou parecido com nosso pai' 
(1011) a ha mã ẽnh jug like jã

2 ENF 21 pai siml AUX.1

'você é parecido com o meu pai'

Ocorre também marcando o sujeito do verbo txul 'querer', que tem como objeto outro verbo em forma nominal.

(1012) ẽnh ja jan txul vã

1 ENF cantar querer ESTAT

'é o meu querer cantar' ou 'eu quero cantar'

Mas também no aspecto estativo:

(1013) a ha jan txul vã

2 ENF cantar querer ESTAT

'você quer cantar'

(1014) ti ha jan txul vã

3M ENF cantar querer ESTAT

'ele mesmo quer cantar'

(1015) zi ha jan txul vã

3F ENF cantar querer ESTAT

'ela mesma quer cantar'

(1016) ãg ha jan txul vã

1P ENF cantar querer ESTAT

'nós mesmos queremos cantar'

(1017) mẽ a ha jan txul vã

2P ENF cantar querer ESTAT

'vocês mesmos querem cantar' 
Ressalta o fato de que, quando o conjunto 3 é usado por ênfase, e não como argumento propriamente, ocorre em orações nos diferentes aspectos:

(1018) a ha mã ẽnh ki ãklég MŨ

2 ENF 21 POSP lembrar/saudade PERF

'você mesmo lembra de mim/ você tem saudade de mim'

(1019) a ha mã téj jã.

2 ENF 2 alto AUX.1

'você mesmo é alto'

\subsubsection{Aspecto progressivo}

(1020) ẽnh ja nũ a u vég jã

1 ENF 12 bonito ver AUX.1

'eu estou gostando de você/eu mesmo estou achando você bonito'

(1021) a ha u vég nũ jã

2 ENF bonito ver 1 AUX.1

'você está gostando de você/você mesmo está achando você bonito'

(1022) ti ha vũ a u vég jã

3M ENF MS 2 bonito ver AUX.1

'ele está gostando de você/ela mesmo está achando você bonito'

(1023) zi ha vũ a u vég jã

3F ENF MS 2 bonito ver AUX.1

'ela está gostando de você/ela mesmo está achando você bonito'

(1024) ãg ha nã a u vég nõdẽ

1P ENF 12 bonito ver AUX.1,2P

'nós estamos gostando de vocês/nós mesmos estamos achando você bonito' 
(1025) mẽ a ha u vég nã nõdẽ

2P ENF bonito ver 1 AUX.1,2P

'nós gostamos de vocês/ nós mesmos achamos vocês bonitos'

(1026) óg ha vũ a u vég nõdẽ

3P ENF MS 2 bonito ver AUX.1,2P

'eles estão gostando de vocês/eles mesmos estão gostando de você'

\subsubsection{Aspecto perfectivo}

(1027) ẽnh ja nũ ti tanh MŨ

1 ENF 1 3M matar PERF

'eu matei ele/ eu o matei'

(1028) a ha mã ti tanh MŨ

2 ENF 2 3M matar PERF

'você matou ele/ você o matou'

(1029) ta vũ ti tanh MŨ

3M MS 3M matar PERF

'ele matou ele/ ele o matou'

(1030) zi vũ ti tanh MŨ

3F MS 3M matar PERF

'ela matou ele/ ela o matou'

(1031) ãg ha nã ti tanh MŨ

1P ENF 1 3M matar PERF

'nós matamos ele/ nós o matamos'

(1032) mẽ mã ti tanh MŨ

2P 3M matar PERF

'vocês mataram ele/ vocês o mataram' 
(1033) óg vũ ti $\tanh \quad$ MŨ
3PP $\quad$ MS 33P matar PERF
'eles mataram ele/ eles o mataram'

(1034) ẽnh ja nũ ti kutxég MŨ

1 ENF $1 \quad 3 \mathrm{M}$ beliscar PERF

'eu belisquei ele/ eu o belisquei'

(1035) a ha mã ti kutxég MŨ

2 ENF 2 3M beliscar PERF

'você beliscou ele/ você o beliscou'

(1036) ta vũ ti kutxég MŨ

3M MS 3M beliscar PERF

'ele beliscou ele/ ele o beliscou'

(1037) zi vũ ti kutxég MŨ

3F MS 3M beliscar PERF

'ela beliscou ele/ ela o beliscou'

plural

(1038) ãg ha nã ti kutxég MŨ

1P ENF 1P 3M beliscar PERF

'nós beliscamos ele/ nós o beliscamos'

(1039) mẽ mã ti kutxég MŨ

2P 3M beliscar PERF

'vocês beliscaram ele/ vocês o beliscaram'

(1040) óg vũ ti kutxég MŨ

3P MS 3M beliscar PERF

'eles beliscaram/ eles o beliscaram' 
(1041) ãg ha nã ti lãg MŨ

1PP ENF 1PP 3P bater PERF

'nós batemos nele'

(1042) mẽ mã ti lãg MŨ

2P 3M bater PERF

'vocês bateram nele'

(1043) ta vũ dén ko MŨ

3M MS algo comer PERF

'ele comeu algo/ ele comeu'

(1044) zi vũ dén ko MŨ

3F MS algo comer PERF

'ela comeu algo/ ela comeu'

\subsubsection{Aspecto imperfectivo}

(1045) ẽnh ja nũ gal zég tẽ

1 ENF 1 milho ralar IMPERF

'eu vou ralar milho'

(1046) a ha mã gal zég tẽ

2 ENF 2 milho ralar IMPERF

'você vai ralar milho'

(1047) ti ha vũ gal zég tẽ

3M ENF MS milho ralar IMPERF

'ele vai relar milho'

(1048) zi ha vũ gal zég tẽ

3F ENF MS milho ralar IMPERF

'ela vai relar milho' 
(1049) ãg ha nã gal zég tẽ

1PP ENF 1PP milho ralar IMPERF

'nós iremos ralar milho'

(1050) mẽ a ha mã gal zég tẽ

2PP ENF 2 filho ralar IMPERF

'vocês vão ralar milho'

(1051) óg ha vũ gal zég tẽ

3P ENF MS milho ralar IMPERF

'eles estão ralando milho'

(1052) ẽnh ja nũ pẽ klég tẽ

1 ENF 1 lenha/fogo cortar IMPERF

'eu vou cortar lenha/ eu mesmo vou cortar lenha'

(1053) a ha mã pẽ klég tẽ

2 ENF 2 lenha/fogo cortar IMPERF

'você vai cortar lenha/ você mesmo vai cortar lenha'

(1054) ti ha vũ pẽ klég tẽ

3M ENF MS lenha/fogo cortar IMPERF

'ele vai cortar lenha/ ele mesmo vai cortar lenha'

(1055) óg ha vũ gal zég tẽ

3P ENF MS milho ralar imPERF

'eles vão ralar milho/ eles mesmos vão ralar milho'

(1056) ẽnh ja nũ pẽ klég tẽ

1 ENF 1 lenha/fogo cortar IMPERF

'eu vou cortar lenha/eu mesmo vou relar milho'

(1057) óg ha vũ pẽ klég tẽ

3P ENF MS lenha/fogo cortar IMPERF

'eles vão cortar lenha/eles mesmos vão cortar lenha' 
O fato de o conjunto 3 marcar o agente em construções como as exemplificadas acima, pode constituir um padrão ergativo, mas não são em si marcas ergativas.

O agente de verbos transitivos como ralar, cavar, pegar no aspecto progressivo e no estado de existência prospectivo e retrospectivo é marcado pelo conjunto 3 combinado com $\tilde{e}$ txõ, na primeira pessoa, e com tõ nas demais pessoas.

Apresentamos em seguida exemplos com o verbo 'ralar' no aspecto estativo. O agente é marcado por formas do conjunto 2 seguidas do translativo tõo, de forma que ẽnh txõ 'por você' corresponde a um agente periférico, mas como determinante de uma construção nominal, traduzível por 'o ralar dela por mim', ou 'de mim', seguindo um padrão ergativo, mas não são marcas propriamente ergativas.

$$
\begin{aligned}
& \text { (1058) ẽnh txõ gal ze vã } \\
& 1 \text { TRANS milho ralar ESTAT } \\
& \text { 'eu estou ralando milho' }
\end{aligned}
$$

$$
\begin{aligned}
& \text { (1059) a tõ gal ze vã } \\
& 2 \text { TRANS milho ralar ESTAT } \\
& \text { 'você está ralando milho' }
\end{aligned}
$$

$$
\begin{aligned}
& \text { (1060) } \text { ti } \quad \text { tõ } \quad \text { gal } \quad \text { ze vã } \\
& 3 \mathrm{M} \text { TRANS milho ralar ESTAT } \\
& \text { 'ele está ralando milho' }
\end{aligned}
$$

$$
\begin{aligned}
& \text { (1061) zi tõ gal ze vã } \\
& \text { 3F TRANS milho ralar ESTAT } \\
& \text { 'ela está ralando milho' }
\end{aligned}
$$

$\begin{array}{cccccccc}\text { (1062) } & \text { ẽnh } & \text { jã } & \text { ẽ } & \text { txõ } & \text { gó } & \text { kan } & \text { vã } \\ 1 & \text { ENF } & \text { CORRL } & \text { TRANS } & \text { terra } & \text { cavar } & \text { ESTAT } \\ \text { 'eu } & \text { estou cavando buraco' } & & & & \end{array}$




$$
\begin{aligned}
& \text { (1063) a ha tõ gó kan vã } \\
& 2 \text { ENF TRANS terra cavar ESTAT } \\
& \text { 'você está cavando buraco' }
\end{aligned}
$$

$$
\begin{aligned}
& \text { (1064) ti ha tõ gó kan vã } \\
& \text { 3M ENF TRANS terra cavar ESTAT } \\
& \text { 'ele está cavando buraco' }
\end{aligned}
$$

$$
\begin{aligned}
& \text { (1065) zi ha tõ gó kan vã } \\
& \text { 3F ENF TRANS terra cavar ESTAT } \\
& \text { 'ela está cavando buraco' }
\end{aligned}
$$

(1066) ãg ha tõ gó kan vã

1P ENF TRANS terra cavar ESTAT

'nós estamos cavando buraco'

$\begin{array}{llllll}\text { (1067) mẽ a ha tõ gó kan vã } \\ \text { 2P } & \text { ENF TRANS } & \text { terra } & \text { cavar } & \text { ESTAT }\end{array}$

'vocês estão cavando buraco'

(1068) óg ha tõ gó kan vã

3P ENF TRANS terra cavar ESTAT

'eles estão cavando buraco'

(1069) ẽnh jã ẽ txõ kagklo génh vã

1 ENF CORR TRANS peixe pegar ESTAT

'eu estou pegando peixe'

$$
\begin{aligned}
& \text { (1070) a ha tõ kagklo génh vã } \\
& 2 \text { ENF TRANS pexe pegar ESTAT } \\
& \text { 'você está pegando peixe' }
\end{aligned}
$$




\subsection{CONSTRUÇÕES COM O VERBO QUERER SEM ASPECTO NOMINAL}

Construções com o verbo querer sem aspecto nominal ocorrem no aspecto continuativo e, consequentemente, o núcleo do predicado é uma nominalização; a construção é, portanto, possessiva, sendo o possuidor marcado pela série 3 .

(1071) ẽnh jã ẽ txõ gal zenh ke vã 1 ENF CORRL TRANS milho ralar PROSP ESTAT 'eu quero ralar milho/eu mesmo quero ralar milho'

(1072) a ha tõ gal zenh txul vã 2 ENF TRANS milho ralar querer ESTAT 'você quer ralar milho/ você mesmo quer ralar milho'

(1073) ti ha tõ gal zenh txul vã 3M ENF TRANS milho ralar querer ESTAT 'ele quer ralar milho/ele mesmo quer ralar milho'

(1074) zi ha tõ gal ze txul vã 3F ENF TRANS milho ralar querer ESTAT 'ela quer ralar milho/ela mesma quer ralar milho'

(1075) ãg ha tõ gal zenh txul vã 1P ENF TRANS milho ralar querer ESTAT 'nos queremos ralar milho/ nos mesmos queremos ralar milho'

(1076) mẽ a ha tõ gal zenh txul vã 2P ENF TRANS milho ralar querer ESTAT 'vocês querem ralar milho/ vocês mesmos querem ralar milho'

(1077) óg ha tõ gal zenh txul vã 3P ENF TRANS milho ralar querer ESTAT 'eles querem ralar milho/ eles mesmos querem ralar milho' 
(1078) ẽnh ja ẽ txõ pẽ klenh txul vã

1 ENF CORRL TRANS lenha/fogo cortar querer ESTAT

'eu quero cortar lenh a'

(1079) a ha tõ pẽ klenh txul vã

2 ENF TRANS lenha/fogo cortar querer ESTAT

'você quer cortar lenha/você mesmo quer cortar lenha'

(1080) ti ha tõ pẽ klenh txul vã

3M ENF TRANS lenha cortar querer ESTAT

'ele quer cortar lenha/ ele mesmo quer cortar lenha'

(1081) zi ha tõ pẽ klenh txul vã

3F ENF TRANS lenha/fogo cortar querer ESTAT

'ela quer cortar lenha/ ela mesma quer cortar lenh a'

(1082) ãg ha tõ pẽ klenh txul vã

1P ENF TRANS lenha/fogo cortar querer ESTAT

'nós queremos cortar lenha/ nos mesmos queremos cortar lenh a'

(1083) mẽ a ha tõ pẽ klenh txul vã

2P ENF TRANS lenha/fogo cortar querer ESTAT

'vocês querem cortar lenha/ vocês mesmos querem cortar lenha'

(1084) óg ha tõ pẽ klenh txul vã

3P ENF TRANS lenha/fogo cortar querer ESTAT

'eles querem cortar lenha/ eles mesmos querem cortar lenha'

Construções com o prefixo correferencial $\tilde{\varepsilon}$

O prefixo correferencial $\tilde{\varepsilon}$ marca o sujeito de verbos intransitivos e o objeto de verbos intransitivos quando correferente com o sujeito da oração principal: 
(1085) ẽnh txõ ẽ lãn kũ ta plãl tẽ

1 TRANS CORR bater $\mathrm{Cj} \quad 3 \mathrm{M}$ chorar IMPERF

'ele vai chorar quando eu bater nele'

(1086) ẽ kutã kũ ta ẽ nẽga blónh mũ

CORR cair CJ $3 \mathrm{M}$ CORR braço quebrar PERF

'ele quebrou o braço quando ele caiu'

(1087) ẽ mãg lãg ta mũ kũ nũ ẽ txõ ve kũ ti

CORR criaçãobater $3 \mathrm{M}$ PERF $\mathrm{Cj} 1$ CORR TRANS ver $\mathrm{Cj} \quad 3 \mathrm{P}$

to jũ mũ

POSP brigar PERF

'ele bateu na criação dele e ao ver briguei com ele'

(1088) ẽnh txõ ẽ ve kũ zi ve kũ zi plã mũ

1 TRANS CORR ver $\mathrm{Cj} \quad 3 \mathrm{~F}$ ver $\mathrm{Cj} \quad 3 \mathrm{PF}$ chorar PERF

'quando eu a vi ela chorou'

(1089) ẽnh txõ $\quad \tilde{e} \quad$ kulynh ke kũ zi tõ like tũg vã 1 TRANS CORR pentear PROSP $\mathrm{Cj} \quad 3 \mathrm{M}$ TRANS POSP Neg ESTAT 'eu quero pentear ela, mas ela não está querendo'

A distribuição do morfema de terceira pessoa correferencial tem também uma distribuição absolutiva, marcando apenas sujeitos e objeto, mas nesse caso só quando é correferente com o sujeito da oração principal.

O correferencial $\tilde{\varepsilon}$ é também usado em nomes, cujo determinante também é correferente com o sujeito da oração principal, como mostram os seguintes exemplos.

(1090) kãggunh vũ ẽ jug mõ kãnhglẽ jig mũ nome masc TRANS CORR pai POSP foice dar IMPERF

'kãggunh a deu para seu pai' 
(1091) kãggunh vũ ẽ ji blé pẽ géj tẽ MŨ nome masc. MS CORR filho POSP lenha/fogo pegar ir PERF 'kãggunh foi buscar lenha com seu filho'

\subsection{SOBRE AS FORMAS VERBAIS SINGULARES E PLURAIS}

\section{Temas verbais e alinhamento}

Urban (1985) foi o primeiro a descrever um padrão ergativo no contraste entre formas verbais singulares e plurais. Nos intransitivos a concordância dessas formas é com o sujeito, mas nos intransitivos é o objeto:

Formas verbais intransitivas plurais concordam com sujeito plural Formas verbais transitivas plurais concordam com objeto plural

Da mesma forma:

Formas verbais intransitivas singulares concordam com sujeito singular Formas verbais transitivas singulares concordam com objeto singular

Os exemplos que seguem mostram esses contrastes:

(1092) kó gõngõn ta mũ, kũ ta mẽ kápũn MŨ árvore derrubar (pl) 3M PERF $\mathrm{Cj} 3 \mathrm{M}$ por tudo queimar (pl) PERF 'ele derrubou as árvores e ele queimou'

(1093) ta vũ kó gõn mũ, kũ ta zi klẽ nõ MŨ 3M MS árvore derrubar (sg) PERF $\mathrm{Cj} 3 \mathrm{M} 3 \mathrm{~F}$ encima cair/deitar PERF 'ele derrubou árvore e ele [árvore] caiu encima dela' 


\subsection{ALGUMAS CONSIDERAÇÕES FINAIS}

Vimos neste capítulo que o Laklãnõ possui três paradigmas nominais, o Conjunto 1 que funciona como sujeito de verbos intransitivos e transitivos nos aspectos progressivo, perfectivo e imperfectivo, e como sujeito de predicado com núcleo adjetivo verbalizado. Nesses casos o Laklãnõ exibe um alinhamento Nominativo, marcando todos os sujeitos de predicados nesses aspectos da mesma forma. Por outro lado, o Conjunto 2 marca o objeto de verbos transitivos e o sujeito de predicados no aspecto progressivo. Trata-se portanto de um alinhamento absolutivo.

O Conjunto 3 ocorre em função enfática e como agente de verbos como ralar, cortar e pegar, quando seus núcleos lexicais estão no estado aspectual prospectivo ou retrospectivo.

Quadro 15 - Distribuição dos pronomes pessoais

\begin{tabular}{|l|l|l|l|l|}
\hline Conj. 1 & Nominativo & $\begin{array}{c}\text { Sujeito de } \\
\text { verbo } \\
\text { transitivo }\end{array}$ & \multicolumn{2}{|c|}{ Sujeito de verbo intransitivo } \\
\hline & & & & \\
\hline Conj. 2 & Absolutivo & $\begin{array}{c}\text { Objeto de } \\
\text { transitivos }\end{array}$ & Sujeito de predicados nominais \\
\hline Conj. 3 & Enfático & & \multicolumn{2}{|c|}{} \\
\hline & & $\begin{array}{c}\text { Agente de verbos transitivos nominalizados, } \\
\text { transitivos como pegar, ralar e cortar, nos } \\
\text { aspectos lexicais retrospectivo e prospectivo. }\end{array}$ \\
\hline
\end{tabular}

Vimos também que há ainda duas manifestações de ergatividade, uma na distribuição do pronome reflexivo de terceira pessoa e outra nos verbos que têm formas singulares e plurais com distribição regulada pela pluralidade do sujeito de verbos intransitivos e pelo objeto de vevrbos transitivos.

Observamos que o conjunto 3, embora marque o que pode ser traduzido como agente, não é um conjunto ergativo, pois ocorre em outras funções inclusive funções não argumentais. Nos exemplos que seguem marcam o sujeito de intransitivos. 


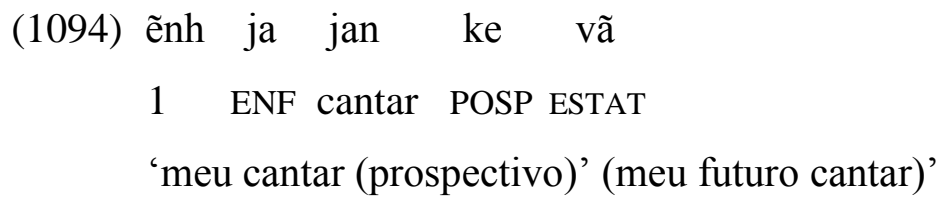

O quadro acima evidencia que o sistema de alinhamento do Laklãnõ é regido fundamentalmente por aspecto e pela natureza verbal ou nominal dos predicados (cf. CABRAL, GAKRÁN, M. SILVA, SILVA, MIRANDA, OLIVEIRA e C. SILVA, 2014) 


\title{
CAPÍTULO 6 - NEGAÇÃO
}

\section{PRELIMINARES}

\subsection{NEGAÇÃO DE PREDICADOS DE NATUREZA NOMINAL}

Negação em Laklãnõ segue os princípios básicos que norteiam a organização dessa língua. Predicados são de natureza verbal ou não verbal. Tratamos primeiramente a negação de predicados de natureza nominal e, em seguida, os de natureza verbal.

\subsection{NEGAÇÃO DE PREDICADOS DE NATUREZA NOMINAL}

Predicados de natureza processual, ou [- processo], se combinam com o morfema $t \tilde{u}$ 'privativo'. É o mesmo morfema que, combinado com nomes, contribui com o significado de 'destituído de algo', como mostram os exemplos seguintes:

(1098) klẽ kàgki tũ

cabeça cabelo sem

'sem cabelo (da cebeça)'

(1099) nẽga tũ

braço NEG

'sem cabeça'

Combina-se, assim, naturalmente com nomes e adjetivos acrescentando-lhes esse significado de privação, inclusive quando estes são núcleos de predicados:

\author{
(1100) ẽnh klã tũ vũ tẽ \\ 1 filho neg MS IMPERF \\ 'eu não tenho filho' ou 'eu sou sem filho'
}


(1101) kujel tũ nũ jã

fome NEG 1 AUX.1

'eu não estou com fome'ou 'eu sou sem fome'

(1102) ti mãg tõ katxol tũ vũ tẽ 3M criação TRANS cachorro Neg MS IMPERF

'ele não tem cachorro' ou 'eu sou sem cachrro'

(1103) ti jópõ bág tũ vũ tẽ

$3 \mathrm{M}$ roça grande Neg MS IMPERF

'ele não tem roça grande'ou 'ele é sem roça'

(1104) ẽnh jópõ bág tũ vũ tẽ

1 roça grande Neg MS IMPERF

'eu não tenho roça grande'ou 'ele é sem roça grande'

(1105) ẽnh kugklũ tõ gó tũ vũ tẽ

1 panela TRANS terra Neg MS IMPERF

'eu não tenho panela de barro'ou 'eu sou sem panela de barro'

(1106) ũ tóg li ta kutxó tũ tẽ

hoje $3 \mathrm{M}$ frio NEG IMPERF

'hoje não está frio'

(1107) vójóke kũ tó te kutã tũ tẽ cedo $\mathrm{Cj}$ chuva ESPEC cair NEG IMPERF 'não choveu hoje cedo'

Exemplos com tũ combinado com adjetivos são os seguintes:

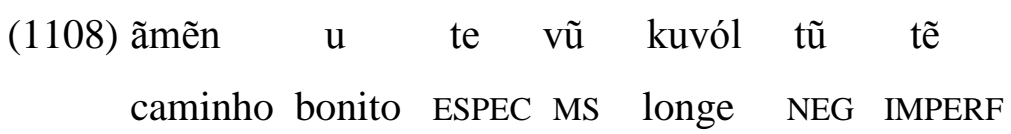


'a estrada boa não fica longe'

(1109) ẽnh ẽn te vũ katxin tũ jã

1 casa ESPEC MS pequeno NEG IMPERF

'minha casa não é pequena'ou 'minha csa é sem pequenez'

Predicados verbais

O morfema tũ se combina com verbos em suas formas nominalizadas de nome de ação, no aspecto imperfectivo:

(1110) jõ zi vũ tavi-g tũ tẽ

mãe MG MS chegar-NOM Neg IMPERF

'minha mãe não chegou'

(1111) kuzó te vũ tavi-g tũ tẽ?

velho ESPEC MS chegar-NOM NEG IMPERF

'o velho não chegou'

(1112) kulag gũ tó te kutã-nh ke tũ tẽ amanhã $\mathrm{Cj}$ chuva ESPEC cair-NOM PROSP Neg IMPERF 'amanhã não vai chover'

(1113) ẽnh jẽgga vũ bláj- $\emptyset$ tũ tẽ 1 braço MS quebrar-NOM Neg IMPERF 'meu braço não quebrou'

(1114) ẽnh jã nũ plãl- $\emptyset$ tũ tẽ 1 ENF 1 chorar-NOM NEG IMPERF 'eu mesmo não chorei'

(1115) ta vũ nũl- $\emptyset$ tũ tẽ 3M MS dormir-NOM Neg IMPERF ‘ele não dormiu' 
(1116) katxol te vũ ẽnh pla-g tũ tẽ cachorro ESPEC MS 1 morder-NOM Neg IMPERF 'O cachorro não me mordeu'

(1117) dén ko-nh ke tũ nũ tẽ algo comer-NOM POSP NEG 1 IMPERF 'eu não quero comer'

(1118) vãha tó te kutã tũ tẽ agora chuva ESPEC cair NEG IMPERF 'agora não está chovendo'

(1119) ẽnh jũgjẽn vũ vãnh-kym tũ tẽ 1 irmão MS Refl. cortar NEG IMPERF ‘meu irmão não se corto'

O morfema tũ também se combina com verbos, tanto intransitivos quanto transitivos:

(1120) ti lãg tũ nũ tẽ

$3 \mathrm{M}$ bater NEG $1 \mathrm{P}$ IMPERF

'eu não bati nele'

(1121) ẽnh mãg tõ kãvãlu te mõ nũ goj nẽm tũ tẽ 1 criação TRANS cavalo ESPEC POSP 1 água dar NEG IMPERF 'eu não dei água para a criação cavalo'

(1122) ẽnh mãg te mõ nũ vel péhov te nẽm- $\emptyset$ tũ tẽ 1 criação ESPEC POSP 1 ainda abobora ESPEC dar-NOM NEG IMPERF 'eu ainda não dei abóbora para a criação.

(1123) ta vu vel ẽnh lãg- $\emptyset$ tũ tẽ 3M MS ainda 1 bater-NOM NEG IMPERF 
'ele ainda não me bateu.

Quando um predicado no aspecto perfectivo é negado, é obrigatoriamente causativisado. Exemplos de predicados verbais negados no aspecto perfectivo são os seguintes:

(1124) ugby mõ zi goj nẽm- $\emptyset$ tũ $+g \quad$ MŨ

porco POSP $3 \mathrm{~F}$ água dar-NOM NEG+caus PERF

'ela não quis dar água para o porco'

(1125) zug te mõ ta lanhlanh- $\emptyset$ tũ-g MŨ

branco ESPEC POSP $3 \mathrm{M}$ trabalhar-NOM NEG-CAUS PERF

'ele não quis trabalhar para o branco'

(1126) 54. ãmẽdo zi mõ ta péhov nẽm- $\emptyset$ tũ-g MŨ nom. fem. MG POSP 3P abóbora dar-NOM NEG-CAUS PERF 'ele não quis dar abóbora para ãmẽdo'

(1127) jẽl óg mõ zi dénkónã vin- $\emptyset$ tũ-g MŨ criança 3P POSP 3F fruta dar-NOM NEG-CAUS PERF 'ela não quis dar frutas para as crianças'

(1128) kãggunh vũ ẽ ji mõ laglu nẽm- $\emptyset$ tũ-g mũ nom.masc TRANS CORR filho POSP feijão dar-NOM NEG-CAUS PERF 'kãggunh não quis dar feijão para seu filho'

\subsection{NEGAÇÃO DE COMANDOS}

Predicados no modo imperativo negados devem ser causativisados:
(1129) ko tũ +g ló!
comer NEG-CAUS POSP
'não coma!'
(1130) ló kala tũ $+g$ !
POSP entrar NEG-CAUS


'não entre!'

(1131) nẽ tũ-g ló!

sentar NEG-CAUS POSP

'não sente!'

(1132) ẽnh ji zi vũ ẽnh jõ péhov nẽm tũg MŨ

1 filho (a) MG MS 1 POSP abobora dar NEG PERF

'minha filha não quis dar abobora para mim'

Em Laklãnõ uma outra forma de negar se dá por meio do verbo denh 'negar'.

Exemplos disoo são:

(1133) ẽnh ji vũ ẽnh jõ laglu denh MŨ

1 filho(a) MS 1 POSP feijão negar PERF

'meu filho negou de dar o feijão para mim'

(1134) a ji te a mõ klágnẽ te denh MŨ

2 filho(a) ESPEC 2P POSP carne ESPEC NEGar PERF

'seu filho negou de dar uma carne para você'

(1135) ti ji te ti mõ kagklo te denh MŨ

3M filho(a) ESPEC 3M POSP peixe ESPEC negar PERF

o filho dele não quis dar peixe para ele.

(1136) óg mõ óg détéj te denh mũ

3P POSP 3P palmito ESPEC negar PERF

'eles negaram o palmito para eles'

(1137) ti nõ te zi ti mõ gal te denh MŨ

3M mãe ESPEC MG 3M POSP milho ESPEC negar PERF

'a mãe dele negou de dar o milho para ele' 
(1138) ãmẽdo zi vũ ẽ ji te mõ kul te denh MŨ nom.fem. MG MS CORR filho(a) ESPEC POSP roupa ESPEC negar PERF 'a ãmẽdo negou de dar a roupa para seu filho'

(1139) zug óg mõ óg kózy te denh MŨ branco 3PP POSP 3P pedra ESPEC nega PERF 'eles negaram para os brancos as pedras'

(1140) ẽnh txõ van kle te nũ ti mõ denh MŨ 1 TRANS taquara cortar ESPEC 1 3P POSP negar PERF 'eu neguei a taquara que eu cortei para ele'

(1141) ti ji te mõ nũ ẽnh do te denh MŨ 3M filh(a) ESPEC POSP 11 flecha ESPEC negar PERF 'eu neguei minhas flechas para o filho dele'

(1142) a mõ nũ ẽnh gal te denh MŨ 2 POSP 11 milho ESPEC negar PERF 'eu estou negando meu milho para você' 


\section{CAPÍTULO 7 - ORAÇÕES INTEROGATIVAS EM LAKLÃNÕ}

\section{PRELIMINARES}

Em Laklãnõ há dois tipos principais de perguntas, as que exigem um resposta sim ou não, e as perguntas que requerem uma resposta com conteúdo. Em perguntas, o constituinte questionado ou perguntado vem preferencialmente no início da oração.

As interrogativas que exigem uma resposta de conteúdo, questionam sobre argumentos, predicados e circunstâncias. Para as perguntas sobre argumentos, há, como vimos na seção 3.3.12, duas palavras interrogativas, uma que se refere a humanos, $\tilde{u}$, e outra a não humanos, de.

$\tilde{u}$ na função de sujeito:

(1143) ũ óg nũ vũ kamũ?

QUEM 3P interr. MS vir

'quem estão vindo?'

(1144) $\tilde{u} \quad$ nũ ki kajã?

QUEM interr. POSP chegando

'quem estão chegando?'

(1145) ũ nũ tóg ki pó mũ?

QUEM ind. interr. DEM POSP nascer PERF

'quem nasceu aqui?'

(1146) ũ nũ la ũ tá tóg ló katẽ mũ?

QUEM interr. ontem DEM POSP vir PERF

'quem veio aqui ontem?' 
$\tilde{u}$ na função de possuidor:

O exemplo seguinte contem (quem) em uma função possessiva, mas é a construção

(1147) ũ mãg nũ kájo jã?

QUEM. criação interr. magro AUX.1

'de quem é esta criação magra?'

$\tilde{u}$ na função de complemento de posposição:

companhia

(1148) ũ blé mã ẽn kuty te ló tẽ jé?

QUEM ind. POSP 2 casa escuro ESPEC POSP ir POSP

'com quem que você vai para a cidade?'

(1149) $\tilde{u}$ blé a ji te zi nẽ mũ?

QUEM ind. POSP 2 filho(a) ESPEC 3F sentar/casar PERF

'com quem que a sua filha se casou?'

recipiente

(1150) ũ mõ kuzó te klágnẽ te nẽm mũ ?

QUEM ind. POSP velho ESPEC carne ESPECdar PERF

'para quem o velho deu a carne?'

$\tilde{u}$ na função de agente:

(1151) ũ nũ ẽnh jõ kul tóg te nẽm mũ?

QUEM ind. interr. 1 POSP roupa DEM ESPEC dar PERF

'quem deu esta roupa para mim?'

(1152) ũ nũ a mõ laglu te nẽm mũ ?

QUEM ind. interr. 2 POSP feijão ESPEC dar PERF 
'quem deu o feijão para você?' 
Construções com de

(1153) tá tõ de zi nũ tõ a ji te plũ zi nẽ? mulher TRANS interr. 3PF intrr. TRANS 2P filho(a) ESPEC espora 3PF AUX.2 'qual dessas mulheres é a esposa do seus filho?'

(1154) glun tõ de nũ tõ ãmẽdo zi tũ nẽ? gato TRANS INTERR. INTERR. TRANS nom.fem. MG seu/sua AUX.2 'qual deste gato é o da ãmẽdo?'

(1155) ugby tõ de zi nũ tõ tá jã? porco TRANS que 3F INTERR. TRANS fêmea AUX.1 'qual dessas porca é fêmea?'

(1156) zug tõ de nũ ti tanh mũ? branco TRANS INTERR. INTERR. 3M matar PERF 'qual o branco que matou ele?

(1157) kálũ tõ de nũ jẽl te lãg mũ? rapaz TRANS INTERR. INTERR. criança ESPEC bate PERF 'qual dos rapazes que bateu na criança?'

(1158) klágnẽ tõ de ko nũ jé? carne TRANS INTERR. comer $1 \mathrm{P}$ POSP 'qual dessa carne eu vou comer?'

(1159) kó tõ de kym nũ jé? árvore TRANS interr. cortar $1 \mathrm{P}$ POSP 'qual dessa árvore eu vou cortar?'

(1160) tá tõ de zi nũ jé ẽn te ló la MŨ mulher TRANS INTERR. 3F INTERR. POSP casa ESPEC POSP entrar PERF 'qual destas mulher que entrou na casa?' 
Perguntas sobre circunstâncias de modo e de lugar são feitas com a combinação de posposições com os demonstrativos hã e õng:

lugar

(1161) hã ka a nũgjẽn te nẽ?

Interr. POSP 2 irmão ESPEC AUX.2

'onde mora seu irmão?'

(1162) hã ló a tẽg nũ vã?

Interr. POSP 2 ir 1 ESTAT

'aonde você vai indo? Para onde você está indo?'

(1163) hã tá a katẽg nũ vã?

Interr. POSP 2 vir 1 ESTAT

'de onde você está vindo?'

(1164) hã tá a jug te katẽg nũ vã?

Interr. POSP 2 pai ESPEC vir 1 ESTAT

'de onde veio o seu pai?'

(1165) hã tá a katẽg nũ vã?

Interr. POSP 2 vir 1 ESTAT

'de onde você está vindo?'

(1166) tóg ha ki mã pó mũ?

DEM ENF POSP 2 nascer PERF

'você nasceu aqui?/você nasceu aqui mesmo?'

modo

(1167) hã ló ke ló mã ẽn kuty ló tẽ jé?

Interr. POSP PROSP POSP 2 casa escuro/cheio POSP ESPEC POSP

'como você vai para a cidade?' 
(1168) hã like kũ mã kãj te han gég ke MŨ

Interr. POSP $\mathrm{Cj} 2 \mathrm{P}$ balaio/cesto ESPEC fazer HABIT PERF

'como você faz o cesto?'

(1169) hã like kũ katxol te ty mũ?

Interr. POSP $\mathrm{C} j$ cachorro ESPEC morrer PERF

'como o cachorro morreu?'

tempo

(1170) hã ló ke ló kuzó te a mõ gal te vin mũ ?

interr. POSP PROSP POSP velho ESPEC 2 POSP milho ESPEC dar PERF

'quando é que o velho deu o milho para você?'

(1171) hã ló ke ló a ji te pó mũ?

interr. POSP PROSP POSP 2P filho(a) ESPEC nascer PERF

'quando seu filho nasceu?'

O outro tipo de oração interrogativa em Laklãnõ, a interrogativa polar, é marcada pela entonação ascendente associada à posição inicial do que é questionado. Exemplos desse tipo e construcão são os seguintes:

Quando a situação de um argumento sujeito é questionado, este, além de vir em primeira posição, é marcado pelo especificador te, o que fortalece a idéia de que te é realmente um especificador, que, como tal, focaliza naturalmente o elemento que marca, seja esta função, seja a função de sujeito ou de agente:

(1172) pa'i

te plũ

jã?

chefe/autoridade ESPEC esposa/casado IMPERF

'o chefe é casado?/o chefe está casado?' 
(1173) Kãggunh te a mõ kul ũ nẽm mũ ? nom masc ESPEC 2 POSP roupa ESPEC Ind. dar PERF 'Kãggunh deu alguma roupa para você?'

(1174) jug te dén ko mũ ? pai ESPEC algo comer PERF 'meu pai comeu?'

(1175) a ve jé tẽ mũ?

2 ver POSP ir PERF

'ele foi visitar você?'

(1176) pẽ ũ gég mã mẽ kamũ mũ?

lenha ESPEC Ind. trazer 2 por tudo vir PERF 'vocês trouxemos alguma lenha?'

(1177) kul mẽ mã kulõn mũ? roupa por tudo 2 costurar PERF 'você costurou a roupa?'

(1178) kó ũ gõngõn mã mũ?' árvore DEM Ind. derrubar (pl) 2 PERF 'ele derrubou algumas árvores?'

(1179) ujol ũ tanh mã mũ? anta OUTRO matar 2 PERF 'você matou uma anta?'

(1180) jug te ugby tanh mũ?' pai ESPEC porco matar PERF 'meu pai matou o porco?' 
(1181) jõ te zi kul kágzag jã ?'

mãe ESPEC MG roupa lavar AUX.1

'minha mãe está lavando roupa ?'

(1182) põn te a mãg plag mũ?

cobra ESPEC 2 criação morder/picar PERF

'a cobra mordeu a sua criação?'

(1183) kózy te zi kanẽ mũ?

pedra ESPEC 3F bater PERF

'a pedra atingiu ela?/ a pedra bateu nela?'

Entretanto, se o sujeito ou agente não é o elemento questionado, não vem marcado por te. Nos exemplos seguintes, o elemento questionado é o objeto:

(1184) Gal kágklan mã mũ ?

milho plantar 2 PERF

'você vai plantar o milho?'

(1185) ti vég mã mũ?

$3 \mathrm{M}$ ver 2 PERF

'você viu ele?'

(1186) dén ko óg mũ?

algo comer 3P PERF

'eles comeram?'

(1187) ti lãg mã mũ?

$3 \mathrm{M}$ bater/surrar 2 PERF

'ele bateu nele?' 
Ilustramos agora complementos circunstanciais questionados:

(1188) ti blé mã lanhlanh mũ?

3M POSP 2 trabalhar PERF

'você trabalhou com ele?'

(1189) a mõ ta kójam mũ?

2 POSP 3P pagar PERF

'ele pagou para você?'

(1190) Kãggunh te ti blé blo mũ? nom masc ESPEC $3 \mathrm{M}$ POSP banhar PERF

'o Kãggunh tomou banho com ele?'

(1191) ti mõ ta kul ũ nẽm MŨ

3M POSP $3 \mathrm{M}$ roupa ESPEC Ind dar PERF

'ele deu alguma roupa para ele?'

(1192) ẽnh ji te gal ũ bag mũ?

1 filho(a) ESPEC milho DEM Ind. pegar PERF

'meu filho pegou algum milho?'

(1193) Kãggunh te lanhlanh jé?

nom masc ESPEC trabalhar POSP

'o Kãggunh vai trabalhar?'

(1194) goj te lõg mã jé?

água ESPEC esquentar 2P POSP

'você vai esquentar a água?'

(1195) jug te ujol klã kagmẽg mũ?

pai ESPEC anta filho/filhote pegar PERF

'meu pai pegou filhote de anta?' 
(1196) vãnh kym ta mũ?

Refl. cortar 3M PERF

'ele se cortou'

(1197) kól kũ nã ãklég mũ jã

depois $\mathrm{Cj}$ 1P caçar ir AUX.1

'depois vamos caçar?'

(1198) kaglo kónãg óg mũ mũ?

peixe procurar/pescar 3P ir PERF

'eles foram pescar?

(1199) põn te ti plag mũ?

cobra ESPEC 3M morder PERF

'a cobra mordeu ele?'

(1200) van ũ klég mã mũ?

taquara DEM Ind. cortar (pl.) 2 PERF

'você cortou algumas taquara?'

(1201) kãj kabág kághan mã mũ?

cesto/balaio bastante fazer 2 PERF

'você fez bastante cesto?'

(1202) goj te lõg mũ?

água ESPEC esquentar PERF

'a água esquentou?'

(1203) jug te tavig mũ?

pai ESPEC chegar PERF

'o meu pai chegou?' 
Exemplos em que o elemento questionado é o agente, mas o aspecto verbal é o estativo:

(1204) a tõ ẽnh txanh ke vã?

2 TRANS 1 matar PROSP ESTAT

'você vai me matar?'

(1205) a tõ ẽnh blé ke vã?

2 TRANS 1 POSP PROSP ESTAT

'você vai junto comigo?'

(1206) a tõ ugby tanh ke vã?

2 TRANS porco matar PROSP ESTAT

'você vai matar porco?

(1207) ti tõ ti lãn ke vã?

3M TRANS 3M bater PROSP ESTAT

'ele vai bater nele?'

(1208) a ha laglu vã?

2 ENF feijão ESTAT

'é seu este feijão?'

(1209) goj ló ti tẽ ke vã?

água POSP 3M ir PROSP ESTAT

'ele vai para o rio?'

Outro tipo de oração interrogativa em Laklãnõ é a que expressa finalidade. Este tipo de oração é o único em que o aspecto não é marcado. O verbo ocorre em sua forma nominalizada e se combina com a posposição jé. Exemplos são:

(1210) ẽnh jõ mã ũ nẽm jé?.

$1 \mathrm{P}$ POSP 2 DEM ind. dar POSP

'é para você me dar algum?' 
(1211) a mõ nũ ũ nẽm jé?

2 POSP 1 DEM ind. dar POSP

'é para eu dar algum para você?'

(1212) ti mõ mã ũ nẽm jé?

$3 \mathrm{M}$ POSP 2 DEM ind. dar POSP

'epara você dar algum para ele?'

(1213) vãnhkógtó kagklag mã jé?

remédio tomar 2 POSP

'é para você tomar remédio?'

(1214) ẽnh jõ mã ãgdénh jé ?

1 POSP 2 cozinhar POSP

'é para você fazer comida para mim?'

(1215) do ũ kághan mã jé?

flecha DEM ind. fazer 2 POSP

'você fez alguma flecha?'

(1216) kól kũ mã jan jé?

depois $\mathrm{Cj} 2$ cantar POSP

'depois é para você cantar?' 


\section{CAPÍTULO 8 - ORAÇÕES DE COMANDO}

\section{Modo imperativo}

Tratamos aqui de construções no modo imperativo. O modo imperativo é expresso por meio da combinação do tema verbal seguido ou precedido de Posposições: ló 'diretivo.1', que implica um deslocamento na direção de um lugar distante', $e$ ki 'inessivo dinâmico e/ou plural'.

Alguns exemplos de comandos no modo imperativo são:

(1217) ko ló!
comer POSP
'come!'

(1218) ki $\quad \tilde{\mathrm{u}} \quad \mathrm{ku}$

POSP ESPEC ind comer

'come um pouco!'

(1219) ugby bág te pénũ ló

porco ADV ESPEC atirar POSP

'atira no porco grande!'

(1220) katẽg ló

vir POSP

'venha'

(1221) katã ló

vir POSP

'venha!'

(1222) mẽ kaMŨ 
todos $\operatorname{vir}(\mathrm{pl}$.

'venha vocês!'

(1223) mẽ a ha kamũ

todos 2 ENF vir (pl.)

'venha vocês mesmos!'

Um outro tipo de comando é o 'permissivo' (cf. Rodrigues 1954), o qual tem o verbo nominalizado e o sujeito marcado pela posposição jé:

(1224) blo jé tẽ-g

banho POSP ir

'vai tomar banho!'ou 'ir para o banho!'

(1225) vãnhglén jé mũ jã-g

dançar POSP ir AUX.1

'vamos dançar, ou 'ir para dançar'

(1226) dén ko jé mũ jã-g?

algo comer POSP ir AUX.1

'vamos comer?'’ou 'ir para comer algo?'

(1227) ẽnh ve jé kala'

1 ver POSP entrar

'entrar para me ver!'

Construções negadas

(1228) mũ tũg jãg.

ir NEG AUX.1

'não vamos' 
A negação desse tipo de construção se dá com o morfema de negação tũ na última posição, combinada com o nominalizador de ação $-g,-n,-n h$. 
(1229) ẽnh ve jé kala tũg

1 ver POSP entrar NEG

'não entra pra me ver'

(1230) ẽnh blé mã nũl jé katẽ tũg mũ

1 POSP 2P dormir POSP vir NEG PERF

'não entra para dormir junto comigo' 


\section{CAPÍTULO 9 - CONSTRUÇÕES COMPARATIVAS}

\section{Tipos de comparações}

Em Laklãnõ, há dois tipos de comparações, de igualdade e contrastiva. As comparações de igualdade são feitas por meio de like 'similitivo' e as construções contrastivas são feitas por meio de kazyl 'contrário'. Apenas nominais são comparáveis em Laklãnõ. Há na comparação o elemento comparado e a referência da comparação. O elemento comparado é o o primeiro elemento da oração, a referência vem em seguida, marcada por like ou kazyl. O alinhamento é condicionado por aspecto, transitividade, pessoa e número.

No exemplo seguinte os elementos comparados são demonstrativos:

(1231) tóg vũ hã ta like nẽ

DEM MS aquele 3M POSP AUX.2

'este é parecido com aquele'

Os exemplos que seguem mostram um nome em relação comparativa com um demonstrativo ou pronome:

(1232) bég tóg vũ ẽnh txõ like nõ

machado DEM MS 1 TRANS SIMILAR AUX.3

'este machado é parecido com o meu'

(1233) kãnhglẽ tóg vũ a tõ like nõ foice DEM MS 2 TRANS SIMILAR AUX.3

'esta foice é parecida com a sua'

(1234) klãgdja tóg vũ ti tõ like nõ. foice DEM MS 3M TRANS SIMILAR AUX.3 'esta faca é parecida com a dele' 
(1235) kul tóg te vũ zi tõ like nẽ roupa DEM ESPEC MS 3F TRANS SIMILAR AUX.3

'esta roupa é parecida com a dela'

(1236) ugby tóg ũ ũn jã ta like jã porco DEM MS OUTRO ind. estar 3M SIMILAR AUX.1 'este porco é parecido com aquele lá'

(1237) glun ki nẽ tóg vũ ũ nẽ ta like nẽ gato POSP estar DEM MS OUTRO AUX.3 33P SIMILAR AUX.3 'este gato aqui é parecido com aquele ali'

(1238) ẽn jã ta ũ ũn ki jã tóg like jã casa este 3M MS ESPEC ind. POSP este DEM SIMILAR AUX.1 'aquela casa é parecida com esta daqui'

(1239) ẽn tóg vũ a tõ like jã casa DEM MS 2 TRANS SIMILAR AUX. 1 'esta casa é parecido com a sua'

(1240) ẽnh ji tóg vũ a ji like jã 1 filho DEM MS 2 filho SIMILAR AUX.1 'meu filho é parecido com seu filho'

(1241) ti ji te vũ ẽnh like jã 3M filho ESPEC MS 1 SIMILAR AUX.1 'o filho dele é parecido com meu filho'

(1242) glun tóg vũ ẽnh mãg like nẽ gato DEM MS 1 criação SIMILAR AUX.2 'este gato aqui é parecido com o meu' 
Construções comparativas envolvendo reciprocidade 'uns com os outros'

(1243) ẽn te vũ vãnhõ like tẽ casa ESPEC MS Refl. próprio SIMILAR IMPERF 'as casas são parecidas UMS com as outras'

(1244) kagklo tóg te vũ vãnhõ like nõdẽ peixe tóg ESPEC MS REFL.Próp SIMILAR AUX.1,2P 'estas peixe são parecidos umas com outras'

(1245) kagklo tóg óg vũ vãnhõ like nõdẽ peixe DEM 3P MS REFL.Próp SIMILAR AUX.1,2P 'estes peixes são parecidas um com os outros'

(1246) ũ óg vũ vãnhõ like kamũ? Interr 3P MS REFL.Próp SIMIL vir 'quem são estes que estão vindo parecido um com o outro?'

Os exemplos que seguem ilustram comparações contrastivas:

(1247) mẽg lál te vũ glun lál te kazyl kũ tẽ onça pintado ESPEC MS gato pintar ESPEC contr $\mathrm{Cj}$ IMPERF 'a pinta da onça é diferente da do gato'

(1248) kugkév nẽ te vũ txãggõnh nẽ te kazyl kũ tẽ galinha carne ESPEC MS pássaro carne ESPEC contr Cj. IMPERF 'a carne da galinha é diferente da carne de passarinho'

(1249) ug nẽ te vũ ugby nẽ ha like tẽ 'porco do mato carne ESPEC MS porco carne ENF SIMILAR IMPERF 'a carne do porco do mato é parecido com carne de porco' 
(1250) gug te vũ kójãl ha like tẽ

bugio ESPEC MS macaco ENF SIMILAR IMPERF

'o bugio é igual ao macaco'

(1251) ti ji te vũ ẽ jug te kazyl kũ jã (obs. objeto em pé)

3P filho ESPEC MS CORR pai ESPEC contr $\mathrm{Cj}$ AUX.1

'o filho dele é diferente do seu pai'

Elemento comparado marcado com o especificador te e elemento de referência da comparação pelo enfático ha:

(1252) a do te ẽnh txũ ha like nõdẽ

2 arco/flecha ESPEC 1 meu ENF SIMILAR AUX.1,2P

'seu arco e flecha são parecidos com os meus'

Exemplos com os dois elementos comparados marcados pelo especificador te:

(1253) gal blé laglu te vãnh kagzyl tẽ milho POSP feijão ESPEC Refl. contr IMPERF

'o milho e o feijão são diferentes uma do outro'

(1254) ãmẽn tóg ũ tẽ ta like tẽ

caminho DEM OUTRO ESPEC 3M SIMILAR IMPERF

'aquela estrada lá é parecida com esta daqui'

(1255) kó tóg vũ kó ũn jã ta like jã

árvore DEMMS árvore ARVORE ind. estar 3M SIMILAR AUX.1

'estas arvores aqui são parecidas com aquela arvore lá'

(1256) kãggunh vũ Dil ha like jã.

nom. masc MS nom.masc ENF SIMILAR AUX.1

'o kãggunh é parecido com o dil' 
(1257) Ãmẽdo zi vũ tálé zi like tũ jã

nom. fem MG MS nom. fem. MG SIMILAR NEG AUX.1

'a Ãmẽdo não é parecida com a Telé'

(1258) ẽn kuty tóg vũ ũ ta te like tũ tẽ

casa escuro DEM MS ESPEC ind 3M ESPEC SIMILAR NEG IMPERF

'esta cidade não é similar àquela outra'

(1259) ẽnh klãgdja bág vũ a tũ like nõ.

1P faca ADV MS 2 seu SIMILAR AUX.3

'meu facão grande é similar ao teu'

(1260) kugklũ nẽ ta vũ ẽnh ji zi tũ like nẽ panela estar 3M MS 1 filha 3F seu SIMILAR AUX.2

'aquela panela lá é parecida com a da minha filha'

(1261) dén kónã zy vũ tõ laglu like tẽ algo olho semente MS TRANS feijão SIMILAR IMPERF 'a sementa da fruta é similar ao feijão'

(1262) vo te vũ kuhánh like tẽ macuco ESPEC MS saracura SIMIL IMPERF 'o macuco é similar à saracura'

(1263) ti jópõ tẽ tóg vũ ẽnh txũ like tẽ $3 \mathrm{P}$ roça IMPERF DEM MS $1 \mathrm{P}$ seu SIMILAR IMPERF 'aquela roça dele é igual a minha'

Nas construções comparativas, o suejto de terceira pessoa recebe a marca nominativa vũ:

(1264) kul tóg te vũ vãnh kazyl kũ nõdẽ roupa DEM ESPEC MS Refl. contr Cj AUX.1,2P 
'estas roupas são diferentes uma das outras'

(1265) jug kyl vũ ti jug kyl like tũ tẽ pai grito MS 3M pai grito SIMILAR NEG IMPERF

'o grito do meu pai é diferente do grito do pai dele'

(1266) tá katẽ tóg te zi vũ ẽnh ji zi like katẽ mulher vir DEM ESPEC 3F MS 1 filho 3F SIMILAR vir 'a mulher que está vindo é parecida com minha filha'

(1267) ugby lá ki jã tóg vũ ũn jã ta like jã porco pintar POSP esta DEM MS OUTRO esta 3P SIMILAR AUX.1 'este porco pintado é parecido com aquele lá'

Por outro lado, o elemento comparado, quando é uma primeira ou segunda pessoa, esta é marcada pelo conjunto 3:

(1268) ẽnh já nũ jug like jã 1P ENF MS pai SIMILAR AUX.1 'eu sou parecido com meu pai'

(1269) a ha mã ẽnh jug like jã

2 ENF 211 pai SIMILAR AUX.1

'você é parecido com o meu pai' 


\section{CAPÍTULO 10 - COORDENACÃO E SUBORDINACÃO}

\section{Considerações iniciais}

Neste capítulo tratamos de coordenação e de subordinação em Laklãnõ. Discutimos os principais padrões que caracterizam as orações coordenadas, o modo como são coordenadas ou subordinadas, o sistema de correferência vigente e o alinhamento acionado. Distinguimos as orações coordenadas conjuntivas, que se coordenam por meio de um conectivo ou conjuntivo, das orações disjuntivas, que se coordenam por meio de morfemas disjuntivos.

\subsection{Coordenação conjuntiva}

Uma coordenação conjuntiva em Laklãnõ se faz por meio do conectivo $k \tilde{u}$, que une uma oração à outra. Esse conectivo é o primeiro elemento da segunda oração, membro da comparação. Vejamos alguns exemplos:

As coordenações seguintes consistem em duas orações cuja coordenação expressa sucessividade de ações:

(1270) jug vũ dén ko mũ, kũ ta vãha vãnhkán tẽ

pai MS algo comer PERF $\mathrm{Cj} 3 \mathrm{M}$ agora descansar IMPERF

'meu pai comeu, agora ele vai descansar'

(1271) jug blé nũ ugby tanh mũ kũ nã vãha kykym tẽ pai POSP 1 porco matar PERF $\mathrm{Cj} 1 \mathrm{P}$ agora cortar(pl) IMPERF

‘junto com meu pai matamos um porco e agora vamos cortá-lo’

(1272) jug vũ ẽ plũ zi mõ kulag hũ mã ẽnh jõ pai MS CORR mulher $3 \mathrm{~F}$ POSP amanhã $\mathrm{Cj} \quad 2 \quad 1 \quad$ POSP ãgdénh ke ta zi mõ mũ cozinhar POSP 3P 3F POSP PERF

'meu pai disse para sua mulher: amanhã você faz comida para mim'

(1273) ti blé nũ lanhlanh mũ, kũ ta ẽnh jõ kójam MŨ 3M POSP 1 trabalhar PERF $\mathrm{Cj}$ 3P 1 POSP pagar PERF 
'eu trabalhei com ele e ele me pagou' 
(1274) Kãggunh vũ ti lãg mũ, kũ ta ti tanh MŨ nom. masc MS 3M bater/surrar PERF $\mathrm{Cj} 3 \mathrm{M}$ 3M matar PERF 'Kãggunh bateu nele e ele o matou'

(1275) Kãggunh vũ ti lãg mũ, kũ ta ti tanh MŨ n.masc MS 3M bater/surrar PERF Cj 3M 3M matar PERF 'Kãggunh bateu nele e ele ao sentir, ele matou ele [Kãggunh]'

(1276) ti lãg nũ mũ, kũ nũ ti $\tanh$ MŨ 3M bater/surrar 1 PERF $\mathrm{Cj} \quad 1 \quad 3 \mathrm{M}$ matar PERF 'eu bati nele e eu o matei'

(1277) a lãg nũ mũ, mã kũ mã ẽnh txanh ke vã 2 bater/surrar 1 PERF ouvir/sentir $\mathrm{Cj} 21$ matar PROSP ESTAT 'eu bati em você e ao sentir você vai me matar'

(1278) ẽnh klẽ kóggó kó, kũ nũ vãnhkógtó kagklag MŨ 1 cabeça dor exist $\mathrm{Cj} 1 \mathrm{P}$ remédio tomar PERF 'eu estava com dor de cabeça e tomei remédio'

(1279) põn vũ ẽnh mãg plag mũ, kũ ta ty MŨ cobra MS 1P criação morder/picar PERF $\mathrm{Cj} 3 \mathrm{M}$ morrer PERF 'a cobra mordeu minha criação e ele morreu'

(1280) a blé nũ tẽ tẽ, kũ nã gég kamũ jã 2 POSP 1 ir IMPERF $\mathrm{Cj} 1$ pegar vir AUX.1 'eu vou junto com você e nós vamos pegar e trazer'

(1281) pẽ gég nã kamũ mũ kũ nã vãha klég tẽ lenha trazer 1 vir PERF $\mathrm{Cj} 1$ agora cortar IMPERF 'nós trouxemos lenha e agora nós vamos cortar' 
(1282) kózy ũ vũ tá tóg zi kanẽ mũ kũ ta zi kym MŨ pedra OUTRA MS mulher DEM 3F bater PERF $\mathrm{Cj}$ 3M 3F cortar PERF 'uma pedra atingiu essa mulher e feriu ela'

(1283) kó gõngõn ta mũ, kũ ta mẽ kápũn MŨ árvore derrubar (pl) 3M PERF $\mathrm{Cj} 3 \mathrm{M}$ por tudo queimar (pl) PERF 'ele derrubou as árvores e ele queimou'

(1284) ta vũ kó gõn mũ, kũ ta zi klẽ nõ MŨ 3M MS árvore derrubar (sg) PERF $\mathrm{Cj} 3 \mathrm{M} 3 \mathrm{~F}$ encima cair/deitar PERF 'ele derrubou a árvore e ela [árvore] caiu em cima dela'

Um outro tipo de construção coordenada dá uma ideia de sucessividade:

(1285) jõ zi vũ kul kágzag jã, kól kũ zi ãgdénh tẽ mãe MG MS roupa lavar AUX.1 depois $\mathrm{Cj} 3 \mathrm{~F}$ cozinhar IMPERF 'minha mãe está lavando roupa e depois ela vai cozinha [fazer comida]'

Note-se que kũ é uma partícula de primeira posição, exceto quando diante de kól 'depois',caso em que toma a segunda posição. Outros exemplos são:

(1286) Kãggunh vũ ti blé blo jã, kól kũ óg dén ko tẽ nom.masc MS 3M POSP banhar AUX.1 depois CJ 3P algo comer IMPERF 'Kãggunh está se banhando [tomando banho ] com ele e depois eles vão comer'

(1287) ta vũ a ve jé tẽ mũ, kól kũ ta katẽ tẽ 33P MS 2P ver POSP ir PERF depois CJ 33P vir IMPERF 'ele foi visitar você e depois ele vai vir'

(1288) ẽnh jõ mã ãgdénh jé nũ ku, kól kũ ẽnh jan ke vã 1 POSP 2 cozinhar POSP 1 comer depois $\mathrm{Cj} 1$ cantar PROSP ESTAT 'você cozinha para mim comer e depois eu vou cantar' 
(1289) jõ zi vũ kul kágzag jã kól kũ zi kul mẽ kulõn tẽ mãe $3 \mathrm{~F}$ MS roupa lavar estar depois $\mathrm{Cj} 3 \mathrm{~F}$ roupa $\mathrm{p} /$ tudo costurar IMPERF 'minha mãe está lavando roupa e depois vai costurar roupa'

(1290) tó kutãnh ke vã, kũ goj vũ vól tẽ chuva cair PROSP ESTAT $\mathrm{Cj}$ água/rio MS encher IMPERF 'vai chover e o rio/água vai encher'

(1291) dén jãnbe vũ kul klẽ pó mũ kũ ta zãgglyg mũ algo liquido MS roupa encima cair PERF $\mathrm{Cj} 3 \mathrm{M}$ sujar PERF 'óleo caiu na roupa e manchou'

(1292) ti tõ ti lãn ke vã, kũ ta ti tanh tẽ 3M TRANS 3M bater PROSP ESTAT $\mathrm{Cj} 3 \mathrm{M} 3 \mathrm{M}$ matar IMPERF 'ele vai bater nele e vai matar ele'

(1293) ẽn ji vũ gal bag mũ, kũ ta vãha kágklan tẽ 1 filho MS milho pegar PERF $\mathrm{Cj} 3 \mathrm{M}$ agora plantar IMPERF 'o filho dele pegou milho e agora ele vai plantar'

(1294) jug vũ ujol klã kagmẽg mũ, vãha ta ti jãhõn tẽ pai MS anta filho/filhote pegar PERF agora $3 \mathrm{M} 3 \mathrm{M}$ criar IMPERF 'meu pai pegou filhote de anta e agora ele [pai] vai criar ele [filhote de anta]'

(1295) goj ló ta tẽ mũ, ti tõ kózy géj tẽg vã água POSP 3M ir PERF 3M TRANS pedra pegar (pl) ir ESTAT 'ele foi para o rio, ele está indo pegar pedra'

(1296) gó tõ jym ke ku ta kutã mũ, kũ ta ẽ nẽgga blónh MŨ terra TRANS escorregar PROSP C $\mathrm{j} 3 \mathrm{M}$ cair PERF $\mathrm{Cj} 3 \mathrm{M}$ CORR braço quebrar PERF 'ele escorregou o barro e ele quebrou o braço' 
(1297) ti ji nẽgga vũ bláj mũ, kózy klẽ ti kutã kũ ti jógzẽ vã 3M filho braço MS quebrar PERF pedra encima $3 \mathrm{M}$ cair $\mathrm{Cj} 3 \mathrm{M}$ acontecer ESTAT 'o filho dele quebrou o braço, ele caiu encima da pedra onde aconteceu isso'

(1298) ẽnh mãg tõ katxol vũ ẽnh pãn pa ki plag mũ kũ 1 criação TRANS cachorro MS 1 pé enrolado POSP morder PERF Cj ta blinblil MŨ $3 \mathrm{M}$ rasgar PERF

'meu cachorro mordeu meu sapato e rasgou'

(1299) ẽnh klẽ kóggó kó, kũ nũ vãnhkógtó kagklag MŨ

1 cabeça dor exist $\mathrm{Cj} 1$ remédio tomar PERF 'eu estava com dor de cabeça e tomei remédio'

(1300) põn vũ ẽnh mãg plag mũ, kũ ta ty MŨ cobra MS 1 criação morder/picar PERF Cj 3M morrer PERF 'a cobra mordeu minha criação e ele morreu'

(1301) ẽnh blé mã lanhlanh, kũ nã gal kágklan jã 1 POSP 2 trabalhar $\mathrm{Cj} 1$ milho plantar AUX. 1 'você trabalha comigo e vamos plantar milho'

(1302) a ha mã ti vég mũ, kũ ta tohãnh ge MŨ

2 ENF 2 3M ver PERF Cj $3 \mathrm{M}$ vergonha HAB PERF 'você mesmo viu ele e ele ficou com vergonha'

(1303) a blé nũ tẽ tẽ, kũ nã gég kamũ jã 2 POSP 1 ir IMPERF $\mathrm{Cj} 1$ pegar vir AUX.1 'eu vou junto com você e nós vamos pegar e trazer'

(1304) ti mõ mã kul ũ nẽm, kũ mã ti blé ló MŨ 3M POSP 2 roupa ESPEC Ind dar CJ 2 3M POSP POSP PERF 'você da uma roupa para ele e você vai junto com ele lá' 
(1305) ta vũ a ve jé tẽ mũ, kól kũ ta katẽ tẽ

3M MS 2 ver POSP ir PERF depois CJ 3M vir IMPERF

'ele foi visitar você e depois ele vai vir'

(1306) ẽnh jõ mã ãgdénh jé nũ ku, kól kũ ẽnh jan ke vã

1 POSP 2 cozinhar POSP 1 comer depois $\mathrm{Cj} 1$ cantar PROSP ESTAT

'você cozinha para mim comer e depois eu vou cantar'

\subsection{Subordinação temporal}

Há um tipo de oração coordenada que, semanticamente, corresponde ao que em outras línguas é uma relação de subordinação temporal:

(1307) a tavi kũ mã vãnhkán ló

2 Chegar $\mathrm{Cj} 2$ descansar POSP

'você chegando, eu vou descansar' ou 'quando você chegar você vai descansar'

(1308) a tavi kũ nũ nũl tẽ

2 chegar $\mathrm{Cj} 1$ dormir IMPERF

'quando você chegar eu vou dormir'

(1309) ẽnh txẽg ve kũ mã zazan jé ãklég tẽg

1 ir ver $\mathrm{Cj} 2$ tatu POSP caçar IMPERF

'quando eu for você vai caçar tatu'

(1310) ẽnh txẽ kũ mã kul kágzó jé tẽg

1 ir $\mathrm{Cj} 2$ roupa lavar POSP IMPERF

'quando eu for, você vai lavar roupa'

(1311) ẽnh txẽ kũ nũ kó mẽ pankég tẽ

1 ir CJ 1 madeira tudo raspar IMPERF

'quando eu for embora eu vou raspar madeira'

(1312) a tõ ẽnh lãn kũ mã plãl tẽ

2 TRANS 1 bater $\mathrm{Cj} 2$ chorar IMPERF

'quando você me bater você vai chorar' 
(1313) a tõ ẽnh lãn kũ nũ plãl tẽ

2 TRANS 1 bater $\mathrm{Cj} 1$ chorar IMPERF

'quando você me bater, eu vou chorar'

(1314) ãg tõ ujol tanh kũ nã ti nẽ te mẽ glag tẽ 1P TRANS anta matar $\mathrm{Cj} \quad 13 \mathrm{M}$ carne ESPEC todo assar IMPERF 'quando nós matamos anta, nós assamos carne dela'

Neste tipo de coordenação, a oração semanticamente subordinada, não recebe marca de aspecto, e exibe um padão ergativo absolutivo. Já a segunda oração ocorre no aspecto imperfectivo.

\section{Finalidade}

As orações que exprimem finalidade são finais e, como as orações que exprimem relação temporal exibem um padrão absolutivo.

(1315) ẽnh txẽg vã ẽnh jógklénh jé.

$1 \mathrm{P}$ ir ESTAT 1 caçar POSP

'eu fui para caçar'

(1316) ujol tanh nũ mũ ẽnh txõ ko jé

anta matar 1 PERF 1 TRANS comer POSP

'eu matei anta para comer'

(1317) kuty tá nũ nũl tũ tẽ ẽnh txõ ẽnh ji tõlẽl jé noite POSP 1 dormir NEG IMPERF 1 TRANS 1 filho cuidar POSP 'eu entrei de noite acordado para cuidar do meu filho'

\section{Condição}

As orações que exprimem condição se caracterizam como circunstâncias e são, na realidade, sintagmas posposicionais, de forma que o padrão é uma padrão que poderíamos chamar de ergativo. 
(1318) zi tõ ẽnh jógzõg ló nũ zi blé nẽ tẽ

3F TRANS 1 amar/afeto POSP $13 \mathrm{~F}$ POSP sentar IMPERF

'se ela me amasse eu casaria com el a'

Outro tipo de construção que exprime condição se caracteriza por ser uma sintagma nominal modificado pelo demonstrativo hã ta.

(1319) sukita zi klã nẽ hã ta te kũ nũ ki ũ nom. anim. MG gravida está DEM 3M ESPEC Cj 1 POSP ESPEC Ind. bag tẽ pegar IMPERF

'se sukita estiver grávida eu quero um filhote dela'

(1320) tó kutã hã ta te kũ nã ẽn te ki nỹ tẽ chuva cair DEM 3M ESPEC Cj 1 casa ESPEC POSP estar (pl.) IMPERF 'se chover nós vamos ficar em casa'

(1321) 17. zi vãnhkulég hã ta te ve kũ nũ plãl tẽ $3 \mathrm{~F}$ triste DEM ESPEC ver $\mathrm{Cj} 1$ chorar IMPERF 'se ela está triste eu choro'

(1322) zi kóggó jãg hã ta te kũ nũ zi tõlẽl tẽ 3F doente estar DEM ESPEC Cj 1P 3PF cuidar IMPERF 'se ela está doente eu vou cuidar dela'

(1323) a tõ ẽnh lãn kũ nũ plãl tẽ 2 TRANS 1 bater $\mathrm{Cj} 1$ chorar IMPERF 'se você me bater, eu choro'

(1324) a plãl hã ta te kũ nũ a lãg tẽ 2 chorar DEM ESPEC $\mathrm{Cj} 12$ bater IMPERF 'se você chorar eu bato em você'

(1325) tá te zi u hã ta te kũ nũ zi blé vẽ tẽ mulher ESPEC 3PF bonita DEM ESPEC Cj 1P 3PFPOSP falar IMPERF 'se a mulher for bonita eu quero namorar com ela' 
(1326) 
(1327) Maná tẽg hã ta te kũ nũ vãtxuke jã tẽ nom. pro. ir DEM 3M ESPEC Cj 1 sozinho estar IMPERF 'se Maná for embora eu vou ficar sozinho'

(1328) a tõ gal ko bág hũ mã dug kóggó tẽ 2 TRANS milho comer ADV CJ 2 barriga doer IMPERF 'se você comer milho demais você vai ter dor de barriga'

\section{Explição}

Um outro tipo de coordenação exprime uma explicação, uma razão. A oração que traz a explicação ocorre marcada nos aspecto perfectivo e a oração principal no aspecto continuativo. A primeira, em um padrão nominativo e a segunda em um padrão ergativo.

(1329) un ke ta mũ ẽnh txõ ti mõ zégke vã parar PROSP 3M PERF 1 TRANS 3M POSP pedir ESTAT 'ele parou porque eu pedi'

(1330) kagklo kónãg nã mũ mũ like te jé ãg jãn tũ vã peixe procurar 1 ir PERF POSP ESPEC POSP 1P comida NEG ESTAT 'nós pescamos porque não tinha comida em casa'

(1331) ẽnh dén ko bág gũ nũ kóggó jã 1 algo comer ADV $\mathrm{Cj} 1$ doente AUX.1 'eu comi muito por isso fiquei doente'

(1332) ẽ txõ ẽ lãn kũ ta plãl tẽ CORR TRANS CORR bater $\mathrm{Cj} \quad 3 \mathrm{M}$ chorar IMPERF 'quando eu bater nele, ele vai chorar'

(1333) ẽ kutã kũ ta ẽ nẽga blónh mũ CORR cair $\mathrm{Cj}$ 3M CORR braço quebrar PERF 'quando ele caiu, ele quebrou o braço' 
$\begin{array}{lllllllllll}\text { (1334) ẽ mãg lãg } & \text { ta } & \text { mũ } & \text { kũ } & \text { nũ } & \tilde{e} & \text { txõ } & \text { ve } & \text { kũ } & \text { ti }\end{array}$ $\begin{array}{lllllllll}\text { CORR criação bater } & 3 \mathrm{M} & \mathrm{PERF} & \mathrm{Cj} & 1 & \text { CORR } & \text { TRANS ver } & \mathrm{Cj} & 3 \mathrm{M}\end{array}$ to jũ mũ

POSP brigar PERF

'ele bateu na criação dele e ao ver briguei com ele'

(1335) ẽ txõ è ve kũ zi ve kũ zi plã mũ CORR TRANS CORR ver $\mathrm{Cj} \quad 3 \mathrm{~F}$ ver $\mathrm{Cj} \quad 3 \mathrm{~F} \quad$ chorar PERF 'quando eu a vi ela chorou'

(1336) $\tilde{e}$ txõ ẽ kulynh ke kũ zi tõ like tũg vã $\begin{array}{llllll}\text { CORR TRANS CORR pentear PROSP } \mathrm{Cj} & 3 \mathrm{~F} & \text { TRANS POSP NEG ESTAT }\end{array}$ 'eu quero pentear ela, mas ela não está querendo' 


\section{CONCLUSÃO}

Neste tese de doutorado, apresentamos um primeira descrição aprofundada das classes de palavras da língua Laklãnõ. Trouxemos contribuições que julgamos importantes para a caracterização morfológica e morfossintática dos elementos das diferentes classes. Contribuimos para a descrição dos sistema de alinhamento vigente na língua e primeiramente estudado por Urban (1985). Ampliamos o estudo linguístico da língua apresentando uma descrição dos diferentes tipos de perguntas, das estratégias de negação, dos tipos de predicados e das estratégias de combinações de orações em sentenças mais largas.

Esta tese contou com a experiência cultural de um falante Laklãnõ, o que foi fundamental para uma descrição de aspectos da língua que são altamente dependentes da experiência de quem pertence ao mundo Laklãnõ, como os significados metafóricos de inúmeras construções que só têm sentido para os viventes no seio da cultura Laklãnõ.

Esperamos que este trabalho estimule e inspire os jovens professores Laklãnõ para que ampliemos cada vez mais o conhecimento linguístico da língua Laklãnõ e para que juntos procuremos desenvolver diferentes estratégias para o fortalecimentos da língua e da cultura do nosso povo indígena que tem resistido a tantas forças externas contrárias à sua sobrevivência. 


\section{REFERÊNCIAS BIBLIOGRÁFICAS}

BENVENISTE, E. Problèmes de linguistique générale. Vol. I, Paris: Gallimard, 1966.

. Problèmes de linguistique générale. Vol. II, Paris: Gallimard, 1974.

CABRAL, A.S.C., RODRIGUES, A. D. Línguas Indígenas Brasileiras: Fonologia, Gramática e História. Atas do $1^{\circ}$ encontro internacional do Grupo de Trabalho sobre Línguas indígenas da ANPOLL, vol.1. Belém: EDUFPA, 2002.

CAVALCANTE, Marita Pôrto. Fonologia e morfologia da língua Kaingáng : o dialeto de São Paulo comparado com o do Paraná. (Tese de Doutorado). Campinas: UNICAMP, 1987.

1987. Fonologia do Karajá. Revista do Museu Antropológico. Goiânia: Universidade Federal de Goiás, n.1, p.63-76. [Linguística]

. s.d. A derivação de formas intransitivas no Kaingáng do Paraná. Campinas, Unicamp. 21p. Cópia arquivada no CEDAE-IEL-Unicamp.

COMRIE, Bernard. Aspect. An introduction to the study of verbal aspect and related problems. Cambridge: Cambridge University Press, 1976.

Language universals and linguistic typology: syntax and morphology. Oxford/Chicago: University of Chicago Press, 1987.

COSTA, Lucivaldo Silva da. Flexão relacional, marcas pessoais e tipos de predicados em Xikrín: contribuição para os estudos sobre ergatividade em línguas Jê. Dissertação de Mestrado. Bélem : UFPA, 2003.

COSERIU, E. Sobre las categorías verbales (partes de la oración). Revista de Linguística Aplicada 10:7-25. Concepción, 1972.

CUNHA, Lauro Pereira da. Índios Xokleng e colonos no litoral norte do Rio Grande do Sul (século XIX). Porto Alegre, Evangraf, 2012.

D’ANGELIS, Wilmar da Rocha. 1991. Fonologia de um dialeto Kaingáng (Brasil). Exercício de aplicação da teoria dos traços distintivos. Campinas: IEL-Unicamp. 34p. Trabalho não publicado. Cópia arquivada no CEDAE-IEL-Unicamp.

Gênero em Kaingáng? I ENCONTRO SOBRE LÍNGUAS JÊ. Londrina: UEL, 2001. Edição eletrônica: http://www.lafape.iel.unicamp.br/ Publicações/GENERO.pdf.

DIXON, R.M.W. Ergativity. Cambridge: Cambridge University Press, 1994.

FERREIRA, M. de N. de O. Estudo morfossintático da língua parkatejê. Tese de Doutorado. Campinas: Universidade Estadual de Campinas, 2003.

Aspectos das classes de palavras em Parkatêjê: uma abordagem tipológicofuncional. In CABRAL, Ana Suelly Arruda C. \& RODRIGUES, Aryon D. (org). Estudos sobre línguas indígenas I. Belém: UFPA, 2001.

GAKRAN, Nanbla. Aspectos morfossintáticos da língua Laklãnõ (Xokleng). Dissertação de Mestrado. Campinas: UNICAMP, 2005.

GRINEVALD, Colette. Nominal classification in Movima. In : CREVELS, Mily. KERKE, Simon van de. MEIRA, Sérgio. VOORT, Hein van der (eds.). Current Studies on South American Languages. Leiden: Research School of Asian, African, and Amerindian Studies (CNWS), 2002. 
GUÉNTCHEVA, Zlatka. Modélisation de l'aspectualité et de la temporalité : intervalles topologiques et référentiels temporels. (illustration avec des exemples en français). Pour:18e Congrès des romanistes scandinaves. Université de Göteborg, 9-12 août 2011.

GUÉNTCHEVA Zlatka. Théorie énonciative et modalisation de l'aspect et du temps: concepts aspectuels de base, référentiels temporels et intervalles topologiques de représentation. Workshop Sobre, tempo aspect e modalidade em Linguas indigenas sulamericana. Brasilia: Instituto de Letras/LALLI, 2012.

GUÉNTCHEVA Zlatka. Temps et aspect: l'exemple du bulgare littéraire contemporain, Collection Sciences duLangage, Paris: Presses du CNRS, 1990.

HENRY, Jules. A Kaingáng text. International Journal of American Linguistics. Vol. 8. 3-4: 172218. 1935.

KAUFMAN, Terrence. Language history in South America: what we know and how to know more. In PAYNE, Doris L. (Ed.). Amazonian Linguistics. Studies in Lowland South American Languages. Austin: University of Texas Press, p.13-67. 1990.

MIRANDA, Maxwell. Morfologia e morfossintaxe da língua Krahô (família Jê, tronco MacroJê). (Tese de Doutorado). Programa de Pós-Graduação em Linguística. Brasília: Universidade de Brasília, 2014.

MOREIRA NETO, Carlos de Araújo. Alguns dados para a História recente dos índios Kaingáng. In: GRUNBERG, Georg (ed). La situación del Indígena em América del Sur. Montevideu, Tierra Nueva, 1972.

PIKE, Kenneth. Phonetics a Critical Account of Phonetic Theory and a Techinique for the Pratical Description of Sounds. Ann Arbor. The University of Michigan Press, 1943.

. Phonemics a Techinique for Reducing to Writing. Ann Arbor. The Universite or Michigan Press, 1947.

RICARDO, Carlos Alberto. "Os índios" e a sociodiversidade nativa contemporânea no Brasil. In: SILVA, Aracy Lopes da \& GRUPIONI, Luís Donisete Benzi. A temática indígena na escola: novos subsídios para professores de $1^{\circ}$ e $2^{\circ}$ graus. Brasília: MEC/MARI/UNESCO, 1995.

RODRIGUES, Aryon Dall'Igna. The present State of the study of Brazilian Indian languages. In: KLEIN, H. E. M.; STARK, L. R. (Ed.). South American Indian Languages. Austin: University of Texas Press. p.405-439. 1985.

. Línguas brasileiras. Para o conhecimento das línguas indígenas. São Paulo: Loyola. 1986.

Macro-Jê. In DIXON, R.M.W.; AIKHENWALD, A. Y. (orgs.). The Amazonian Languages. Cambridge: Cambridge University Press. p. 165-206. 1999.

'Ge-Pano-Karib' x 'Jê-Tupi-Karib': sobre relaciones lingüísticas prehistóricas em Sudamérica. Actas del I Congreso de Lenguas Indígenas de Sudamérica. Lima: Universidad Ricardo Palma, t.1, p.95-104. 2000a.

Flexão relacional no tronco Macro-Jê. Boletim da Associação Brasileira de Lingüística. v. 25, p. 219-231, 2000 b. 
. "Para o estudo histórico-comparativo das línguas Jê. In: L. dos Santos e I. Pontes (orgs.). Línguas Jê: estudos vários. Londrina: Ed UEL, 2002.

RODRIGUES, Aryon Dall'Igna; CABRAL, Ana Suelly Arruda Câmara. Tupían. In CAMPBELL, Lyle, GRONDONA, Verónica (eds). The indigenous languages of South America: a comprehensive guide. Berlin: De Gruyter Mouton, 2012.

SANTOS, Silvio Coelho dos. Índios e brancos no sul do Brasil: a dramática experiência dos Xokleng. Florianópolis: Edeme, 1973.

SAPIR, Edward. Language. New York: Harcourt and Brace, 1949.

SAKEL, Jeanette \& EVERETT Daniel L. Linguistic fieldwork. Cambridge/New York: Cambridge University Press, 2012.

SCHACHTER, Paul. Parts-of-speech systems In: SHOPEN, Timothy (ed.). Language typology and syntactic description. Vol. I. Cambridge: Cambridge University Press, 1985.

URBAN, Greg. Ergativity and accusativity in Shokleng (Gê). International Journal of American Linguistics. v.51, n.2, p. 164-187. 1985.

URBAN, Greg. A model of Shokleng social reality. Thesis (Ph. D) University of Chicago, 1978.

VOGEL, Petra M. COMRIE, Bernard (eds.). Approaches to the typology of word classes. Berlin \& New York: Mouton de Gruyter, 2000.

WIESEMANN, Ursula. Phonologische und grammatische struktur der kaingáng sprache. The Hague, Paris: Mouton, 1969. 


\section{ANEXO}

\section{KLẼDO ÓG KAPÓ JÓ KABEL}

TRANSCRIÇÃO: NANBLÁ GAKRAN

klẽdo óg kapó te vũ klẽ tól tóg ge ló kapó mũ nom.masc 3PP sair Espec MS montanha duro DEMON assim POSP sair PERF

'a saída dos Klẽdo [ocorreu] para fora de uma montanha como estas [montanha]'

kũ, vãgdjó tõ Pazi vũ gó tóg te ve jé kakutãdẽg vén mũ $\mathrm{Cj}$ chefe TRANS nom. masc MS terra DEMON Espec ver POSP sair primeiro PERF 'assim, o chefe Pazi foi o primeiro que saiu para ver esta terra'

ẽ kapó te jé óg, klãm te mõ kónhka pãn tõ txun ke te CORR sair Espec POSP 3PP embaixo Espec POSP céu pé TRANS fincar PROSP Espec ki nõ kégke mũ POSP estar HAB PERF

'aqueles que estavam para sair permaneciam embaixo do horizonte (lit.: onde o pé do céu apóia na terra)'

óg tõ kónhka pãn tõ txun te ki nõ te jãgló, Pazi te 3PP TRANS céu pé TRANS fincar Espec POSP estar Espec nisso nom. masc espec gó tóg te ve jé ũ te óg jo kataply mũ. terra DEMON Espec ver POSP outro Espec 3PP POSP subir PERF

'enquanto os outros permaneciam no horizonte, Pazi subiu antes para ver esta terra'

ẽ tõ gó ve te kũ ta, vãtxika ũ te óg mõ CORR TRANS terra ver espec Cj 3PSM de volta outro Espec 3PP POSP $\tan$ jé tẽ mũ. 
contar POSP ir PERF

'então, ao ver a terra, ele voltou para contar aos outros'

kũ ta, ẽ tavi te kũ, ũ te óg mõ: tóg

$\mathrm{Cj}$ 3PSM CORR chegar Espec $\mathrm{Cj}$ outro Espec 3PSM POSP DEMON

te tá vũ gó te u tẽ', ke ta mũ

Espec POSP MS terra Espec outro IMPERF PROSP 3PSM PERF

'então ele, ao chegar, [disse] para os outros: lá tem terra boa, disse'

ẽ tõ like kól te kũ ta, vãtxika óg jó ãmẽn te han CORR TRANS POSP depois Espec Cj 3PSM de novo 3PP POSP caminho Espec fazer kataply mũ ẽ katazyl te jé ta ũ te óg mõ: ẽnh dju subir PERF CORR subir Espec POSP 3PP outro Espec 3PP POSP 1P POSP kajapã, jé nũ mẽ a jo ãmẽn te han tẽg, ge mũ subir POSP 1P todos 2P POSP caminho Espec fazer ir PROSP PERF

'então, depois [que falou ] disso, subiu de volta na frente deles para fazer caminho, mas antes de ir subindo [disse] aos outros: subam atrás de mim, assim eu vou na frente de vocês fazendo o caminho, disse'

ãmẽn te han kataply, óg mõ gó kulég kataply jã, gó tóg caminho Espec fazer subir 3PP POSP terra roçar subir estar terra DEMON te ki vyn ke mũ Espec POSP chegar PROSP PERF

'subiu fazendo o caminho, subiu roçando [o caminho] a terra para eles, assim alcançaram esta terra'

kũ ti tõ han katazyl te du vũ, vãgdjó tõ Txu tõ

Cj 3PSM RANS fazer subir Espec POSP MS chefe TRANS nom. masc TRANS

Txuvanh te ti du kataply mũ nom.masc Espec 3PSM POSP subir PERF 
'então o chefe Txu Txuvanh subiu logo atrás dele que ia fazendo o caminho [do Pazi]'

ũn tõ ti du kataply vén mũ ha vã, tóg ha vũ quem TRANS 3PSM POSP subir primeiro ir ENF ESTAT DEMON ENF MS

Pazi te du kataply mũ

nom. masc Espec POSP subir PERF

'[ele] era mesmo o primeiro que subiu logo atrás [do Pazi], 'este mesmo subiu atrás do Pazi'

ẽ tõ tól ki jun ge vén jó te ki óg nõ CORR TRANS fora POSP sair PROSP primeiro Retrosp Espec POSP 3PSM estar kũ ki ãgglag nõdẽ kégke mũ jãgló Pazi te ãmẽn te Cj POSP dançar estar HAB PERF mas nom. masc Espec caminho Espec han tẽ mũ fazer ir PERF

'os outros ficaram ali onde apareceram pela primeira vez, ficaram festejando por ali, enquanto isso Pazi foi fazendo o caminho'

gó kulég ta ẽ tõ gó ve te to taply jã, ki vyn terra roçar 3PSM CORR TRANS terra ver Espec POSP subir estar POSP chegr em cima ke mũ, mẽ ti txó jãgló óg ãgglag nõdẽ kégke mũ PROSP PERF por ali 3PSM indo nisso 3PP dançar estão HAB PERF

'ele foi roçando [caminho] até alcançar a terra que já tinha visto antes quando subira, enquanto ele permanecia [incursionando] por ali, eles continuavam festejando'

kũ jãgló ũn te óg vel ti du japly mũ, kũ Txu tõ $\mathrm{Cj}$ nisso alguém Espec 3PP de novo 3PSM POSP subir PERF $\mathrm{Cj}$ nom masc TRANS Txuvanh te ũn tavig mũ te jyjy te jé óg jãnkle nom. masc Espec alguém chegar PERF Espec nome Espec POSP 3PP perguntar kégke mũ HAB PERF 
'entretanto, os outros foram subindo novamente atrás dele, então Txu Txuvanh perguntava o nome daqueles que estavam chegando'

kũ ta óg mõ: ẽnh blé glé jé kalá kégke jã ha vũ,

Cj 3PSM 3PP POSP 1PP POSP dançar POSP entrar HAB estar ENF MS Zágpopẽ te vũ ti du kataply mũ nom. masc Espec MS 3PSM POSP subir PERF

'então ele falava para eles: entre para dançar comigo', enquanto isso, Zágpopẽ̃ subiu atrás dele'

ẽ tõ ki jun ge vén jó te ki óg ãgglag nõ, CORR TRANS POSP aparecer PROSP primeiro RETROS Espec POSP 3PP dançar estar ẽ tõ tól ki jun ge vén jó te ki óg glé nõ CORR TRANS duro POSP aparecer PROSP primeiro RETROS Espec POSP 3PP dançar estar nõ jãgló, vãgdjó tõ Zágpopẽ te óg du kataply mũ, ẽ jógtá estar nisso chefe TRANS nom. masc Espec 3PP POSP subir PERF CORR mulheres te óg blé, ti kánhka óg vã, óg ha jyjy vũ jógtá kégke mũ Espec 3PP POSP 3PSM parente 3PP ESTAT 3PP ENF nome MS mulheres HAB PER

'eles ficaram festejando ali onde havia aparecidos pela primeira vez e, enquanto estavam dançando ali onde haviam aparecido pela primeira vez, enquanto isso o chefe Zágpopẽ subiu atrás deles com suas parentes, elas eram [ mulheres] parentes dele, eram chamadas de 'jógtá'

kũ ta ti mõ: ũn tõ kónhgág nũ vã? a jyjy te Cj 3PSM 3PSM POSP alguém TRANS homem quem ESTAT 2P nome Espec hã like tẽ?", ke mũ ló ta: ẽnh jyjy vũ Zágpopẽ ENF POSP IMPERF PROSP PERF POSP 3PSM 1PP nome MS nom. masc tõ Pata ke tẽ', ke mũ trans nom. masc PROSP IMPERF PROSP PERF

'então [Txu disse] para [Zágpopẽ]: quem é este homem? Como é seu nome? nisso ele [Zágpopẽ] respondeu: meu nome é Zágpopẽ Pata, falou’ 
mũ ló ta mã kũ ti mõ: vãgdjó tõ Zágpopẽ tõ Pata!

PERF POSP 3PSM ouvir Cj 3PSM POSP chefe TRANS nom. masc TRANS nom.masc

Pata! vãtxõ mã ke kũ ẽnh blé glé jé kala!', ke ta ti

nom. masc Refl 2P PROSP Cj 1P POSP dançar POSP entrar PROSP 3PSM 3PSM

tẽg te dun mũ

ir Espec POSP PERF

'ao ouvir isso, ele [Txu Txuvanh] disse para ele: chefe Zágpopẽ Pata! agora que você disse seu nome, venha dançar comigo!, disse por trás daquele [Zágpopẽ] que estava indo’

ti tõ ẽ mõ like te kũ, mã kũ ta, ti to kala kũ

3PSM TRANS CORR POSP POSP TRANS Cj ouvir Cj 3PSM 3PSM POSP entrar Cj

ti blé glé mũ

3PSM POSP dançando PERF

'[Txu] tendo dito assim para ele [Zágpopẽ] ao ouvir isso ele entrou e dançou com [Txu]'

ti tõ ẽ blé glé há ve kũ ti tõ, ti jẽgglam ló, 3PSM TRANS CORR POSP dançar bem ver Cj 3PSM TRANS 3PSM observar POSP ti jógtá te óg kutxej tũ, ti blé glé nõdẽ, kul tũ óg 3PSM mulheres TRANS 3PP roupa Neg 3PSM POSP dançar estão roupa Neg 3PP ti blé nõdẽ, ẽ kul tũ te kũ óg zuvág zál tõ vãnhbegzẽn 3PSM POSP estão CORR roupa Neg Espec Cj 3PP nom. anim casco TRANS coberta kũ ti blé glé nõdẽ

Cj 3PSM POSP dançar estão

'[Txu Txuvanh] ao ver que ele [Zágpopẽ] estava dançando bem com consigo, passou a constatar que os parentes [mulheres] dele [Zágpopẽ] estavam descobertas dançando com ele, elas estavam sem roupa com ele, estando sem roupa, com as partes cobertas com casca de zuvág, estavam dançando com ele'

ti jógtá óg kutxej tũ há ẽ tõ ve te kũ ta ti mõ: 3PSM mulher 3PP roupa Neg melhor CORR TRANS ver Espec Cj 3PSM 3PSM POSP vãgdjó tõ Zágpopẽ tõ Pata de jé mã, ẽ txõ vãgdjan tũ 
chefe TRANS nom. masc TRANS nom.mesc porque POSP 2P CORR TRANS festeja Neg

ve kũ mã, a kutxej tũ hã jãgló mã, ẽnh blé glé jé kala mũ ver $\mathrm{Cj} 2 \mathrm{P} 2 \mathrm{P}$ roupa Neg ENF mas $2 \mathrm{P}$ 1P POSP dançar POSP entrar PERF ke ta ti mõ mũ

PROSP 3PSM 3PSM POSP PERF

'ao ver que as jógtá [mulheres] dele estavam descobertas, [Txu Txuvanh] disse para ele: chefe Zágpopẽ Pata! Por que você entrou para dançar comigo, vendo que me desautoriza [estando] suas mulheres nuas! disse para ele'

kũ ta, ẽ hã tõ tól ki jun ke vén mũ ka, Cj 3PSM CORR ENF TRANS fora POSP aparecer PROSP primeiro PERF POSP ẽ kutxej tõ kul kupli gé jé tẽ mũ, kũ ta, gég CORR roupa TRANS roupa branca pegar (pl.) POSP ir PERF Cj 3PSM pegar (pl.) katẽ kũ Zágpopẽ te klẽ lẽg mũ vir $\quad \mathrm{Cj}$ nom. masc. Espec encima jogar PERF

e ele [Txu Txuvanh] como foi primeiro que havia emergido da terra, então foi buscar suas roupas [panos] brancos de cobrir, quando trouxe largou sobre Zágpopẽ'

ẽ tõ ti blé glé kánãtẽg te kũ ta, ti klẽ lẽnh kũ CORR TRANS 3PSM POSP dançar caminhando Espec Cj 3PSM 3PSM ensima jogar Cj ti mõ: vãgdjó tõ Zágpopẽ tõ Paté! vãtxõ mã, tóg gen 3PSM POSP chefe TRANS nom. masc TRANS nom. masc Refl 2P DEMON agora kũ ẽnh kul kupli tóg tõ mã, a jógtá, óg pegzẽn kũ mã, ẽnh blé $\mathrm{Cj} 1 \mathrm{P}$ roupa roupa DEMON TRANS $2 \mathrm{P} 2 \mathrm{P}$ mulher $3 \mathrm{PP}$ coberta $\mathrm{Cj} 2 \mathrm{P} \quad 1 \mathrm{P}$ POSP glé! de jé mã, ẽ txõ vãgdjan tũ ve kũ mã, a jógtá óg dançar porque POSP $2 \mathrm{P}$ CORR TRANS festejar Net ver $\mathrm{Cj} 2 \mathrm{P} 2 \mathrm{P}$ mulheres 3PP kutxej tũ ha jãgló ẽnh blé glé mũ!', ke ta ti mõ mũ kul Neg ENF mas 1P POSP dançar PERF PROSP 3PSM 3PSM POSP PERF

'ele [Zágpopẽ] estava circulava dançando com ele [Txu Txuvanh], largando-as [roupas] sobre ele, disse: chefe Zágpopẽ Pata! faça agora, com estas minhas roupas brancas, você vista as 
tuas mulheres e dance comigo! Por que dançou comigo estando nuas as suas mulheres descobertas, vendo que [assim] estás me desrespeitando!', [Txu Txuvanh] disse para ele' kũ ta vãha ti blé glé mũ, ti blé vig mũ ke jã

Cj 3PSM agora 3PSM POSP dançar PERF 3PSM POSP sempre ir PROSP estar ta, ẽ tõ djag ke te kũ ta, nũl mũ 3PSM CORR TRANS bêbado PROSP Espec Cj 3PSM dormir PERF

'então [Zágpopẽ] finalmente dançou com ele [Txu Txuvanh], ficaram [dançando] juntos e [Zágpopẽ Pata] ao ficar bêbado, dormiu'

ti tõ djag ke kũ, ti nũgban te mõ óg, ẽ kul te 3PSM TRANS bêbado PROSP Cj 3PSM adormecido Espec POSP 3PP CORR roupa Espec tõ ti mõ vin mũ te pigdju mũ, kũ óg ti nũgban te TRANS 3PSM POSP dar PERF Espec roubar PERF Cj 3PP 3PSM adormecido Espec mõ ti kul te gég mũ jó tẽ POSP 3PSM roupa Espec pegar ir RETROSP IMPERF

'enquanto que ele [Zágpopẽ] estava bêbado e aproveitando que dormia profundamente, eles roubaram as roupas que [Txu Txuvanh] deu para ele, levaram todas as roupas dele embora aproveitando que ele dormia profundamente'

te kũ, ti lẽl ló, ti kul te tũ tẽ, ti jógtá te Espec Cj 3PSM acordar POSP 3PSM roupa Espec Neg IMPERF 3PSM mulheres Espec óg blé vel kágkól kan jó tẽ, kũ ta ẽ tõ ve 3PP POSP também sumir terminado PROSP IMPERF Cj 3PSM CORR TRANS ver te kũ to jũ mũ Espec Cj POSP brabo PERF

'quando ele [Zágpopẽ] acordou, suas roupas haviam desaparecido, todas as suas mulheres haviam também sumido junto com eles e ele, vendo isso, ficou furioso'

[Zágpopẽ Pata] to jũ kũ ta óg mõ: a tõ ẽnh zõm te mũ nã nom. masc. $\quad$ POSP brabo Cj 3PSM 3PP POSP 2P TRANS 1P chorar Espec PERF 1PP 
ló mã va, a klã kágpó ja tũ kũ mã, a kággó kũ kágtã le POSP 2P agora 2P filho nascer PROSP Neg $\mathrm{Cj} 2 \mathrm{P} \quad 2 \mathrm{P}$ adoecer $(\mathrm{pl}) \mathrm{Cj}$ morrer decer ve!, ke ta mũ, ti tõ óg jo vanh vã, óg tõ ẽ ver PROSP 3PSM PERF 3PSM TRANS 3PP POSP rogar ESTAT 3PP TRAN CORR kóggó kũ ty ke jé ti tõ óg mõ ke vã doente $\mathrm{Cj}$ morrer PROSP POSP 3PSM TRANS 3PP POSP PROSP ESTAT

'ao ficar bravo [Zágpopẽ Pata] disse para eles: já que vocês me fizeram chorar, por isso agora não conseguirão parir seus filhos e com isso adoecerão e assim começarão a morrer!, disse, ele estava os amaldiçoando, dizia para eles que ao adoecer, eles iriam morrendo [um por um]'

ẽ tõ óg jo vanh kól te kũ ta, ẽ mãg tõ pénẽ ban CORR TRANS 3PP POSP preve depois Espec Cj 3PSM CORR criação TRANS jabuti pegar jé tẽ mũ, pénẽ te ban jé tẽ kũ ta, ẽ tõ ti bó katẽg POSP ir PERF jabuti Espec pegar POSP ir Cj 3PSM CORR TRANS 3PSM trouxe vir te kũ ta, óg jógglag nõ te ki ta, óg klãm pénẽ te zun Espec Cj 3PSM 3PP dançar estar Espec POSP 3PSM 3PP embaixo jabuti Espec jogar mũ, kũ ta óg mõ: vãtxõ jé, a tõ mẽ ẽnh zõm tẽ ló jé PERF Cj 3PSM 3PP POSP Refl POSP 2P TRANS por tudo 1P chorar ir POSP POSP ẽnh mãg tõ pénẽ tóg jé, a nũn kulég hũ jé mã, kággó $1 \mathrm{P}$ criação TRANS jabuti DEMON POSP $2 \mathrm{P}$ dormir pouco $\mathrm{Cj}$ POSP $2 \mathrm{P}$ doente $(\mathrm{pl})$ kũ kágtã le ve!, ke ta mũ $\mathrm{Cj}$ morrer decer ver PROSP 3PSM PERF

'depois de ele os ter amaldiçoado, foi buscar sua tartaruga de estimação, tendo ido pegar a tartaruga, ao trazê-la ali onde estavam festejando, a jogou por baixo deles, então ele [Zágpopẽ] disse para eles: que seja, já que vocês me fizeram chorar, esta minha tartaruga de estimação fará vocês terem vida curta e aí ficando doentes, [vocês] começarão a morrer! ele disse'

ti tõ óg jo vanh ha vã, ẽ tõ óg jo vanh kól te 3PSM TRANS 3PP POSP preve ENF ESTAT CORR TRANS 3PP POSP preve depois Espec kũ ta tẽ mũ, kũ óg, kól te kũ ãmẽn te mẽ glé le $\mathrm{Cj}$ 3PSM ir PERF Cj 3PP depois Espec $\mathrm{Cj}$ caminho Espec por tudo dançar decer 
mũ, glé le ke jã óg, ãgglan jó ũ nã ki hun ge kũ ãgglan PERF dancçar decer PROSP estar 3PP dançar POSP outro 1PP POSP parar PROSP Cj dançar ban mũ de novo PERF

'ele estava mesmo os amaldiçoando, logo depois de amaldiçoá-los, [Zágpopẽ] foi embora, depois disso, eles continuaram indo pelo caminho dançando, eles iam dançando e pararam num lugar que [os outros] haviam festejado, festejaram novamente'

ãgglan jó ũ ki óg ãgglag nõdẽ jãgló, óg dun jẽl katxin ẽ dançar POSP outro POSP 3PP dançar estão nisso 3PP POSP criança pequeno CORR do tugzẽl bág tõ vãnh klẽ zi kũ, óg jógglag nõ te nã flecha feixe grande TRANS REFL encima deitado $\mathrm{Cj}$ 3PP festejar estão Espec 1PP ki kala mũ POSP entrar PERF

'festejavam num dos lugares que [os outros] já haviam festejado, enquanto isso. veio atrás deles uma criança pequena levando sobre si uma grande amarra de flechas e entrou ali onde festejavam'

kũ vãgdjó tõ Txu tõ Txuvanh te, Zágpopẽ te mõ:

$\mathrm{Cj}$ chefe TRANS nom. masc TRANS nom masc Espec nom. masc Espec POSP hã like jé, jẽl katxin tóg nã nũ, ẽ do tugzẽl bág ENF POSP POSP criança pequeno DEMON 1PP INTERR CORR flecha feixe grande tóg te nã bó katéle mũ? ke ta ti mõ mũ DEMON Espec 1PP trazer descer PERF PROSP 3PSM 3PSM POSP PERF

'então o chefe Txu Txuvanh perguntou para o Zágpopẽ: para que será que esta criança pequena trouxe esta amarra grande de flechas?', perguntando assim para ele'

jẽl te ẽ katxin hã jãgló, ẽ hã vãnhkaju kũ, mã kũ ti mõ: criança Espec CORR pequeno ENF nisso CORR ENF vangloriar Cj 2P Cj 3PSM POSP Ivo! Ivo ẽ txõ ẽnh jógtá kapóm jó jé, ẽ txõ ẽnh do Neg Neg CORR TRANS 1P mulher sair(pl.) PROSP POSP CORR TRANS 1P flecha 
tugzẽl bág tóg te bó katéle vã! ke ta ti mõ mũ feixe grande DEMON Espec trazer descer ESTAT PROSP 3PSM 3PSM POSP PERF 'a criança, mesmo sendo pequena, se vangloriando, ao ouvir isso disse para ele: não, não! estou trazendo esta minha grande amarra de flechas, porque minhas jógtá [mulheres] foram soltas!', disse para ele'

‘ẽ katxin hã jãgló, ẽ hã ẽ jógy mã kũ ti tõ, ti blé CORR pequeno ENF nisso CORR ENF CORR forte $2 \mathrm{P}$ Cj 3PSM TRANS 3PSM POSP vãnh kóto ti mõ vẽ vã, ti kũ ta, mã kũ, ti mõ vẽ Refl contra 3PSM POSP falar ESTAT 3PSM Cj 3PSM 2P Cj 3PSM POSP falar ban tũ tẽ novamente Neg IMPERF

'mesmo sendo pequeno, ao se sentir corajoso, confrontou com ele [Txu Txuvanh], então ao ouvir isso, [Txu Txuvanh] não disse mais nada para ele'

kũ óg, kól te kũ ãgglag le ban mũ, óg jógglag le te

$\mathrm{Cj}$ 3PP depois Espec $\mathrm{Cj}$ dançar descer de novo PERF 3PSM festejando descer Espec

kũ, óg blé le mũ

Cj 3PP POSP descer PERF

'depois disso, novamente eles continuaram a festejar, e em seguida eles foram junto os demais festejando [pelo caminho]'

jãgló Pazi jug te ẽ tõ, ãgdo tá ẽ katẽg te kũ, nisso nom. masc pai Espec CORR TRANS atrás POSPCORR vir Espec $\mathrm{Cj}$ kójunh klé ve mũ za te vég mũ, jãgló kójunh klã te periquito toca ver PERF conhecido Espec ver PERF mas periquito filho Espec ti klé te ki togtoj kũ tóg ké ki nõdẽ 3PSM toca Espec POSP recém nascidos $\mathrm{Cj}$ DEMON agora POSP estão

'enquanto isso, o pai de Pazi, que vinha atrás deles, viu o ninho de periquitos que estava sempre à vista. E naquele momento os filhotes do periquito estavam no ninho já estava fora da casca' 
jãgló ũ te óg ẽ tõ vég gégke kũ, klãm mũ kégke mũ, ẽ mas outros Espec 3PP CORR TRANS ver HAB CJ embaixo ir HAB PERF CORR tõ to tazyl kũ, to kutã to ãklég gégke kũ óg jógzẽ vã TRANS POSP subir Cj POSP cair POSP pensar HAB Cj 3PP maneira ESTAT

'sempre quando os outros passavam por ali embaixo, viam sempre, mas tinham medo de subir até pra ver, porque tinha pressentimento que poderia cair'

jãgló Pazi jug te, ẽ tõ óg blé ti blé katéle te kũ ve mas nom.masc pai Espec CORR TRANS 3PSM POSP 3PSM POSP descer Espec Cj ver mũ ẽ tõ e te kũ ta, to taply mũ, ẽ tõ ve te kũ PERF CORR TRANS ver Espec Cj 3PSM POSP subir PERF CORR TRANS ver Espec Cj ta, to taply mũ, mlũl kym kũ ta, kógdje kũ to kuzẽn kũ ka, 3PSM POSP subir PERF cipó cortar Cj 3PSM amarrar Cj POSP amarrar Cj POSP to taply mũ, ti tõ, to taply hã mõ, mlũl te ẽ glóg ka POSP subir PERF 3PSM TRANS POSP subir ENF POSP cipó Espec CORR nó POSP blal ke mũ, te kũ ta, kutã kũ ty mũ quebrar PROSP PERF Espec $\mathrm{Cj}$ 3PSM cair $\mathrm{Cj}$ morrer PERF

'entretanto, o pai de Pazi, ao descer junto com os outros atrás, ele viu, e ao vê-lo, subiu, cortando um cipó, amarrou fazendo um laço e subiu, [mas] enquanto estava subindo, o nó do cipó rompeu, então ele caiu e ao cair, morreu'

ti tel te kũ óg, ti kabén mũ, mã kũ óg ti to: de kũ 3PSM morrer Espec Cj 3PP 3PSM contar PERF ouvir Cj 3PP 3PSM POSP como Cj kũ ti tel nũ vã?, ke mũ, mũ ló óg ti to: kójunh Cj 3PSM morrer 1P ESTAT PROSP PERF PERF POSP 3PP 3PSM POSP periquito klé ve mũ za tõ ãmẽn klẽ nẽ ta to, ti tazyl ninho ver PERF frequente TRANS caminho encima estar 3PSM POSP 3PSM subir kũ to kutã kũ tel vã!, ke mũ, óg kutã kũ ty kégke tóg $\mathrm{Cj}$ POSP cair $\mathrm{Cj}$ morrer ESTAT PROSP PERF 3PP cair CJ morrer HAB DEMON ti tõ óg jo jógzẽ vén hã vã 3PSM TRANS 3PP POSP jeito primeiro ENF ESTAT 
'quando ele morreu, deram a notícia [da sua morte], ao ouvir perguntaram: de que ele morreu?, então disseram: por causa daquele ninho de periquito que ficava sobre o caminho, ele subiu até lá, caiu e morreu!, esta foi a primeira morte e a partir deste fato, todos que caíssem iriam morrer'

jãgló óg, ẽ glé jó ũ ki, goj bág zyl ki glé nisso 3PP CORR dançar PROSP outro POSP água grande beirada POSP dançar nõdẽ, goj bág zyl te mẽ óg jógglag nõdẽ kégke estão água grande beirada Espec por tudo 3PSM festejando estão HAB mũ, goj bág zyl te mẽ glé nõdẽ kégke jãgló, Vãjẽky PERF grande beirada Espec Espec por tudo dançar estão HAB nisso nom masc te katẽ mũ

Espc vir PERF

'enquanto isso, eles estavam dançando na beira do riozão, a onde [os outros] já haviam dançado, pela beira do riozão eles ficaram ali festejando. Enquanto eles que eles estavam dançando pela beira do riozão, o Vãjẽky chegou'

ẽ katẽg te kũ, Vãjẽky te goj bág zyl te ló kagklo CORR vir Espec $\mathrm{Cj}$ nom masc Espec água grande beirada Especc POSP peixe pénũ jé la mũ, kũ ta goj bág zyl ka kagklo jé kyl atirar POSP entrar PERF Cj 3PSM água grande beirada POSP peixe POSP gritar jã, ti tõ kagklo jé kyl mũ jãgló, ti klãm volá tũlo esta 3PSM TRANS peixe POSP gritar PERF nisso, 3PSM embaixo nom. peixe trato ko mũ, kũ ta, volá te pénũg mũ, ẽ tõ pénũ te kũ comer PERF Cj 3PSM nom. peixe Espec atirar PERF CORR TRANS atirar Espec $\mathrm{Cj}$ ta bó katẽ mũ 3PSM trazer vir PERF

'ao chegar, Vãjẽky se aproximou da beira do riozão para pescar, então ele, na beira do riozão, ficou chamando os peixes, enquanto que ele chamava os peixes, o peixe volá comeu o graveto (isca), então ele flechou o volá, e depois de acertá-lo, pegou e o trouxe' 
ẽ tõ volá pénũ te bó katẽ kũ ta, goj bág zyl

CORR TRANS nom. peixe atirar Espec trazer vir Cj 3PSM água grande beirada ka ẽ tõ klágnẽ jo ẽn jã ti to te ka ta POSP CORR TRANS carne de caça POSP casa estar 3PSM POSP Espec POSP 3PSM txag mũ, ka txag kól te kũ ta, óg blé ãgglan jé tẽg pendurar PERF POSP pendurar depois Espec Cj 3PSM 3PP POSP festejar POSP ir ban mũ de novo PERF

'ao trazer o volá pescado, ele o pendurou no meio da casa que é próprio para o depósito de carne, que estava ali na beirada do riozão, depois de deixar ali pendurado, ele foi festejar novamente com eles [os parentes]'

ti tõ óg blé glé kánãtẽg jãgló Pazi te ẽ jãn há 3PSM TRANS 3PP POSP dançar andando nisso nom. masc Espec CORR comida bem to, ẽ jug tõ kójunh klé ve mũ za to tazyl kũ, kutã POSP CORR pai TRANS periquito ninho ver PERF conhecido POSP subir $\mathrm{Cj}$ cair kũ, ty mũ te kũ, hã to ẽ katẽg te kũ ti tõ $\mathrm{Cj}$ morrer PERF Espec Cj ENF POSP CORR vir Espec Cj 3PSM TRANS volá pénũ te ko mũ, ti tánh há ló ko mũ nom. peixe atirar Espec comer PERF 3PSM cru inteiro POSP comer PERF

'enquanto ele circulava dançando com os outros [parentes], Pazi, por ser guloso, quando chegou, comeu o volá pescado, o comeu mesmo estando cru, por ser assim, seu pai quando viu o ninho de periquitos que estava à vista, tentou subir, mas caiu e morreu'

kũ ti tõ ve jé katẽg jãgló ti tõ volá pénũ te tũ Cj 3PSM TRANS ver POSP vir mas 3PSM TRANS nom. peixe atirar Espec Neg tẽ kũ ti tõ zé vãnkle jãgló óg ti to: Pazi vũ ko IMPERF Cj 3PSM TRANS POSP perguntar nisso 3PP 3PSM POSP nom.masc MS comer mũ! ke mũ PERF PROSP PERF 
'então ele [Vãjẽky] quando voltou para vê-lo, o volá pescado não estava mais ali, e ele perguntou sobre [o acontecido], os outros disseram: o Pazi comeu!'

Pazi tõ ko óg tõ tan te kũ ta, mã kũ ti mõ: nom.masc TRANS comer 3PP TRANS contar Espec Cj 3PSM 2P Cj 3PSM POSP Pazi! hã tõ vé! jãn há to, a jug tõ kójunh klé ve nom. masc ENF TRANS ver comida bem POSP 2P pai TRANS periquito toca ver mũ za to kutã kũ ty mũ hã kũ mã, ẽnh jókle tõ PERF conhecido POSP cair $\mathrm{Cj}$ morrer PERF ENF $\mathrm{Cj}$ 2P $1 \mathrm{P}$ caça TRANS volá kóto ko kan mũ! ke ta ti mõ mũ nom peixe contra comer tudo PERF POSP 3PSM 3PSM POSP PERF

'quando contaram que Pazi foi que comeu, ele [Vãjẽky ] disse para ele: Pazi! só podia ser! por você ser assim comilão o teu pai caiu e morreu, por causa do ninho de periquito que estava à vista, [e agora] você devorou todo o minha caça volá!', disse para ele'

ẽ tõ like kól te kũ ta, vãtxika ãmẽn te ki ti CORR TRANS POSP depois Espec Cj 3PSM de novo aminho Espec POSP 3PSM jãnãg mũ, kũ ta tẽ mũ, kũ óg ki ãgglag nõdẽ kégke mũ mandar PERF Cj 3PSM ir PERF Cj 3PP POSP dançar estão HAB PERF

'depois de ter dito isso, ele [Vãjẽky ] o mandou embora de volta pelo caminho, então [Pazi] foi embora, e eles continuaram festejando ali'

óg jógglag nõ, vãnh klẽ avanh ló, Pazi tõ óg klẽ tũlo 3PP dançar estar Refl encima olhar POSP nom. masc TRANS 3PP encima pilar há jãg jã, kũ óg tõ, vãnh klẽ avanh hã mõ óg, tũlo há bem colocar estar $\mathrm{Cj}$ 3PP TRANS Refl encima olhar ENF POSP 3PP pilar bem tõ, Pazi tõ mẽ ẽ klẽ zãg te vég mũ, jãgló TRANS nom. masc TRANS por tudo CORR encima colocar Espec ver PERF nisso óg tõ, tóg ké Pazi jãnã jó tẽ 3PP TRANS DEMON Prosp nom. masc mandar PROSP IMPERF 
'eles permaneceram festejando ali e quando olharam para cima, viram que Pazi havia colocado sobre eles um pilar [vara forte] e eles, ao olharem sobre si, viram o pilar que Pazi colocou sobre eles, naquele momento eles já tinham mandado o Pazi embora’

kũ óg, jé dén tũg nõ ke jã, ẽ tõ zág tej gõn Cj 3PP POSP algo Neg estar PROSP estar CORR TRANS colocar comprido derrubar jé vãjõ kugzyn mũ, kũ óg ẽ tõ gõn te kũ to kózan POSP Refl chamar PERF Cj 3PP CORR TRANS derrubar Espec Cj POSP modelar mũ, ẽ tõ kózan te kũ kóto zãg mũ PERF CORR TRANS modelar Espec $\mathrm{Cj}$ apar colocar PERF

'eles não tendo algo para o pilar naquele momento, se convocaram para derrubar um broto de araucária e eles, ao derrubá-lo, o emparelharam com o pilar, colocaram do outro lado para emparelhá-lo’

ẽ tõ kóto zãg te kũ óg, vaha vãnh klẽ ẽn mũ, vãnh CORR TRANS apar colocar Espec Cj 3PP agora Refl encima casa PERF Refl klẽ ẽn ge jã, ẽ nẽn bág te kutxénh kan dẽ mũ encima casa PROSP estar CORR casa grande Espec fechada pronto ir PERF

'depois de colocar outro por cima e emparelhado eles finalmente construíram a casa, eles terminaram de cobrir por cima do que seria a sua grande moradia'

jãgló kónhgág kale jógy mã kũ óg, ẽ tõ kónhgág kómãg hũ nisso homem descer muito ouvir $\mathrm{Cj} 3 \mathrm{PP}$ CORR TRANS homens medo $\mathrm{Cj}$ zé dén tũg nõ jã, ẽ tõ vãtxo vãju jé kujũnh han nõdẽ POSP algo Neg estar CORR TRANS Refl ritual POSP erva fazer estão kégke mũ hab PERF

'nisso ouvirem barulho de uma multidão de homens que estavam vindos e ficaram com medo, não tendo nada para se proteger e começaram a preparar o $k$ ujũnh ${ }^{30}$ para fazer o ritual para se proteger do perigo [e ver previsão]'

\footnotetext{
${ }^{30}$ Erva silvestre mascada em rituais para prever o futuro.
} 
óg tõ kujũnh te han nõdẽ jãgló, Pazi te vel vãtxika 3PP TRANS periquito Espec fazer estão nisso nom. masc Espec namente de volta katẽg ban mũ, kujũnh te han nõdẽ ke jã han kan dẽ mũ, vir de novo PERF erva Espec fazer estão PROSP estar han concluir ir PERF kũ óg vaha tõ vãtxo vãju mũ, jãgló Pazi te, óg tõ Cj 3PP agora TRANS Refl ritual PERF nisso nom masc Espec 3PP TRANS vãtxo vãju kujũnh tõ nõdẽ te mã kũ ta, óg ẽn ba te Refl ritual erva TRANS estão Espec 2P Cj 3PSM 3PP casa POSP Espec mẽ, óg pégjẽn tóg ge hunh kánãtẽ kégke mũ por tudo 3PP POSP DEMON PROSP assoviar andando HAB PERF

'enquanto estavam preparando o kujũnh, Pazi mais uma vez retornou, ficaram preparando o Kujũnh e ao terminar, então finalmente iniciaram o ritual, enquanto isso, ao ouvi-los realizando o ritual de prever o futuro [previsão] com kujũnh, Pazi zanzava por ali assobiando, os rodeando pelo pátio da casa deles'

kũ óg mãg nỹ ke jã, Vãjẽky te ti to kagkutãdẽ mũ Cj 3PP ouvir estar(pl.) PROSP estar nom. masc Espec 3PSM POSP sair PERF ẽ zãnka te tõ lónh ke kũ ta, Pazi te to kagkutãdẽ kũ CORR porta Espec TRANS abrir PROSP Cj 3PSM nom. masc Espec POSP sair $\mathrm{Cj}$ ti mõ: Pazi! ẽnh blé ã, ẽ txõ kónhgág kale jógy mã kũ 3PSM POSP nom. masc 1P POSP 2P CORR TRANS homem descer demais ouvir $\mathrm{Cj}$ vãtxo vãju jé, kujunh hal tóg tõ ẽnh blé vãtxo vãju jé Refl ritual POSP erva preparar DEMON TRANS 1P POSP Refl ritual POSP kala! ke ta ti mõ mũ entrar PROSP 3PSM 3PSM POSP PERF

'então eles ficaram escutando e Vãjẽky saiu para ter com ele, ao abrir a porta, saiu para fora e disse para o Pazi: entre comigo para fazer o ritual com este kujũnh preparado, pois escutei uma multidão de homens que estavam descendo!', [Vãjẽky] disse para ele [Pazi]'

mã kũ ta ti blé kala mũ, ti tõ ẽ blé kala te kũ ouvir Cj 3PSM 3PSM POSP entrar PERF 3PSM TRANS CORR POSP entrar Espec Cj 
ta, ti mõ kujũnh pe te zãg mũ, ti tõ ẽ mõ kujũnh 3PSM 3PSM POSP erva deluido Espec dar PERF 3PSM TRANS CORR POSP erva pe te zãg mũ jãgló ta, tõ tugtũ tẽ mũ, tõ tugtũ kũ deluida Espec dar ir nisso 3PSM TRANS vomitar ir PERF TRANS vomitar $\mathrm{Cj}$ ta tõ vãzãnka tõ jum ke mũ 3PSM TRANS expelir TRANS derramar PROSP PERF

'ao ouvir, [Pazi] entrou com ele, quando Pazi entrou com ele, [Vãjẽky] deu kujũnh diluído para [Pazi], quando ele deu kujũnh diluído ao [Pazi] foi logo vomitando, e ao vomitar expeliu tudo da boca'

ti tõ ẽ jo vanh jó ha kũ ti jógzẽn ge vã, 3PSM TRANS CORR POSP rogar RETROS ENF Cj 3PSM acontecer PROSP ESTAT kũ ta, ti tõ vãzãnka tõ jum ke te ve kũ, ti Cj 3PSM 3PSM TRANS expelir TRANS derramar PROSP Espec ver Cj 3PSM mõ: Pazi hã tõ vé a jãn há tõ, ẽnh jókle tõ POSP nom. masc ENF TRANS ver $2 \mathrm{P}$ comer bem TRANS 1P caça TRANS volá kóto ko kan mũ a kũ mã, ẽ txõ vãtxo vãju nom. peixe contra comer tudo PERF 2P CJ 2P CORR TRANS Refl ritual te tõ mã, tugtũ tẽ mũ! Pazi, a jãn há to a jug Espec TRANS 2P vomitar IMPERF PERF nom.masc 2P comer bem TRANS 2P pai tõ kójunh klé ve mũ za to tazyl kũ, mlũl tól tõ kuzẽn TRANS periquito toca ver PERF sempre POSP subir CJ cipó duro TRANS amarra kũ to tazyl kũ,ti tõ ẽ glóg ka blal ke kũ, ti Cj TRANS subir CJ 3PSM TRANS CORR junta POSP estralar PROSP Cj 3PSM kutã kũ ty mũ ha kũ mã, ẽ txõ, kónhgág kale jógy mã kũ, cair CJ morrer PERF ENF PERF 2P CORR TRANS homem descer ADV ouvir CJ 
ẽ txõ vãtxo vãju te tõ mã tugtũ te mũ!, ke ta CORR TRANS Refl ritual Espec TRANS 2P vomitar Espec PERF PROSP 3PSM ti mõ mũ 3PSM POSP PERF

Por [Vãjẽky] tê-lo amaldiçoado, tornou-se o carma dele, então [Vãjẽky], ao vê-lo expelir tudo da boca, disse: só podia ser Pazi ! Por você ser assim comilão e ter devorado toda minha caça volá (peixe), por isso agora você vomitou expelindo todo o kujũnh que preparei para fazer meu ritual (reza)!'

ẽ tõ ti mõ like kól te kũ ta, tól te ló ti CORR TRANS 3PSM POSP POSP depois Espec Cj 3PSM duro/fora Espec POSP 3PSM pazun mũ, óg tõ vãha ti zun tavẽn ha vã, kũ empurrar PERF 3PP TRANS agora 3PSM jogar/abandonar de verdade ENF ESTAT Cj Pazi te vãha vãtxõ tóg ké dé pãn mũ, kũ ta nome. masc Espec agora Refl DEMON agora algo estranho PERF Cj 3PSM ãmẽn tóg ge te mẽ, kutyg gégke kũ kyl kũ mẽ hunh nã caminho DEMON assim Espec todo escuri $\mathrm{HAB} \mathrm{Cj}$ gritar $\mathrm{Cj}$ todo assoviar $1 \mathrm{PP}$ bó (vó) kégke mũ, ẽ vãjõgdẽn te kũ ti jógzẽ ha vũ, amanhecer HAB PERF CORR transformar se Espec Cj 3PSM maneira ENF MS ãmẽn te mẽ kyl nã vó kégke mũ caminho Espec todo gritar 1PP amanhecer HAB PERF

'depois que falou isso para ele [Pazi], o empurrou para fora, agora eles estava abandonando ele de vez, agora Pazi se transformou em algo estranho, e nas noites ele [Pazi] andava gritando e assoviando noite inteira, por ele ter se transformado em algo estranho por isso que ele fazia isso, andava gritando pelo caminho noite inteira'

óg tõ ẽ zun te kũ ta, ãmẽn te mẽ kyl kũ, 3PP TRANS CORR jogar/abandonar Espec Cj 3PSM caminho Espec todo gritar $\mathrm{Cj}$ mẽ hunh kánãtẽ kégke jã ta, vãtxõ txãggõnh mũ, vãtxõ ta todo assoviar caminhando HAB estar 3PSM Refl pássaro PERF Refl 3PSM juggug tõ tátá mũ, juggug gỹnh ta li ta, vãtxõ ken mũ, gavião TRANS pequeno PERF gavião pequeno 3PSM parecido 3PSM Refl fazer PERF 
ẽ tõ vãtxõ tẽgtẽ te kũ ta, tóg ké gynh ha mõ CORR TRANS Refl gavião Espec Cj 3PSM DEMON agora pequeno ENF POSP kánãtẽ kégke mũ, kó lul nẽdo te ka ta: tá, tá, tá, tá, tá, tá, tá, caminha HAB PERF árvore seco encima Espec POSP 3PSM cantar do gavião ke jã kégke mũ, Pazi te, ti tõ, ti jo vanh ha PROSP estar HAB PERF, nom. masc Espec 3PSM TRANS 3PSM POSP amaldiçoar ENF kũ ti jógzẽ ha vũ, vãtxõ txãggõnh mũ Cj 3PSM maneira ENF MS Refl pássaro PERF

'quando eles o abandonaram [Pazi] andava pelo caminho gritando e assoviando, até que ele se transformou em passarinho, se transformou em gaviãozinho,

tóg ké ẽ tõ kokómã tánh, ko jó ha kũ ti DEMON agora CORR TRANS comida proibida crua comer RETROS ENF Cj 3PSM vãjõgdẽn ha vũ, vãtxõ, gyjun kũ tóg ké, vãtxõ txãggõnh mũ transformar se ENF MS Refl pequeno Cj DEMON agora Refl pássaro PERF tóg ké ẽ tõ kokómã tánh ko jó ha kũ ti DEMON agora CORR TRANS comida proibida crua comer RETROS ENF Cj 3PSM vãjõgdẽn ha vũ, vãtxõ, gyjun kũ tóg ké, vãtxõ txãggõnh mũ transformar se ENF MS Refl pequeno Cj DEMON agora Refl pássaro PERF 'porque ele comeu a comida [santa] proibida, aconteceu [tudo isso] depois que ele comeu esta comida, se transformando num espírito de animal, transformou se em espirito de animal.

ẽ tõ ti zun kól te kũ óg, ẽ nẽn bág CORR TRANS 3PSM jogar/abandonar depois Espec Cj 3PP CORR casa grande te la óg vãlen mũ, gó tóg ge te plun kũ, óg mẽ kum Espec POSP 3PP rancho PERF 3PP DEMON assim Espec varrer $\mathrm{Cj}$ 3PP todos carpi kũ, mẽ plun hón mũ, vãgdjó tõ Txu tõ Txuvanh te tõ $\mathrm{Cj}$ todos varrer bem PERF chefe TRANS nom. masc TRANS nom. masc Espec TRANS zy plun kan te kũ, vãha óg to kajã mũ, kũ ta ẽ tõ POSP varer terminar Espec $\mathrm{Cj}$ agora 3PP POSP vir PERF Cj 3PSM CORR TRANS óg blé glé kánãtẽg te kũ ta óg mõ: vãgdjó ũ jé ẽnh 3PP POSP dançar andando Espec Cj 3PSM 3PP POSP chefe alguém POSP 1P 
vãle tóg mẽ jóvig nẽm jé kala! ke ta mẽ óg mõ mũ rancho DEMON todos lutar deixar POSP entrar PROSP 3PSM todos 3PP POSP PERF

'depois que deixaram ele [Pazi], do lado [fora] da casa grande preparam outro lugar [com fogo], carpiram, limparam e varreram bem o terreiro, depois que o Txu Txuvanh limpou por tudo, agora eles vieram ali, e ele quando estava dançando com os outros [parentes] disse: um dos chefe poderia vir lutar por aqui! falou para eles'

vãgdjó tõ Txu tõ Txuvanh te, ẽ ha tõ óg jo chefe TRANS nome masc TRANS nome masc Espec CORR ENF TRANS 3PP POSP gó tóg te ki, tól ki jun ke vén ke mũ te kũ, terra DEMON Espec POSP fora POSP aparecer PROSP primeiro PROSP PERF Espec $\mathrm{Cj}$ ẽ ha óg mõ vẽ kégke vã, ti vẽ te mãg te vãgdjó CORR ENF 3PP POSP falar HAB ESTAT 3PSM falar Espec ouvir Espec chefe tõ Txu vũ to kagkutãde mũ, kũ óg ti javag nõdẽ, ha jãglo TRANS nom. masc MS POSP sair PERF Cj 3PP 3PSM atirar estar ENF nisso óg, ti pénũg tũ tẽ

3PP 3PSM acertar Neg IMPERF

'chefe Txu Txuval por ele ter emergido pela primeira vez nesta terra, ele mesmo falava para os outros, ouvindo ele falar o chefe Txu saiu para fora, e eles começaram atirar nele, mas ele não acertaram nele'

kũ óg ẽ tõ ti pénũg tũ te ve kũ dyg nõdẽ ke jã, vãgdjó Cj 3PP CORR TRANS 3PSM acertar Neg Espec ver Cj rir estar PROSP estar chefe tõ Txu tõ Txuvanh te ti mõ: vãgdjó tõ Txu! TRANS nom. masc TRANS nom. masc Espec 3PSM POSP chefe TRANS nom.masc vãtxõ jé tóg gen kũ a vãmõ óg jé a mõ do pipin kũ Refl POSP DEMON agora CJ 2P parente 3PP POSP 2P POSP flecha espalhar Cj mã, do lẽg le ve! ke ta ti mõ mũ 2P flecha jogar descer ver PROSP 3PSM 3PSM POSP PERF 
'quando viram que não acertaram nele começaram a rir, e o chefe Txu Txuvanh disse para ele: chefe Txu agora toda sua geração serão guerreiros e vão lutando conta seus inimigos! disse para ele'

ẽ tõ ti pénũg tũ te ve kũ óg tõ, ti tõ vãzãvej CORR TRANS 3PSM acertar Neg Espec ver Cj 3PP TRANS 3PSM TRANS rápido ti mõ tan vã, ẽ tõ ti pénũg tũ kũ,ti klen to, 3PSM POSP contar ESTAT CORR TRANS 3PSM acertar Neg Cj 3PSM escapar POSP ẽ tõ ti kágze kũ, ti tõ ti mõ vẽ vã CORR TRANS 3PSM agradar Cj 3PSM TRANS 3PSM POSP falar ESTAT

'por ver que não acertaram nele, considerou ele como um grande guerreiro, falou isso porque ficou muito feliz com ele'

ve kũ ta vel vãgdjó tõ Zágpopẽ jé kyl mũ, ti mõ ver $\mathrm{Cj}$ 3PSM novamente chefe TRANS nom. masc POSP gritar PERF 3PSM POSP ta: vãgdjó to Zágpopẽ! vãtxõ mã, ẽnh vãle mẽ jóvig nẽm jé 3PSM chefe TRANS nom. masc Refl 2P 1P rancho por ali lutar deixar POSP kala!, ke ta mũ entrar PROSP 3PSM PERF

'então novamente ele chamou o chefe Zágpopẽ, disse para ele: chefe Zágpopẽ! venha você lutar comigo no pátio de minha casa!'

kũ ta, mã kũ ti to kagkutãdẽ mũ, kũ ta me jóvig nẽm kánãtẽ, Cj 3PSM ouvir Cj 3PSM POSP sair PERF Cj 3PSM por ali lutar deixar andar jãgló óg, ti jãvag nõ jã, ẽ tõ ti pénũg tũ te ve nisso 3PP 3PSM atirar estão estar CORR TRANS 3PSM acertar Neg Espec ver kũ óg hun ge mũ, kũ óg dyg nõ jã ta, ti mõ: vãgdjó tõ Cj 3PP parar PROSP PERF Cj 3PP rir estão estar 3PSM 3PSM POSP chefe TRANS Zágpopẽ tõ Paté! vãtxõ jé a vãmõ jé, tóg gen kũ, a nom. masc TRANS nom. masc Refl POSP $2 \mathrm{P}$ parente POSP DEMON agora $\mathrm{Cj} 2 \mathrm{P}$ mõ do pipin kũ mã do lẽg le ve!, ke ta ti mõ mũ POSP flecha espalhar $\mathrm{Cj} 2 \mathrm{P}$ flecha pinchar descer ver PROSP 3PSM 3PSM POSP PERF 
'ouvindo isso ele [Zágpopẽ] saiu para fora, ai ele começo a lutar ali, começaram a tirar nele e quando viram que não acertaram nele, começaram a rir e depois ele [Txu Txuvanh] disse: chefe Zágpopẽ Paté! agora toda sua geração serão guerreiros e sempre vão lutando contra seus inimigos!'

kũ ta, kól te kũ kutãdẽ mũ, kũ óg vég te, Pazi te jé $\mathrm{Cj}$ 3PSM depois Espec $\mathrm{Cj}$ sair PERF Cj 3PP ver Espec nom. masc Espec POSP kyl mũ, Pazi te jé kyl kũ ta ti mõ: vãgdjó tõ gritar PERF nom. masc Espec POSP gritar Cj 3PSM 3PSM POSP chefe TRANS Pazi! Vãtxõ mã katẽg kũ, ẽnh vãle tóg mẽ jóvig nẽm jé nom. masc Refl 2P vir $\mathrm{Cj} 1 \mathrm{p}$ rancho DEMON por ali lutar deixar POSP kala!, ke ta mũ entrar PROSP 3PSM PERF

'depois disso ele saiu fora, e ao ver Pazi o chamou e ao chamar o Pazi ele disse para ele: chefe Pazi! venha até aqui para lutar comigo aqui no meu terreio!'

kũ ta, mãg te katẽ kũ mẽ jóvig mũ, kũ óg ti jãvag ha mõ, $\mathrm{Cj}$ 3PSM ouvir Espec vir $\mathrm{Cj}$ por ali lutar PERF Cj 3PP 3PSM atirar ENF POSP óg ti tõ hum ke mũ, ẽ tõ ti pénũ óg tõ tan 3PP 3PSM TRANS parar PROSP PERF CORR TRANS 3PSM acertar 3PP TRANS contar vã, ha vũ ti tõ hum ke mũ ESTAT ENF MS 3PSM TRANS parar PROSP PERF

'ao ouvir isso, ele veio até ali, então começaram a atirar nele, naquele primeiro instante acertaram nele'

kũ ta, ve kũ ti mõ: vãgdjó tõ Pazi! hã tõ vé! a

$\mathrm{Cj}$ 3PSM ver CJ 3PSM POSP chefe TRANS nom. masc talvez TRANS ver 2P tõ do jógkle vã vé!, ke ta ti mõ mũ, kũ ta, tól TRANS flecha escravo ESTAT ver PROSP 3PSM 3PSM POSP PERF Cj 3PSM fora te ló ti pazun mũ, kũ ta, ti tõ ẽ mõ like te kũ, Espec POSP 3PSM empurrar PERF Cj 3PSM 3PSM TRANS CORR POSP POSP Espec Cj 
mãg te tẽ mũ, kũ ta vãha tóg ké vãtxõ txãggõnh mũ ouvir Espec IMPERF PERF Cj 3PSM agora DEMON agora Refl pássaro PERF

'ao ver isso ele [chefe Txu Txuvanh] disse: chefe Pazi! agora eu sei que você é escravo de minha flecha! disse pra ele, então ele o empurrou para fora, ao ouvir oque ele falou para si, ele foi embora, agora é que ele se transformou definitivamente em passarinho'

kũ óg, kól te kũ hun ge mũ, hun ge kũ nõ jãgló mã $\mathrm{Cj}$ 3PP depois Espec $\mathrm{Cj}$ parar PROSP PERF parar PROSP $\mathrm{Cj}$ estão nisso ouvir mõ kónhgág kale jóggy te jã, kũ óg, mã kũ ãmẽn te ló POSP homens descer muito Espec estar $\mathrm{Cj}$ 3PP ouvir $\mathrm{Cj}$ caminho Espec POSP glé kale ló, Pazi tõ óg jo ãmẽn han téle jó dançar descer POSP nom. masc TRANS 3PP POSP caminho fazer descer RETROS te ló, zug há óg le jó tẽ kũ óg, vég te óg Espec POSP branco bem 3PP descer RETROS IMPERF Cj 3PP ver Espec 3PP du glé kale óg kale jó te ló, jãgló Mẽvo kómãg, POSP dançar descer 3PP descer RETROS Espec POSP mas nom.masc medo jógy te ti jómẽn tẽ, óg jómẽn te ki tõ zãg ADV Espec 3PSM caminho IMPERF 3PP caminho Espec POSP TRANS colocar em pé hũ nẽ $\mathrm{Cj}$ estar

'depois disso eles pararam, nisso ouviram barulhos de muitos homens que estavam vindo, então eles vieram descendo pelo caminho festejando pelo caminho que [Pazi $\left.{ }^{31}\right]$ tinha feito, tinha rastro decido de uns brancos, ao ver eles foram descendo festejando atrás deles, nisso eles viram outro caminho do Mẽvo considerado por eles perigoso que fazia encruzilhada com a deles'

jãgló zug há te óg ẽ kale te kũ, óg jómẽn tõ zãg mas branco bem Espec 3PP CORR descer Espec CJ 3PP caminho TRANS por em pé te ki, óg tõ nẽzénh kũ ta nẽ, kó tõ óg tõ ki Espec POSP 3PP TRANS fechar CJ 3PSM estar árvore TRANS 3PP TRANS POSP gõngõn kũ, tõ nẽzénh kũ ta tẽ

\footnotetext{
31 Veja este Pazi é um outro, não é o mesmo personagem que foi amaldiçoado falada anteriormente.
} 
derrubar $\mathrm{Cj}$ TRANS fechar $\mathrm{Cj}$ 3PSM IMPERF

'esses brancos quando vieram fecharam o caminho deles, derrubaram umas árvores e deixaram fechado'

kũ óg vég te glé kale mũ, óg glé kale jãgló, Dãnlám $\mathrm{Cj}$ 3PP ver Espec dançar descer PERF 3PP dançar descer nisso outro grupo óg kale jó, óg jómẽn te du katéle kũ óg mẽ glé kale 3PP descer RETROS 3PP caminho Espec POSP descer Cj 3PP por tudo dançar descer ha mõ, óg du zãmẽg mũ, ẽ tõ óg du zamẽ te kũ ta, ENF POSP 3PP POSP alcançar PERF CORR TRANS 3PP POSP alcançar Espec Cj 3PSM óg, mõ: ũn tõ kónhgág nũ vã?, ke ta óg mõ mũ, jãgló 3PP POSP quem TRANS homem 1P ESTAT PROSP 3PSM 3PP POSP PERF nisso óg, mãgóg vég kójã , to vẽ mã ka óg vég nỹ, kũ ta, óg 3PP ouvir 3PP ver em pé POSP falar ouvir POSP 3PP ver ficar (pl) Cj 3PSM 3PP tõ ẽ jãnkugmãn ve kũ, ẽ tõ óg to jũ kũ ãmẽn te TRANS CORR negar ver $\mathrm{Cj}$ CORR TRANS 3PP POSP brabo $\mathrm{Cj}$ caminho Espec nẽgke mõ, óg pazun te ta, ũ te óg blé glé téle mũ, longe POSP 3PP empurrar Espec 3PSM outro Espec 3PP POSP dançar descer PERF óg glé le jãgló, óg dun, óg mã mõ: ãg jyjy vũ Dãnlám ge 3PP dançar descer nisso 3PP POSP 3PP ouvir POSP 1PP nome MS outro grupo PROSP tẽ! ãg jyjy vũ Dantug ge tẽ!, ge óg mã̃ mõ mũ, IMPERF 1PP nome MS outro grupo PROSP IMPERF PROSP 3PP ouvir POSP PERF jãgló óg kagkómõ, óg mõ to vẽ mã ka glé kale mũ, glé mas 3PP nem ligar 3PP POSP POSP falar ouvir POSP dançar descer PERF dançar glé le jã, klẽ juggug jó klã kónhgág vágzul te ki dançar descer estar montanha gavião RETROS embaixo homem monte Espec POSP kale mũ, ki kale jãgló mẽ kónhgág tõ, klẽ juggug te descer PERF POSP descer nisso por ali homem TRANS montanha gavião Espec klãm, óg jágmẽn te vãnhmẽ tógzãg hũ mẽ tóg ké embaixo 3PP caminhos (pl) Espec Refl encruzilhada CJ por tudo DEMON agora 
katéle

descer

'então ao ver foram descendo, quando estava indo festejando pelo caminho, havia caminho dos 'dãnlám' atraz do caminho deles e eles vieram festejando pelo caminho e alcançaram eles, ao alcançar perguntaram dizendo: que homens são vocês? ele [Txu Txuvanh] falou para eles, mas ao ouvir, eles ficaram olhando para eles sem responder, ao ver que estavam lhe humilhando por não responder a pergunta, ficou brabo com eles e empurrou fora do caminho e desceu com os outros festejando pelo caminho, quando eles estava indo festejando pelo caminho, disseram atrás deles: nosso nome é dãnláim, nosso nome é dantug! disseram, mas eles não deram importância e continuaram descendo festejando, foram festejando até que chegara ali debaixo da montanha dos gaviões a onde estavam os homens, quando chegaram ali, tinha muito caminho dos homens que estavam todas encruzilhada uma na outra'

kũ ta klẽ juggug te klãm, âmen tógzãg te ka

Cj 3PSM montanha gavião Espec embaixo caminho encruzilhada Espec POSP óg blé glé nẽ kégke mũ, klẽ juggug te klãm kónhgág 3PP POSP dançar estar HAB PERF montanha gavião Espec embaixo homem vãgzul te ki óg kãgge mũ jãgló, tóg ké, klẽ juggug jó monte Espec POSP 3PP entrar PERF nisso DEMON gora montanha gavião RETROS klãm kónhgág vãgzul tõ võjõ tá blé kól jó ve kũ embaixo homem monte TRANS por nada mulher POSP pronto RETROS ver $\mathrm{Cj}$ to jũ mũ POSP brabo PERF

'então ele [Txu Txuvanh] ficou festejando [dançando] com os outros [parentes] ali de baixo da montanha dos gaviões, quando chegaram ali debaixo da montanha dos gaviões, todos os homens que estavam ali tinha fugido [pecado] com todas as mulheres que estavam ali, ao ver ele ficou muito [furioso] brabo'

ẽ tõ to jũ te kũ ta, klẽ juggug jó klãm CORR TRANS POSP brabo Espec CJ 3PSM montanha gavião RETROS embaixo kónhgág vãgzul te to ka glé nẽ, glé ta to jũ nẽ, homem monte Espec POSP POSP dançar estar dançar 3PSM POSP brabo estar 
kũ ta mẽ óg jé kyl nẽ kégke mũ. glé jã kũ ta: vãgdjó $\mathrm{Cj}$ 3PSM por tudo 3PP POSP gritar estar HAB PERF dançar estar Cj 3PSM chefe vãgdjó tõ Txu tõ Txuvanh! vãtxõ mã katél! huli nẽ, klẽ chefe TRANS nom. masc TRANS nom.masc Refl 2P descer agora estar montanha juggug jógklãm kónhgág vãgzul te mẽ nẽ, kujũn blé võjõ gavião embaixo homem monte Espec por tudo estar mulher POSP por nada kágkól jãg! kũ nũ klãm txã le jó nẽm jé txul nẽ!, acabar agora $\mathrm{Cj}$ 1P embaixo guerra descer RETROS deixar POSP querer deixar ke ta ti mõ mũ PROSP 3PSM 3PSM POSP PERF

'ao ficar brabo, ele ficou festejando [dançando] ali no meio debaixo da montanha dos gaviões, brabo mas festejando ali, ficava chamando outros amigos, dançando ele disse: chefe Txu Txuvanh! venha até aqui! porque aqui de baixo da montanha dos gaviões todos os homens fugiram [pecaram] com todas as mulheres daqui! ao ver isso estou querendo fazer uma destruição aqui [de baixo da montanha dos gaviões], falou ele'

ẽ tõ to jũ jé txul kũ ti tõ, ti jé kyl nẽ CORR TRANS POSP brabo POSP querer Cj 3PSM TRANS 3PSM POSP gritar estar vã, kũ ta vel ũ jé kyl kégke jã: vãgdjó tõ Vãjẽky, ESTAT Cj 3PSM de novo outro POSP gritar HAB estar chefe TRANS nom. masc vãtxõ mã katéle! Huli nẽ, klẽ juggug jógklãm kónhgág vãgzul te Refl 2P descer agora estar montanha gavião embaixo homem monte Espec mẽ nẽ, kujũn blé võjõ kágkól jãg! kũ nũ klã̃ txã le por tudo estar mulher POSP por nada acabar estão $\mathrm{Cj} 1 \mathrm{P}$ embaixo guerra descer jó nẽm jé txul nẽ! kũ nũ a jé avanh nẽ!", ke ta RETROS deixar POSP querer deixar Cj 1P 2P POSP esperar estar PROSP 3PSM ti mõ mũ 3PSM POSP PERF

'ele queria guerrear por isso ele estava chamando as pessoas, ficava chamando alguém, até que ele falou: chefe Vãjẽky, venha aqui, porque aqui de baixo da montanha dos gaviões os homens fugiram [pecaram] todos com as mulheres! por isso quero fazer uma guerra aqui, e eu estou esperando você aqui, disse' 
ẽ tõ to jũ jé txul kũ ti tõ mẽ óg vãgzun

CORR TRANS POSP brabo POSP querer Cj 3PSM TRANS por tudo 3PP convocar ha vã, kũ ta, óg jé kyl kũ ka glé nẽ kégke mũ, jãgló ENF ESTAT Cj 3PSM 3PP POSP gritar Cj POSP dançar estar HAB PERF nisso vãgdjó tõ Txu tõ Txuvanh te katéle mũ, ẽ katéle te chefe TRANS nom. masc TRANS nom. masc Espec descer PERF CORR descer Espec kũ ta, kujũn blé vãjõ kágkól jó te ve kũ, ẽ tõ to CJ 3PSM mulher POSP por nada acabar RETROS Espec ver Cj CORR TRANS POSP jũ kũ tẽg jé txul nĩ ke jã, ta tẽ mũ babo $\mathrm{Cj}$ ir POSP querer está PROSP estar 3PSM ir PERF

'ele queria fazer uma guerra por isso que estava ajuntando as pessoas, ele ficava chamando as pessoas, nisso o chefe Txu Txuvanh veio atrás dele, quando ele chegou ao ver que os homens tinha fugido [pecado] com as mulheres ficou muito furioso e queria voltar de volta até foi embora'

ẽ tẽg kũ ta óg mõ: vãha nũ ké ló, a tõ gó tóg CORR ir Cj 3PSM 3PP POSP agora $1 \mathrm{P}$ agora POSP 2P TRANS terra DEMON mẽ vãtxõ kónhgág kugmãn kũ nũ, a du a nẽvigkugkén jé katéle-hó por tudo Refl homem negar Cj 1P 2P POSP 2P destruir POSP descer ke ta mũ, ẽ tõ like kól te kũ ta tẽ mũ PROSP 3PSM PERF CORR TRANS POSP depois Espec Cj 3PSM IMPERF PERF

'quando ele estava indo falou para eles: agora por vocês terem humilhado [constrangidos] os homens, eu vou voltar para destruir vocês, depois de falar isso ele foi embora'

kũ ta, ti tẽg te ve kũ vel vãtxika vãgdjó tõ Vãjẽky $\mathrm{Cj}$ 3PSM 3PSM ir Espec ver $\mathrm{Cj}$ de novo novamente chefe TRANS nom. masc te jé kyl ban mũ: Vãgdjó tõ Vãjẽky, vãtxõ mã katéle! Espec POSP gritar novamente PERF chefe TRANS nom. masc Refl 2P descer Huli nẽ, klẽ juggug jógklãm kónhgág vãgzul te mẽ nẽ, agora estar montanha gavião embaixo homem monte Espec por tudo estar kujũn blé võjõ kágkól jãg! kũ nũ klã txã le jó nẽm mulher POSP por nada acabar agora $\mathrm{Cj} 1 \mathrm{P}$ embaixo guerra descer RETROS deixar 
jé txul nẽ! kũ nũ vãnhgéj jé a jé avanh nẽ! ke ta mũ POSP querer estar! Cj $\mathrm{P}$ guerra POSP 2P POSP esperar estar PROSP 3PSM PERF

'ao ver ele indo embora, ele chamou novamente o chefe Vãjẽky dizendo: chefe Vãjẽky venha aqui! porque aqui de baixo da montanha dos gaviões todos os homens já fugiram [pecaram] com as mulheres! por isso estou querendo fazer uma guerra aqui! por isso estou lhe esperando para iniciar esta guerra! falou ele'

mũ jãgló mã kũ, vãgdjó tõ Vãjẽky te katéle mũ, ẽ katéle te PERF mas $2 \mathrm{P} \mathrm{Cj}$ chefe TRANS nom. masc Espec descer PERF CORR descer Espec kũ ta klẽ juggug jógklã̃ kónhgág vãgzul te ki, óg tõ Cj 3PSM montanha gavião embaixo homem monte Espec POSP 3PP TRANS tá blé jãgnõ jó te ve kũ, ẽ tõ to jũ kũ tẽg jé mulher POSP deitar RETROS Espec ver $\mathrm{Cj}$ CORR TRANS POSP brabo $\mathrm{Cj}$ ir POSP txul nĩ kégke mũ querer estar HAB PERF

'nisso ao ouvir isso, o chefe Vãjẽky desceu atrás dele, quando ele chegou ali embaixo da montanha dos gaviões a onde tinha bastante homens mas, eles já tinha fugidos com as mulheres, ao ver isso ele ficou furioso e queria embora até foi embora'

ẽ tẽg kũ Vãjẽky te óg mõ: vãha nũ ké ló, a tõ gó CORR ir $\mathrm{Cj}$ nom. masc Espec 3PP POSP agora $1 \mathrm{P}$ agora POSP 2P TRANS terra tóg mẽ vãtxõ kónhgág kugmãn kũ nũ, a du a pipin tẽn jé DEMON por tudo Refl homem negar Cj 1P 2P POSP 2P espalhar fazer POSP katéle-hó! ke ta mũ, like kól kũ ta tẽ mũ descer PROSP 3PSM PERF POSP depois Cj 3PSM ir PERF

'quando estava indo Vãjẽky disse para eles: agora por vocês terem me humilhado [constrangidos], eu vou, mas eu volto para destruir vocês! depois que falou isso ele foi embora'

ti tẽg te ve kũ ta ka glé jã kũ,óg jé kyl jã kégke 3PSM ir Espec ver Cj 3PSM POSP dançar estar Cj 3PP POSP gritar estar HAB 
mũ, glé jã jã ta: Vãgdjó tõ Gojtxá tõ Jahá! vãtxõ PERF dançar estar estar 3PSM chefe TRANS nom. masc TRANS nom. masc Refl mã̃ katéle! Huli nẽ, klẽ juggug jógklãm kónhgág vãgzul te mẽ 2P descer agora estar cabeça gavião embaixo homem monte Espec por tudo nẽ, kujũn blé võjõ kágkól jãg! kũ nũ klã̃ txã le jó estar mulher POSP por nada acabar agora $\mathrm{Cj} 1 \mathrm{P}$ embaixo guerra descer RETROS nẽm jé txul nẽ! kũ nũ vãnhgéj jé a jé avanh nẽ! ke deixar POSP querer estar $\mathrm{Cj} 1 \mathrm{P}$ guerra POSP 2P POSP esperar estar PROSP ta mũ

\section{PSM PERF}

'ao ver ele embora ele ficou ali festejando [dançando] e ficava chamando os outros, festando e disse: chefe Gojtxá Jahá! venha até aqui! porque aqui de baixo da montanha dos gaviões a onde tem bastante homens, todos eles fugiram com as mulheres! por isso quero fazer uma guerra aqui e eu estou esperando você aqui, disse ele'

ti tõ like jã jãgló, vãgdjó tõ Gojtxá tõ Jahá te 3PSM TRANS POSP estar nisso chefe TRANS nom. masc TRANS nom. masc Espec katéle mũ, ẽ katéle te kũ ta, klé juggug jógklã̃ kónhgág descer PERF CORR descer Espec Cj 3PSM montanha gavião embaixo homem vãgzul te ki, óg tõ tá blé kágkól jó te ve kũ, ẽ monte Espec POSP 3PP TRANS mulher POSP acabar RETROS Espec ver Cj CORR tõ to jũ kũ tẽg jé txul nĩ kégke mũ TRANS POSP brabo $\mathrm{Cj}$ ir POSP querer estar HAB PERF

'quando ele estava falando isso, o chefe Gojtxá Jahá desceu atrás dele, quando ele desceu até ali, ele vi que de baixo da montanha gavião onde tinha bastante homens, ele viu que eles tinha fugido com as mulheres e ficou furioso e queria ir de volta até que ele foi de volta'

ẽ tõ to jũ kũ, tẽg txul nẽ ke jã ta ẽ tẽg kũ: CORR TRANS POSP brabo $\mathrm{Cj}$ ir querer estar PROSP estar 3PSM CORR ir $\mathrm{Cj}$ vãha nũ ké ló, a tõ gó tóg mẽ vãtxõ kónhgág kugmãn agora 1P agora POSP 2P TRANS terra DEMON por tudo Refl homem negar mũ ló nũ, a du a nẽvigkugkén jé katéle tẽ! vãha nũ ké ló, a 
PERF POSP 1P 2P POSP 2P destruir POSP descer PERF agora 1P agora POSP 2P tõ gó tóg mẽ vãtxõ kónhgág kugmãn kũ nũ, a du a pipin CORR terra DEMON por tudo Refl homem negar Cj $1 \mathrm{P} 2 \mathrm{P}$ POSP 2P espalhar tẽn jé katéle tẽ!", ke ta mũ fazer POSP descer IMPERF PROSP 3PSM PERF

'ficou furioso e quando estava indo de volta ele falou: agora por vocês terem me humilhado [constrangidos], eu vou voltar para destruir vocês! por vocês terem desobedecido as leis daqui desta terra voltarei para acabar com todos vocês! falou isse e foi embora’

jãgló vãgdjó tõ Txu tõ Txuvanh te tõ, ẽ tõ nisso chefe TRANS nom. masc TRANS nom. masc Espec TRANS CORRR TRANS to jũ te kũ klẽ juggug jógklãm kónhgág vãgzul te ki, POSP brabo Espec Cj montanha gavião embaixo homem monte Espec POSP txã le jó tõ ka nẽm jé txul vã guerra descer RETROS TRANS POSP deixar POSP querer ESTAT

'mas o chefe Txu Txuvanh estava furioso e queria fazer guerra ali de baixo da montanha gavião a onde tinha bastante homens'

kũ ta, ti tẽg te ve kũ, ka glé jã ke jã ta vel:

Cj 3PSM 3PSM ir Espec ver Cj POSP dançar estar PROSP estar 3PSM de novo vãgdjó tõ Kóza! vãtxõ mã katéle! Huli nẽ, klẽ juggug jógklãm chefe TRANS nom. masc Refl 2P descer agora estar montanha gavião embaixo kónhgág vãgzul te mẽ nẽ, kujũn blé võjõ kágkól jãg! homem monte Espec por tudo estar mulher POSP por nada acabar agora kũ nũ klã txã le jó nẽm jé txul nẽ! kũ nũ vãnhgéj $\mathrm{Cj} 1 \mathrm{P}$ embaixo guerra descer RETROS deixar POSP querer estar $\mathrm{Cj} 1 \mathrm{P}$ guerra a jé avanh nẽ!, ke ta mũ 2P POSP esperar estar PROSP 3PSM PERF

'ao ver ele indo embora ele ficou ali festejando até que falou: chefe Kóza! venha [logo] aqui! porque aqui de baixo da montanha gavião a onde tem bastante homens, eis que todos eles 
fugiram com as mulheres daqui! por isso estou querendo fazer guerra aqui! estou esperando você para fazermos guerra junto! disse ele'

ẽ tõ like kól te kũ ta ti jé avanh nẽ jãgló, vãgdjó CORR TRANS POSP depois Espec Cj 3PSM 3PSM POSP esperar estar mas chefe tõ Kóza te, ti du katéle tavig mũ, ti tavi ló, TRANS nom. masc Espec 3PSM POSP descer chegar PERF 3PSM chegar POSP klẽ juggug jógklã kónhgág vãgzul te mẽ, óg tõ tá montanha gavião embaixo homem monte Espec por tudo 3PSM TRANS mulher blé nõ kól jó tẽ, kũ ta, ẽ tõ ve te kũ to jũ POSP estão depois RETROS ir Cj 3PSM CORR TRANS ver Espec Cj POSP brabo kũ tẽg txul nẽ jã ta tẽ mũ $\mathrm{Cj}$ ir querer estar estar 3PSM ir PERF

'depois que ele falou, ficou esperando ele, nisso o chefe Kóza veio atrás dele e chegou ali, quando ele chegou viu que realmente de baixo da montanha gavião a onde tinha bastante homens, todos tinha fugido com as mulheres, ao ver ele ficou furioso e queria ir de volta até que ele foi embora'

ẽ tẽg kũ ta óg mõ: vãha nũ ké ló, a tõ gó tóg CORR ir Cj 3PSM 3PP POSP agora 1P agora POSP 2P TRANS terra DEMON mẽ vãtxõ kónhgág kugmãn mũ ló nũ, a du a nẽvigkugkén jé por tudo Refl homem negar ir POSP 1P 2P POSP 2P destruir POSP katéle tẽ! vãha nũ ké ló, a tõ gó tóg mẽ vãtxõ descer IMPERF agora 1P agora POSP 2P TRANS terra DEMON por tudo Refl kónhgág kugmãn kũ nũ, a du a pipin tẽn jé katéle tẽ!, ke homem negar $\mathrm{Cj} \quad 1 \mathrm{P}$ 2P POSP 2P espalhar fazer POSP descer IMPERF PROSP ta mũ 3PSM PERF

'quando estava indo falou para ele: agora por vocês terem me humilhado [constrangidos], eu vou voltar para destruir vocês! por vocês terem desobedecido as leis daqui desta terra voltarei para acabar com todos vocês! falou isse e foi embora' 
like jã ta vãha Kóza te tẽ mũ, ti tẽg kól te kũ, POSP estar 3PSM agora nom. masc Espec ir PERF 3PSM ir depois Espec CJ Txu te ka glé jã kégke mũ, jãgló vãgdjó tõ Kóza nom. masc Espec POSP dançar estar HAB PERF nisso chefe TRANS nom. masc te ẽ tẽg te kũ ta vãtxika, klẽ juggug jógklãm kónhgág Espec CORR ir Espec Cj 3PSM de volta montanha gavião embaixo homem vãgzul te ki, txã le jó tõ ka nẽm jé katéle mũ monte Espec POSP tucano descer RETROS TRANS POSP deixar POSP descer PERF

'depois que falou isso o [chefe] Kóza foi embora, depois que ele foi embora o Txu ficou ali no mesmo lugar festejando, enquanto isso o chefe Kóza voltou para destruir aqueles homens que estava transgredindo as leis que estava ali de baixo da montanha dos gaviões'

kũ ta tóg ké mẽ óg pipin mũ, ũn tõ kujõn blé Cj 3PSM DEMON agora por tudo 3PP espalhar PERF quem TRANS mulher POSP nõ mũ te óg, ti tõ ẽ pipin te kũ, kózéj te ló estar ir Espec 3PP 3PSM TRANS CORR espalhar Espec $\mathrm{Cj}$ mato Espec POSP mẽ ge mũ, óg mũ kũ vég te, Txu tõ Txuvanh te por tudo assim ir $3 \mathrm{PP}$ ir $\mathrm{Cj}$ ver Espec nom. masc TRANS nom. masc Espec vel ta zóklãl te ki la mũ de novo 3PSM embaixo Espec POSP entrar PERF

'então ele destruíu e assim se espalharam, aqueles que tinha pecado com as mulheres, quando ele destruiu eles [pouquinho] foram entrar novamente para o mato, assim o chefe Txu Txuvanh também entrou novamente para o mato'

ẽ tõ zóklãl ki la te kũ ta, ka glé jã kégke jã, a CORR TRANS mato POSP entrar Espec Cj 3PSM POSP dançar estar HAB estar 2P ki ta, mõg junhklél han mũ, ẽ tõ mõg junhklél han te POSP 3PSM bebida azeda fazer PERF CORR TRANS bebida azeda fazer Espec kũ ta, klẽ óg blé glé jã ta, ẽ kónhka há tõ Txu Cj 3PSM encima 3PP POSP dançar estar 3PSM CORR parente bem CORR nom. masc tõ Txuvanh jé kyl mũ TRANS nom. masc POSP gritar PERF 
'quando ele entrou no mato, ele ficou lá festejando, ali mesmo ele preparou um 'mõg' [bebida tradicional], quando ele fez o 'mõg' ele ficou ali perto festejando com os outros [parente], ele ficou chamando seu parente Txu Txuvanh'

ti jé kyl kũ ta: vãgdjó tõ Txu tõ Txuvanh! vãtxõ 3PSM POSP gritar Cj 3PSM chefe TRANS nom. masc TRANS nom. masc Refl mã katéle! Huli nẽ, klẽ juggug jó klãm Kóza nẽ, txã 2P descer agora estar montanha gavião POSP embaixo nom. masc estar guerra le jó nẽm kũ, kónhgág pipin tẽn jó ha ka ẽnh glé jãg descer POSP deixar $\mathrm{Cj}$ homem espalhar fazer POSP ENF POSP 1P dançar estar ha vũ ki jã!", ke ta mũ ENF MS POSP estar PROSP 3PSM PERF

'chamando ele e disse: chefe Txu Txuvanh! venha novamente até aqui! porque aqui de baixo da montanha dos gaviões [chefe] Kóza fez guerra e os homens se espalharam todos entraram para mato, e eu estou aqui sozinho festejando! disse ele'

ẽ tõ like kól te kũ ta, ti jé avanh nẽ jãgló, CORR TRANS POSP acabar Espec Cj 3PSM 3PSM POSP olhar estar nisso vãgdjó tõ Txu tõ Txuvanh te, ti du katéle chefe TRANS nom. masc TRANS nom. masc Espec 3PSM POSP descer tavig mũ, kũ ta, ti katéle te kũ ti mõ: vãgdjó tõ Txu chegar PERF Cj 3PSM descer Espe CJ 3PSM POSP chefe TRANS nom. masc tõ Txuvanh! Huli nẽ, klẽ juggug jó klãm kónhgág vãgzul TRANS nom. mas agora estar montanha gavião POSP embaixo homem monte te ka vãgdjó tõ Kóza vũ txã le jó nẽm kũ, Espec POSP chefe TRANS nom. masc MS guerra descer POSP deixar Cj kónhgág pipin tẽn mũ! kũ ẽ txõ zóklãl ki la jó ha homem espalhar fazer PERF Cj CORR TRANS mato POSP entrar POSP ENF ka ẽnh glé jãg ha vũ ki jã!, ke ta mũ POSP 1P dançar estar ENF MS POSP esta PROSP 3PSM PERF

'depois que ele falou isso, ficou esperando ele e nisso o chefe Txu Txuvanh veio atrás dele novamente, quando ele chegou ele disse para ele: chefe Txu Txuvanh aqui de baixo da 
montanha dos gaviões onde tinha bastante homens o chefe Kóza destruíu eles e eu assim entrei novamente para mato e eu estou aqui sozinho festejando, disse ele'

kũ ta mãg kũ, tẽg txul jã jã ta, vãtxika tẽ mũ kũ ta

$\mathrm{Cj}$ 3PSM ouvir $\mathrm{Cj}$ ir querer estar estar 3PSM de volta ir PERF Cj 3PSM vel, vãgdjó tõ Vãjẽky jé kyl nẽ kégke mũ, vãgdjó de novo chefe TRANS nom. masc POSP gritar estar HAB PERF chefe tõ Vãjẽky tõ Jahá! vãtxõ mã katéle! Huli nẽ klẽ TRANS nom. masc TRANS nom. masc Refl 2P descer agora estar montanha juggug jógklãm kónhgág vãgzul te mẽ nẽ, kujũn blé võjõ gavião embaixo homem monte Espec por tudo estar mulher POSP por nada kól jãg! Huli nẽ Kóza vũ ka txã le jó nẽm kũ acabar estar agora estar nom. masc MS POSP guerra descer POSP deixar $\mathrm{Cj}$ kónhgág te vũ pipin tẽn mũ! kũ ẽ txõ, zóklãl ki la homem Espec MS espalhar fazer PERF $\mathrm{Cj}$ CORR TRANS mato POSP entrar ja ha ka nũ ki jã!, ke ta ti mõ mũ onde ENF POSP 1P POSP estar PROSP 3PSM 3PSM POSP PERF

'ao ouvir isso, ele queria voltar até que ele foi embora, e ao ver ele ir embora, chamou o chefe Vãjẽky e disse: chefe Vãjẽky Jahá! venha aqui de pressa! porque aqui de baixo da montanha dos gaviões onde tinha bastante homens, todos fugiram com as mulheres! Por isso o chefe Kóza os destruiu e os homens se espalharam todos! e eu entrei novamente para o mato e por isso estou aqui ainda! disse para ele'

mã kũ ta, ẽ tẽg jé txul jã jã ta vãtxika tẽ mũ ouvir Cj 3PSM CORR ir POSP querer estar estar 3PSM de novo ir PERF kũ ta ve kũ, ẽ txõ mõg junhklé te kagklan jé txul kũ $\mathrm{Cj}$ 3PSM ver $\mathrm{Cj}$ CORR TRANS bebida azeda Espec beber POSP querer $\mathrm{Cj}$ ta ka glé jã, dén tõ ẽ tõ ẽ txy kózan 3PSM POSP dançar estar algo TRANS CORR TRANS CORRR chocalho enfeitar jé txul kũ ta ka glé jã POSP querer Cj 3PSM POSP dançar estar 
'ao ouvir isso ele queria ir de volta até que ele foi ao ver isso ele queria tomar seu 'mõg junhklé' [bebida tradicional a base de mel] e ficou ali festejando, porque ele queria algo para decorar seu chocalho'

ka ta glé jã jã ta, txã pénũg mũ, vãgdjó te ẽ POSP 3PSM dançar estar estar 3PSM tucano acertar/matar PERF chefe Espec tõ txã pénũ ti klum jó ha tõ ta, ẽ txy TRANS tucano acertar/matar 3PSM pena RETROS ENF TRANS 3PSM CORR chocalho te kózan mũ, ẽ tõ ẽ txy kózan jé txul nẽ kégke Espec enfeitar PERF CORR TRANS CORR chocalho enfeitar POSP querer estar HAB mũ te ta, ẽ tõ txã pénũ ti klum jó tõ PERF Espec 3PSM CORR TRANS tucano atirar/matar 3PSM pena RETROS TRANS lén mũ enfeitar PERF

'ficou ali festejando até que ele matou um 'txã', o chefe pegou a pena colorida do 'txã' que ele matou para decorar seu chocalho [instrumento musical], pois já era tempo que estava querendo decorar seu chocalho mas finalmente conseguiu com a pena colorida do 'txã' que ele matou'

kũ ta vãha kulõ to te mẽ glé katéle mũ, kulõ to Cj 3PSM agora campo POSP Espec por ali dançar descer PERF campo POSP te ka glé jã jã ta, óg mõ: vãtxõ jé ẽnh kónhka há tõ Espec ali dançar estar estar 3PSM 3PP POSP Refl POSP 1P parente bem TRANS Gojtxá tõ Jahá tẽg jó ẽ txõ vég ló, gó tóg nom. masc TRANS nom. masc ir RETROS CORR TRANS ver POSP terra DEMON te mẽ ẽnh jé kóty tẽ jé!, ke mũ Espec por ali 1P POSP vazio IMPERF POSP PROSP PERF

'agora ele veio festejando pelo meio do campo, veio festejando pelo meio do campo até que ele falou: se eu estivesse visto para onde foi meu irmão Gojtxá Jahá eu não estaria mais nesta terra, falou ele' 
tóg ké vãha ti kógtãm ha vã, kũ ta vãha ha ki DEMON agora agora 3PSM final ENF ESTAT Cj 3PSM agora ali POSP hum ke mũ, tóg ge kũ ta hun kégke mũ parar PROSP PERF DEMON assim CJ 3PSM parar HAB PERF

'assim termina, então parou ali, agora chegou o fim. 